\author{
UNIVERSIDADE DE SÃO PAULO \\ ESCOLA DE COMUNICAÇÃO E ARTES \\ PROGRAMA DE PÓS-GRADUAÇÃO EM CIÊNCIAS DA COMUNICAÇÃO
}

\title{
O DISCURSO AUTOBIOGRÁFICO NOS QUADRINHOS: \\ UMA ARQUEOLOGIA DO EU NA OBRA \\ DE ROBERT CRUMB E ANGELI
}

Juscelino Neco de Souza Júnior

São Paulo, Dezembro de 2014 


\author{
UNIVERSIDADE DE SÃO PAULO \\ ESCOLA DE COMUNICAÇÃO E ARTES \\ PROGRAMA DE PÓS-GRADUAÇÃO EM CIÊNCIAS DA COMUNICAÇÃO
}

\title{
O discurso autobiográfico no quadrinhos: uma arqueologia do eu na obra de Robert Crumb e Angeli
}

Juscelino Neco de Souza Júnior

Tese apresentada à Escola de Comunicação em Artes da Universidade de São Paulo, para a obtenção do título de Doutor em Ciências da Comunicação, Área Temática Interfaces Sociais da Comunicação, sob orientação do Prof. Dr. Waldomiro de Castro Santos Vergueiro.

São Paulo, Dezembro de 2014 


\section{Banca Examinadora:}

Nome do autor:

Título da Tese:

Presidente da Banca: Prof. Dr.

Banca Examinadora:

Prof. Dr. Instituição:

Prof. Dr. Instituição:

Prof. Dr. Instituição:

Prof. Dr. Instituição:

Prof. Dr. Instituição:

Aprovada em: I 
Comics are words and pictures. You can do anything with words and pictures.

Harvey Pekar 
Pra Camila, como todo o resto. 


\section{AGRADECIMENTOS}

Ao Prof. Waldomiro Vergueiro, pela generosidade intelectual e paciência.

À minha mãe, que nunca jogou fora meus gibis.

Ao Cledson, pelas muitas transcrições.

À FAPESP, pelo bolsa de estudos que me permitiu desenvolver essa pesquisa nas melhores condições possíveis.

À comunidade de scans brasileira e norte-americana, que facilitou meu acesso a diversas publicações raras. 


\section{RESUMO}

Investigação sobre o discurso da autobiografia em quadrinhos desenvolvida nos Estados Unidos e Brasil, concentrada, principalmente, na obra de Robert Crumb e Angeli. Seguindo a primeira fase do método arqueológico e a teoria do discurso definida por Michel Foucault, a tese se empenha em determinar as condições históricas de possibilidade desse discurso e em efetuar uma análise formal desses objetos materiais. Para tanto, alia-se diversas proposições teóricas advindas do campo da autobiografia, arte, cinema, jornalismo e quadrinhos.

Palavras-chave: Autobiografia em quadrinhos; Robert Crumb; Angeli; Michel Foucault. 


\begin{abstract}
Research about the discourse of the autobiographical comics created in United States and Brazil, mainly focusing on the works by Robert Crumb and Angeli. Following the first stage of the archaeological description and Michel Foucault's discourse theories, the thesis engages in determining the historical conditions that made this discourse possible and perform a formal analysis of their materials objects. For this purpose, theoretical propositions from different academic fields as autobiography, art, cinema, journalism and comic books are put together.
\end{abstract}

Key-words: autobiographical comics; Robert Crumb; Angeli; Michel Foucault. 


\section{LISTA DE FIGURAS}

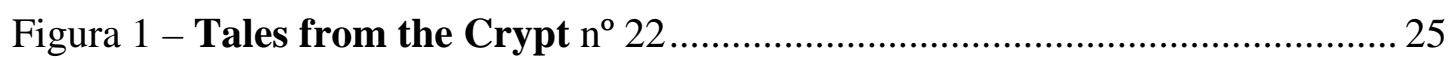

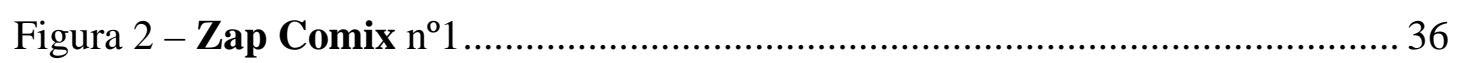

Figura 3 - Binky Brown, de Justin Green ........................................................... 43

Figura 4 - Primeira versão de Maus, de Art Spiegelman ........................................... 46

Figura 5 - Prisioner on the Hell Planet, de Art Spiegelman...................................... 47

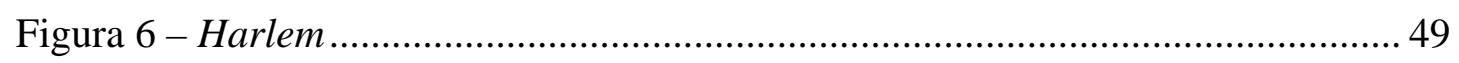

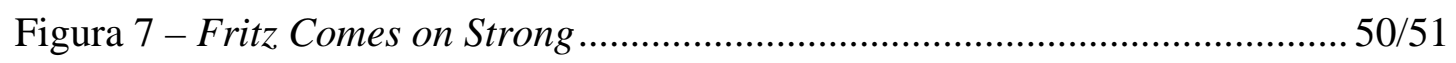

Figura 8 - R. Crumb Comics and Stories ............................................................ 55

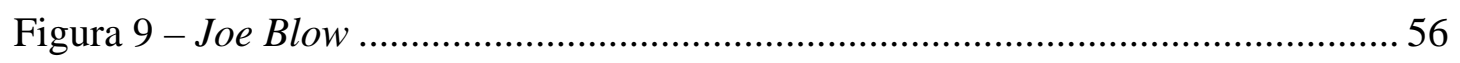

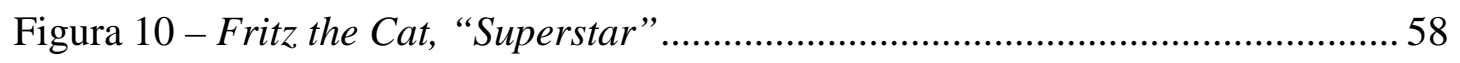

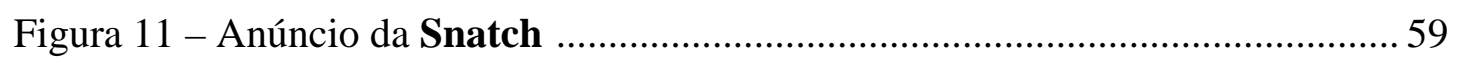

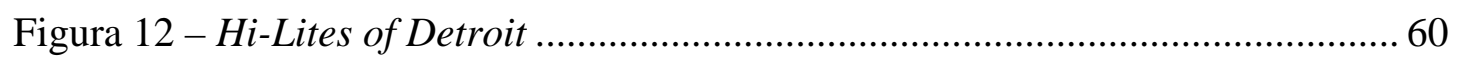

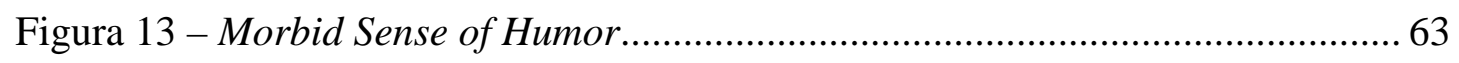

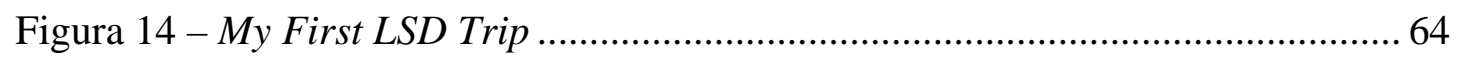

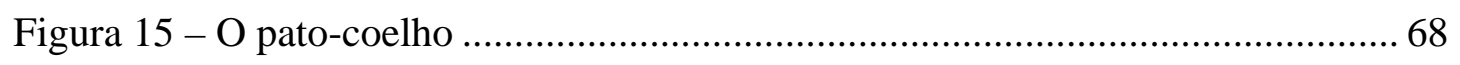

Figura 16 - Crônicas de Jerusalém, de Guy Delisle ................................................ 71

Figura 17 - Mr. Natural e Flakey Foont in “A Gurl in Hotpants” (1971)................. 72

Figura 18 - The adventures of Robert Crumb Himself (1973) .................................. 73

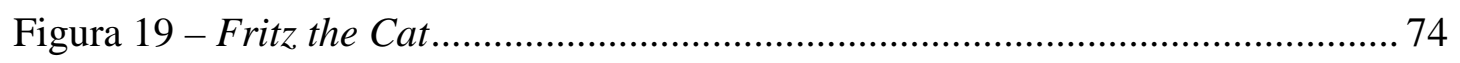

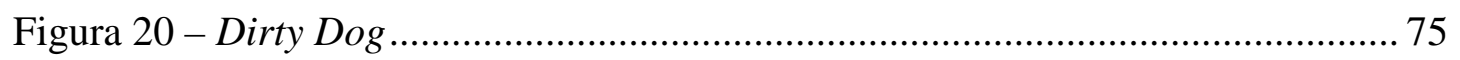

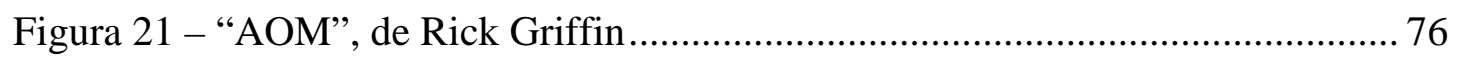

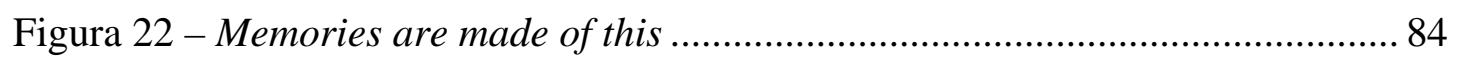

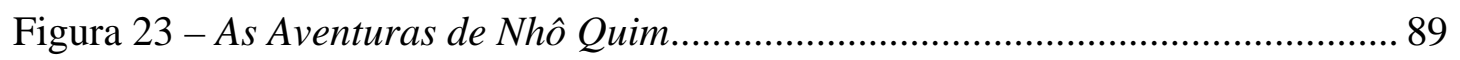

Figura 24 - Logotipo de O Tico-Tico ….................................................................. 90

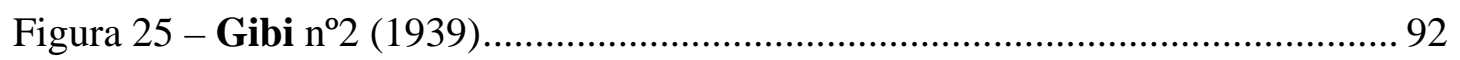

Figura 26 - Catecismo de Carlos Zéfiro ............................................................... 100

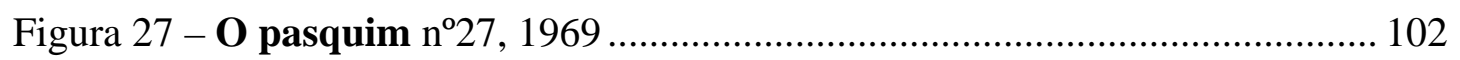

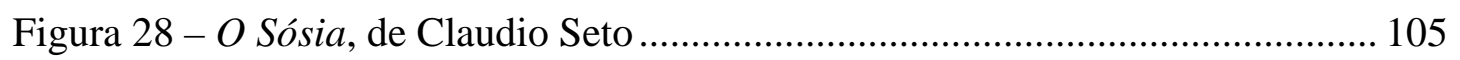

Figura 29 - O Sósia, de Claudio Seto ....................................................................... 106

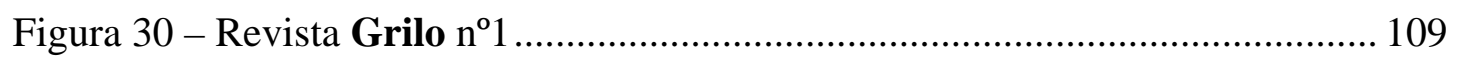

Figura 31 - Censura a Crumb na revista Grilo nº 32 .............................................. 112

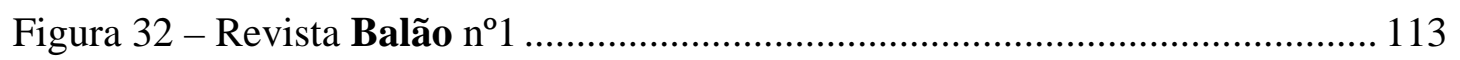

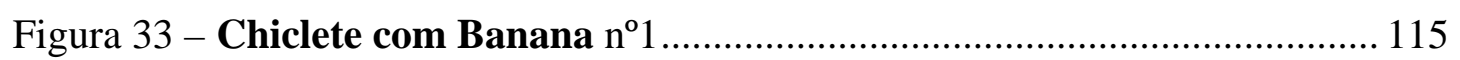

Figura 34 - Primeira versão da Chiclete com Banana .............................................. 120 
Figura 35 - Primeira tira Chiclete com Banana.

Figura 36 - Primeira aparição de Angeli na Chiclete com Banana .......................... 121

Figura 37 - Tira autobiográfica de Angeli

Figura 38 - Primeiras tiras da série Angeli em Crise.

$123 / 124$

Figura 39 - Suplemento JAM da Chiclete com Banana n ${ }^{\circ} 18$................................ 127

Figura 40 - Autorepresentação de Angeli .................................................................. 129

Figura 41 - Primeira publicação da série Angeli em Crise na revista ...................... 129

Figura 42 - Angeli em Crise na Chiclete com Banana nº 4 ...................................... 131

Figura 43 - Primeira história longa da série Angeli em Crise ................................. 132

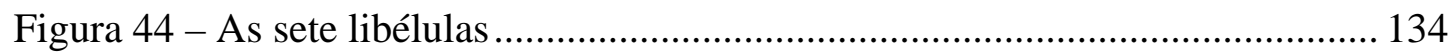

Figura 45 - "Que tudo mais vá pro inferno", de Angeli.......................................... 135

Figura 46 - Últimas tiras da série Angeli em Crise na Chiclete com Banana ........ 135

Figura 47 - Les poires, de Charles Philipon ............................................................ 139

Figura 48 - Caricatura do presidente Sarney ........................................................ 141

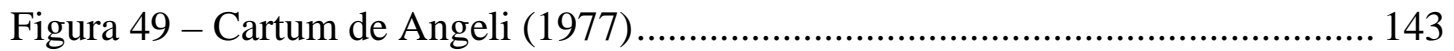

Figura 50 - Enquadramento nas primeiras obras de Angeli ................................... 144

Figura 51 - Enquadramentos da fase final da Chiclete com Banana...................... 145

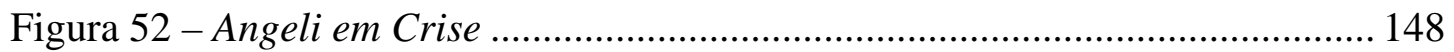

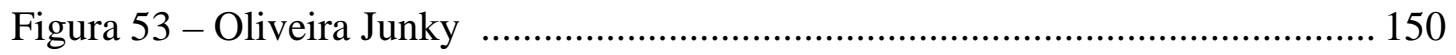

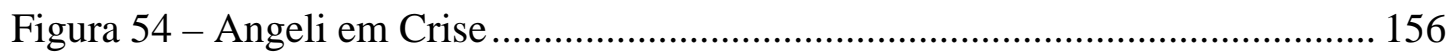

Figura 55 - Paying for it, de Chester Brown ........................................................ 167

Figura 56 - "Foda-se todo mundo aqui”, de Cynthia B.......................................... 168

Figura 57 - Preto no Branco, de Allan Sieber ............................................................ 169

Figura 58 - Maus, de Art Spiegelman ................................................................ 173

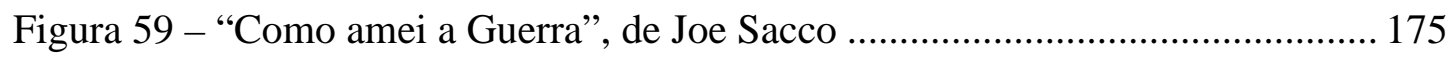

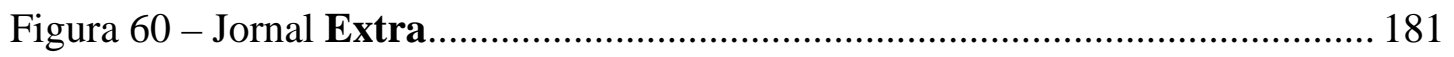




\section{SUMÁRIO}

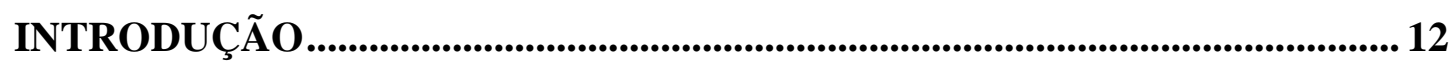

1 AUTOBIOGRAFIA EM QUADRINHOS NOS ESTADOS UNIDOS .............. 19

1.1 Do comic book ao Comics Code ....................................................................... 19

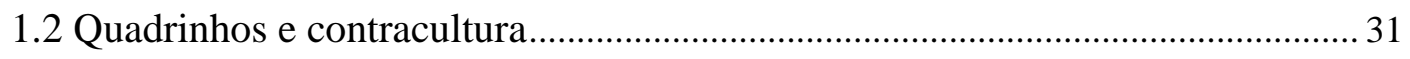

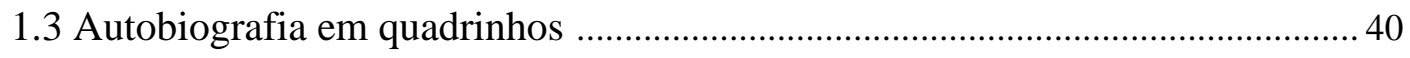

2 A ESTRUTURA DA AUTOBIOGRAFIA EM CRUMB ................................... 49

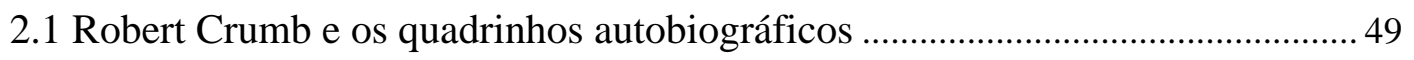

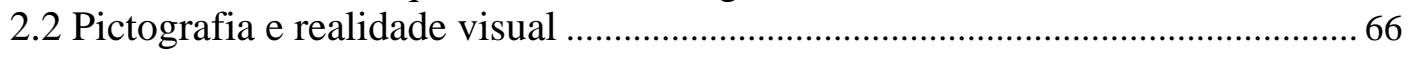

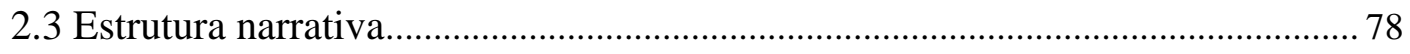

3 AS HISTÓRIAS EM QUADRINHOS NO BRASIL .............................................. 88

3.1 A formação do mercado editorial de quadrinhos no Brasil................................... 88

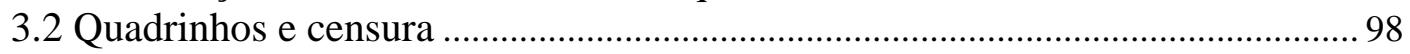

3.3 Da imprensa alternativa aos quadrinhos da Circo Editorial ................................ 108

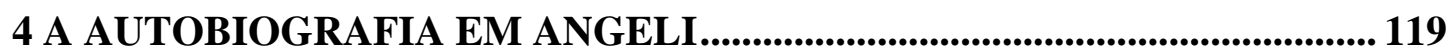

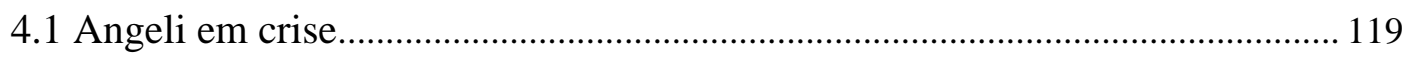

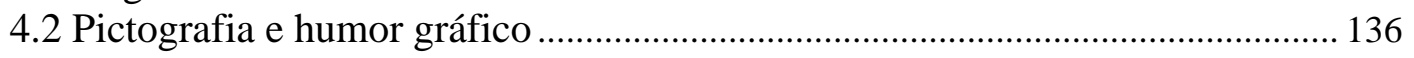

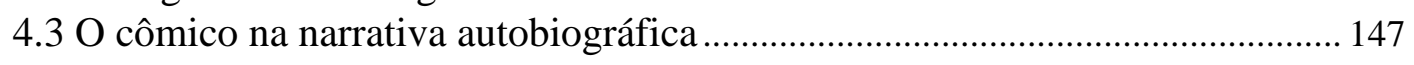

5 A MATRIZ AUTOBIOGRÁFICA.................................................................... 159

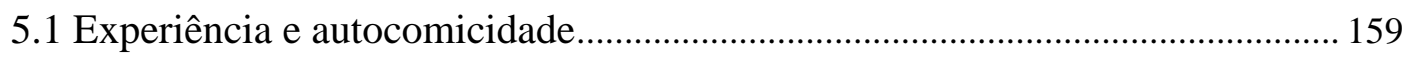

5.2 Autobiografia, biografia e jornalismo: derivação e resiliência............................ 171

CONSIDERAÇÕES FINAIS ................................................................................ 183

REFERÊNCIAS BIBLIOGRÁFICAS....................................................................... 191 


\section{INTRODUÇÃO}

O surgimento da autobiografia nos quadrinhos é um evento bastante singular, considerando o tipo de narrativa, a temática e os gêneros tradicionalmente associados a essa mídia. Uma análise superficial do tipo de publicação veiculado pela indústria pode ajudar a esclarecer porque o projeto da autobiografia se choca com o tradição das histórias em quadrinhos. Em primeiro lugar, elas normalmente constroem narrativas baseadas na exterioridade da ação, em que o enredo é conduzido numa série de eventos inter-relacionados que conduzem a trama para um desfecho. $\mathrm{Na}$ autobiografia acontece um deslocamento da ação para a vida interior da personagem, na qual seu fluxo de pensamentos, sensações, memórias e sentimentos ocupam a centralidade da narrativa. Assim, embora os quadrinhos autobiográficos representem pictograficamente uma série de atividades da vida comum, a ação interior/psicológica conduz a narrativa, muitas vezes enfraquecendo a enredo. Dito de outra forma, os quadrinhos tradicionais buscam construir narrativas baseadas na causalidade temporal, orientados em função da resolução da intriga e das convenções de cada gênero; enquanto que os quadrinhos autobiográficos concentram-se na vida interior, pautados nas experiências da personagem e não das necessidades do enredo.

Outro aspecto contraditório diz respeito à oposição entre a autobiografia e os temas comumente abordados pelas histórias em quadrinhos. Desde sua consolidação como mídia e linguagem, ocorrida durante as primeiras décadas do século XX, os quadrinhos já demonstravam sua vocação para o tratamento de categorias narrativas associadas com o humor e a aventura. Mesmo que abordassem relações familiares ou peripécias infantis, as primeiras séries não tratavam o cotidiano de forma referencial, concentrando-se justamente no absurdo das situações cômicas. Se considerarmos as séries de aventura e fantasia, comuns a partir da década de 1930, fica ainda claro o quanto os quadrinhos se interessam pelo que está além da experiência comum (WITEK, 1989, p.13). Em oposição a essas ficções extravagantes, a autobiografia concentra-se numa abordagem não espetacularizada da vida interior e da experiência cotidiana.

Os temas preferenciais dos quadrinhos também influenciam sua concentração em alguns gêneros específicos, já que a maior parcela das publicações é composta por histórias infantis, de aventuras, fantasia, ficção científica e culto ao herói. Dentro 
dessas categorias florescem uma infinidade de gêneros e subgêneros, fortemente marcados pelo tom aventuresco, como super-heróis, gangster, fantasia medieval, policial, space opera, funny animals, etc. Conforme a análise efetuada por Gerard Jones (2004), essa concentração desproporcional em torno de alguns gêneros estaria associada à consolidação dos quadrinhos como um produto industrial dos meios de comunicação midiática. Ou seja, o florescimento e popularidade desses gêneros específicos seriam determinados puramente por questões mercadológicas. Nesse contexto, a autobiografia se insere na contramão das demandas da indústria, já que oferece um tipo de experiência narrativa que não corresponde ao universo de expectativas, lugares-comuns e estruturas formais construídas pelos quadrinhos mainstream, que constituem a maior e mais lucrativa parcela do mercado, sempre seguindo as demandas do público e veiculando em profusão os gêneros de maior popularidade no momento. Além disso, a autobiografia apresenta uma estrutura mais fluída e com convenções menos reconhecíveis que os gêneros tradicionais, o que supostamente a transformaria numa manifestação menos palatável e, consequentemente, menos atrativa comercialmente.

Se no espaço limitado do mercado de quadrinhos a autobiografia se apresenta como um objeto fora de lugar, como manifestação cultural essa impressão é ainda mais acentuada. Juntamente com a suposta simplicidade de linguagem, um dos postulados mais comumente associados aos quadrinhos é sua limitação a categorias juvenis/infantis, atestado pela permanência de matérias jornalísticas pautadas em função do conceito "quadrinhos não são mais coisa de criança" (CAMPOS, 2006, p.14). Considerando a noção de que os quadrinhos são narrativas pueris, toscamente escritas e desenhadas que, no máximo, serviriam como um degrau para a fruição da literatura, causa estranheza a tentativa de construir uma modalidade narrativa que aborde a complexidade das relações humanas e as sutilezas da vida interior. A percepção social acerca das histórias em quadrinhos, principalmente ao modelo veiculado em revistas, em grande medida as qualifica como uma manifestação cultural inferior, destinada a veicular apenas o tipo mais simplório de entretenimento (WITEK, 1989, p.5), de modo que a sondagem da experiência de si e a representação da realidade social e histórica ficariam relegadas a modalidades artísticas mais "elevadas", como a literatura.

A despeito dos prognósticos desanimadores, no início da década de 1970 as primeiras narrativas autobiográficas em quadrinhos são publicadas nos Estados 
Unidos (ROSENKRANZ, 2002; GRAVETT, 2005; SKINN, 2004). É certo que sempre existiram autores de quadrinhos que, em maior ou menor grau, utilizaram suas experiências de vida como mote para narrativas, mas a autobiografia, conforme formulada na tradição estadunidense, constitui-se como um objeto particular, já que pode ser reconhecido como uma modalidade de narrativa do "eu". Essas primeiras narrativas produzidas por autores como Robert Crumb, Justin Green e Art Spiegelman (GRAVETT, 2005, p. 56), já apresentam características formais e discursivas que permite inseri-las na tradição de narrativas autobiográficas e confessionais.

Desde a década de 1970 a autobiografia vem desempenhando um papel importante no mercado de quadrinhos, ampliando suas possibilidades formais e contribuindo para uma maior aceitação social da mídia como objeto de expressão séria. Embora não disponham da mesma popularidade e potencial mercadológico que outros gêneros tradicionais da indústria, os quadrinhos autobiográficos possuem um público cativo, muitas vezes composto por leitores que habitualmente não se interessam por quadrinhos (HATFIELD, 2005). Além disso, o gênero tem apresentado grande vitalidade, sendo praticado por um número crescente de criadores que continuamente expandem suas possibilidades expressivas.

Dentro dessa matriz autobiográfica dos quadrinhos dos EUA, Robert Crumb é um dos criadores mais destacados. Seu papel proeminente é reforçado por diversos aspectos, já que Crumb é um dos precursores dessa modalidade narrativa, um dos mais prolíficos criadores e exerce uma grande influência sobre outros artistas. Seu lugar central também é reforçado pelo reconhecimento que seu trabalho adquiriu fora do âmbito específico dos quadrinhos, de modo que a figura do autor e a iconografia de seu estilo pictográfico é facilmente reconhecível no âmbito cultural.

A obra desenvolvida por Crumb durante os anos 1970 se relaciona diretamente com a formação dos quadrinhos autobiográficos e a sua influência sobre o desenvolvimento dos quadrinhos alternativos no mundo é um processo que dificilmente pode ser superestimado. No Brasil, as primeiras histórias em quadrinhos de Crumb foram publicadas na revista Grilo 26, de maio de 1972. Segundo Gonçalo Silva Jr (2012, p.161), a partir dessa edição Robert Crumb tornou-se a atração principal da revista, mesmo com os "retoques" e "correções" a que a arte precisava ser submetida para aprovação pela censura prévia. Após o encerramento das atividades da revista, Crumb foi publicado de forma esporádica no Brasil, em revistas 
como O Bicho (1975), As Aventuras de R. Crumb (1986) e Porrada! (1988). Apenas recentemente sua obra foi mais amplamente divulgada pelos diversos livros publicados pela editora Conrad, como Fritz the cat (2002), Blues (2004) e Minha Vida (2005). Entre os cartunistas brasileiros que iniciaram suas atividades após a década de 1970 é marcante a influência de Crumb no que se refere à temática, pictografia e estilo narrativo. No trabalho de cartunistas como Angeli, Laerte, Glauco, Francisco Marcatti, Adão Iturrusgarai e Allan Sieber os elementos derivados da obra de Crumb são claramente reconhecíveis.

A grande influência de Crumb e outros artistas ligados ao Comix (o quadrinho underground desenvolvido nos Estados Unidos durante o final da década de 1960) sobre os artistas brasileiros é um evento bastante peculiar, considerando a robusta tradição de quadrinhos e cartuns humorísticos do Brasil (SANTOS, 2004, p.4). Embora muito da tradição satírica brasileira ainda possa ser encontrada nos quadrinhos surgidos após a redemocratização, em muitos sentidos a geração de quadrinistas alternativos da década de 1980 parece estar mais ligada aos quadrinhos produzidos nos Estados Unidos. Para uma geração que experimentou a liberdade política após quase trinta anos de repressão, o espírito anárquico e subversivos dos quadrinistas underground parecia responder melhor a suas necessidades criativas.

Angeli, em particular, sempre enfatizou a influência de Crumb sobre seu trabalho (ANGELI, 1985, p.41). Em seus primeiros quadrinhos já é possível visualizar várias aproximações temáticas e de estilo, além da semelhança da configuração pictográfica. Assim como Crumb, Angeli também inicia a produção de histórias em quadrinhos de teor autobiográfico, sendo um dos primeiros autores brasileiros a praticar esse gênero. Na série de tiras e histórias curtas intitulada Angeli em Crise, o autor protagoniza histórias extravagantes e bem humoradas que tematizam uma experiência de urbanidade e os dilemas existências enfrentados pelo homem que se adapta aos novos tempos de liberação feminista.

Os quadrinhos autobiográficos de Angeli foram publicados no jornal Folha de S. Paulo e na revista Chiclete com Banana, apresentando o gênero para um grande público leitor. Embora a autobiografia nunca tenha alcançado no país a mesma popularidade dos Estados Unidos, ao longo dos anos um grande número de autores brasileiros, como Laerte (Laertevisão e nas tiras da série Piratas do Tietê, publicadas na Folha de S. Paulo), Glauco Mattoso (As aventuras de Glaucomix, o pedólatra), Lourenço Mutarelli (Caixa de Areia), Allan Sieber (na série de tiras 
Preto no Branco e Allan Sieber talk to himself show), Chiquinha (histórias curtas publicadas em seu blog), Cynthia B. (revista Piauí, Bananas) e Caeto (Memória de Elefante), passaram a utilizar de forma recorrente a modalidade autobiográfica em suas produções. $\mathrm{Na}$ dispersão desses elementos é possível encontrar indícios do trabalho seminal de Robert Crumb, transmitidos de forma direta ou pelo filtro da obra de Angeli. As relações entre a matriz autobiográfica dos quadrinhos norte-americanos e o modelo de autobiografia desenvolvido no Brasil é um dos principais pontos de interesse do presente estudo.

Dado o papel preponderante dos autores Robert Crumb e Angeli, um mapeamento de suas narrativas autobiográficas possibilita perceber transformações importantes no modelo discursivo utilizado bem como as mudanças do mercado de quadrinhos alternativos. No caso de Crumb abordaremos o período compreendido entre 1969, quando são identificáveis os primeiros experimentos de autorepresentação, e 1992, data da publicação da última revista Weirdo (publicação criada por Crumb que durou 24 números). Utilizaremos, principalmente, como fonte os 17 volumes da série The Complete Crumb publicada pela Fantagraphics Books, desconsiderando a série Dirty Laundry Comics, feita em parceria com a quadrinista Aline Kominsky-Crumb. No caso de Angeli utilizaremos como fonte os 24 números da série regular da revista Chiclete com Banana. Para a análise formal dessas histórias curtas utilizaremos as proposições de diversos teóricos dos quadrinhos, aliando também a esse modelo a interface possível com as teorias da arte (gestalt; psicologia do receptor) e da narratologia (narrativas do eu; teoria crítica).

Para além do aspecto formal da linguagem dos quadrinhos, tentaremos descrever os fenômenos culturais decorrentes das interelações entre as matrizes autobiográficas, processos de aceitação social e a esfera da "instituição arte" (BÜRGER, 2012). Esse modelo de investigação, que relaciona manifestações artísticas e o papel do criador com a esfera social, assemelha-se a estudos realizados no âmbito da teoria literária (WATT, 2010) e da história da arte (GOMBRICH, 2007). Além disso, utilizaremos também algumas proposições advindas da arqueologia desenvolvida por Michel Foucault (2006) como pressupostos teóricos e metodológicos.

A arqueologia foucaultiana insere-se no estudos da análise do discurso, teoria surgida no interior da linguística que vem contribuindo para o campo da comunicação alargando a noção de linguagem para além do simples instrumento de transmissão de 
informação, introduzindo-a também como um modo de produção social. Considerando que os quadrinhos autobiográficos articulam-se como uma expressão artística que se relaciona com processos sociais complexos, a tentativa de analisar as condições de produção desse discurso pode ajudar a compreender as transformações ocorridas nos quadrinhos estadunidenses e, posteriormente, nos quadrinhos brasileiros. Assim, somos levados a problematizar quais são as relações entre processos discursivos e não-discursivos, entre poderes constituídos e campos em ascensão, entre a repetição de estruturas cristalizadas e as inovações da ação autoral que incidem sobre a constituição desse objeto teórico de pesquisa.

O noção de "condição histórica de possibilidade", presente na descrição arqueológica foucaultiana, norteará uma análise centrada nos aspectos discursivos do quadrinhos autobiográficos. A arqueologia é fundamentalmente uma metodologia de análise dos discursos que não é formalista nem interpretativa (FOUCAULT, 2007). Segundo Castro (2009, p.42), “enquanto a unidade de trabalho das metodologias formalistas é a proposição-significante e a unidade de interpretação é a frasesignificado, a arqueologia se ocupa de enunciados e formações discursivas". Assim, pode-se dizer que arqueologia não possui uma analogia com a exploração geológica cuja escavação desvendaria as camadas de sentido. Sobre a arqueologia, Foucault esclarece:

Esse termo não incita à busca de nenhum começo; não associa a análise a nenhuma exploração ou sondagem geológica. Ele designa o tema geral de uma descrição que interroga o já dito no nível de sua existência; da função enunciativa que nele se exerce, da formação discursiva a que pertence, do sistema geral de arquivo de que faz parte. A arqueologia descreve os discursos como práticas especificadas no elemento do arquivo (FOUCAULT, 2007, p.149).

Sabendo que para Foucault o arquivo "não faz referência, como na linguagem corrente, nem ao conjunto de documentos que uma cultura guarda como memória e testemunho de seu passado, nem à instituição encarregada de conservá-los", e sim ao "sistema de condições históricas de possibilidade dos enunciados" (CASTRO, 2009, p.43), a investigação arqueológica deve primeiramente determinar as condições históricas de possibilidade desse discurso. 
O estudo da condição histórica de possibilidade diz respeito às condições de produção e o a priori histórico do discurso da autobiografia em quadrinhos. Podemos entender sua influência tanto em termos de evolução da linguagem dos quadrinhos, que definem a forma do que é dito, como em termos de seu relacionamento entre campos distintos (principalmente a polarização campo dos quadrinhos - arte), que definem o que pode ser dito. Assim, na definição da condição histórica de possibilidade tentaremos abordar os aspectos técnicos e formais ao mesmo tempo em que problematizamos as relações entre o campo de emergência da autobiografia e processos sociais que determinam uma maior aceitação dos quadrinhos como objeto de expressão séria e socialmente relevante.

Assim, o projeto de investigação da autobiografia em quadrinhos que ora desenvolvemos possui uma perspectiva dupla, já que visa dar conta do surgimento dessa modalidade de expressão em dois contextos específicos: o norte-americano e o brasileiro. Na primeira etapa desse estudo abordaremos o a priori histórico e as condições de produção desse discurso no mercado de quadrinhos dos Estados Unidos, conforme as fases metodológicas da arqueologia de inspiração foucaultina. Dando continuidade, empreenderemos a mesma investigação visando o desenvolvimento da autobiografia em quadrinhos no Brasil, sempre tentando articular os feixes de relações entre os dois países. Contudo, essa perspectiva não deve ser tomada como um estudo comparativo per si, já que não definimos categorias semelhantes para comparação, nem utilizamos uma metodologia específica para esse fim. Em cada caso acontece um estudo arqueológico particular, já que o desenvolvimento dos quadrinhos nos dois países acontece em momentos diferentes e contextos diversos. Portanto, essa perspectiva comparativa limita-se a apontar semelhanças e diferenças entre o desenvolvimento do mercado de histórias em quadrinhos e da sua modalidade autobiográfica nos dois países, bem como a influência de modelos mercadológicos, formatos da indústria e gêneros narrativos. 


\section{CAPÍTULO I - AUTOBIOGRAFIA EM QUADRINHOS NOS ESTADOS UNIDOS}

\subsection{Do comic book ao Comic Code}

A autobiografia em quadrinhos constitui-se como uma ruptura dentro do mercado dos EUA, descontinuidade marcada principalmente pela oposição entre as temáticas tradicionalmente utilizadas no mercado de quadrinhos e a natureza realista da autobiografia. Conforme Joseph Witek

Comic books in America have not often used to tell stories about real lives and actual events. The comics tradition for us lies elsewhere: in the realms of fantasy, of wish fulfillment, of projections of power, and in the ritual repetition of generic formulas (WITEK, 1989, p.13).

Desde a consolidação da indústria de quadrinhos, ocorrida no final da década de 1930 (JONES, 2006, p.175), existe uma forte polarização em torno de gêneros associados ao humor e à aventura, como super-heróis, histórias policiais, ficção científica etc. Mesmo entre as narrativas que utilizavam elementos da realidade, como os crimes verdadeiros e histórias de gangsters da revista Crime Does Not Pay, a experiência desenvolvida se afastava da referencialidade em função da pura ficção. Considerando a natureza da linguagem dos quadrinhos, não existe nada que associe essa mídia a pressupostos antirrealistas ou fantasiosos. Mesmo assim, os rumos seguidos pelo mercado aproximaram as histórias em quadrinhos ao universo do que se encontra fora da experiência comum.

Embora durante as primeiras décadas do século $\mathrm{XX}$ já existissem séries diárias, personagens icônicos e um público formado por milhões de leitores, o mercado de quadrinhos era limitado aos jornais e republicações esporádicas de tiras. Nesse contexto, os quadrinhos eram percebidos como um atrativo a mais na disputa pelos leitores de jornais, como atesta a influência exercida pela guerra entre os magnatas da comunicação Joseph Pulitzer (New York World) e Willian Randolph Heast (New York Journal) sobre o desenvolvimento das primeiras séries de 
quadrinhos (The Yellow Kid e Katzenjammer Kids, respectivamente). Segundo Nilson Lage (2001, p.14), a concorrência é o principal fator para o desenvolvimento de diversos gêneros que o jornal passou a abrigar, como a histórias de interesse humano (fait divers), horóscopo, sessão de cartas, e quadrinhos (tiras e páginas dominicais). Dentro dessa nova configuração do jornalismo, os quadrinhos adquiriram importância, já que poderiam influenciar diretamente a escolha do periódico.

$\mathrm{O}$ aumento da popularidade dos quadrinhos nos jornais foi acompanhado por uma crescente profissionalização do meio, culminando no sistema dos syndicates, empresas que vendiam e distribuíam as tiras para jornais de todo o país. Os syndicates desenvolveram um modelo de comercialização que barateava os custos, permitindo que até os mais modestos jornais pudessem bancar a publicação das séries mais populares. Se, por um lado, esse sistema ampliava o número total de leitores e permitia que o cartunista se dedicasse inteiramente a produção da tira, por outro, a distribuição ostensiva diminua consideravelmente a demanda por artistas e novas criações. Somente após a popularização do formato conhecido como comic book, revista em quadrinhos de 24 páginas semelhante ao gibi brasileiro, os quadrinhos ganham força como produto de entretenimento autônomo e o mercado assume sua configuração moderna. Segundo Santiago García

O comic book será um passo decisivo na evolução dos quadrinhos, pois permitirá que se desliguem da imprensa geral ou humorística e alcancem uma autonomia como meio, além de ser um suporte onde terão espaço, finalmente, as histórias de longa extensão, ou pelo menos de extensão superior a uma página (GARCÍA, 2012, p.112).

Ainda que já existissem republicações de tiras diárias nas bancas de jornais, o comic book está mais associado ao mercado de revistas baratas que aos syndicates. A grande diferença do novo formato em relação às compilações de tiras antigas é que o comic book apresentava histórias inéditas e abordava temas mais diversificados. Sem o controle editorial rígido do syndicates, esse formato também favorecia uma maior experimentação no que se refere aos gêneros e temáticas abordadas. Além disso, a efervescência do mercado editorial estimulava a busca constante por novos modelos narrativos. Segundo Jones, 
Na década de 1920, os americanos começaram a comprar revistas como nunca. Tecnologia de impressão barata, distribuição na era dos automóveis, dinheiro para gastar e uma fome de informações sobre um mundo que mudava a cada dia conspiraram para tornar a banca de revistas uma das principais arenas da cultura nacional. No início da década havia nas bancas mais de 2 mil títulos. Os americanos passavam mais tempo lendo revistas do que em qualquer outra atividade de lazer (JONES, 2006, p.75).

Nesse mercado em ascensão, qualquer editor que descobrisse um novo nicho poderia obter lucro com um investimento moderado; editoras eram criadas e desapareciam com a mesma rapidez e era prática comum que um mesmo editor utilizasse várias empresas de fachada em manobras escusas de contabilidade. O caráter fluído dessas organizações editoriais permitia que as revistas seguissem de perto qualquer tendência ou interesse do público, lançando publicações inusitadas e uma profusão de cópias dos maiores sucessos de venda (JONES, 2006).

Esse mesmo caráter de maleabilidade editorial pode ser identificado na formação do mercado de quadrinhos. Um exemplo disso é que os primeiros comic books, publicados em 1933, eram cópias de Dick Tracy recusadas pelos syndicates (JONES, 2006, p.110). Nos anos seguintes, tornou-se comum que material rejeitado pelas agências seguisse o rumo das bancas, de forma que os comic books acompanhavam as mesmas tendências das tiras mais populares. Entre as imitações de Tarzan, Terry and the Pirates e Mandrake, o surgimento do Superman inaugura um gênero que não possuía equivalente nas tiras de jornais: o super-herói. Criado por Jerry Siegel e Joe Shuster em 1933 e lançado apenas em 1938 na revista Action Comics, o Superman mostrou-se um grande sucesso comercial, imediatamente seguido por várias personagens similares. A realização física vigorosamente representada nas narrativas de superpoderes respondia perfeitamente aos anseios de uma sociedade ainda impregnada pelo sentimento de impotência advindo da grande depressão, de modo que a "popularidade dos super-heróis deve-se principalmente ao fato de terem trazido resposta às profundas contradições que se desenvolveram na sociedade norte-americana" (DORFMAN, 1978, p.71). Ao mesmo tempo, sua permanência na cultura pop demonstra sua eficácia como modelo de representação de fantasias de poder. É certo que a aceitação comercial dos super-heróis deu provas da eficácia do comic book como formato editorial. 
Nos anos seguintes, o sucesso editorial do comic book impulsionou a expansão do mercado. É iniciada a chamada Era de Ouro dos Quadrinhos, período de grande vitalidade criativa e comercial, dominado pelos super-heróis, com pequena participação de outros gêneros, como faroeste e histórias infantis. Existem algumas divergências acerca da duração da Era de Ouro, mas é comum apontar o período que compreende o final dos anos 1930 até o final da década de 1940. Jones (2006, p.175) situa o início da "febre do comic book" entre o ano letivo de 1938 e 1939. Quanto a retração do mercado, Jones esclarece:

\begin{abstract}
A partir do início de 1945, com o fim da guerra à vista, as vendas de gibis de super-heróis começaram a cair. Até o final de 1946, tinham caído em mais de 30\%. Em 1947, as editoras começaram a sair em busca de novos campeões de vendas: jorraram histórias em quadrinhos com temas cômicos, de faroeste, românticos, de crime ou de horror. Até o final de 1948, a maior parte dos super-heróis tinha desaparecido; as revistas apelaram para outros gêneros. Sobraram só os mais famosos, e estes se voltaram de forma mais consciente para o público juvenil (JONES, 2006, p.292).
\end{abstract}

O declínio dos comics de super-heróis marcou a ascensão de outros gêneros menos vinculados ao público infantil, implementando novos modelos narrativos e expandindo o espectro de temas abordados. "Impulsionada pelos novos gêneros, um número ainda maior de americanos passou a ler gibis. Ao final da década, havia cerca de 40 editoras vendendo 300 títulos - 50 milhões de revistas ao mês" (JONES, 2006, p.296).

A liberdade do modelo do comic book permitia que os editores desenvolvessem projetos mais ousados em termos de violência gráfica e tratamento mais realistas de processos sociais e históricos. Em oposição ao coloridos superheróis que poucos anos antes dominavam as bancas, as revistas em quadrinhos de crime e horror causavam uma impressão bastante negativa. Nesse contexto, inicia-se o processo de perseguição aos quadrinhos que culmina com o Comic Code Authority, sistema de autocensura da indústria. É certo que o mercado sempre comportou gêneros de violência explícita. Crime Does Not Pay, por exemplo, era publicada desde 1942 pela Lev Gleason Publications, mas em 1948 havia mais de 40 outros gibis de gangsters e crime reais (JONES, 2006, p.296). Da mesma forma, sempre 
houveram teorias alarmistas acerca dos supostos malefícios dos gibis sobre o desenvolvimento intelectual das crianças. Entre vários artigos difamatórios, o mais significativo (JACOBS, 2014, p.72; JONES, 2006, 201-202) foi o editorial intitulado A National Disgrace (And a Challenge to American Parents), de Sterling North. Publicado em 8 de maio de 1940, no jornal Chicago Daily News, o editorial foi reproduzido em diversos jornais por todo o país, causando bastante comoção entre país, educadores e religiosos. Nesse texto é possível constatar a diferente percepção que existia entre os funnies (tiras de jornal) e o novo formato do comic book:

We imagined as do most parents that they were no worse than the "funnies" in the newspaper. But a careful examination of the 108 periodicals now on the stands shocked us into activity. At last 70 percent of the total were of a nature no respectable newspaper would think of accepting (NORTH, 1940).

Esse breve enxerto ajuda a demonstrar que, enquanto as tiras de jornais eram um formato consolidado e aceito socialmente, o comic book era visto com desconfiança. Obviamente, as necessidades comerciais dos syndicates impunham diretrizes editoriais muito rígidas, resultando em um produto final bastante anódino e inofensivo. Além disso, era prática comum que o rascunho das tiras fosse enviado para aprovação com uma semana de antecedência, de maneira que dificilmente um material de gosto duvidoso ou que pudesse causar polêmica seria publicado com o aval dos syndicates. O comic book, por outro lado, dispunha de um controle editorial mais brando, quase inexistente.

O restante do editorial de Sterling North traça relações entre a leitura dos gibis e prejuízos cognitivos, bem resumidas no parágrafo final:

The old dime novels in which an occasional redskin bit the dust were classic literate compared to the sadistic drivel pouring from the presses today. Badly drawn, badly written and badly printed - a strain on young eyes and young nervous systems - the effect of these pulp-paper nightmares is that of a violent stimulant. Their crude blacks and reds spoil the child's natural sense of color; their hypodermic injection of sex and murder makes the child impatient with better, through quieter stories. Unless we want a coming generation even more ferocious than the present one, parents and 
teachers throughout America must band together to break the "comic" magazines (NORTH, 1940).

Embora tenha um tom claramente alarmista, o artigo vincula os supostos malefícios das revistas em quadrinhos a uma perspectiva educativa, percebendo-os como um mecanismo de destruição da capacidade de fruição estética/literária da criança. Ou seja, vincula o "problema" do comic book a uma questão de gosto. No final da década de 1940 acontece um deslocamento no teor da crítica aos quadrinhos dos Estados Unidos, aproximando-se cada vez mais do terreno da psicologia social. Esse processo se intensifica na década seguinte.

Em março de 1948, a longa reportagem Horror in the Nursery, de autoria de Judith Crist, apresenta ao grande público o psiquiatra Fredric Wertham, figura central no processo de difamação aos quadrinhos. Publicada na Collier's Magazine, a reportagem apresentava as teorias de Wertham, que traçavam relações entre o funcionamento do cérebro, a leitura de gibis e a delinquência juvenil. Wertham era um psiquiatra de origem alemã, especializado no funcionamento da mente criminosa que, ainda durante os anos 1930, ganhou certa notoriedade por traçar o perfil psicológico do serial killer Albert Fish (SCHECHTER, 2013). Wertham desenvolvia um projeto de assistência psicológica para jovens em situação de risco e, ao perceber que quase a totalidade desses jovens infratores eram leitores de comic books, tentou estabelecer relações entre a leitura de histórias de crime/horror e o comportamento de seus pacientes. Além do caráter psiquiátrico, sua crítica aos quadrinhos era também inspirada pelas teorias de Theodor Adorno acerca da indústria cultural (SANTOS, 2011, p.62; JONES, 2006, p.333). Assim, durante todo o ano de 1948 Wertham promoveu sua causa em artigos como The Comics... Very Funny!, publicado no Saturday Review of Literature e condensado na edição de agosto da Reader's Digest. Além disso, coordenou o simpósio The Psychopathology of Comic Books, onde diversos psiquiatras descreveram os efeitos danosos dos quadrinhos, propondo a regulamentação da indústria e banimento dos gêneros mais violentos.

Além do alarmismo de Wertham e da corrente psiquiátrica, outros eventos contribuíram para a implantação efetiva do Comic Code Authority em 1954. O primeiro diz respeito à própria indústria, com o surgimento dos quadrinhos de terror mais sofisticados e graficamente explícitos publicados pela editora EC Comics. A 
história da editora e os rumos que levaram à publicação desse material mais adulto são bastante peculiares. Maxwell Charles Gaines, o fundador da editora, foi um dos pioneiros da indústria dos quadrinhos dos Estados Unidos que, durante muitos anos, teve uma sociedade com Jack Liebowitz na editora All-American Comics. Após o termino da sociedade, criou a editora Educational Comics com o claro intuito de produzir quadrinhos mais socialmente aceitos. Os principais títulos lançados foram a série religiosa Pictures Stories From the Bible, uma imitação da Mulher-Maravilha chamada Moon Girl \& the Prince, Blackstone, o mágico, e as revistas de humor infantil Tiny Tots, Fats \& Slats e Animal Fables. Com pouco apelo junto ao público, a editora enfrentava sérios problemas financeiros e, após a morte de Charles Gaines em 1947, seu filho, Willian (Bill) Gaines, assumiu uma companhia quase falida (JONES, 2006).

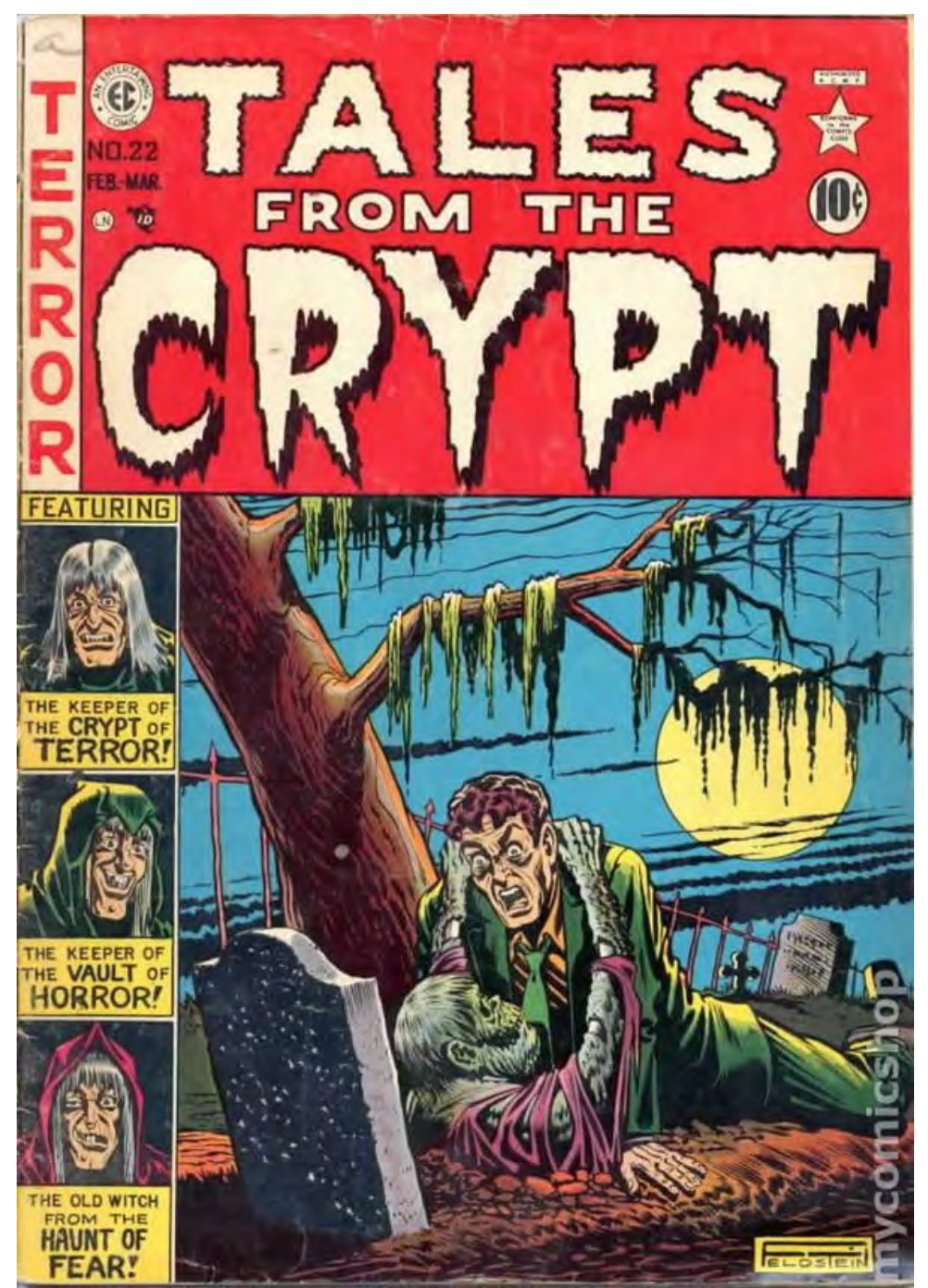

Figura 1 - Tales from the Crypt $n^{\circ} 22$ 
Juntamente com o artista Al Feldstein, Bill Gaines tentou adequar a editora aos populares temas de crime, mistério, horror e fantasia, dando início a uma reestruturação: a editora passa a se chamar Entertaining Comics; as revistas religiosas e infantis são eliminadas do catálogo; Moon Girl se transformou em Moon Girls Fights Crime; e Blackstone assumiu o pomposo título Blackstone the Magician Detective Fights Crime. Também foram lançados os títulos Modern Love, Saddle Justice e War against Crime. No começo de 1950 é lançada a EC New Trend, com os icônicos títulos Weird Science, Tales from the Crypt, Vault of Horror, Haunt of Fear e Weird Fantasy.

As séries de terror e fantasia da EC mostraram-se um grande sucesso de público e atualmente ainda são reconhecidas pela narrativa sofisticada e inventiva (GRAVETT, 2005, p.104). Além da qualidade inerente, esses quadrinhos se diferenciavam dos outros títulos de terror por incorporarem em sua narrativa um caráter de autoreferencialidade que muitas vezes chamava atenção para própria estrutura da linguagem dos quadrinhos. A forma como incorporavam, à sua lógica interna de funcionamento, temáticas realistas também era mais elaborada do que a de seus antecessores e concorrentes. Conforme Jones

Bill Gaines e Al Feldstein imitavam o suspense dos programas de rádio dos quais gostavam; faziam histórias de terror com tramas tensas, excesso de narrativa, descrições macabras e finais em que não faltavam lances cruelmente cômicos. À vontade para expor as vilezas da vida moderna com a liberdade que o rádio não permitia, dedicaram-se, com um riso maldoso, a virar do avesso a sentimentalidade americana. Mostraram pais de família respeitáveis torturando os filhos, meninos de tenra idade tramando a morte dos pais, jovens casais destilando veneno homicida, e acima de tudo, mulheres sensuais acabando com a raça de jovens idiotas fascinados com seus encantos (JONES, 2006, p.316).

Mesmo com o óbvio flerte com o sobrenatural, os quadrinhos da EC muitas vezes rompiam com as convenções do horror (castelos sombrios, monstros, etc) em função de tramas ancoradas na realidade contemporânea. A incorporação de temas como prostituição, vício e conflitos raciais revela um elevado grau de realismo na maneira como são construídas suas representações sociais. 
Enquanto isso, Fredric Wertham continuava sua cruzada contra os quadrinhos e viu nos gibis da EC um nível mais elevado de degeneração. Em 1952, uma manobra política colocou em evidência a questão dos gibis. Estes Kefauver ganhou em 12 primárias a indicação para candidato à presidência, colocando-o como um concorrente forte para a eleição seguinte. Para tentar manter o interesse do público, elegeu a delinquência juvenil como plataforma política. Segundo Jones (2006, p.331), a delinquência juvenil era "um tema que preocupava o país tanto quanto o crime organizado". Com o apoio de Kefauer, Wertham foi eleito conselheiro psiquiátrico da Subcomissão Judiciária da Comissão Parlamentar sobre Delinquência Juvenil em 1953, mesmo ano em que começou a escrever o livro Seduction of the Innocent, onde expunha suas teorias sobre os efeitos danosos dos quadrinhos. Coincidentemente, o livro foi ilustrado com muitas imagens de violência gráfica extraídas dos quadrinhos da $E C$. Acerca do livro, Jones esclarece

\begin{abstract}
De estilo fluente e conteúdo alarmista, muitas vezes melífluo, consta que o livro na verdade foi escrito por Gershon Legman, que chamara Harry Donenfeld de pornógrafo em seu próprio livro, Love and Death. Os capítulos tinham títulos como "Eu Quero Ser um Maníaco Sexual", "Os Aliados do Demônio", e "Homicídio em Casa". Seduction of the Innocent é cheio de exageros e causalidades forçadas - o livro cita o caso de uma menina de 10 anos de idade que rodava pelo cais à noite vendendo sexo, e diz que os culpados eram os quadrinhos de crime -, mas o que faltava em termas de ciência e raciocínio era mais que compensado pela simples feiúra dos exemplos escolhidos. Quando o livro saiu, em 1954, pouco tempo antes da subcomissão de Kefauver começar sua investigação dos quadrinhos, seu conteúdo chocou o pais e aterrorizou as editoras (JONES, 2006, p. 331-332).
\end{abstract}

Além do exagero acerca dos efeitos dos gibis, uma das críticas mais comuns às teorias de Wertham é que mais de 90\% das crianças dos anos de 1940 eram leitoras de gibis, de modo que era esperado que a grande maioria dos jovens delinquentes fossem leitores de quadrinhos. Fazendo o raciocínio inverso, o número de infratores era insignificante se considerado o conjunto total de leitores de quadrinhos.

A Subcomissão Judiciária da Comissão Parlamentar sobre Delinquência Juvenil se preocupou bem mais com questões sociais, como políticas públicas de internamento e o problema das drogas. Quanto aos meios de comunicação, 
concentrou-se bem mais na TV que nos quadrinhos. Ironicamente, Bill Gaines, o editor/escritor da EC Comics, desempenhou um papel desastroso no andamento da investigação. Enquanto todos os outros editores de quadrinhos preferiram deixar a Comissão seguir sua investigação, Gaines estava convencido de que poderia articular uma defesa, cooptando especialistas e intelectuais que pudessem prestar um depoimento favorável aos quadrinhos. Sem encontrar respaldo junto aos outros editores, Gaines acabou depondo sozinho e acabou dando respostas bem pouco consistentes quando questionado acerca de algumas imagens de violência explícita veiculadas nos quadrinhos da EC. Alguns meses depois, o Comic Code Authority foi implantado. Segundo Paul Gravett

The month of October 1954 marked a turning point in American comic books. It saw the majority of publishers start to pay to submit their pages for spring 1955 in advance to the newly formed Comic Code Authority or CCA, an independent regulatory commission financed by the industry and empowered to remove anything remotely objectionable. Without the CCA's big white postage stamp of approval printed up to one inch across at the top right corner of its cover, a comic book would not be handled by distributors and retailers and thus would not reach the public (GRAVETT, 2005, p.102).

O código interno criava restrições bastante amplas, como a proibição do uso dos termos "horror" e "terror" nos títulos das revistas, bem como a eliminação de cenas de violência excessiva, nudismo e roupas provocantes. Ainda aconselhava que o crime nunca fosse mostrado de forma a criar simpatia pelo criminoso e que o bem sempre prevalecesse sobre o mal em qualquer situação. Antes de ir para as bancas, os quadrinhos eram analisados e, caso seguissem todas as indicações do código, ganhavam um selo de aprovação.

A reação exagerada da indústria de quadrinhos, ao mesmo tempo em que respondia a determinadas demandas de setores mais conservadores da sociedade, também funcionava como uma estratégia mercadológica desenvolvida por alguns editores para eliminar a concorrência e afastar atenção indesejada. 
Wertham has been demonized as a censor by fans and collectors, but he never proposed or endorsed the CCA, let alone book burnings. His solution, "that the most gory comic books should not be directly displayed to children 13 and under," sparked little interest, because the public outrage that he helped to inflame was baying for much tougher curbs. The industry's exaggeratedly severe Comics Code was partly an overreaction to pressure, and partly a public relations exercise, but it was effectively also a sly business maneuver by the major conservative companies, led by Archie publisher John Goldwater, to drive annoying competitors into line or preferably out of business, stifling divergent points of view and making more rack space for their own product (GRAVETT, 2005, p.102).

O Comics Code realmente possuía algumas indicações que claramente visavam a eliminação dos títulos de terror, horror, gangster e crimes reais. O item número seis eliminava qualquer tipo de violência física: "Scenes of excessive violence shall be prohibited. Scenes of brutal torture, excessive and unnecessary knife and gunplay, physical agony, gory and gruesome crime shall be eliminated"; e o onze impossibilitava qualquer quadrinho de terror: "Scenes dealing with, or instruments associated with walking dead, torture, vampires and vampirism, ghouls, cannibalism, and werewolfism are prohibited". García também corrobora a tese de eliminação da concorrência:

\begin{abstract}
A proibição das palavras "horror" e "terror" parecia atentar diretamente contra as coleções da EC Comics - afinal, muitos consideravam Bill Gaines o principal culpado de todo o alvoroço -, e há uma corrente de opinião que acredita ser o Comics Code somente a desculpa que os principais editores utilizaram - com a DC na liderança - para purgar um mercado sobrecarregado e, especialmente, para eliminar Bill Gaines, um indivíduo que subiu muito alto, muito depressa (GARCÍA, 2012, p.156).
\end{abstract}

Em 1956, o número total de vendas de quadrinhos havia encolhido à metade do que fora cinco anos antes. As restrições impostas pelo Código de Ética praticamente eliminaram as revistas de terror, ficção científica e crimes reais, limitando o mercado a quadrinhos infantis, como Archie e Casper, e revistas românticas para moças. Entre os quadrinhos da EC, a MAD foi o único título que 
conseguiu permanecer nas bancas, já que seu formato tabloide a deixava isenta da sujeição ao Comic Code Authority.

A perseguição e extermínio dos quadrinhos da EC é exemplar como processo de exclusão material e discursiva de objetos fora do lugar. A grande inadequação do projeto editorial da EC New Trend foi justamente a tentativa de construir revistas em quadrinhos para adultos em um contexto social que ainda não comportava esse conceito. As tensões polarizadas em torno do "problema" das revistas em quadrinhos demonstram o quanto essa mídia constitui-se como um objeto associado ao conceito de infância, de forma que a história do desenvolvimento das histórias em quadrinhos nos Estados Unidos sempre está permeada por limitações formais, discursivas, estéticas e temáticas. Conforme Joseph Witek,

The nearly universal adoption of the Comic Code is perhaps the single most influential event in the history of the American comic book medium; it efficiently squelched the few postwar comic books that were groping toward a sophisticated audience, and in effect it decreed that all comic books would become the ill-crafted pap toward which most American comics tended anyway (WITEK, 1989, p.48-49).

Nesse sentido, o implementação do Comic Code Authority é um evento essencial para compreensão dos processos envolvem a recepção das diferentes modalidades narrativas que surgiram nos quadrinhos a partir da década de 1960, particularmente o movimento artístico denominado como comix e as narrativas autobiográficas. 


\subsection{Quadrinhos e contracultura}

O movimento artístico do comix (também grafado como commix), é talvez o evento que se relacione de forma mais direta com a autobiografia, não apenas pela presença dos pioneiros Green, Crumb e Spiegelman em ambas as manifestações, mas principalmente pela ampliação das possibilidades de expressão da mídia quadrinhos. Conforme a classificação de Patrick Rosenkranz (2002), os comix floresceram nos EUA entre 1963 e 1975, integrados à contracultura jovem. As relações entre o desenvolvimento dessa modalidade de quadrinho underground e a contracultura são bastante extensas e, em certo sentido, o próprio comix configura-se como uma contracultura. Para Ken Goffman (2004, p.13), contracultura pode ser definida como a oposição a qualquer corrente ou tendência dominante na sociedade/cultura, de forma que seria possível traçar uma espécie de "tradição" dessas rupturas. Partindo dessa perspectiva Goffman identifica na história uma série de contraculturas, como o sufismo (vertente mística do islamismo), o zen e o próprio Iluminismo; no contexto específico dos Estados Unidos aponta os transcendentalistas do século XIX e movimento beat dos anos 50. Tanto o movimento beat como os transcendentalistas são bastante representativos enquanto encenação do embate entre o conservadorismo dominante e forças subversivas pontuais, polarização bastante exacerbada na sociedade estadunidense. Tanto é assim que "a contracultura nos Estados Unidos foi durante muito tempo submetida a uma dialética entre posturas puritanas de seus colonos rurais e o liberalismo cultural de seus fundadores revolucionários mais urbanos" (GOFFMAN, 2004, p.253).

Até a década de 1960, a contracultura nos Estados Unidos tinha pouca relevância social, sendo mais significativa pela difusão de novas ideias. Os transcendentalistas, por exemplo, alcançaram certa popularidade principalmente devido a obra de Henry David Thoreau e Walt Witman, mas apenas um número irrelevante de pessoas efetivamente adotou os ideais de vida simples e retorno a natureza. Da mesma forma, sempre existiu grande interesse acerca do estilo de vida boêmio dos beats, mas o movimento nunca contou com um número significativo de integrantes. A particularidade do processo, ocorrido durante os anos 1960 diz respeito ao potencial de mobilização de um grande contingente de entusiastas dispostos a se engajar ativamente em projetos políticos e sociais. Conforme Goffman, 
Nos anos de 1960 todos os nossos tropos contraculturais ocuparam as ruas em alto e bom som ao mesmo tempo. Parecia que alguma espécie de prisão psíquica tinha sido aberta e todos os jovens estavam tentando escapar de lá. Maior liberdade para os indivíduos em pensamento, expressão e comportamento entraram em atrito - e tentaram se fundir - com uma crescente sensação de responsabilidade coletiva pelo fim da guerra, da pobreza e da injustiça (GOFFMAN, 2004, p.272).

Agregando uma série de subculturas e grupos heterogêneos, os movimentos jovens da época são normalmente identificados como "a" contracultura. Além da música, não existiam muitas modalidades expressivas que se adequassem à nova sensibilidade dos jovens ligados à contracultura. A plasticidade formal e facilidade de produção sempre permitiram que os quadrinhos seguissem de perto qualquer tendência e no caso da contracultura não foi diferente, de forma que o comix foi a primeira forma de narrativa popular integrada aos anseios da contracultura, anos antes do cinema, por exemplo.

Segundo Dez Skinn, o desenvolvimento dos comix foi marcado por três grandes influências: as tijuana bibles, revistas pornográficas de 8 páginas vendidas ilegalmente entre as décadas de 1930 e 1950 (2004, p.12); os quadrinhos de terror e ficção científica da EC Comics (2004, p.13); e a revista MAD (2004, p.14-15). Entre essas três manifestações, a influência mais controversa e difícil de constatar diz respeito às tijuana bibles. Conforme Skinn

The Tijuana Bibles have acquired a legendary status as arguably the earliest form of US underground comix and certainly the most outrageous. Anonymously produced from the 1930s through to the 1950 s, they were cigarrete-packet sized eight-page booklets, running on comic strip picture a page, dedicated to poking fun at every icon imaginable. Breaking both sexual taboos and legal copyrights - with it taking almost 50 years of litigation to prove them protected by the First Amendment - they parodied almost 1000 subjects, from Adolf Hitler and Al Capone to the Marx Brothers and Mickey Mouse (SKINN, 2004, p.26).

O caráter subversivo desses quadrinhos aproxima-se do espírito dos comix e algumas paródias sexualmente explícitas, como as aventuras dos personagens Disney 
em Air Pirates Funnies (1971), revisitavam a narrativa das tijuana bibles. Contudo, alguns artistas, como Robert Willians, argumentam que os artistas ligados aos comix ainda eram crianças durante os conservadores anos 50, o que dificultaria muito o contato com esse material.

A influência dos quadrinhos de terror e ficção científica da EC Comics, por outro lado, é bastante reconhecida por figuras centrais no movimento comix, como Spain Rodriguez, Robert Willians, S Clay Wilson e Art Spiegelman (SKINN, 2004, p.13). Além disso, alguns autores como Richard Corben construíram sua obra como uma continuidade direta dos quadrinhos de terror da década de 1950. Entre os quadrinhos da EC, a revista MAD é a que teve mais influência sobre os quadrinhistas do underground. Lançada em 1952, a MAD é uma revista humorística originalmente editada/escrita por Harvey Kurtzman e desenhada por artistas da EC mais associados à temática de terror, como Wally Wood, Will Elder e Jack Davis. Para fugir às restrições do Comic Code, a partir da edição 24 a revista abandonou padrão do comic book colorido, assumindo o formato magazine em preto e branco. Durante muitos anos após a implementação do Comic Code, a MAD foi a única revista em quadrinhos que manteve uma postura subversiva e seu impacto ultrapassou os limites do mercado de quadrinhos.

A revista $\mathrm{Mad}$, que originalmente tinha o subtítulo "Humor na Jugular" e era apresentada como uma revista em quadrinhos para atrair pré-adolescentes, misturava humor juvenil simplório com sátiras sofisticadas e maliciosamente subversivas que debochavam de tudo no mundo adulto, variando de chefes políticos e militares aos pais de cada garoto (GOFFMAN, 2004, p.269).

O estilo de humor sofisticado e iconoclasta de Kurtzman repercutiu sobre toda uma geração de autores. Robert Crumb, em particular, sempre foi um grande admirador de seu estilo narrativo. Em uma carta escrita em 1959, Crumb faz uma apreciação muito significativa da revista MAD pós-Kurtzman:

Kurtzman's MAD was of exceedingly higher quality to the present publication of the name! MAD is now made to suit the average teenage tastes... It's funny but... well, something about 
Kurtzman's humor that's much funnier. It doesn't make you laugh out loud like Mad does, you get a deep inner enjoyment... like I found in Kurtzman's Jungle Book... 'Tis a gem... that'n is! (CRUMB, 2012, p.81).

Após deixar a revista MAD, Kurtzman ainda contribuiu para o desenvolvimento do comix publicando na revista HELP! (1960) os primeiros trabalhos profissionais de Robert Crumb, Skip Williamson, Jay Lynch e Gilbert Shelton.

Embora as sátiras e histórias humorísticas da revista MAD desvelassem críticas sociais bastante ácidas, a política editorial de uma publicação para jovens impedia a realização de narrativas mais extremas. No contexto de produção e distribuição alternativa do comix, inexistiam amarras editoriais, necessidade de sujeição ao Comic Code e bom-senso. Essa liberdade está relacionada com o barateamento das técnicas de impressão, particularmente o offset, que permitia que publicações em pequena escala se tornassem economicamente viáveis.

\begin{abstract}
The underground press made its appearance in 1965, when new technology in the offset printing process made it feasible to produce small runs of a tabloid newspaper for a few hundred dollars. Within a few months of each other, the Los Angeles Free Press, the Berkeley Barb, and the East Village Other debuted. The San Francisco Oracle, Detroit's Fifth Estate, the Chicago Seed, and many more soon followed (ROSENKRANZ, 2002, p.39).
\end{abstract}

Desde a década de 1920 existiam publicações alternativas com pequenas tiragens impressas em mimeógrafos e prensas artesanais. Essas primeiras revistas amadoras são comumente denominadas como fanzines, palavra surgida da união das palavras fan e magazine. Como a palavra indica, fanzines são produções gráficas feitas por fãs, normalmente sobre um tema ou personagem específico. Essas publicações surgiram em torno da comunidade de fãs da revista pulp Amazing Stories. A literatura pulp era composta por livros de bolso com capas bastante coloridas e miolo em papel jornal. As histórias, consideradas de baixa qualidade e sub-literárias (embora alguns bons escritores como Robert E. Howard e H. P. Lovecraft tenham despontado nessas revistas), tinham abordagens bastante 
diversificadas, mas eram fundamentalmente dedicadas à ficção científica e à fantasia. Surgida durante os anos 1920, a literatura pulp constrói o germe do que posteriormente seria conhecido como fandom (fusão das palavras fan e kingdom). Entre os fandoms que se desenvolviam em torno de diversas publicações, a da EC comics era particularmente forte. Diversos artistas publicaram suas primeiras histórias nessas revistas de fã. Robert Crumb e seu irmão Charles, por exemplo, eram membros ativos do fandom da $E C$, e chegaram a publicar artesanalmente diversas revistas em quadrinhos, como Arcade e Foo, que embora apresentassem histórias inéditas e circulava entre os leitores da $E C$. A diferença entre essas publicações e imprensa alternativa surgida nos anos 1960 é que o offset proporcionava uma impressão de qualidade profissional em tiragens pequenas de 5 ou 10 mil exemplares. Essa impressão por demanda diminua os riscos financeiros e permitia um fluxo contínuo de reedições. Nesse sistema, títulos populares como Zap Comix e The Fabulous Furry Freak Brothers alcançaram tiragens de milhões de exemplares (SKINN, 2004, p.132). A distribuição desses quadrinhos utilizava-se do sistema prévio de comercialização de pôsteres psicodélicos, vendidos principalmente em head shops, lojas especializadas em produtos para consumo de drogas. Assim, o comix conseguia atingir diretamente o público hippie ao mesmo tempo em que evitava completamente as sujeições do Comic Code.

A new art movement began in San Francisco, an acid-inspired style that celebrated the gatherings of the new tribes. Psychedelic posters, promoting rock concerts at ballrooms in the Bay Area, tried to express the experience of tripping on LSD with organic designs and vibrating colors. They quickly became recruiting posters for the hippie lifestyle and reached far beyond the audience for the concerts that they advertised. It was the production and distribution of ballroom posters that created the infrastructure for San Francisco to become the center of the underground commix industry (ROSENKRANZ, 2002, p.39)

A publicação em pequena escala e o surgimento da imprensa alternativa desvinculou a produção de quadrinhos do aparato das grandes editoras, possibilitando a exploração de temáticas ligadas ao universo da contracultura da época, como a revolução sexual, o movimento hippie, feminismo radical, o uso recreativo de drogas 
psicodélicas, a religiosidade de influência oriental, o movimento pelos direitos civis, rock'n'roll, grupos políticos radicais e subculturas jovens, como motoqueiros e surfistas. Conforme Rosenkranz,

Underground cartoonists reflected their upbringing and environment. They were a generation weaned on television, comic books, and rock music, politicized by Asian war and a generation gap five miles wide, and psychedelicized by lysergic acid (ROSENKRANZ, 2002, p.4).

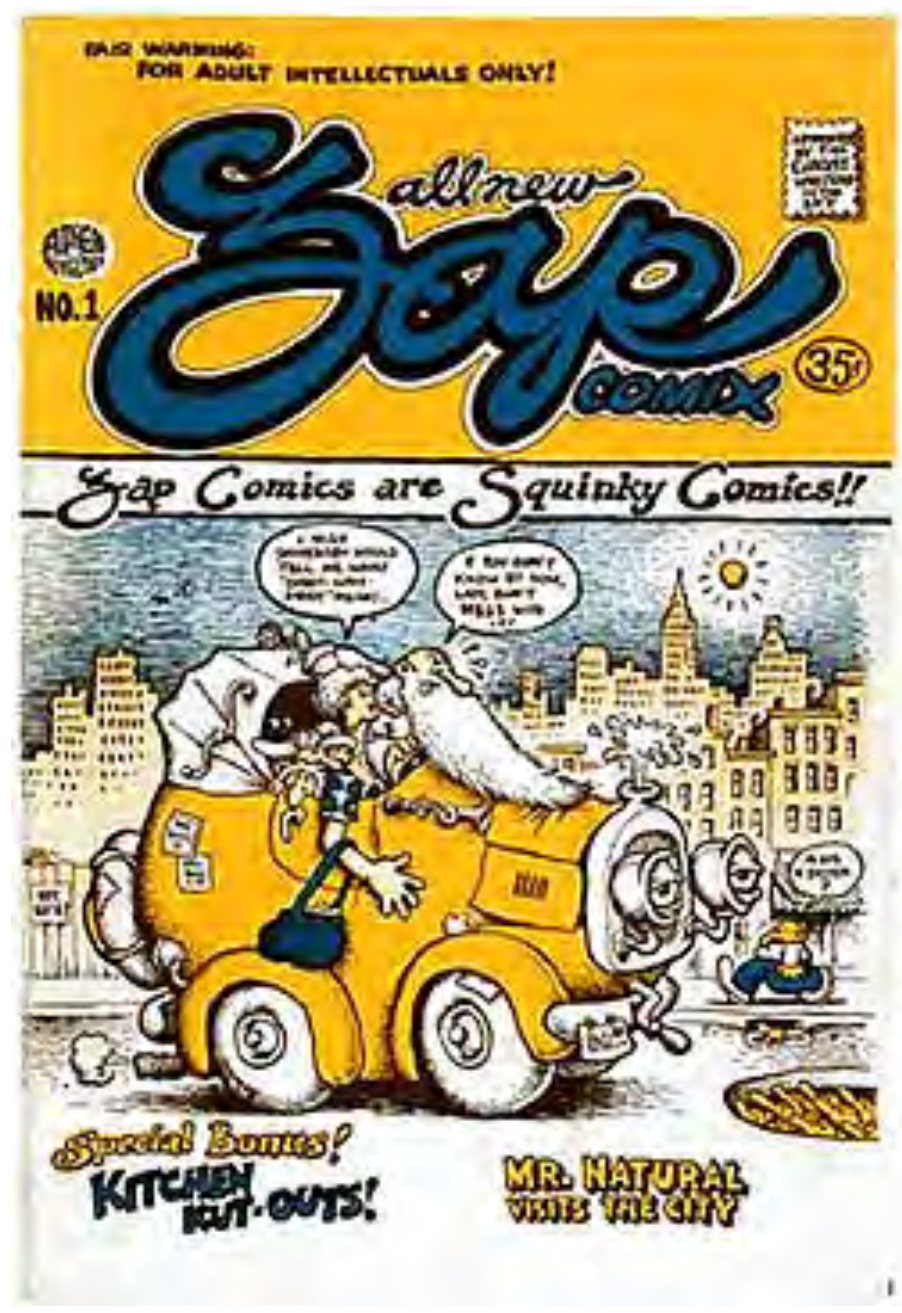

Figura 2 - Zap Comix n ${ }^{\circ} 1$

Essa modificação na sensibilidade e na própria formação cultural dos quadrinhistas underground, centrados mais em manifestações populares que na 
tradição letrada clássica, dota esses artistas de perspectiva mais ampla e positiva das possibilidades formais do meio quadrinhos. As inovações do comix são resultado desse novo regime de sensibilidade.

Segundo Rosenkranz, é difícil delimitar com clareza quando os quadrinhos underground surgem, bem como o primeiro exemplar dessa tradição. Mesmo assim o autor aponta duas obras que poderiam ser consideradas fundadoras: The Cartoon History of Surfing (1963), de Rick Griffin; e The Adventures of Jesus (1964), de Frank Stack. Partindo de outra perspectiva, mais centrada em questões formais que no caráter independente da publicação, Dez Skinn (2004, p.15) destaca que muitos elementos dos comix já podem ser encontrados em obras anteriores, como Little Annie Fanny, de Harvey Kutzman e Will Elder.

Independentemente da paternidade e dos antecedentes, o comix começa efetivamente a ser reconhecido como um movimento a partir da publicação da revista Zap Comix, em 1968

Late in 1967, Robert Crumb made the bold move that would set everything in motion. In a two-month burst of creative fervor, he conceived and drew Zap Comix, which became the prototype and inspiration for the dozens of underground comic books that quickly followed (ROSENKRANZ, 2002, p.65).

Essa primeira edição da Zap, totalmente produzida por Robert Crumb, converteu-se num surpreendente sucesso comercial. As edições seguintes já incorporaram outros artistas, fechando o grupo em torno de S. Clay Wilson, Gilbert Shelton, Rick Griffin, Robert Willians, Manuel Spain e Victor Moscoso, na edição número 4 (ROSENKRANZ, 2002).

A identificação entre a Zap e leitores ligados à contracultura foi imediata. Embora os quadrinhos não fossem uma mídia estranha para a cultura hippie, a Zap oferecia uma experiência completamente sincronizada com seus anseios, construindo representações culturais vigorosas, repletas de sexo, violência, experiências psicodélicas e desrespeito à lei e à ordem. Entre os aspirantes a quadrinhistas, a influência da Zap Comix foi ainda mais intensa, como atesta Rosenkranz: 
Zap Comics was the spark that brought together a nucleus of artists and publishers in San Francisco in 1968. Within five years, there were more than 300 new comic titles in print and hundreds of peoples calling themselves underground cartoonists. Print Mint, Rip Off Press, and Apex Novelties couldn't print comic books fast enough to satisfy their customers (ROSENKRANZ, 2002, p.4).

Embora a Zap tenha se fechado para novos colaboradores em 1969, sua influência teve um grande efeito catalizador, atraindo novos talentos para a cena underground, estimulando novos projetos de quadrinhos e, principalmente, provando a viabilidade comercial do comix

Unlike the overground market, which produced continuing comic titles on a regular schedule, the undergrounders came up with new titles all the time, and deadlines were a more casual affair. The booming counterculture population embraced comix enthusiastically, and many titles became big sellers, crunching the kinds of numbers that Marvel and DC were used to. (ROSENKRANZ, 2002, p.123).

O mercado de quadrinhos underground continuou em ascensão até 1973, quando a no caso Miller v. California Suprema Corte dos Estados Unidos decidiu que as comunidades locais poderiam deliberar autonomamente o que poderia ser considerado obsceno. A relação entre censura e pornografia nesse país sempre foi bastante controversa, polarizando as tensões entre a liberdade de expressão e pressupostos morais. A história de processos, litígios e censura, que engloba figuras centrais do mercado editorial como Bernarr MacFadden, Lawrence Ferlinguetti e Hugh Hefner, normalmente priorizava o direito à livre expressão. A manobra do estabelecimento dos padrões locais de obscenidade funcionou como um estratagema que prejudicava o elo mais fraco da cadeia editorial: o proprietário dos pontos de vendas. Cada comunidade poderia determinar seus padrões, mas não poderia iniciar um processo contra um artista ou editor fora de sua jurisdição; a posse e o comércio do material considerado ofensivo configuraria o crime. Não sabendo o que era seguro vender, os proprietários começaram a evitar qualquer material questionável. Dessa forma, qualquer publicação controversa poderia ser censurada de forma muito 
eficiente, sem prejudicar o autor ou ferir a Primeira Emenda da Constituição dos Estados Unidos, que proíbe o congresso de infringir seis direitos fundamentais, entre eles a liberdade de expressão.

O comix foi um movimento artístico de grande importância para o desenvolvimento do potencial expressivo da mídia quadrinhos, principalmente quando comparado com o estado de estagnação do mercado pós-Comic Code. Segundo Witek

Comic books have suffered as an artistic form from this virulent cultural hostility; the reactionary restrictions of the comic-book industry's self-censoring body, the Comics Code Authority, led to the thematic stagnation of the sequential art medium for several decades (WITEK, 1989, p.7).

Utilizando as categorias recorrentes do humor subversivo, violência gráfica e sexo explícito, os quadrinhos underground abordavam à sua maneira qualquer tipo de gênero tradicional da indústria, como os funny animals, aventura, policial, superheróis, etc. Contudo, a grande inovação perpetrada pelo comix acontece com o surgimento do gênero autobiográfico. 


\subsection{Autobiografia em quadrinhos}

Os quadrinhos são uma mídia que, por sua própria natureza, sempre comportou manifestações de autorepresentação. Diversos autores utilizam a metalinguagem como possibilidade expressiva, de forma que não é incomum encontrar representações pictográficas do artista interagindo com suas criações ou alusões à existência do autor. Donald Crafton já identifica esses processos na série pioneira Little Nemo in Slumberland, de Winsor McCay

When Nemo, Flip, and Impy were locked out of Slumberland in December 1907, and were very hungry, they ripped up the border lines and used the to knock down letters of the masthead [...]. Flip says "that will teach the fellow who drawn us a lesson," and Nemo responds that he is "hungry enough to eat the whole [comic] supplement." McCay conceived these jokes in the spirit of fun, but in addition to inadvertently showing his egotism by reminding the readers of his presence, the reflexive qualities also strikes us a very modern distancing effects analogous to contemporaneous cubist strategies (CRAFTON, 1982, p.129).

Embora também se concentre na presença do autor na narrativa, a experiência da autobiografia em quadrinhos diverge completamente desses exercícios de metalinguagem. Philippe Lejeune define a autobiografia como uma "narrativa retrospectiva em prosa que uma pessoa real faz de sua própria existência, quando focaliza sua história individual, em particular a história de sua personalidade" (2008, p.14). Com alguma ironia Lejeune chama atenção para o fato de que essa definição aproxima-se da encontrada no dicionário, acrescentando que a autobiografia é uma modalidade narrativa que engloba diversas manifestações, como diários, memórias, confissões, determinadas construções epistolares, blogs, etc. Embora não cite nominalmente sua contraparte quadrinizada, essa definição de autobiografia é ampla o suficiente para comportar também essa manifestação. Outra particularidade acerca do conceito de autobiografia é que ele diz respeito mais ao caráter não-ficcional dessa narrativa que a características estéticas/formais do que se poderia definir como um estilo ou modelo autobiográfico. "O que define a autobiografia para quem a lê é, antes de tudo, um contrato selado pelo nome próprio" (2008, p.33). Isto é, quando se 
trata da autobiografia, o pacto desenvolvido com o leitor é mais importante que características formais da obra. Assim, muitas vezes o que diferencia uma narrativa autobiográfica de um romance em primeira pessoa é a correspondência entre o nome da personagem e o autor, indivíduo cuja existência real pode ser comprovada no âmbito jurídico. Lejeune acrescenta ainda que "para que haja autobiografia [...], é preciso que haja relação de identidade entre o autor, o narrador e o personagem" (2008, p.15). Logo, obras com supostos ou deduzíveis elementos autobiográficos não se encaixariam nessa tradição. "A autobiografia não é um jogo de adivinhação, mas exatamente o contrário disso" (2008, p.26).

No caso específico dos quadrinhos, essa relação de identidade pode ser mais facilmente determinada, considerando a informação gráfica inexistente na prosa. Nos quadrinhos autobiográficos, além das marcas da narrativa em primeira pessoa, que sozinhas não poderiam desambiguizar o caráter do relato, ainda é possível identificar a presença do autor marcada em termos pictográficos. Uma vez determinada a semelhança entre a personagem retratada e a aparência do autor, a relação de identidade será delimitada. Mesmo nos casos onde não existe uma semelhança mensurável entre o autor e sua representação pictográfica, ou ainda quando o estilo do artista é tão simplificado que impede que se estabeleça uma relação de semelhança, a repetição constante acaba por funcionar como índice de reconhecimento. Esses autorretratos individualmente já funcionam como um elemento de representação da identidade do artista, muitas vezes exteriorizando elementos de sua personalidade.

Embora nossa perspectiva teórica considere os quadrinhos como uma expressão artística e cultural cuja tradição delimita o primado do autor como força motriz do processo de criação, acreditamos que o surgimento e ascensão da autobiografia se relaciona com outras modalidades de expressão artística e processos sociais complexos. Assim, tomando como diretriz o pacto autobiográfico, para utilizar a terminologia proposta por Lejeune, e a relação de identidade entre autor, personagem e narrador, confirmamos a proposição anterior que relaciona o surgimento dos quadrinhos autobiográficos e o movimento artístico comix. Tento estabelecido essa relação, é importante destaque que durante o auge do comix, a representatividade dos quadrinhos autobiográficos ainda era muito limitada, principalmente se comparado aos gêneros mais populares, como sátiras sexualmente explícitas e aventuras humorísticas envolvendo o consumo de drogas. Com o 
processo de desarticulação da imprensa alternativa, iniciado em 1973, a autobiografia tornou-se uma modalidade praticada por um número crescente de artistas. Em muitos sentidos, a autobiografia beneficiou-se do vácuo deixado pelo comix, ocupando seu lugar com narrativas mais socialmente aceitas. Segundo Witek (1989, p.153) "The underground commix forever artificially imposed cultural constraint, but the willfully adversarial and transgressive stance of the commix ensured that they would remain at the fringes of the culture at large". A autobiografia, por outro lado, é um gênero que encontrou respaldo como manifestação culturalmente relevante.

No início da década de 1970 alguns quadrinhistas iniciaram experimentos autobiográficos, normalmente com narrativas de poucas páginas. $\mathrm{O}$ trabalho de Crumb, Green e Spiegelman se destacam como fundadores dessa modalidade narrativa. Contudo, o primeiro exemplar do que realmente pode se definir (GRAVETT, 2005, p.23) como matriz autobiográfica dos quadrinhos estadunidenses é o Binky Brown meets The Holy Virgin Mary (Figura 3), de Justin Green. Numa época em que os quadrinhistas underground primavam pelas formas narrativas mais curtas, que podiam ser levadas a cabo rapidamente, Green passou quatro anos (19691972) desenhando minuciosamente as 44 páginas de Binky Brown, um número consideravelmente extenso para a época, conforme atesta Art Spiegelman: "Today a forty-four-page work might seem like only a throat-cleaning exercise for some Young whippersnapper's 500-page 'graphic novel', but back in The Day, forty-four pages was a epic" (2009, p.3). Além de sua extensão, outro fator que se destaca na obra é o esforço que Green despendeu para construir uma narrativa rica em detalhes e com uma orientação temporal rígida. A história acompanha a infância e adolescência do jovem Binky, sempre às voltas com suas fantasias sexuais, culpa católica e transtorno obsessivo compulsivo.

Binky Brown meets The Holy Virgin Mary recounts Green's problems in decoding and assimilating the conflicting demands of puberty, religious fervor, and secret personal rituals. That such material could be mined for yuks and bucks had not been considered before, and there are laughs aplenty in this tortured tale of teenage turmoil (ROSENKRANZ, 2002, p.188). 

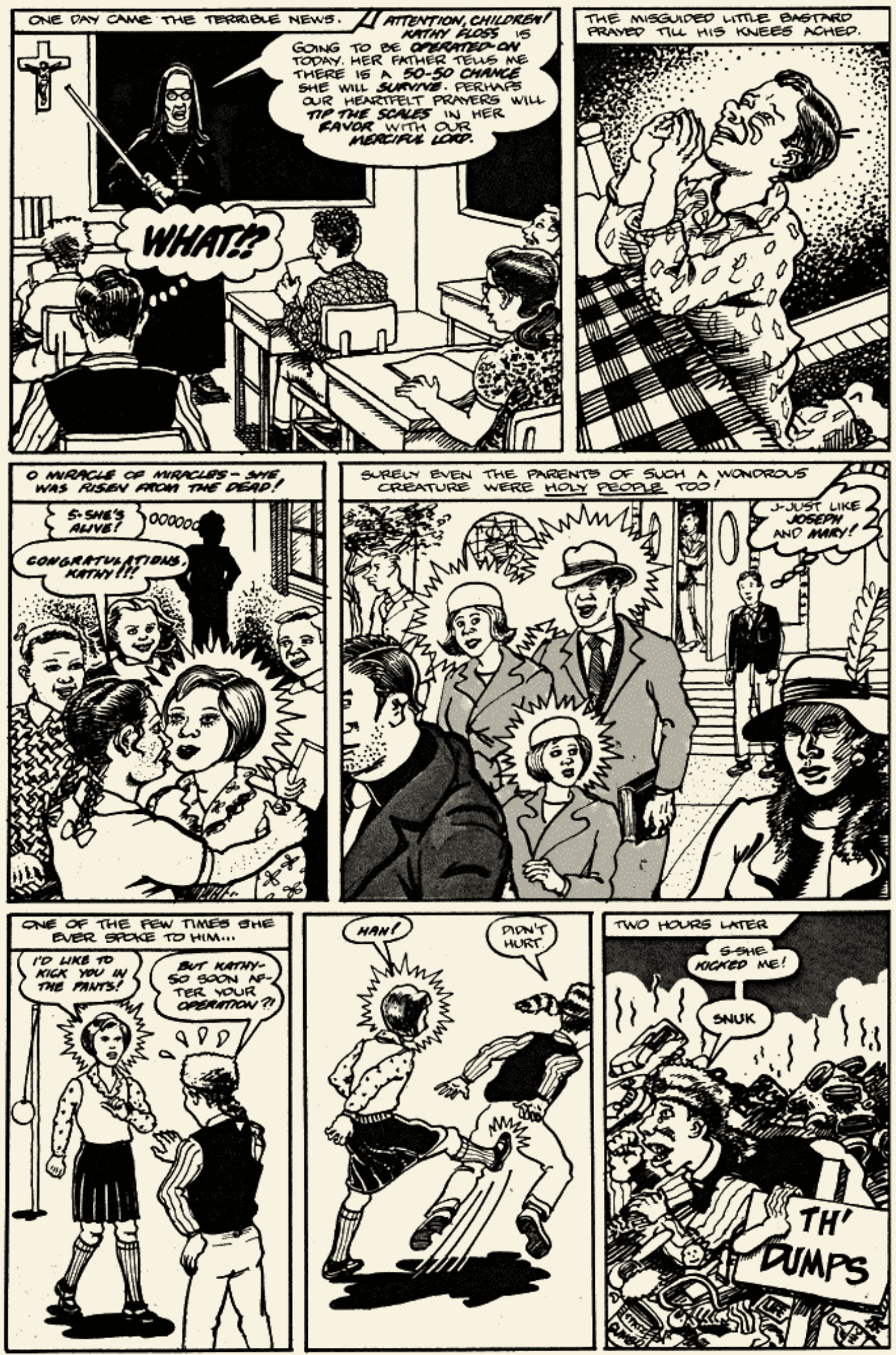

Figura 3 - Binky Brown, de Justin Green 
A papel de Binky Brown como um dos fundadores da autobiografia é ressaltado por historiadores dos quadrinhos como Rosenkranz (2002, p.171), Gravett (2005, p.23) e Skinn (2004, p.142), mas existe um problema no que se refere à relação de identidade entre autor, personagem e narrador, já que esse quadrinho é narrado em terceira pessoa e a personagem chama-se Binky. Considerando que essa obra é a primeira de uma tradição é natural que apresente divergências em relação ao modelo tradicional de autobiografia e ao modelo praticado nos quadrinhos. Mas se considerarmos o contexto e as declarações do autor, podemos perceber que um pacto autobiográfico é construído, mesmo que por vias diversas. Além disso, no caso específico dos quadrinhos, a informação gráfica desempenha a função de índice de reconhecimento de forma tão eficiente que muitas vezes prescinde da relação estabelecida pelo nome próprio. Witek identifica esse fenômeno na série American Splendor, de Harvey Pekar

Many of the stories do feature a protagonist named "Harvey Pekar," but Pekar also adopts a number of fictionalized autobiographical personae, including "Herschel," "Our Man," and "Jack the Bellboy." The Pekar character is recognizable by his distinctive characteristics; he is darkhaired with sideburns (and in the later issues a receding hairline), casual if not downright slovenly in dress, usually stoical in expression, and he works at what the persona often calls a "flunky job" (WITEK, 1989, p.123).

Conforme Green (2009, p.58), a escolha do nome Binky Brown remete diretamente à tradição dos quadrinhos, fazendo referência à icônica personagem Buster Brown, de Richard F. Outcault. Além disso, "The very title of the work was a conscius nod to S. Clay Wilson. The word 'meets' is in reference to Rudy and the Dykes Meet the Pirates. The active verb guarantees conflict, or reconciliation of opposites" (GREEN, 2009, p.57).

Green aponta ainda outra explicação para a criação de Binky Brown. Boa parte da história aborda o problema do autor com estranhos rituais, obsessão e crenças irracionais. Green sofre de transtorno obsessivo-compulsivo, um tipo de distúrbio de ansiedade que não havia sido descoberto nos anos 1960. O autor foi, portanto, tratado com sessões de psicoterapia comum. Essas sessões o levaram ao estudo da obra de Carl Jung, onde Green procurava uma chave para o tratamento do 
seu problema, concretizado na criação de seu doppelganger Binky. "In Jung's parlance, Binky was my 'Shadow', my hidden self, wich had beneficial as well as destructive potential (GREEN, 2009, p.57). Binky, portanto, possui uma relação direta de identidade com Green, embora o autor use alguns dispositivos narrativos para abordar sua psique com algum distanciamento. Essa relação de identidade também é reforçada pelo fato de Green sempre ter admitido que Binky Brown era sua autobiografia, de modo que mesmo que embaralhe as relações de identidade, a obra constrói um pacto autobiográfico com o leitor.

A influência de Binky Brown sobre o futuro trabalho de artistas como Crumb, Spiegelman e, numa perspectiva mais ampla, todos os quadrinhistas norteamericanos que enveredam pela escrita íntima é destacada por diversos autores. Segundo Gravett, "Without Binky Brown, Maus would not exist, and both in turn have inspired more cartoonists to deal with their early experiences and their aftereffects" (2005, p.23). É interessante destacar que no início da década de 1970 a maioria dos quadrinhistas ligados aos comix mantinham relações de amizade e, não raramente, se encontravam para discutir os trabalhos em andamento (ROSENKRANZ, 2002). Isto explica porque, quase concomitantemente à publicação de Binky Brown, Robert Crumb e Art Spiegelman começaram a produzir histórias em quadrinhos autobiográficas. Spiegelman, por exemplo, sempre destacou a massiva influência da obra de Justin Green sobre sua obra, conforme relata Rosenkranz:

In 1972, Justin Green finished drawing Binky Brown meets The Holy Virgin Mary, his personal thesis on pubescent psychological trauma. His fellow cartoonists and perceptive comic readers all over the globe recognized this book immediately as a major innovation. "What the Brontë sisters did for Gothic romance, what Tolkien did for Sword-and-Sorcery, Justin did for confessional autobiographical comix, a real growth industry in the Independent Comix biz," said Spiegelman”. [...] Watching Binky Brown as it was created led Spiegelman to examine his own psychological fountainhead. "l'll never forget seeing the unpolished pages of Binky Brown hanging from a clothesline stretched around the drawing table and all through his living room back in 1971 and knowing I was seeing something new get born" (ROSENKRANZ, 2002, p.188). 

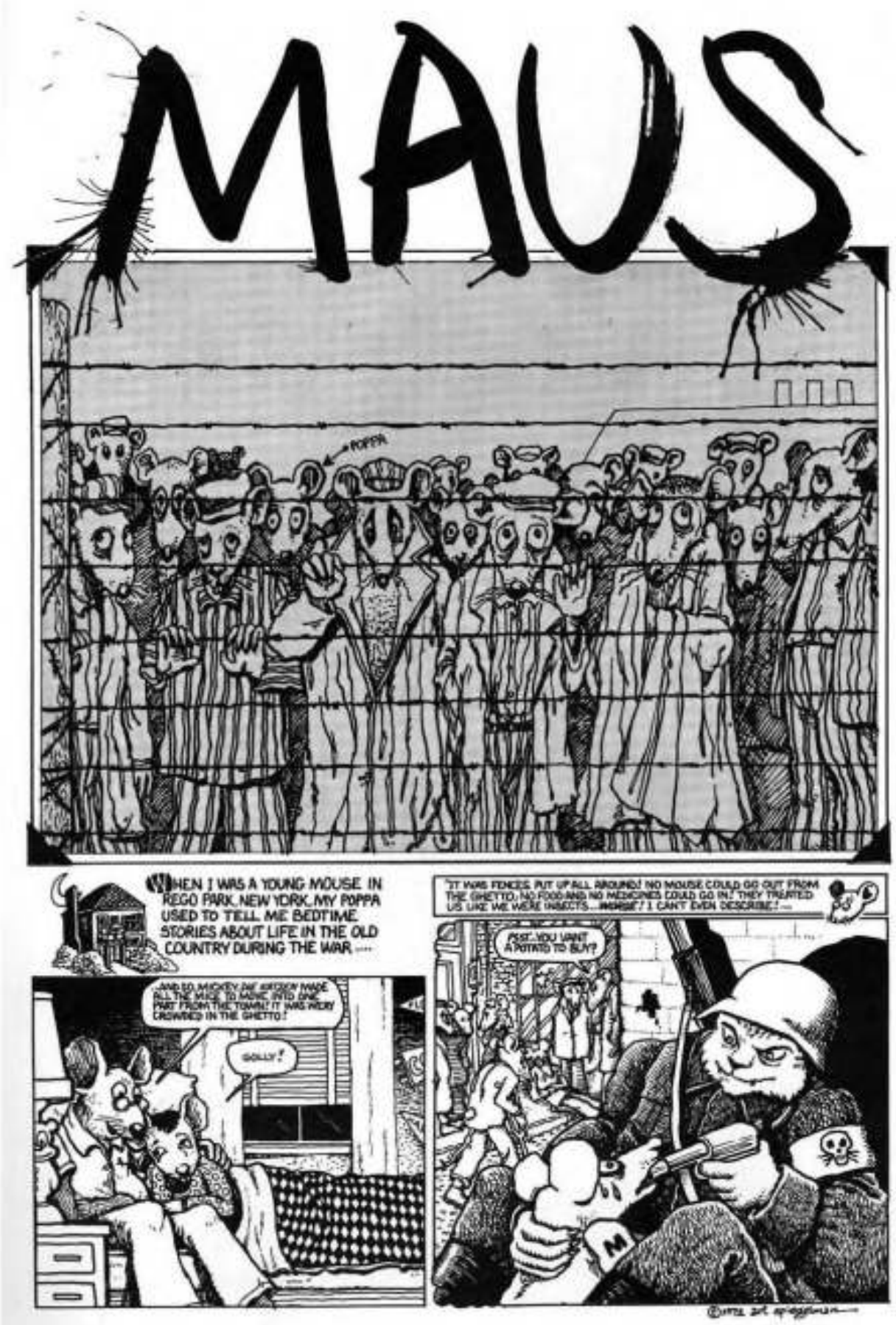

Figura 4 - Primeira versão de Maus, de Art Spiegelman

Os primeiros quadrinhos de Art Spiegelman eram fortemente influenciados pelos autores ligados à Zap Comix e orientavam-se prioritariamente em função do humor e da exploração da metalinguagem. A partir de 1972 Spiegelman envereda pela expressão autobiográfica, abordando eventos de forte carga emocional numa história de três páginas intitulada Maus. Nesse quadrinho Art Spiegelman revisita sua infância e as terríveis histórias contadas por seu pai, Vladek Spiegelman, judeu polonês 
sobrevivente do holocausto. Relacionando-se com as fábulas e a tradição do funny animals, Art utiliza-se do interessante recurso gráfico e narrativo de representar os judeus como ratos e os alemães como gatos (Figura 4). Segundo Gravett, essa metáfora fazia muito sentido "because Hitler compared Jews to vermin and used ratpoison Zyklon B in the death camps" (2005, p.60). Considerando que os comix se caracterizavam por sua abordagem humorística e satírica, mesmo quando tratavam de problemas sociais sérios, Maus se destacou pelo tom sóbrio e dramático da narrativa.

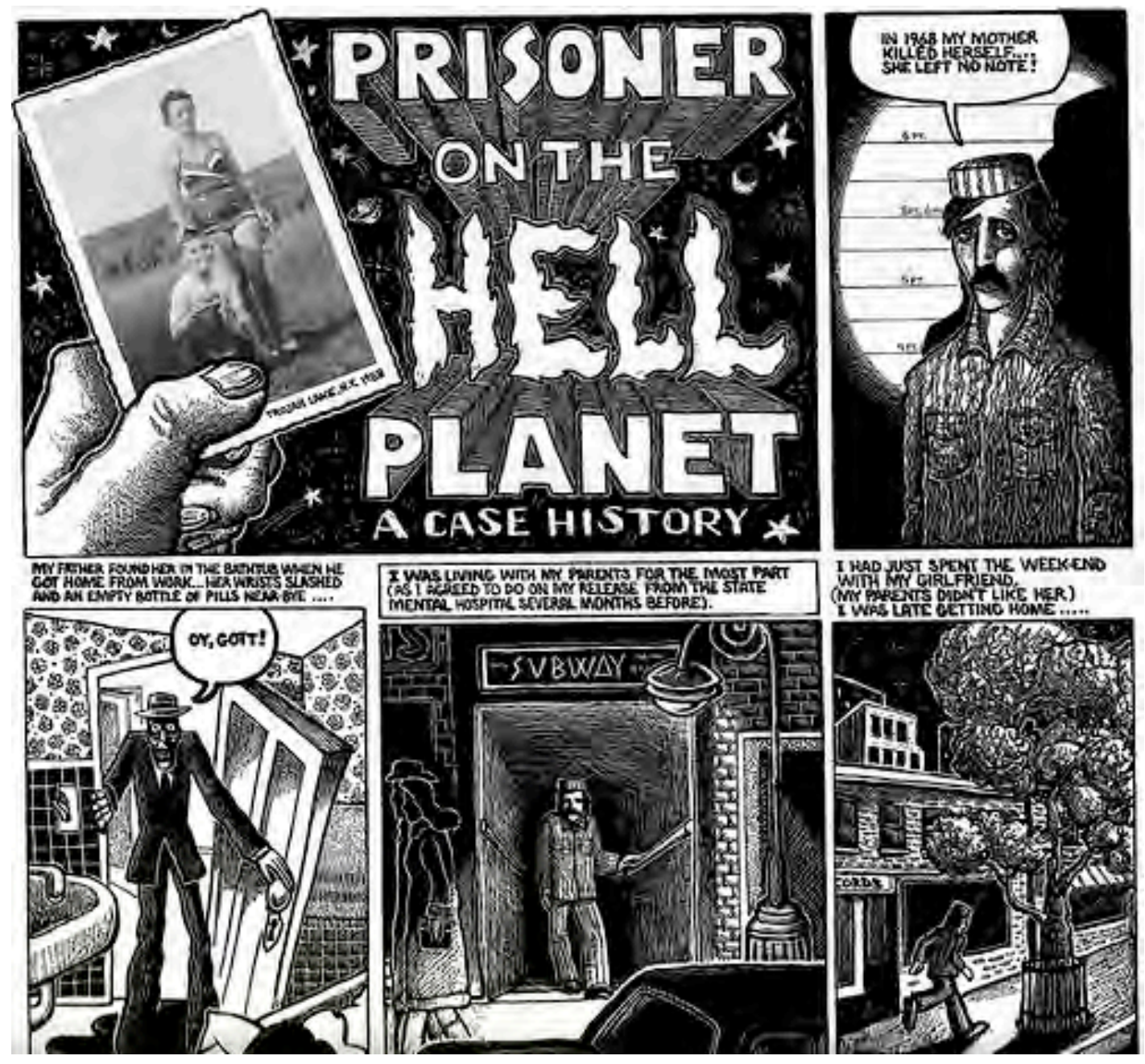

Figura 5 - Prisioner on the Hell Planet

Em sua próxima história autobiográfica, Art Spiegelman aborda um tema igualmente dramático de sua vida familiar: o suicídio de sua mãe. Prisioner on the Hell Planet (Figura 5) é um breve ensaio sobre as impressões psicológicas e trauma causado pela perda da figura materna. A configuração pictográfica dessa história em quadrinhos, que remete à arte expressionista, transmite de forma indelével a 
impressão de distorção psicológica e emoções afloradas. Assim como Justin Green, Spiegelman utiliza-se dos quadrinhos para explorar os recantos mais profundos de sua vida interior, exteriorizando traumas e revivendo eventos importantes para a formação de sua personalidade.

Nos anos seguintes, vários quadrinhistas seguiram a trilha aberta pelos pioneiros Justin Green, Robert Crumb e Art Spiegelman. Criadores como Harvey Pekar, Alison Bechdel, Chester Brown, Aline Kominsky Crumb e David Small produzem autobiografia como modalidade expressiva preferencial. Embora a autobiografia não represente uma fatia considerável do mercado de quadrinhos, o prestígio de que gozam não é encontrado em nenhum outro gênero. É cada vez mais comum que autobiografias em quadrinhos ganhem prêmios literários (Maus ganhou o Pulitzer Prize em 1992 e Palestine, de Joe Sacco, o American Book Awards em 1996, por exemplo) e apareçam na lista de melhores publicação do ano de revistas culturais como The Village Voice e The New Yorker. 


\section{CAPÍTULO II - A ESTRUTURA DA AUTOBIOGRAFIA EM CRUMB}

\subsection{Robert Crumb e os quadrinhos autobiográficos}

Robert Crumb publicou seu primeiro trabalho profissional em janeiro de 1965, na Help no 22. Essa revista, editada por Harvey Kutzman, trazia duas obras do autor: Harlem e Fritz Comes on Strong. A primeira é um tipo de construção gráfica atípica na produção de Crumb, já que se constitui como uma série de ilustrações e rascunhos de cenas da vida urbana permeados por comentários humorísticos (figura $6)$.
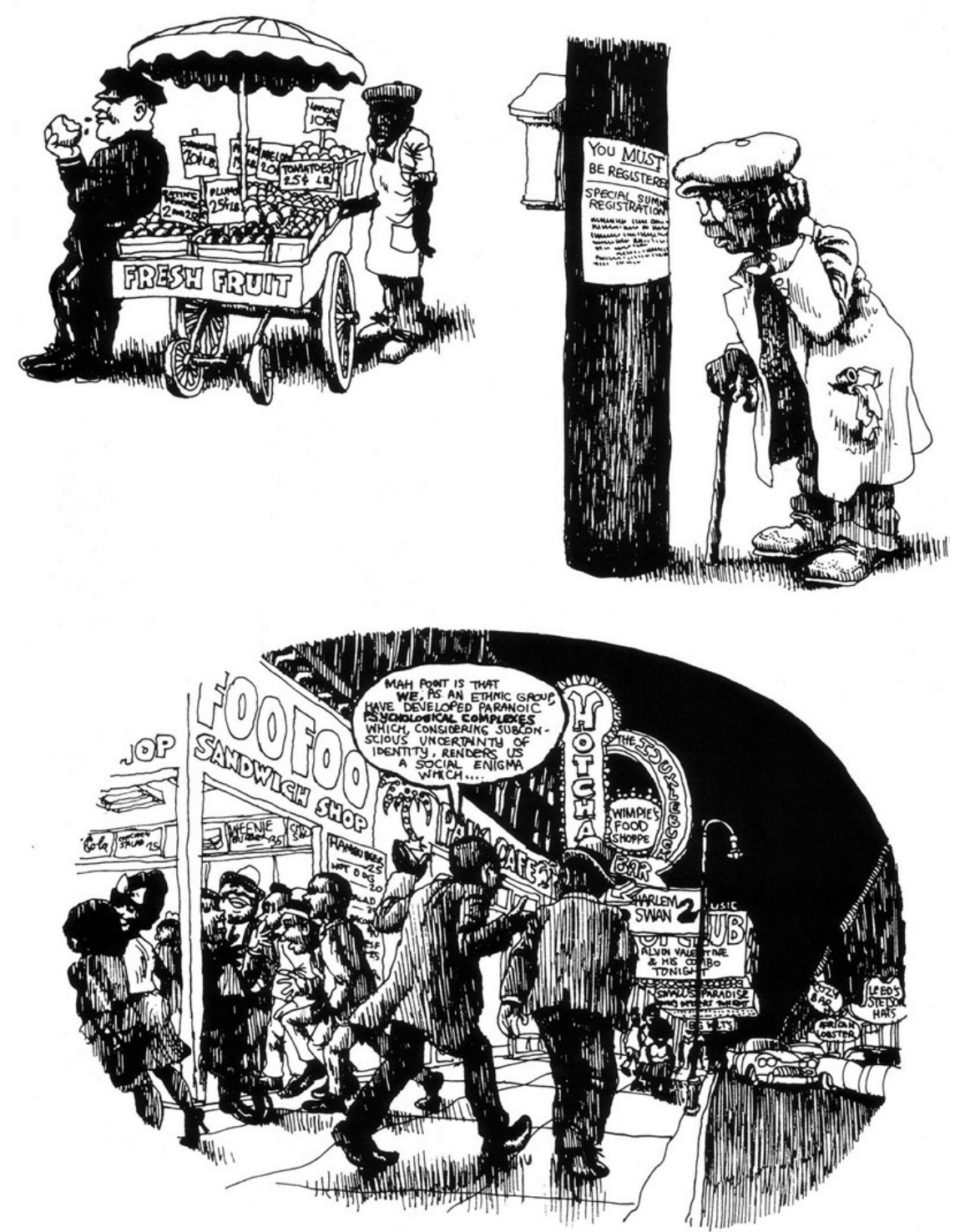

Figura 6 - Harlem 
Fritz Comes on Strong, por outro lado, é um autêntico representante do estilo de narrativa pelo qual o autor é reconhecido. Nessa história acontece uma interessante subversão do gênero dos funny animals. Se lida individualmente, a primeira página (figura 7) aparenta ser uma típica história de animais antropomórficos ao estilo Disney ou Pat Sullivan, mas na página seguinte Fritz continua a tirar a roupa da gata até que ela fique nua. O último quadrinho concentra o punch da piada, quando Fritz comenta: "Now be patient, my sweet... Them little flies are hard t'get hold of!". Nos anos seguintes as histórias de Fritz the cat alcançaram um grande sucesso de público, culminando na adaptação cinematográfica de 1972. A recorrência dessa personagem na produção de Crumb permite vislumbrar diversas transformações no estilo de narrativa nas primeiras fases da carreira do autor.

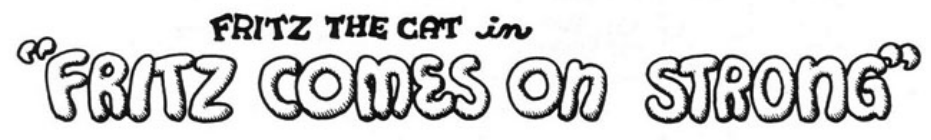
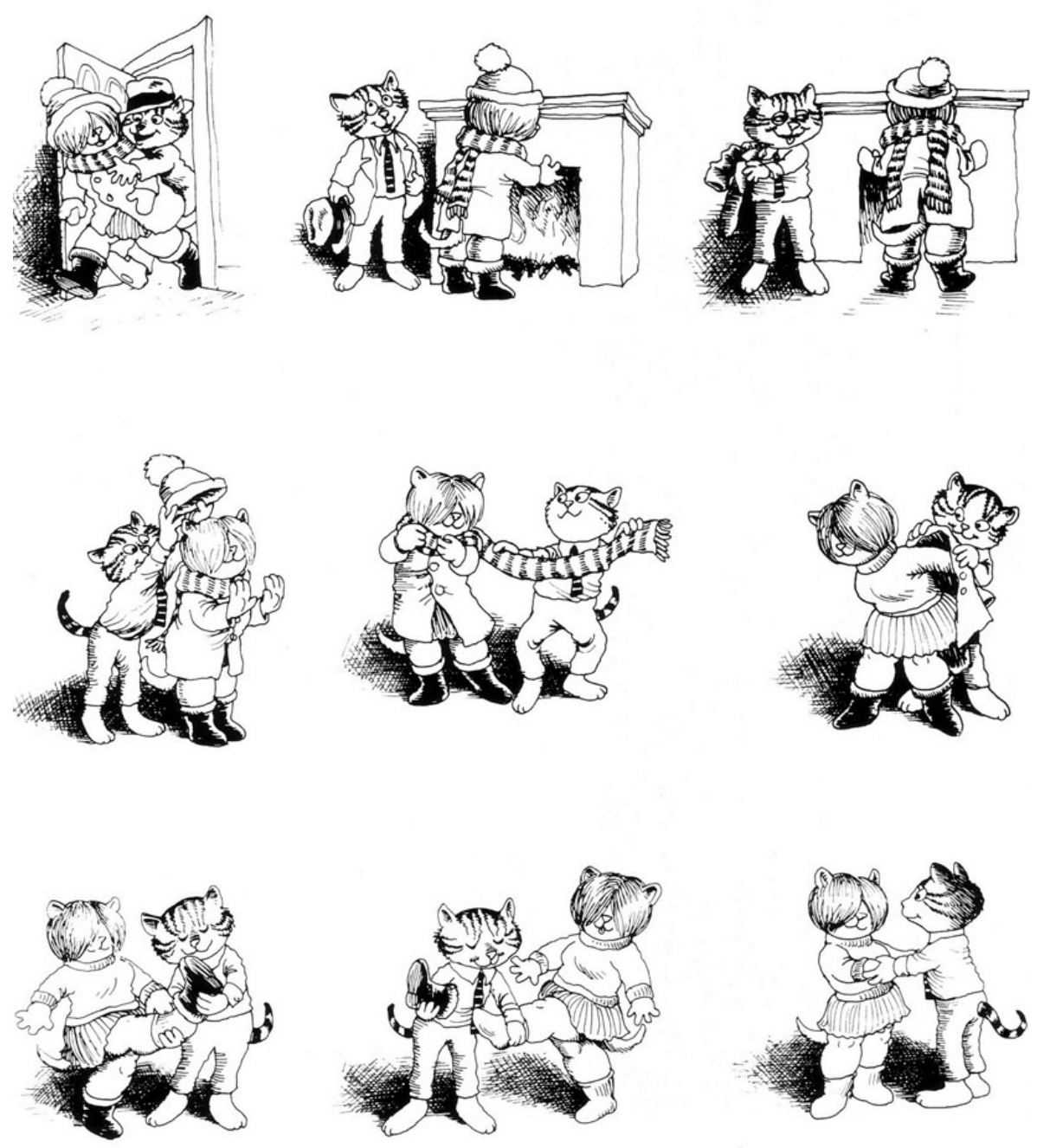

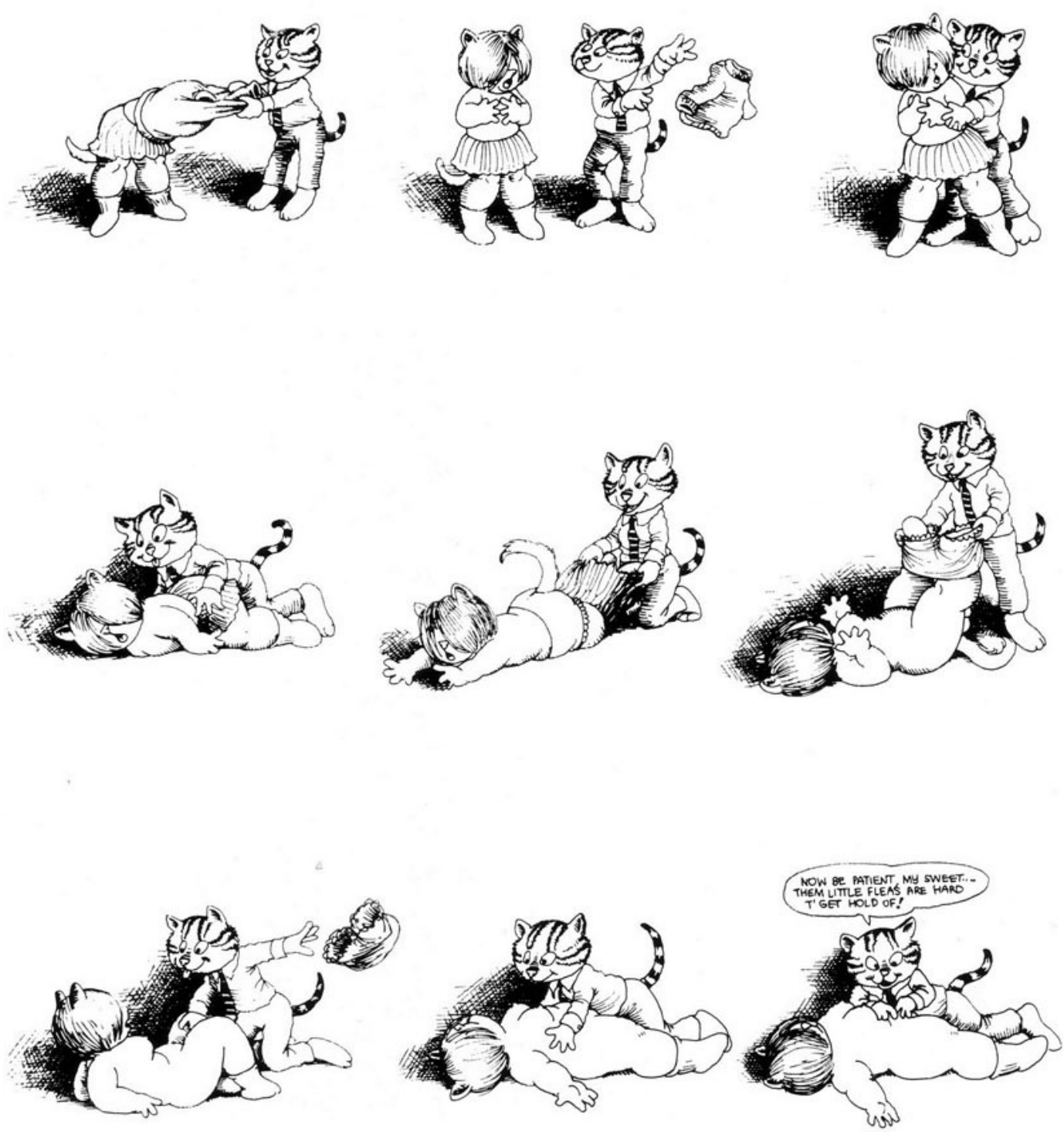

Figura 7 - Fritz Comes on Strong

Normalmente, as análises acerca da obra de Crumb (ROSENKRANZ, 2002; SKINN, 2004) iniciam com uma abordagem dos quadrinhos produzidos durante a década de 1960, o que corrobora a imagem do autor como um relutante ícone da contracultura. Entretanto, a fase amadora de sua produção revela um criador extremamente preocupado com a linguagem e os rumos do mercado de quadrinhos, aspecto bastante significativo para a compreensão de sua obra posterior. 
É difícil fazer qualquer afirmação concreta acerca da produção inicial de Crumb, já que parte desses quadrinhos se perderam. Contudo, nos dois primeiros volumes da coleção The Complete Crumb (1987 - 2005) ainda é possível encontrar mais de 200 páginas de quadrinhos amadores. Entre o material documentado, identificamos que as primeiras histórias de Fritz, the Cat datam do início da década de 1960. Fritz primeiramente aparece como personagem secundário no quadrinho Cat Life, uma narrativa inspirada nos gatos da família Crumb. Nas histórias seguintes, denominadas de forma geral como Animal Town, Fritz deixa de ser um animal de estimação, assumindo características antropomórficas. Essa série é conduzida aos moldes dos funny animals da Disney, com uma mistura de aventura e humor bemcomportado. Nessa fase amadora, é comum a tentativa de emular o estilo de outros artistas, particularmente Carl Barks e Harvey Kurtzman. A busca por modelos e o grande volume de histórias produzidas nesse período demonstram o quanto Crumb estava comprometido em compreender a técnica dos quadrinhos.

Pelo que se pode constatar nas cartas escritas a Marty Pahls e Mike Britt, o jovem Crumb tinha muito interesse em quadrinhos, tanto no aspecto formal quanto nas questões culturais envolvidas. Essas cartas, compiladas no livro Your vigor for life appalls me: Robert Crumb letters 1958-1977, são documentos importantes para compreender os anos inicias da formação do artista, bem como o modo como ele concebia o potencial criativo da mídia quadrinhos. A maior parte dessas correspondências entre amigos ligados ao fandom é composta por uma série de eventos cotidianos banais e listagem de revistas antigas garimpadas, mas alguns trechos são bastante significativos. Numa carta de 1959 endereçada a Marthy Pahls, Crumb faz um interessante relato (é importante destacar que alguns erros ortográficos das cartas foram mantidos por decisão do editor Ilse Thompson):

The librarian, as brilliant as she is, said she definitely believes Wertham in Seduction of the Innocent. I told her that I remember very clearly the days of horror and crime comics, read many of them, and had many friends who had read them, and that I saw no difference in my friends who read comics heavily (even crime and horror) than in those who didn't read any at all. I told her that Wertham grossly exaggerates many things, and that, most likely, if a kid who hangs himself didn't have the comics to look in, he probably would have killed himself some other way. Wertham had no strong argument on this point (CRUMB, 2012, p.34-35). 
Este trecho, além de exemplificar um ambiente culturalmente hostil aos quadrinhos, também evidencia uma posição crítica do autor em relação à paranoia do Comics Code Authority.

Em outras cartas, Crumb demonstra um conhecimento apurado da obra de diversos artistas gráficos e cartunistas. Uma em particular, escrita em 1961, contém uma longa explanação acerca das obras de Hal Foster, Honoré Daumier, Carl Barks, Walt Kelly e George Herriman (CRUMB, 2012, p.156-159). Antes de iniciar sua carreira profissional em 1962, como separador de cores na empresa de cartões comemorativos American Greetings, Crumb também questiona bastante acerca de em qual campo específico poderia atuar:

I'm not quite sure about my own future. I'm even little baffled. There are so many indefinity things... like the future of the cartoon industry, what the public will like, what I can do best myself... All this makes the future look rather hazy... Which is best? Comic strips? Magazines? Not comic book, unless there's a great reawakening!... Possibly the animation fields...(CRUMB, 2012, p.35).

Esses indícios atestam que Crumb não apenas estava familiarizado com a obra de diversos cartunistas, mas também tinha uma postura muito crítica em relação ao mercado e aos rumos que os quadrinhos estavam tomando. Essa fase inicial da carreira do autor, marcada pelo estudo da linguagem dos quadrinhos e pela produção contínua de histórias, permite que ele inicie sua carreira profissional como um artista já experimentado. Assim, as inovações temáticas e narrativas perpetradas por Crumb constituem-se como uma ruptura que parte de um conhecimento aprofundado da tradição dos quadrinhos.

Rosenkranz (2002, p.16) aponta a história R. Crumb Comics and Stories (figura 8), de 1964, como a primeira narrativa de Crumb que se aproxima do estilo underground. Esta história, coincidentemente protagonizada por Fritz, mostra o gato voltando para casa após uma longa ausência. Desconsiderando a narrativa pouco "aventuresca", pode-se afirmar que boa parte dessa história de nove páginas é 
conduzida aos moldes dos funny animals, exceto pelo segmento final, onde Fritz tem relações sexuais com a própria irmã. Nas histórias seguintes, como Fritz the Cat, Ace Salesman (1964) e Fritz Bugs Out (1965), o autor afasta-se ainda mais das convenções narrativas do quadrinhos tradicionais que, anteriormente, tentava emular. Enquanto nas obras anteriores existe a intencionalidade clara de construir narrativas mais rígidas, estruturadas em função da resolução da intriga, nos quadrinhos produzidos após 1964 acontece um afrouxamento na condução da trama. Fritz Bugs Out exemplifica bem essa forma de narrativa espontânea, onde ação flui livremente de tópico em tópico: em um momento está preocupado com as provas que se aproximam, no outro envolvido com militantes radicais, é perseguido pela polícia e termina buscando inspiração para sua escrita criativa na margem de um rio. Nesse período, Crumb também introduz uma série de temas relacionados ao universo social adulto, como relacionamentos afetivos experimentais, uso recreativo de drogas, crises existenciais e problemas financeiros.

Em 1966 Crumb usa LSD pela primeira vez (CRUMB, 1997, viii), dando início a uma aproximação do cenário contracultural, processo que culminaria na sua mudança para San Francisco e no lançamento da revista Zap Comix. As experiências com LSD desempenharam um papel importante no seu trabalho, que se tornou mais experimental e distorcido. Segundo Crumb,

\begin{abstract}
It was during that fuzzy period that I recorded in my sketchbook all the main characters I would be using in my comics for the next ten years: Mr. Natural, Flakey Foont, Schuman the Human, the Snoid, Eggs Ackley, The Vulture Demonesses, Shabno the Shoe-Horn Dog, this one, that one. It was a once-in-a-lifetime experience, like a religious vision that changes someone's life, but in my case it was the psychotic manifestation of some grimy part of America's collective unconscious (CRUMB, 1997, p.viii).
\end{abstract}

Entre os quadrinhistas underground, Crumb era um dos poucos artistas que continuamente conseguia apresentar novos personagens. Ao mesmo tempo em que essas criações encontravam ressonância no público, também despertava críticas severas de diversos setores da sociedade. "Crumb created a host of characters that fuelled criticism of him being sexist, racist and homophobic. The likes of Angelfood 
McSpade, Bigfoot, Whiteman, Honeybunch Kaminski and the Ruff Tuff Creampuff had their fair share of critics" (SKINN, 2004, p.84). Essa dinâmica entre o sucesso de público e críticas quando às representações sociais construídas nos seus quadrinhos é uma constante na produção de Crumb.

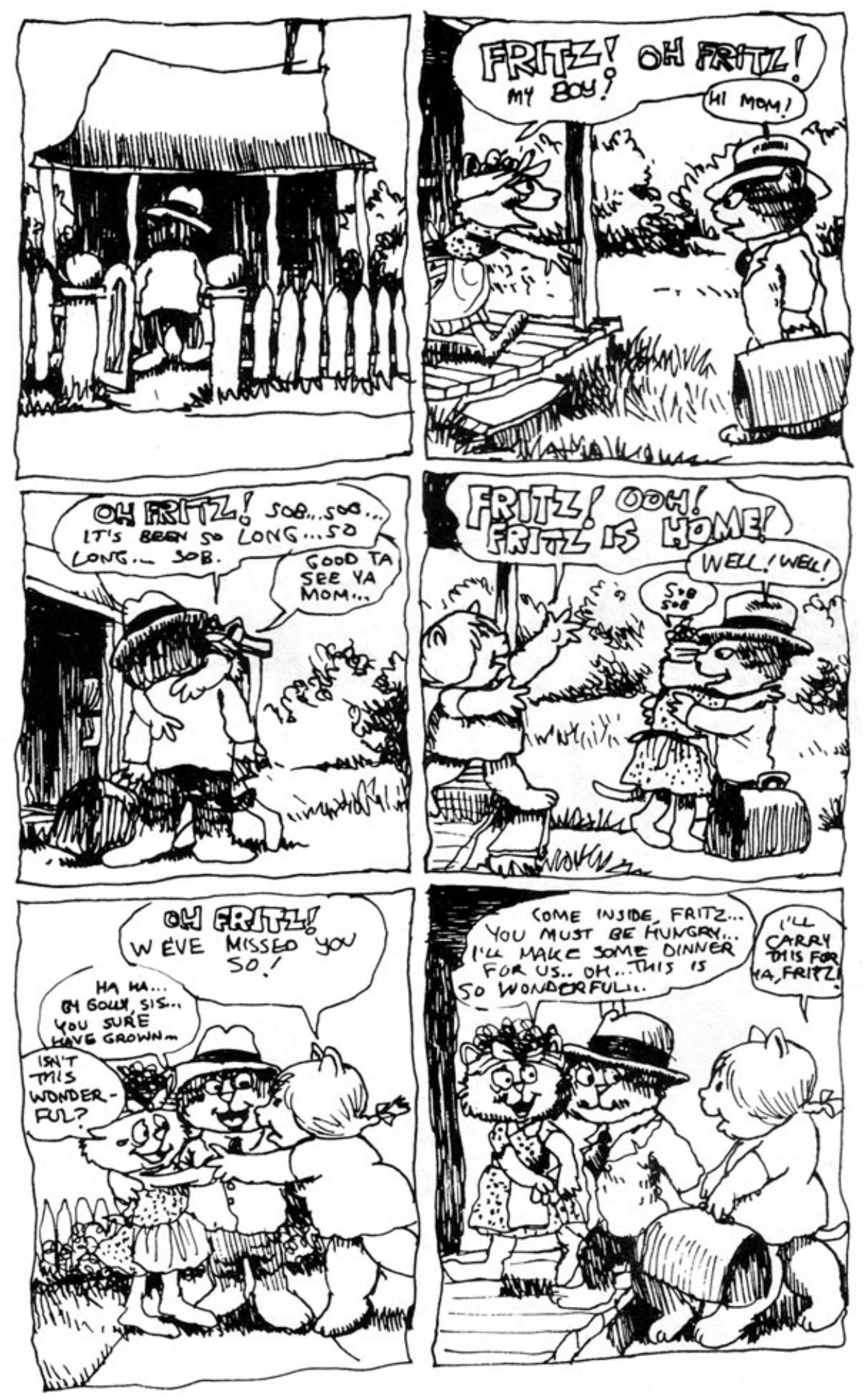

Figura 8 - Crumb Comics and Stories 

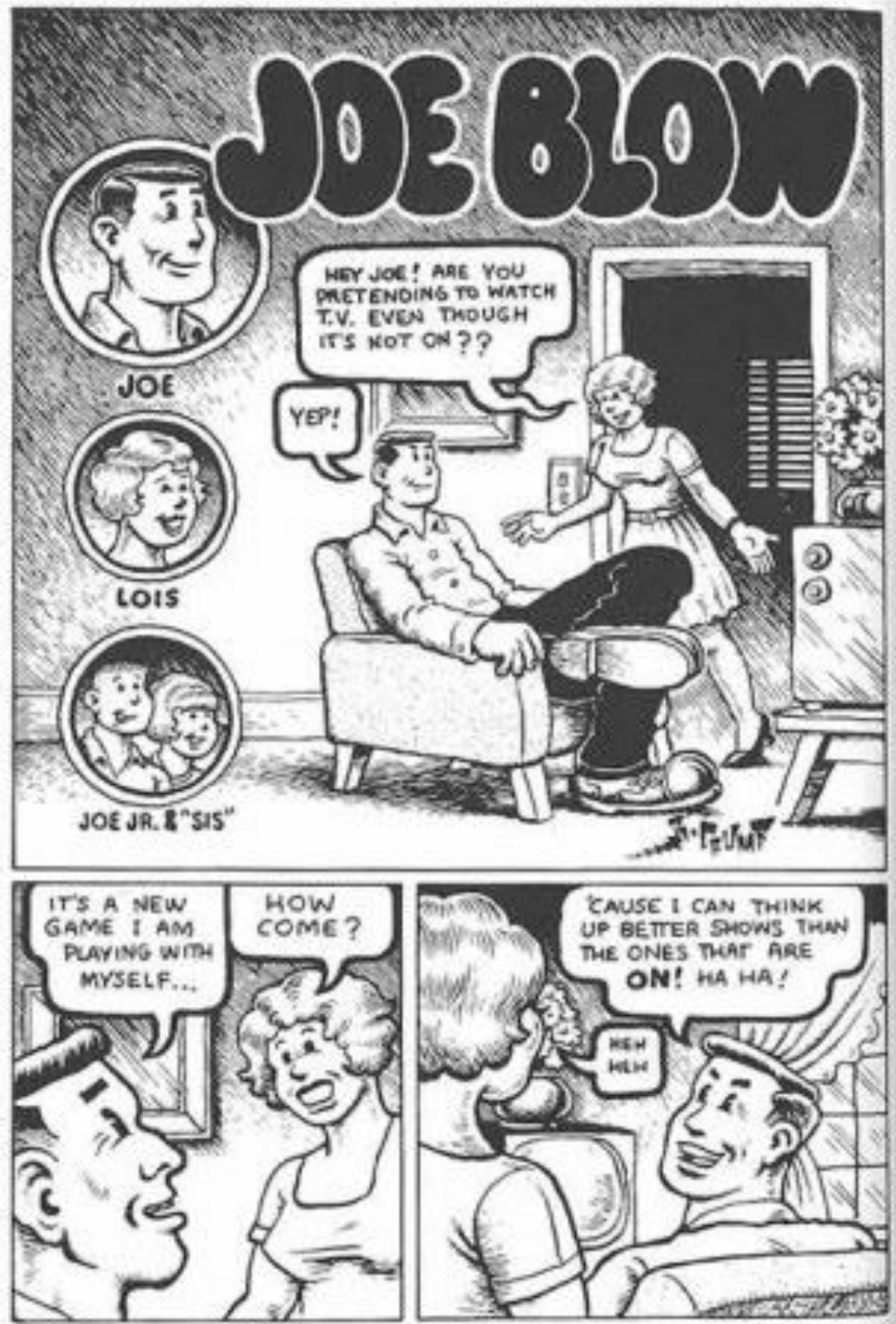

Figura 9 - Joe Blow

Juntamente com as representações pictográficas racistas (STRÖMBERG, 2003, p.7), a principal crítica à obra de Crumb diz respeito ao caráter misógino de suas criações. Em Fritz, the No-Good, publicado na revista Cavalier em 1968, já é possível encontrar imagens de violência e dominação sexual. Essas imagens tornamse mais explícitas após a publicação de Zap Comix, principalmente pela influência 
de outros colaboradores da revista: "heavily influenced by Robert Willians and S Clay Wilson - who he credits for starting off the "smut revolution" in comix - Crumb began producing material that, until then, had been the preserve of hard-core porn merchants" (SKINN, 2004, p.60). Data desse período uma série de quadrinhos e ilustrações que podem ser classificados como pornográficos, bem como a construção de um estilo característico de representação da figura feminina. Essas mulheres grandes e robustas são facilmente reconhecidas fora do universo dos quadrinhos (HANSON, 2010, p.165) e, juntamente com as ilustrações para capas de discos, contribuíram para uma maior penetração da obra de Crumb num âmbito cultural mais amplo.

Essas narrativas sexualmente explícitas atingem seu ápice na edição 4 da revista Zap Comix, com Joe Blow (Figura 9), uma trama sobre incesto que poderia figurar em qualquer revista pornográfica hardcore. Esse quadrinho em particular ocupa um lugar importante dentro da história das publicações alternativas, já que levou a um processo judicial por imoralidade. A despeito dos problemas com a justiça, Crumb continuou seu projeto de exploração da temática sexual, criando inclusive uma série de revistas temáticas, como Big Ass. Nessa fase, mesmo personagens cômicos como Fritz e Mr. Natural protagonizaram histórias sexualmente explícitas. Fritz the Cat Superstar, por exemplo, é completamente orientada em função de jogos sexuais e fantasias de dominação feminina.

A morte de Fritz (Figura 10), publicada em 1972 na revista The People's Comics, aponta para um fenômeno que se repetiria na trajetória de Crumb. Enquanto a maioria dos autores de histórias em quadrinhos se apegam às suas personagens, Crumb constantemente descartava suas criações. A única personagem recorrente em toda a carreira de Crumb é o próprio autor.

A tentativa de catalogar as histórias autobiográficas de Crumb é uma tarefa que se choca com alguns empecilhos, já que sua obra é bastante vasta e está dispersa em inúmeras publicações. Utilizamos como base os dezessete volumes da série The Complete Crumb (1987 - 2005), publicados pela Fantagraphics Books. Esta coleção é a mais exaustiva já publicada, catalogando as histórias em ordem cronológica e reunindo material inédito, como ilustrações, rascunhos e histórias amadoras. Mesmo assim, sabe-se que existem algumas lacunas, decorrentes principalmente do conflito entre direitos de publicação da Fantagraphics, Kitchen Sink Press e Last Gasp. Portanto, utilizamos também The R. Crumb Coffee Table Art Book (1987) e My 
Troubles with Women (2003). O livro R. Crumb, Checklist of Work and Criticism, de Donald M. Fiene (1981), também mostrou-se bastante útil para uma dupla checagem dos quadrinhos publicados até o início da década de 1980.
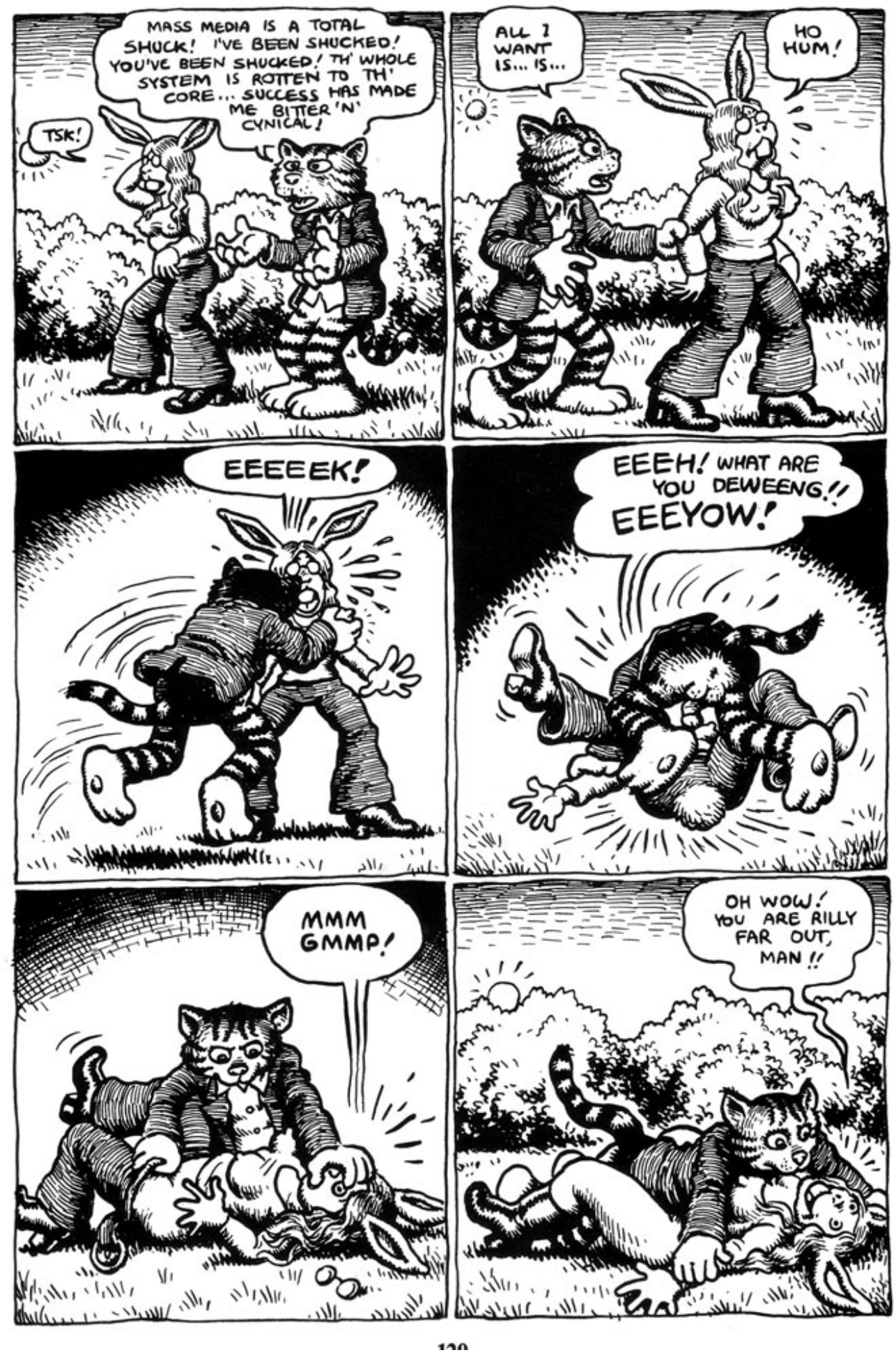

Figura 10 - Fritz the Cat, "Superstar" 


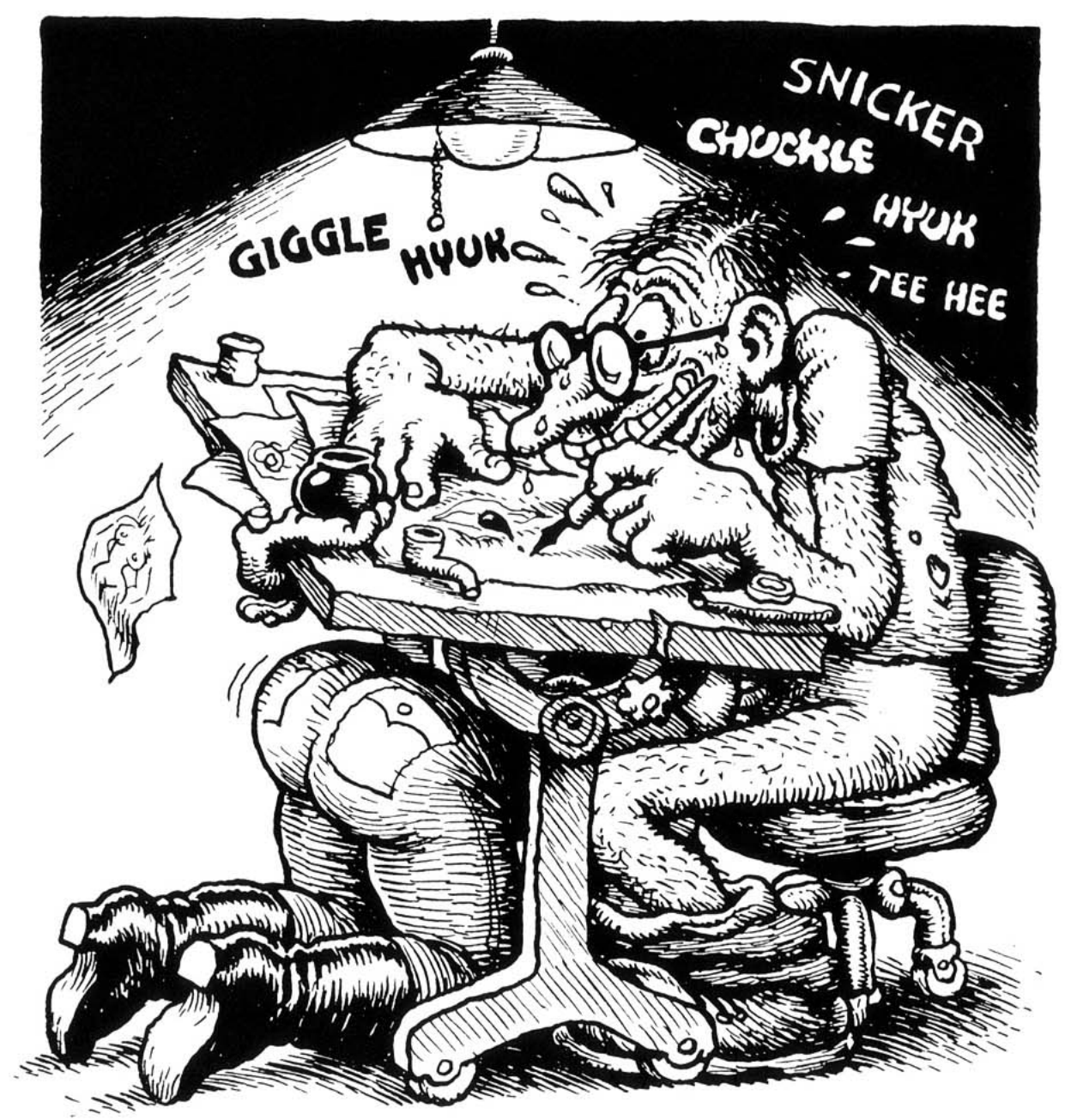

\section{THE PLEASURE IS OURS, FOLKS!} WE REALLY LIKE DRAWING DIRTY CARTOONS! IT HELPS US GET RID OF PENT-UP ANXIETIES AND REPRESSIONS AND ALL THAT KINDA STUFF... WE HDPE YOU ENJOY LOOKIN' AT 'EM AS MUCH AS WE ENJOY DRAWIN' EM !!

"WHAT THIS WORLD NEEDS IS MORE SATISFIED CUSTOMERS!"

Figura 11 - Anúncio da Snatch

Analisando a obra de Crumb, é possível identificar sinais de autorepresentacão pictográfica a partir de 1969, fragmentados nas diversas publicações criadas pelo autor ou que veiculavam seu trabalho. Em 1965, Crumb já havia se introduzido como uma personagem no diário de viagem em quadrinhos Bulgaria, mas esse trecho em específico foi cortado na versão final da revista Help $\mathrm{n}^{\circ}$ 25. Além disso, em 1967 ele criou Mr. Sketchum, um cartunista cuja aparência 
remetia ao próprio autor. Em um anúncio (Figura 11) de janeiro de 1969, publicado no segundo número da revista Snatch, é possível identificar um autorretrato onde a relação de identidade com o autor é estabelecida. Outro autorretrato aparece em abril do mesmo ano, na história Hi-lites of Detroit (Figura 12), publicada em Motor-City $\mathrm{n}^{\circ}$ 1. Nessas duas imagens já é possível identificar algumas características que se tornariam elementos pictográficos de identificação do autor, como os óculos de armação grossa e a expressão facial distorcida.

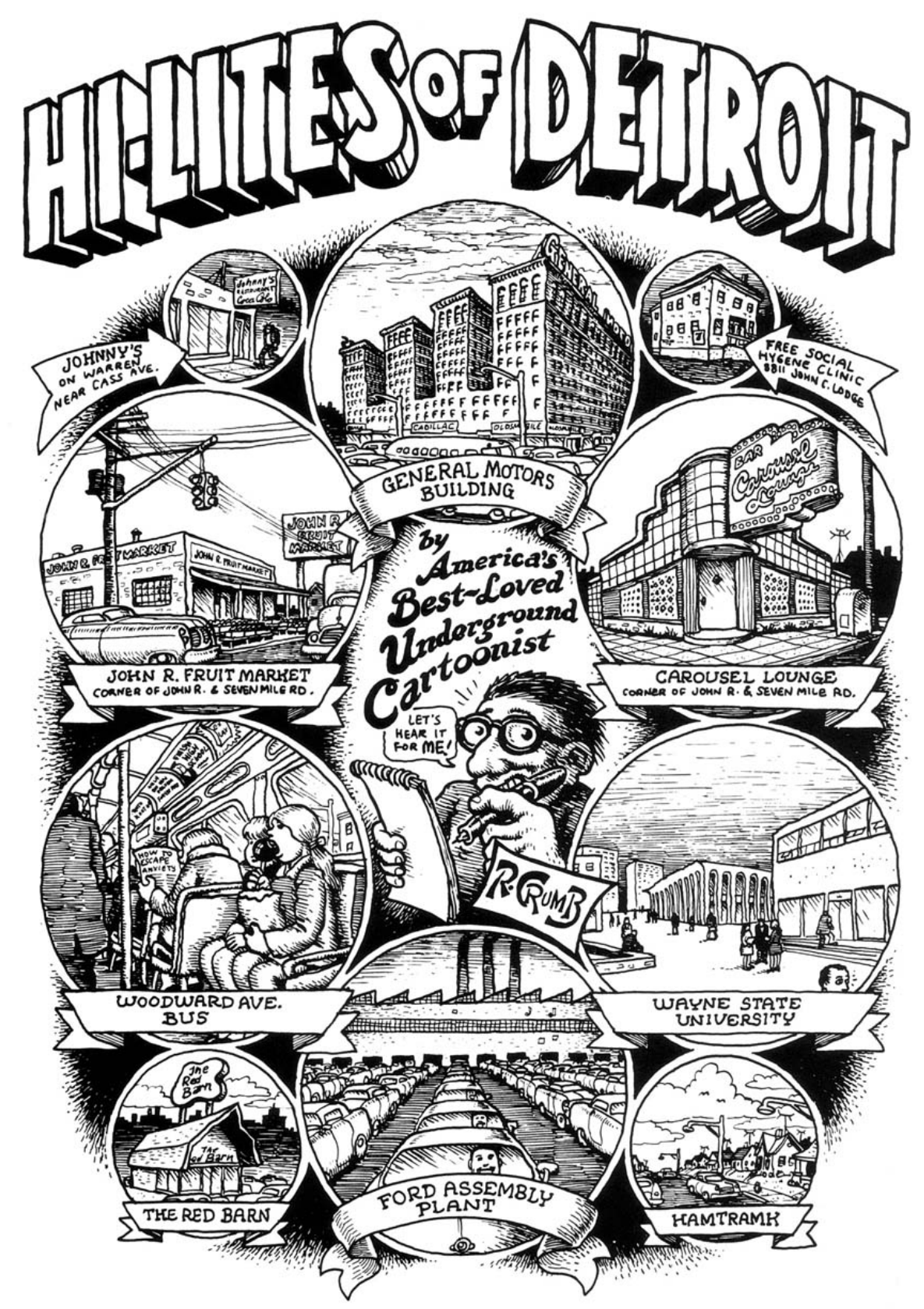

Figura 12 - Hi-Lites of Detroit 
Em 1970 Crumb amplia seu projeto de exploração da própria imagem com as primeiras experiências propriamente narrativas, inicialmente com a história de uma página Morbid Sense of Humor (Figura 13), publicado na revista Dispair, e depois com a história Underground Hotline, na San Francisco Comic Book no 3. As duas histórias possuem semelhanças interessantes: em Morbid Sense of Humor o autor fala diretamente com o público, tentando explicar sua obsessão pela violência; em Underground Hotline Crumb é entrevistado pela apresentadora Lark Clarck, que o questiona justamente acerca da natureza sádica e perversa de seus desenhos (sintomaticamente, Crumb termina a história estrangulando Lark). Ou seja, ambas as histórias funcionam como uma tentativa do autor de justificar a natureza extrema de algumas de suas produções.

Conforme destacamos anteriormente, depois do grande sucesso da revista Zap Comix, Robert Crumb passou a desfrutar de uma grande popularidade, sendo identificado como uma das figuras centrais da contracultura norte-americana. As histórias da fase inicial da produção de Crumb foram quase que unanimemente aceitas como representações vigorosas de uma sociedade em ebulição, mas a partir de 1968 a exploração contínua de suas obsessões sexuais atraiu críticas severas. De fato, as revistas Motor City e Big Ass apresentam sofisticadas fantasias de dominação feminina, onde sobejam a violência física e até mesmo relações não consensuais. A crítica principal a essas histórias é que Crumb teria abandonado a sátira inteligente em função da pura pornografia. A violência gráfica contra a mulher e as representações pouco lisonjeiras também atraíram a atenção de grupos feministas, destacando-se a polêmica entre Crumb e Trina Robbins, quadrinhista ligada a movimentos feministas radicais. “A women's liberation group in Wisconsin had gone into local retail outlets and put stickers on some of his comic books that said, 'This book exploits women" (ROSENKRANZ, 2002, p.208). No segundo volume da revista Big Ass, publicado em 1971, Crumb responde às críticas feministas em duas histórias: Underground Cartoonist and Folk Hero R. Crumb e And Now, a Word to you Feminist Women. Na primeira história vemos o paranoico autor em seu estúdio pouco antes de sofrer um atentado com gás venenoso perpetrado por um "agente do governo". Na segunda, Crumb se dirige às leitoras feministas, ressaltando seu direito à liberdade de expressão e a uma visão particular dos limites da criação artística.

Essas quatro primeiras histórias (Morbid Sense of Humor, Underground Hotline, Underground Cartoonist and Folk Hero R. Crumb e And Now, a Word to 
you Feminist Women), mais do que constituírem-se como modalidade autobiográfica, aproximam-se da simples metalinguagem. Crumb subverte as convenções narrativas dos quadrinhos, denunciando o caráter artificial dessa estrutura para falar diretamente com o leitor. Dito de outro modo, essas narrativas quadrinizadas assemelham-se mais a um comunicado que a uma experiência ou acontecimento da vida cotidiana. "Em Crumb já havia uma mistura de ficção e confissão quando o autor se introduz como personagem e se dirige expressamente ao leitor em primeira pessoa, revelando suas verdadeiras obsessões, em especial as sexuais" (GARCÍA, 2012, p.174).

As primeiras experiências autobiográficas propriamente narrativas perpetradas por Robert Crumb aparecem em 1972, na revista The People Comics: em The Confessions of R. Crumb é apresentada uma extravagante narrativa onde o autor regride ao útero, nasce e mantém relações sexuais com sua mãe; e no episódio The Robert Crumb $\$ u c k \$ e \$ \$$ o autor se representa como um magnata dos quadrinhos que subitamente vê-se trabalhando em campos de arroz, após uma revolução Maoísta nos EUA. Por essa breve descrição, é possível perceber que essas histórias não se baseavam em eventos vividos pelo autor. Mesmo assim, existe uma relação de identidade entre a personagem, o narrador e autor, o que poderia configurar um pacto autobiográfico. Esse jogo formal que subverte as categorias de identidade da autobiografia foi definido por Serge Dubrovski (2001) como autoficionalidade, uma espécie de "ficção de si mesmo". Assim, na autoficcionalidade existe uma correspondência entre a identidade do autor, da personagem e do narrador, ao mesmo tempo em que o pacto desfaz a correspondência entre os acontecimentos narrados e a realidade.

Boa parte da produção de Crumb se encaixa nessa modalidade de expressão, onde os impulsos de sua psique servem como força motriz para a criação de narrativas extravagantes sobre suas preferências sexuais não-ortodoxas e pretensões egômanas acerca de seu próprio talento. $\mathrm{O}$ autor parte de seus desejos para construir fantasias de encontros sexuais fortemente encenados, dominação do corpo feminino e exploração de práticas extremas. Essa narrativização de fantasias e ficcionalização de impulsos internos constituem um excelente exemplo do que ora chamamos de autoficção. Posteriormente, Crumb também inicia um projeto autobiográfico ao rememorar de maneira mais ou menos objetiva sua infância, relacionamentos amorosos, desenvolvimento da sexualidade na adolescência, etc, apenas alguns anos depois da Justin Green. 

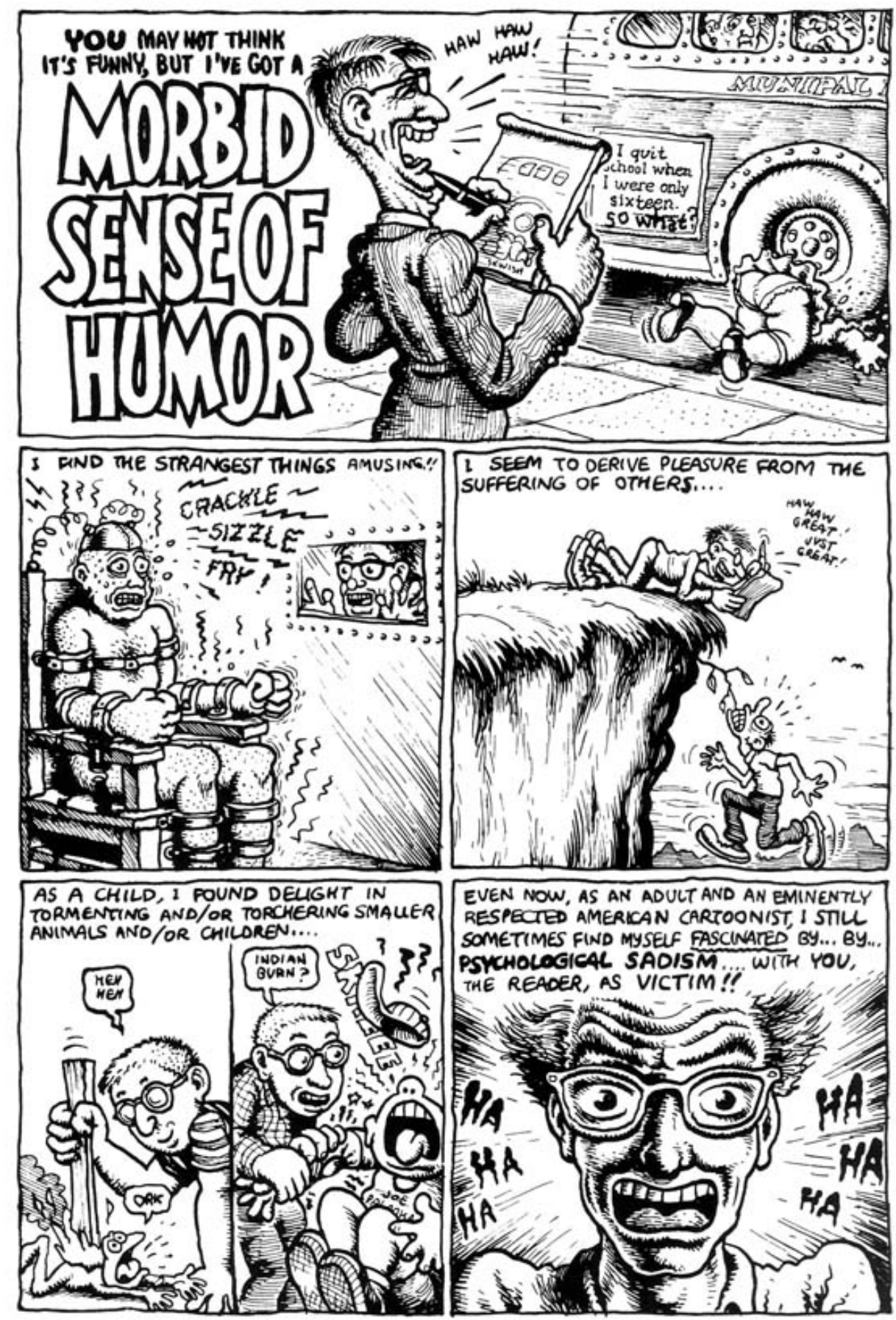

Figura 13 - Morbid Sense of Humor

Em 1972, Crumb publica na revista XYZ Comics a história The Many Faces of $R$. Crumb, onde já é possível observar um afastamento da autoficcionalidade. Nesse quadrinho de duas páginas, o autor constrói representações visuais cômicas de diversas facetas de sua personalidade (caipira, homem de negócios, pervertido, etc) que, em determinado sentido, já funcionam como uma experiência de sondagem da vida interior. Após a publicação de Binky Brown, Crumb produz sua primeira 
narrativa propriamente autobiográfica: My First LSD Trip, publicada em 1973 na revista El Perfecto Comics. Nessa história, Crumb narra de forma verossímil sua primeira experiência com LSD, destacando logo acima do título a veracidade dos fatos narrados (Figura 14). Essa narrativa se afasta da autoficcionalidade por abordar percepções reais e relatar acontecimentos cuja veracidade pode ser comprovada. Em certo sentido, a própria verossimilhança da narrativa pode funcionar como um índice para determinar se uma narrativa é autobiográfica ou autoficcional. É certo que o absurdo e o inesperado acontecem o tempo todo na experiência cotidiana, mas existem determinadas categorias de eventos que ultrapassam qualquer possibilidade física, como a regressão ao útero presente na história The confessions of $R$. Crumb, que citamos anteriormente.

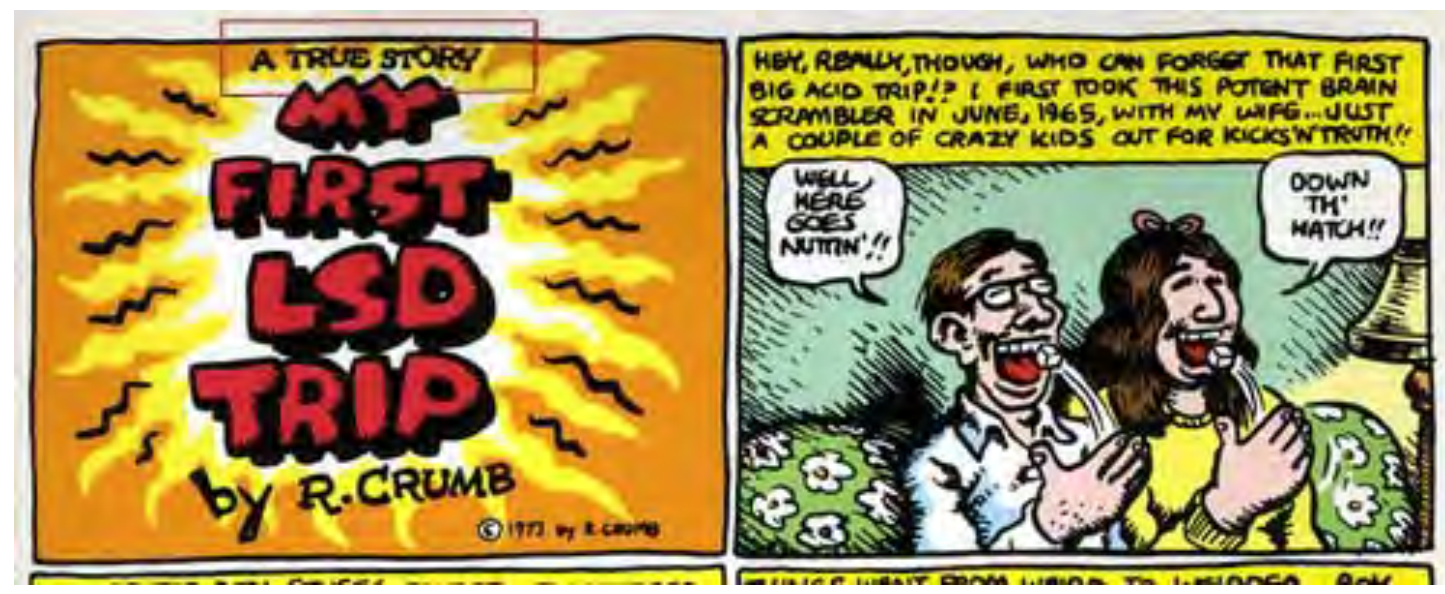

Figura 14 - My First LSD Trip

Nas histórias seguintes existe uma oscilação entre narrativas autoficcionais e autobiográficas. Embora não exista um padrão rígido, é possível identificar que até a desarticulação do movimento comix, no final da década de 1970, existe uma predominância de narrativas autoficcionais. Nas histórias The Adventures of $R$. Crumb Himself (Tales From the Leather Nun, 1973), R. Crumb Versus The Sisterhood (Black and White Comics, 1973), R. Crumb Present R. Crumb (Zap Comix $n^{\circ} 7$, 1974), Modern Dance Workshop (CoEvolution Quartely n 14, 1977) e High Times Interview R. Crumb (High Times $n^{\circ} 27$, 1977) é possível encontrar ficcionalizações de experiências, fantasias masturbatórias e aventuras extravagantes que beiram o surreal. Em The Adventures of R. Crumb Himself, por exemplo, a personagem Crumb sofre uma tentativa de castração, passa boa parte das vinhetas correndo nu pelas ruas, decepa a cabeça de uma freira e explode uma escola. $R$. 
Crumb Versus The Sisterhood também apresenta uma narrativa bastante inverossímil, já que uma contenda física com uma feminista radical (obviamente, uma mulher grande e forte) desanda para uma bizarra trama de dominação sexual.

Após essa série de histórias autoficcionais, Crumb produz uma espécie de reportagem em quadrinhos a convite da revista CoEvolution Quarterly. Na história Space Day Symposium, de 1977, o autor é enviado para fazer a cobertura de um encontro sobre pesquisas aeroespaciais. O relato é bem pouco informativo e se detém mais nas impressões subjetivas. No ano seguinte a CoEvolution Quarterly publica Theasure Days Island, uma reminiscência da infância do autor. Após um hiato de três anos, Crumb revisita a temática autobiográfica com as histórias My Troubles with Women (Zap Comix $n^{\circ} 10,1980$ ), I Remember the Sixties (High Times $n^{\circ}$ 94, junho de 1983) e My Troubles with Woman part II, Hup nº1, 1986). Essas três histórias têm uma estrutura que percorre memórias temáticas (exemplificadas no título), onde o autor, ancorado no presente, rememora acontecimentos do passado. Em Uncle Bob's Mid-Life Crisis (Weirdo $\mathrm{n}^{\circ}$ 08, 1983) temos uma rara história ambientada no "presente", acompanhando um dia comum de sua vida familiar. Em 1987 é publicada a história Footsy (Weirdo $\mathrm{n}^{\mathrm{o}} 20$ ), que acompanha de forma linear o jovem Crumb e seu fetiche por pés.

Dando provas que a oscilação entre narrativas autobiográficas e autoficcionais não segue nenhum padrão específico, a próxima história de Crumb é um incrementada fantasia sexual chamada If I Were a King (HUP $\mathrm{n}^{\circ 2}$, 1987). Em seguida, duas histórias autobiográficas: Memories are Made of This (Weirdo ${ }^{\circ} 22$, 1988) e I'm Grateful! I'm Grateful! ( Weirdo no 25, 1989). Na Weird n ${ }^{\circ} 26$, Crumb constrói uma claustrofóbica experiência de autoficção. Na história People... Ya Gotta Love'em!, o autor atravessa uma multidão de pessoas nuas até chegar a um mar poluído de aparência pós-apocalíptica.

Concluindo a catalogação das histórias, temos uma outra reportagem intitulada R. Crumb, 'The Old Outsider', Goes To The Academy Awards (Premiere Magazine vol 4, no 8, 1991) e a peculiar Ode to Harvey Kutz (Harvey Kutzman's Strange Adventures, 1990). Além disso, Crumb constantemente utiliza sua própria imagem em ilustrações editoriais e artes comissionadas; além de se inserir como personagem incidental em algumas narrativas, como em Modern America (Arcade n², 1975) e Where Has It Gone, All The Beautiful Music Of Our Grand Parents? (Weirdo no 14, 1985). 


\subsection{Pictografia e realidade visual}

Uma das questões centrais que se impõem quando abordamos os quadrinhos em um âmbito formal diz respeito a sua configuração pictográfica. Esse caráter proeminente da informação gráfica se relaciona com a própria natureza da linguagem dos quadrinhos, que pode comportar narrativas "mudas" (sem texto nos balões e recordatórios), mas nunca histórias sem informações visuais. Mesmo em histórias onde o aspecto textual é proeminente, a informação pictográfica ainda desempenha um importante papel para a construção da narrativa. Conforme Will Eisner

As histórias em quadrinhos são, essencialmente, um meio visual composto de imagens. Apesar das palavras serem um componente vital, a maior dependência para descrição e narração está em imagens entendidas universalmente, moldadas com a intenção de imitar ou exagerar a realidade (EISNER, 2008, p.5).

Qualquer tentativa de definir os quadrinhos necessariamente perpassa pelo conceito da "narrativa por imagens". Scott McCloud, por exemplo, define essa forma de linguagem como "imagens pictóricas e outras justapostas em sequência deliberada destinadas a transmitir informações e/ou produzir uma resposta no espectador" (2005, p.09). Embora essa definição apresente alguns problemas, principalmente no que se refere à amplitude desse conceito (GARCÍA, 2012, p.41), ela também reforça a centralidade da informação gráfica.

Além da condução da narrativa, as imagens também desempenham outras funções nos quadrinhos, normalmente relacionadas à experiência estética. No caso específico das narrativas autobiográficas, a configuração pictográfica choca-se ainda com a necessidade de construir modelos eficientes de representação da realidade visual, já que deve dar conta de eventos que ocorreram em lugares e contextos específicos. Portanto, mesmo que o artista se expresse em seu estilo característico, deve reproduzir a aparência exterior das pessoas, objetos e lugares de modo a criar uma relação de referencialidade entre a pictografia e o real. Esse estilo não precisa ser necessariamente realista; distorções e exageros nas representações gráficas podem inclusive contribuir para transmitir estados mentais e percepções alteradas, mas uma história em quadrinhos de não-ficção que rejeite completamente um grau mínimo de 
equivalência com a realidade visual (um quadrinho abstrato, por exemplo) enfraquece o vínculo que, justamente, propõe-se a criar. A capacidade da pictografia em representar de forma eficiente a realidade visual é, portanto, um dos primeiros problemas que se impõem para a análise da autobiografia em quadrinhos.

Quando consideramos o vínculo de referencialidade visual que os quadrinhos autobiográficos desenvolvem com sua contraparte concreta, é possível perceber o quanto esse processo se insere na contramão do desenvolvimento midiático, já que desde o século XIX é instaurado um regime de registro e reprodução da realidade visual baseado em dispositivos tecnológicos. A fotografia é primeiro procedimento técnico a se impor como uma espécie de "registro visual da verdade" (SOUZA, 2000, p.09). Logo em seguida, o cinema introduz a perspectiva do movimento. Segundo Bill Nichols

Uma forma corrente de explicar a ascensão do documentário inclui a história do amor do cinema pela superfície das coisas, sua capacidade incomum de captar a vida como ela é; a capacidade que serviu de marca para o cinema primitivo e seu imenso catálogo de pessoas, lugares e coisas recolhidas em todos os lugares do mundo. Como a fotografia antes dele, o cinema foi uma revelação. As pessoas nunca tinham visto imagens tão fiéis a seus temas num testemunhado movimento aparente que transmitisse sensação tão convincente de movimento real (NICHOLS, 2005, p.117).

Em oposição a essas tecnologias de registro baseadas na fidelidade da imagem, a configuração pictográfica encontrada nos quadrinhos autobiográficos de Robert Crumb e outros autores ligados ao movimento comix afastam-se completamente de um estilo que poderia ser considerado ilusionista ou fotorealista. Mesmo assim, nessas obras são construídos modelos dialógicos que funcionam como índices de reconhecimento para uma experiência visual mais completa e realista. Isto ocorre principalmente devido ao processamento integrado de estímulos visuais efetuado pelo cérebro. E. H. Gombrich argumenta que o receptor desempenha um lugar central na fruição das obras de artes em geral. Em sua abordagem da psicologia do receptor, que alia um estudo das formas de representação com os princípios do funcionamento de recepção da obra artística, Gombrich admite que a questão 
psicológica inerente ao processo da percepção visual é muito complexa para ser explicada de maneira satisfatória, mas que do receptor na leitura de uma imagem é fácil de ser demonstrado (2007, p.07). Gombrich utiliza a imagem reproduzida abaixo (figura 15) para exemplificar o papel ativo desempenhado pel receptor que, nesse caso específico, determina a leitura da imagem: um pato ou um coelho. Neste caso, o observador é responsável por adequar uma representação incompleta e confusa (uma série de linhas confusas e sem padrão) a um modelo de representação previamente conhecido.

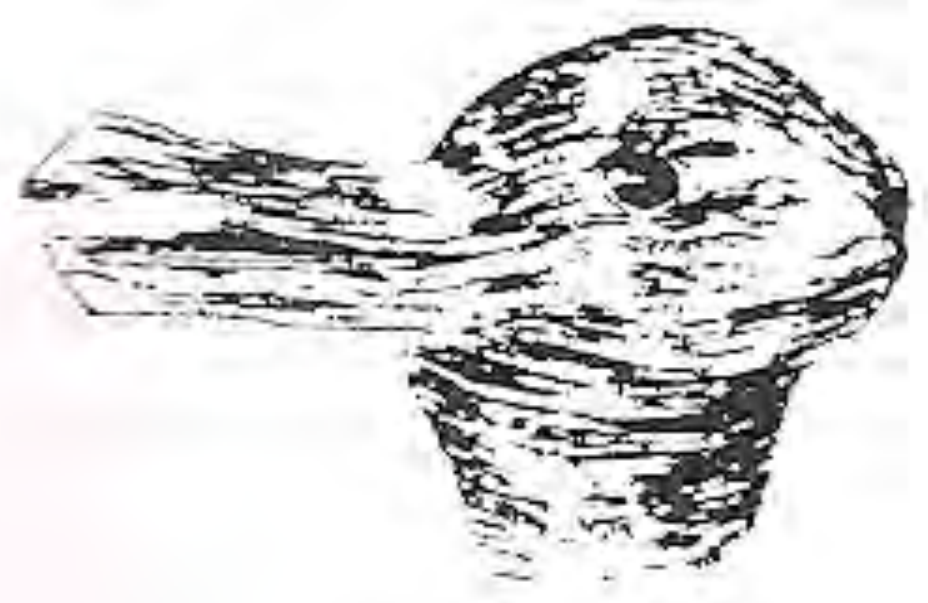

Figura 15 - O pato-coelho

Outra abordagem dos estudos acerca da percepção visual foi desenvolvida por Rudolf Arnheim e baseia-se no funcionamento fisiológico da visão e nos fundamentos da psicologia da gestalt. Arnheim define como lei básica da percepção visual que "qualquer padrão de estímulo tende a ser visto de tal modo que a estrutura restante é tão simples quanto as condições dadas permitem" (2000, p.47). Segundo Arnheim, o cérebro sempre trabalha em função de um "conhecimento adquirido" para efetuar a leitura das imagens em função de um padrão mais simples e lógico. Dessa forma, se o observador vê a cabeça de um homem por trás de um muro não imagina que ela está flutuando, pelo contrário, o mapa mental traçado em situações semelhantes aponta para a leitura correta dessa cena.

Tanto a psicologia do receptor, quanto a análise da percepção visual inspirada pela gestalt, preocupam-se em estabelecer as relações entre os estímulos visuais difusos e forma como o cérebro constrói a ilusão da realidade visual. O princípio 
fundamental seria a aferição do processo da visão. Segundo Arnheim, “A descrição do processo ótico, conforme os físicos, é bem conhecida. A luz é emitida ou refletida pelos objetos do ambiente. As lentes dos olhos projetam as imagens destes objetos nas retinas que transmitem a mensagem ao cérebro" (2000, p.35). A luz possibilita a percepção da borda visual, pela diferença de iluminação entre duas superfícies, e os bastonetes da retina possibilitam que se perceba as cores. A percepção da imagem artística acontece por esse mesmo processo. Dessa forma, as imagens simplificadas e incompletas das histórias em quadrinhos autobiográficas são "lidas" pelo cérebro como modelos análogos à realidade visível. Obviamente, o aspecto estético e a própria concretude da matéria desenhada faz-se presente, mas de modo geral é estabelecido um vínculo com a realidade visível.

No que se refere à característica de incompletude da imagem pictográfica, os quadrinhos autobiográficos desenvolvidos no contexto dos comix destacam-se pela limitação de expedientes gráficos. Como esclarecemos anteriormente, o barateamento da impressão possibilitado pelo offset permitiu o surgimento da imprensa alternativa nos Estados Unidos. O offset é uma técnica de impressão indireta capaz de efetuar reproduções de alta qualidade gráfica, em até 6 cores e com retículas regulares ou variáveis. Contudo, no contexto específico dos comix, a impressão a cores não era financeiramente viável e a maior parte dos operadores de máquinas e prensas eram aventureiros ligados à contracultura que só dominavam os rudimentos das técnicas de impressão. Na Rip Off Press, uma das principais editoras underground a imprimir o material dos autores ligado ao movimento comix, existia um sério problema para dosar a quantidade de tinta nos rolos de impressão, inutilizando grandes quantidades de material (ROSENKRANZ, 2002, p.132). Nas outras editoras alternativas, como Print Mint e Apex Novelties, a situação não era muito diferente. Considerando esses entraves técnicos, a autobiografia em quadrinhos desenvolvida nesse contexto caracterizava-se pela ausência de cor e pela pictografia centrada em linhas fortes e bem definidas. Essa configuração mais simples facilitava a reprodução e diminuía o risco de produzir um material inutilizável.

Essa utilização da linha como base estrutural da imagem pictográfica remete ao modelo natural da percepção humana, tendo em vista que a linha é uma forma gráfica que remete à borda visual. "Delimita-se a forma física de um objeto por suas bordas - o contorno retangular de um pedaço de papel, as duas superfícies que delimitam os lados e a base de um cone" (ARNHEIM, 2000, p.39). Assim, a linha é 
encarada como um modo natural de percepção, de maneira que um simples padrão de contorno permite que se identifique com facilidade o objeto retratado. Conforme Donis A. Dondis

$\mathrm{Na}$ arte [...] a linha é o elemento essencial do desenho, um sistema de notação que, simbolicamente, não representa outra coisa, mas captura a informação visual e a reduz a um estado em que toda a informação visual supérflua é eliminada, e apenas o essencial permanece (DONDIS, 2007, p.56).

No caso específico dos quadrinhos, além da borda visual, a capacidade de identificar facilmente um rosto, por mais que este se apresente num padrão simplificado também contribui para a percepção visual que simula a experiência "natural". Segundo Arnheim, "umas simples linhas e pontos são de imediato reconhecidos como um rosto, não apenas pelos civilizados ocidentais, que podem ser suspeitos de estarem de acordo com o propósito dessa 'linguagem de signos', mas também por bebês, selvagens e animais" (ARNHEIM, 2000, p.36). O experimento da cartunização, que consiste em simplificar e deformar a aparência de determinados objetos e pessoas até um ponto em que ainda são reconhecíveis, baseia-se nessa capacidade humana de relacionar pontos simplificados com a aparência de objeto em si (GOMBRICH, 2007, p.296). Outros fatores perceptivos, como a constante de forma e tamanho, a tendência para uma configuração mais simples e à percepção total do objeto, também contribuem para que se possa identificar naturalmente uma ilustração simples como uma representação da realidade visível. Desse modo, embora os quadrinhos normalmente não se preocupem em representar a realidade visual de forma eficiente (análoga à fotografia), sua configuração pictográfica pode funcionar como índice de reconhecimento de uma experiência real, uma vez que se estabeleça o pacto autobiográfico de leitura.

Um caso emblemático desse processo de construção de modelos dialógicos que não se ancora em um estilo realista, pode ser encontrado na obra do quadrinhista canadense Guy Delisle (Figura 16). As histórias em quadrinhos de Delisle definem seu caráter não-ficcional a partir da própria constituição da narrativa, que relatam viagens para a Coréia do Norte, China, Birmânia e Jerusalém. O pacto autobiográfico também é estabelecido a partir da relação de identidade entre autor, personagem e 
narrador. Esses elementos orientam um tipo de leitura onde o papel do receptor é complementar essa representação pictográfica simplificada e estabelecer relações dialógicas com a percepção "natural". Além disso, o estilo de Delisle, apesar de extremamente simples e esquemático, segue determinadas convenções que permitem uma inferência mínima com a realidade visual (o que não aconteceria em um quadrinho de inspiração cubista, por exemplo).

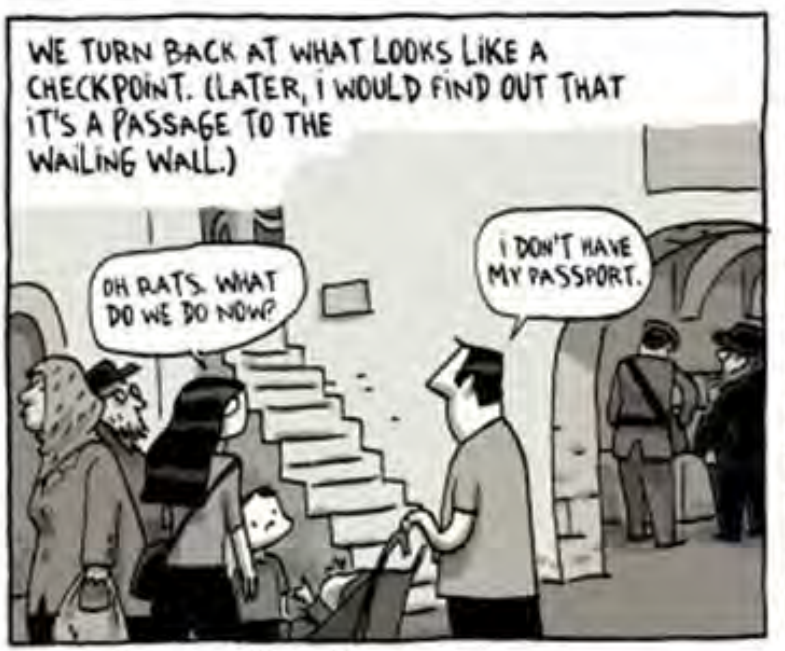

TO THE LEFT, POLICE AND SOLDIERS ARE FILLING OUT A REPORT. PEOPLE CLAMOUR ARCUND WITH THEIR VERSION OF EVENTS.

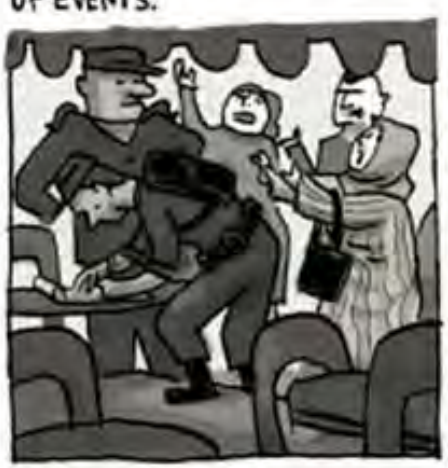

IN THE MEANTIME, A LINE OF TOURISTS CLEARS A PATH THROUGH THE TABLES TO REACH AN ATM.

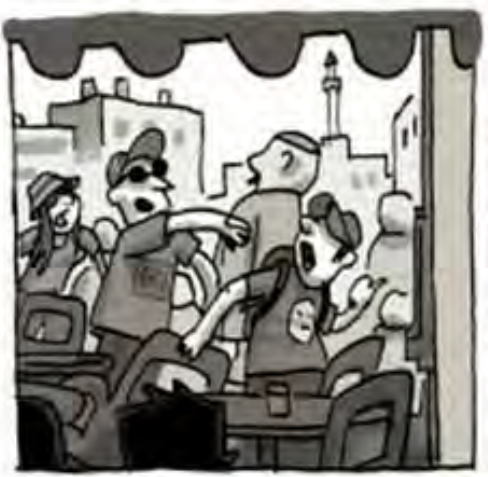

WE STOP FOR A MINT LEMONADE. THE FEEL OF THE PLACE IS SOMETHING ELSE.

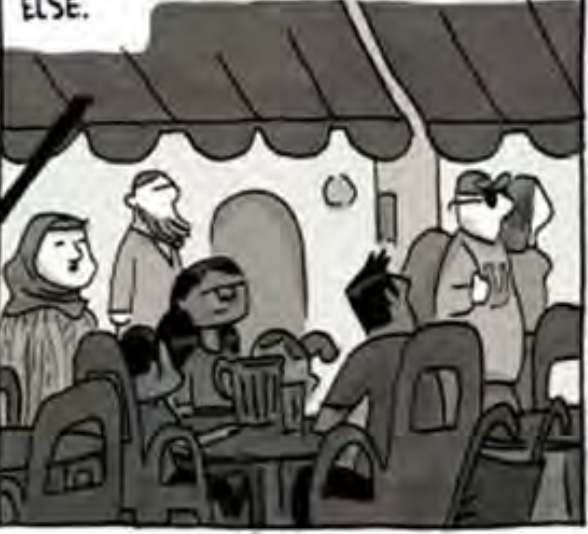

AND OPPOSITE, A GROUP OF ITALIANS STOP TO PRAY IN FRONT OF A SMALL CHAPEL.

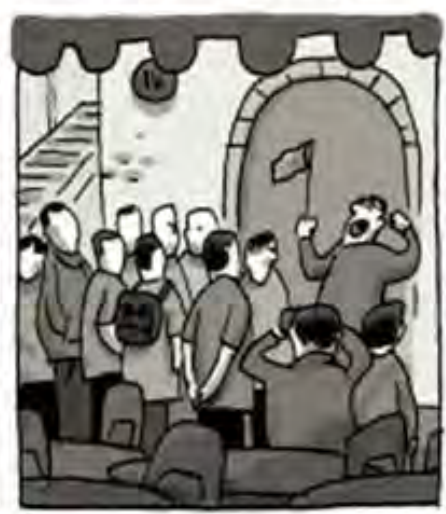

Figura 16 - Crônicas de Jerusalém

Os quadrinhos de Delisle são um caso limite no que se refere a construção de modelos dialógicos com a realidade visual. A maior parte dos artistas que produzem quadrinhos de não-ficção ou têm um estilo mais realista, ou utilizam construções gráficas que agregam mais informações visuais. No caso específico de Robert Crumb é possível identificar os dois fenômenos. Em primeiro lugar, o estilo do autor encontra-se num ponto intermediário entre o que se pode considerar como realista 
(neste caso, remetendo à ilustração acadêmica e não à fotografia) e o cartum propriamente dito. Essa proximidade entre a representação pictográfica e aparência da realidade visual consegue fortalecer o caráter não-ficcional das narrativas autobiográficas que, neste caso, necessitam de menos elementos exteriores à obra para estabelecer o pacto autobiográfico. Além disso, identificamos uma oscilação no que se refere ao grau de realismo nas obras de Crumb, que tende a construir representações menos cartunizadas nas obras autobiográficas.
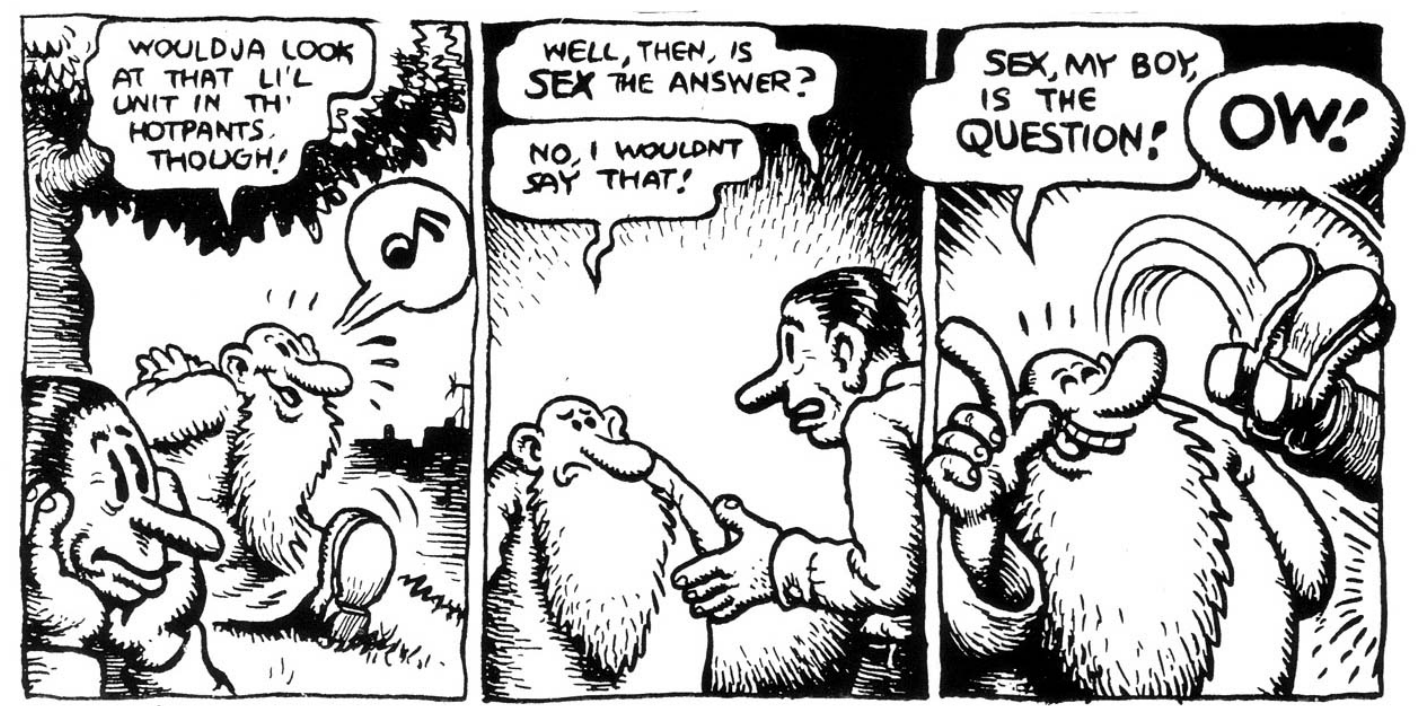

Figura 17 - Mr. Natural e Flakey Foont in "A Gurl in Hotpants" (1971)

De forma geral, é possível afirmar que o estilo de Crumb tende a ficar mais realista conforme se avança para as produções mais recentes, mas se nos detivermos em um momento específico qualquer é possível ainda identificar um realismo maior nas histórias autobiográficas. Para fins de comparação, escolhemos duas histórias produzidas no início da década de 1970, que se assemelham por abordarem situações do cotidiano e pela presença de personagens humanas (a comparação ficaria prejudicada no caso dos funny animals, como Fritz The Cat). A primeira, Mr. Natural e Flakey Foot in "A Gurl in Hotpants", de 1971, é protagonizada pelo Mr. Natural, uma das personagens mais populares e recorrentes da carreira do autor; e a segunda a já citada The Adventures of Robert Crumb Himself, de 1973. As duas histórias apresentam configurações gráficas semelhantes, com linhas uniformes e muitas hachuras, mas apresentam diferenças significativas na forma como são representadas as figuras humanas. Mr. Natural (Figura 17), por exemplo, é representado numa 
configuração extremamente simples e cartunizada, com o corpo desproporcional, nariz proeminente, olhos puntiformes e pés gigantescos, que remetem à estética dos quadrinhos das década de 1920 e 1930, como Mutt and Jeff e Popeye (DANNER; MAZUR, 2014, p.24). Já os autorretratos de Crumb (Figura 18) afastam-se das convenções do cartum, reproduzindo de forma menos estilizada a aparência física do autor. Na ilustração reproduzida abaixo é possível perceber uma semelhança concreta com o autor, bem como um detalhamento em sua fisionomia (rugas, sobrancelha, formato do nariz). O próprio ambiente é bastante detalhado, reproduzindo não apenas $\mathrm{o}$ interior da casa como a rua vista pela janela. De modo geral, essa vinheta transmite uma impressão muito palpável de "concretude", como algo que simula uma determinada percepção visual. Tudo isso, obviamente, ressignificado pelo estilo e visão particular do artista.

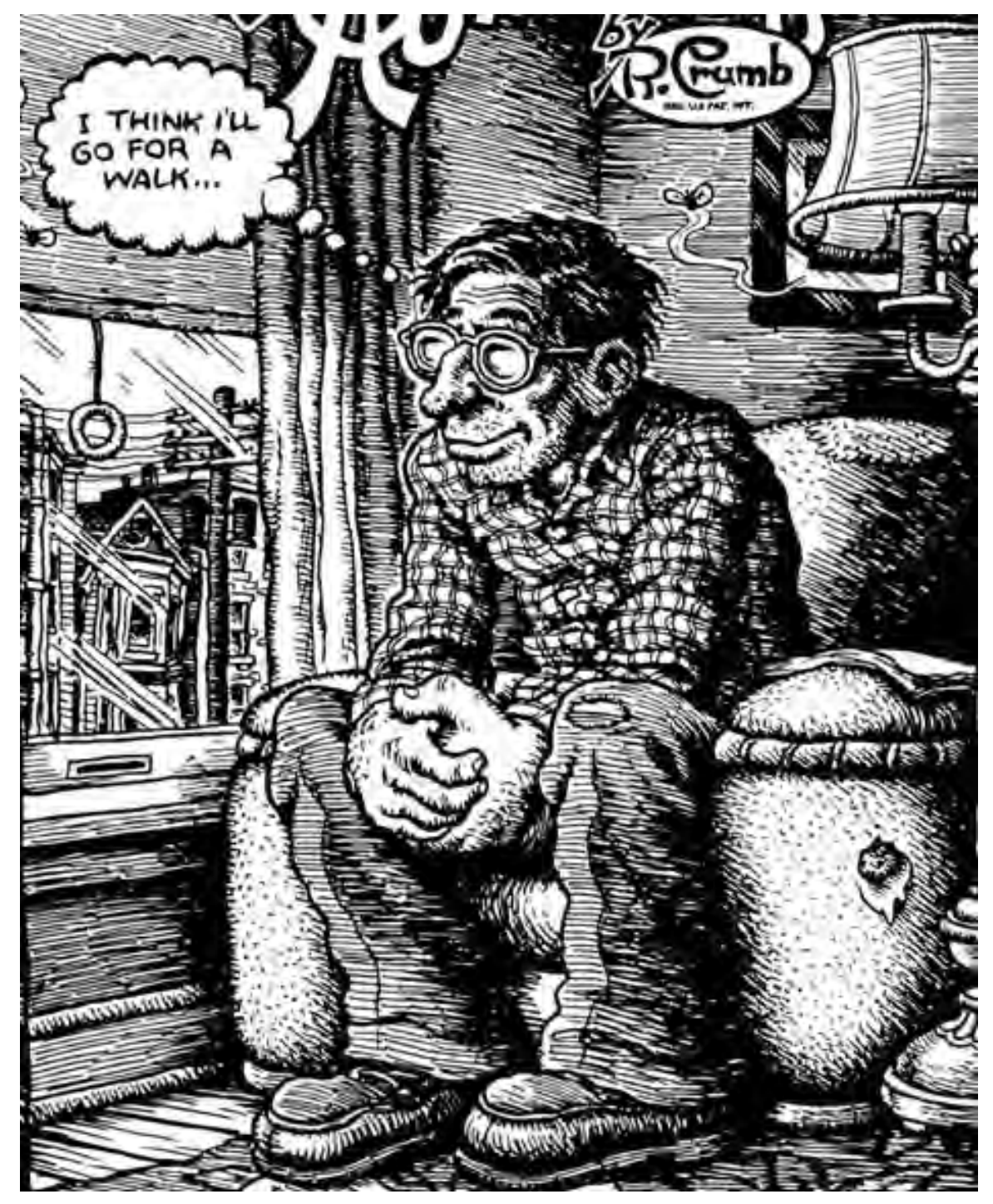

Figura 18 - The adventures of Robert Crumb Himself (1973) 
Um outro aspecto que se destaca no estilo de Crumb é a clareza de sua pictografia. No início da carreira, Crumb utilizava como ferramenta de desenho principalmente canetas técnicas, a mesma utilizada por arquitetos e outros profissionais. Esse tipo de caneta produz um traço bastante uniforme, sem variação na espessura das linhas. Na história Fritz The Cat (Figura 19), de 1965, é possível perceber como o autor utiliza de forma criativa as hachuras para criar volume nas personagens, fazer o sombreamento e transmitir uma sensação de profundidade no cenário. Esse senso de design eficiente e a utilização das hachuras facilitam a leitura da imagem, de forma que o leitor consegue perceber de forma imediata e sem dificuldades toda a ação que se desenrola nos quadros.
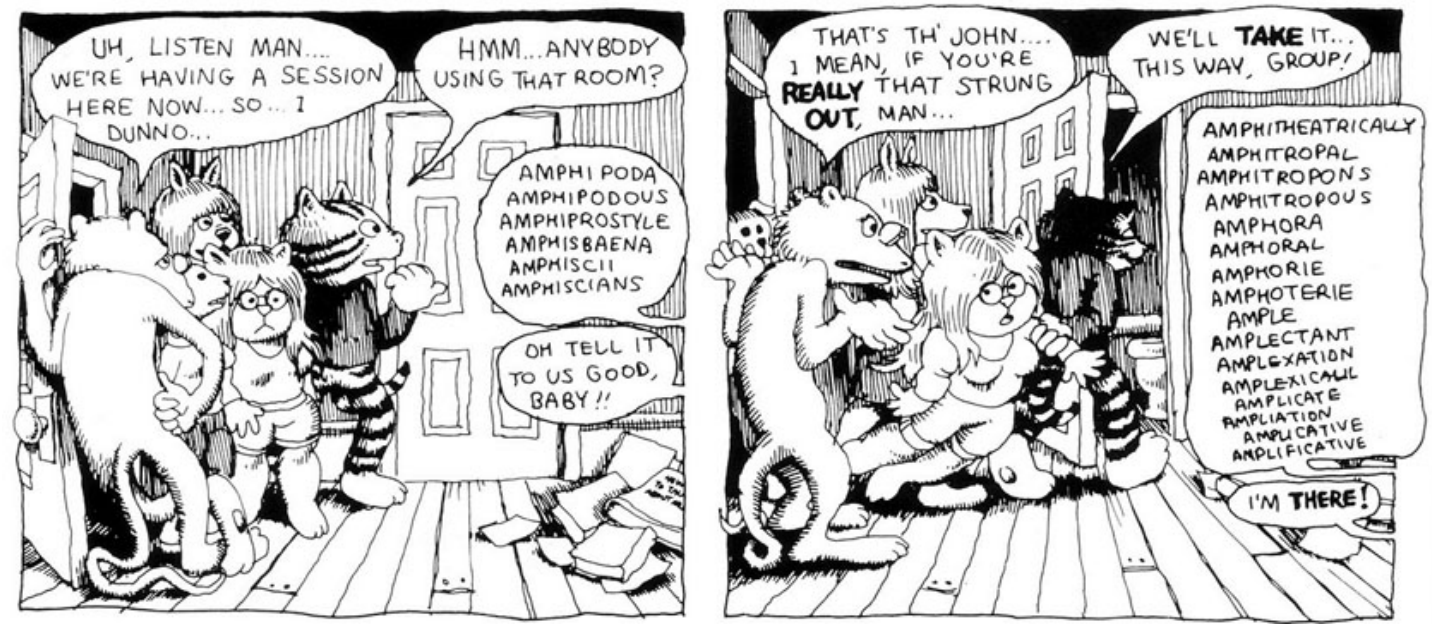

Figura 19 - Fritz the Cat

Alguns anos depois, Crumb começa a utilizar outros materiais de desenho, como a pena (caneta tinteiro) e o pincel. Ambos os materiais proporcionam uma maior maleabilidade, com traços irregulares e de dimensões variáveis. Seu estilo pictográfico torna-se ainda mais claro, já que o autor utiliza linhas mais grossas para delimitar as personagens e diferenciar o primeiro e o segundo plano. Em Dirty Dog (Figura 20), publicada na ZAP n³ em 1968, já é possível perceber como a variação na espessura das linhas facilita a leitura da imagem. O contorno das personagens que caminham na calçada é nitidamente mais grosso que o dos carros ou dos prédios em segundo plano. As hachuras também são mais pesadas nessas personagens que no resto do cenário, um procedimento simples que consegue adicionar volume e transmitir um senso de profundidade na ilustração. Novamente, não há dificuldades em compreender a cena, nem de identificar os objetos que são representados (carros, 
postes, prédios, etc). Em geral, os quadrinhos de Crumb constroem um tipo de representação que se assemelha bastante com a experiência visual da realidade, criando um vínculo que se fortalece quando se institui o pacto autobiográfico.

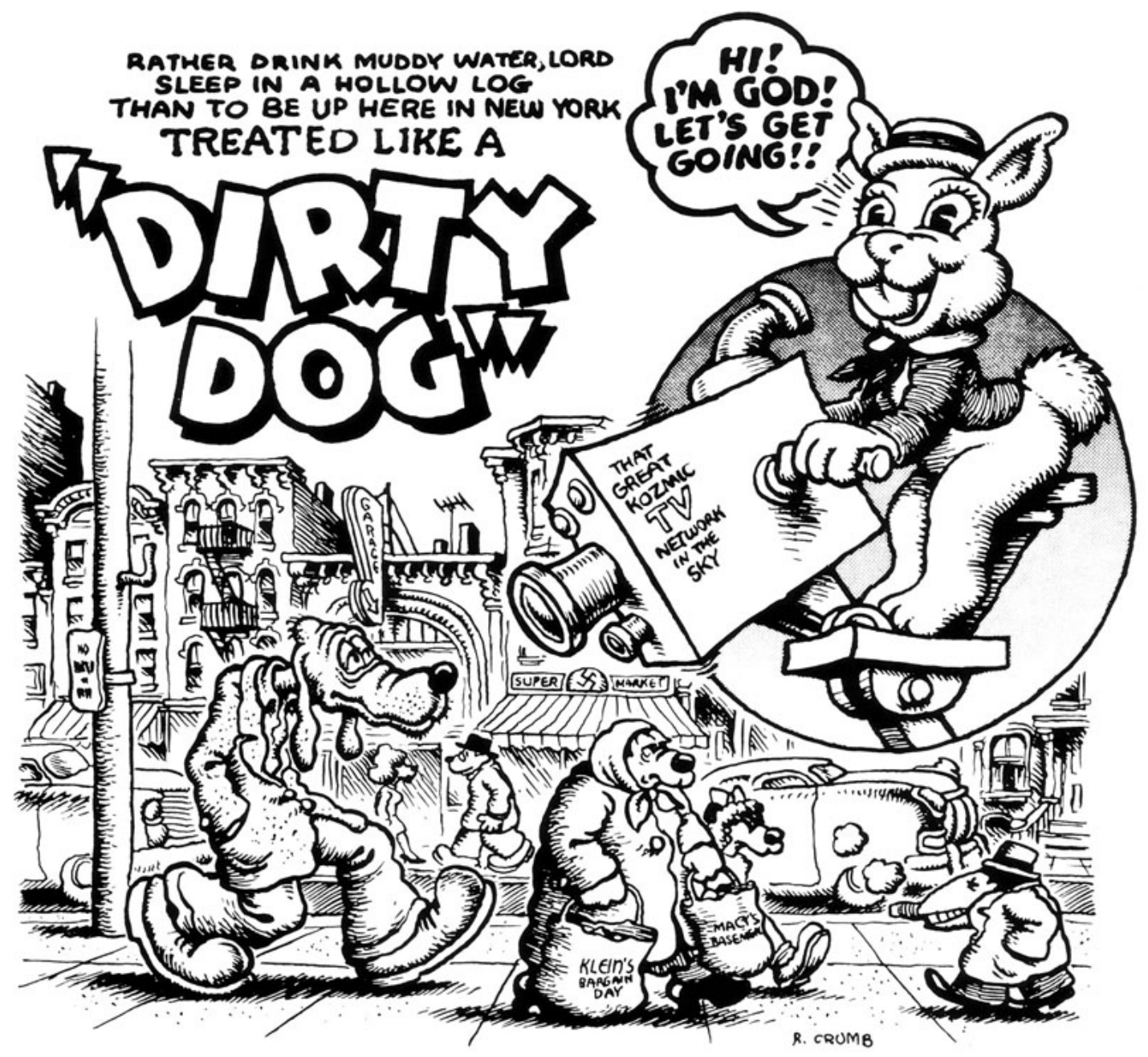

Figura 20 - Dirty Dog

Pode parecer muito óbvio que as necessidades narrativas impulsionem os quadrinhos em função de uma busca por construir representações que se aproximem da realidade, mas em alguns casos acontece justamente o oposto. Muitos criadores utilizam um grafismo que rompe completamente com qualquer noção préestabelecida pela experiência comum. Os exemplos seriam muito numerosos mas, para fins de comparação, reproduzimos a segui uma história em quadrinhos de Rick Griffin, também publicada na Zap Comix n 3 . 


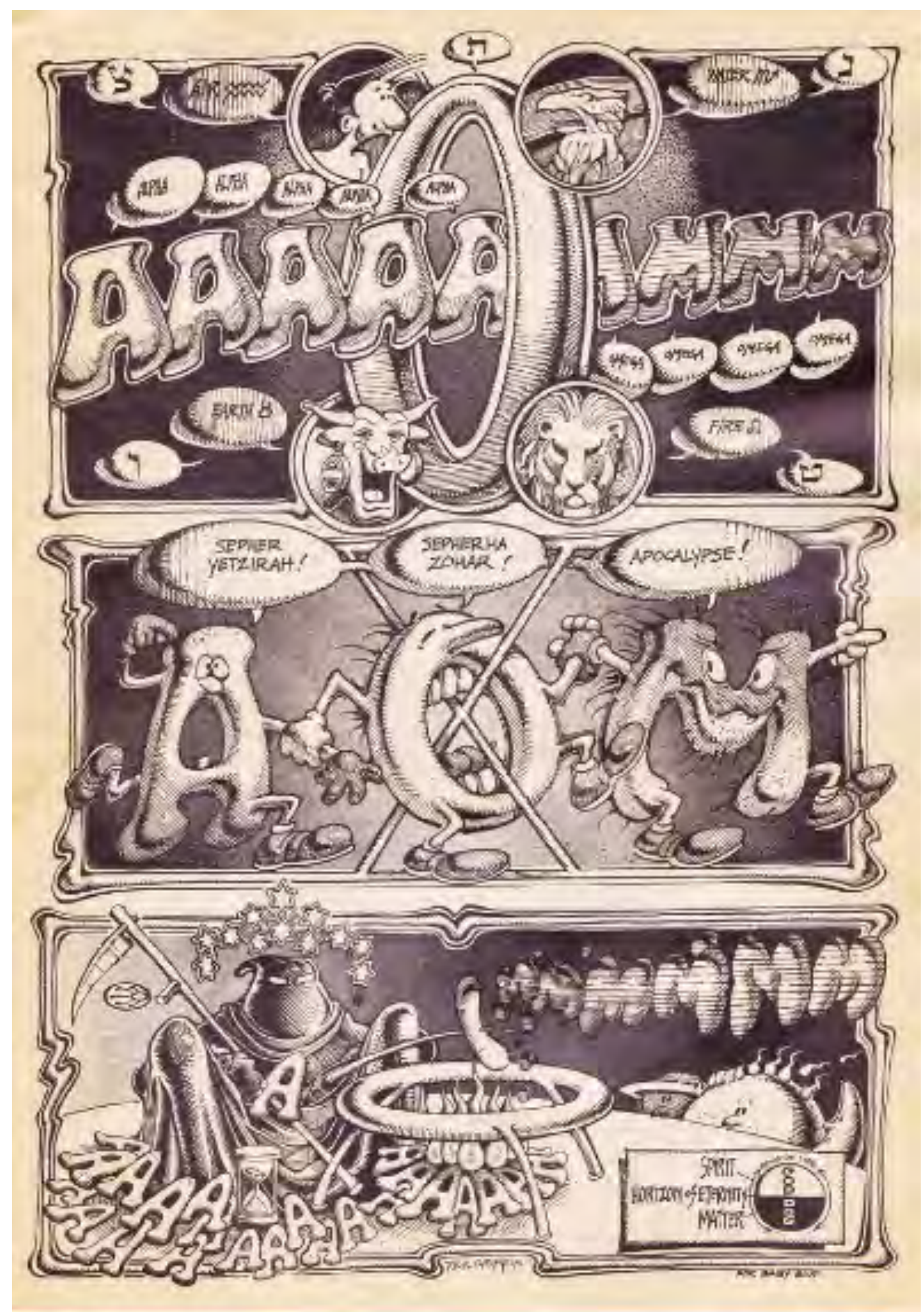

Figura 21 - “AOM”, de Rick Griffin

Embora não tenha um título facilmente reconhecível, esse quadrinho de apenas uma página é normalmente designado como "AOM”. Nele é possível perceber diversos elementos que se afastam do modelo de representação utilizado por Crumb: a divisão de quadros é confusa e as vinhetas são ornadas por arabescos; os elementos 
conceituais, como onomatopeias e balões, são utilizados de forma criativa e metalinguística; o entendimento das ações representadas é difícil; e, no geral, toda a construção gráfica se afasta de qualquer padrão apreendido na experiência comum. Quando comparada a Rick Griffin ou outros quadrinhistas underground cuja obra é mais experimental, como Robert Willians ou Victor Moscoso, percebe-se que o trabalho de Crumb não apenas é mais comprometido com a verossimilhança, ele também é muito mais acessível para o leitor. Enquanto os outros autores ligados ao movimento comix buscavam referências gráficas diversas, como a arte psicodélica ou o expressionismo, Crumb construiu uma pictografia que, apesar de extremamente particular, se ancora quase que exclusivamente na tradição das histórias em quadrinhos e das ilustrações populares norte-americanas. Em entrevista concedida a Patrick Rosenkranz em 1998, o editor de quadrinhos Don Donahue demonstra a impressão contraditória entre anacronismo e vanguarda que permeia o trabalho de Crumb: "I thought he must be an old man, because that's the way it looked [...]. Maybe he'd been drawing for comic book back in the '20s or '30s and he went berserk or something" (ROSENKRANZ, 2002, p.69). Essa facilidade de leitura e a relação com o universo de convenções e estilos narrativos dos quadrinhos mais tradicionais, encontradas nas histórias de Crumb em grande medida explicam sua popularidade fora do ciclo específico de leitores de quadrinhos (underground ou convencional), bem como sua permanecia como criador após a desestruturação do movimento comix. 


\subsection{Estrutura narrativa}

A autobiografia é uma modalidade narrativa cujo surgimento é associado a um novo regime de sensibilidade decorrente dos conceitos modernos de identidade e vida interior. É certo que desde a antiguidade clássica existe um forte interesse do público pela vida de figuras ilustres (DOSSE, 2009, p. 124), mas a prática do autobiografismo era inconcebível em uma sociedade onde falar de si publicamente representava um tabu. Até mesmo as biografias efetuadas nesse período concentravam-se quase que exclusivamente nas proezas do biografado, relegando a vida particular a um papel acessório. Conforme François Dosse

É no século IV a.C. que encontramos testemunhos do lugar conquistado pela biografia na Grécia antiga. Vemos, com efeito, um surto de informações de ordem biográfica nos epigramas funerários. [...] Isócrates e Xenofonte surgem como pioneiros nesse campo, com escritos biográficos cujo objetivo é relatar a vida política de suas personagens, deixando na sombra sua vida privada (DOSSE, 2009, p.124).

Esse modelo de abordagem equivale à idade heroica da biografia, que se preocupava mais em representar modelos exemplares de conduta, honra e moral, que em reconstituir exaustivamente a cadeia de eventos que constituem a experiência de vida do biografado. Assim, a biografia não se ocupava em "retraçar apenas a 'vida', mas também a 'maneira de viver'” (DOSSE, 2009, p.123). O projeto Vidas Comparadas (ou Vidas Paralelas), desenvolvido por Plutarco no século I d.C., exemplifica a função da biografia de extrair ensinamentos e lições morais da vida dos grandes homens já que, tomada em sua singularidade, nenhuma vida pode ser comparada a outra.

Durante muito tempo, da Antiguidade à época moderna, o gênero biográfico teve por função essencial identificar. Prestou-se ao discurso das virtudes e serviu de modelo moral edificante para educar, transmitir os valores dominantes às gerações futuras. $\mathrm{O}$ gênero biográfico participa, pois, de um regime de historicidade no qual o futuro é a reprodução dos modelos existentes, que devem perpetuar-se. Inscreve-se, durante esse longo período, no respeito 
absoluto a uma tradição que se organiza na Antiguidade em torno dos valores heroicos: em seguida, com a cristianização, os valores religiosos é que difundem tomando por modelo as vidas exemplares (DOSSE, 2009, p.123).

Esse primeiro modelo de biografia destaca-se pelo caráter plano de sua abordagem, que elimina qualquer dado conflitante em função de um retrato exemplar. Sua narrativa é conduzida na exterioridade da ação, de forma que os grandes feitos e as demonstrações públicas de caráter e valores morais assumem um lugar central. Havia, portanto, total desinteresse pela vida interior do biografado e, em certo sentido, a própria noção de sondagem da experiência particular do indivíduo era uma preocupação alheia aos escritores que abordavam a "vida" como tema para a narrativa. Um trecho de biografia de César, efetuada por Plutarco, exemplifica o tom formal e o estilo de "relatório":

2. Sua expedição contra os britanos foi célebre pela audácia, pois foi o primeiro a penetrar com uma frota no Oceano ocidental e a navegar através do Atlântico para uma guerra 3. Ele empreendeu ocupar uma ilha de incrível grandeza que tinha ocasionado grande discórdia entre numerosos escritores; alegava-se que nome e forma tinham sido forjados, porquanto a ilha não existira nem existia atualmente. César fez assim avançar a supremacia romana além dos limites do mundo habitado (PLUTARCO, 2007, p.183).

Na biografia heroica, o indivíduo funciona quase que como um mecanismo narrativo, um mote para a condução da trama. Em nenhum ponto sua vida particular ou suas experiências pessoais são abordadas, apenas a figura exemplar do homem público é legada para a posteridade. A transformação desse modelo para a abordagem propriamente autobiográfica relaciona-se com o deslocamento da introspecção para o centro do interesse da esfera pública. Conforme Peter Gay, a introspecção sempre esteve na pauta das preocupações humanas, sendo tematizada por uma série de autores, como Platão, Marco Aurélio, Montaigne, Jean-Jacques Rousseau e Santo Agostinho (GAY, 1999, p.14). Nesse contexto, as Confissões de Santo Agostinho e Rousseau ocupam um lugar privilegiado como as primeiras tentativas de construir um modelo autobiográfico (WATT, 2010, p.79). 
Contudo, essas Confissões, contraditoriamente afastam-se da sondagem da vida interior e da experiência do indivíduo em função de projetos filosóficos mais amplos. Em Santo Agostinho encontramos uma profunda reflexão teológica onde a vida é percebida como o espetáculo da vontade de Deus. O autor, em toda obra, sequer assume um papel ativo nas ações desempenhadas durante a vida, colocando-se sempre como um objeto deslocado por uma força superior. Conforme Riolando Azzi, em Santo Agostinho o próprio sentido da palavra confissão não corresponde ao significado atual, já que "ele usa o termo em sentido bíblico. 'Confiteri' é reconhecer a própria fraqueza e miséria, mas implica principalmente a proclamação da misericórdia e da glória de Deus" (AZZI, 2012, p.17). Azzi destaca ainda que, dentro da tradição religiosa, as Confissões de Santo Agostinho funcionaram como uma espécie de itinerário de fé, já que demonstra principalmente a conversão de um homem dissoluto (AZZI, 2012, p.20). Assim, em Agostinho não encontramos o primado da experiência do indivíduo das autobiografias modernas, mas o percurso da "alma".

Dentro da tradição da autobiografia, a relação entre a sondagem da vida interior e o autoexame de consciência do cristianismo perdura. Segundo Ian Watt (2010, p.79), essa tradição já está presente no cristianismo primitivo e nas confissões, mas se fortalece com a tradição individualista do protestantismo. Com efeito, a primeira autobiografia laica foi escrita por Rousseau, um autor de formação calvinista. Em suas Confissões, Rousseau introduz pela primeira vez o primado do eu sobre a construção narrativa.

Se santo Agostinho começa suas memórias invocando a divindade - "Tu és Grande, Senhor!" -, Rousseau inicia a autobiografia na primeira pessoa do singular, insistindo em que ninguém antes dele tinha falado sobre si, nem alguém poderia fazê-lo no futuro, com maior honestidade (GAY, 1999, p.124).

Mesmo no modelo de autobiografia de Rousseau, é possível encontrar indícios de uma exploração da consciência que ultrapassam a experiência do indivíduo. Primeiramente, suas Confissões são englobadas por um projeto filosófico mais amplo e tentam justamente compor uma reflexão acerca do Homem Puro, que 
num estado natural conhece a si mesmo intuitivamente (STAROBINSKI, 2011, p. 246). Rousseau "reivindica, para o viajante e para o aventureiro que foi, o privilégio de um melhor conhecimento da humanidade, a posse de um saber mais vasto, mais diverso e mais eficaz" (STAROBINSKI, 2011, p.253). Em segundo lugar, Rousseau constrói sua autobiografia como um projeto extremamente amplo, que serviria como "peça de comparação" para outros homens e objeto de estudo para os filósofos (Ibidem, 2011, p.256). As Confissões de Rousseau, embora relatem acontecimentos de sua vida de forma direta e, para a época, um pouco chocante, são fundamentalmente uma obra filosófica que aborda as ideias de seus trabalhos anteriores (como Emílio, ou Da Educação) a partir da perspectiva de sua própria existência.

A obra de Rousseau carrega o prenúncio do Romantismo, movimento que entre os séculos XVII e XIX propunha justamente um retorno a uma visão de mundo centrada no indivíduo, valorizando a introspecção como principal forma de análise da experiência humana. Segundo Gay, essa tendência à introspecção chega a seu auge durante o século XIX, "que produziu um número muito maior de autobiográficos - e de leitores desse gênero - do que quaisquer dos séculos anteriores" (GAY, 1999, p.119). Gay acrescenta ainda que "o crescente interesse científico pelos sonhos, o uso de drogas, a loucura e as paixões sexuais desviadas da normalidade eram outros sintomas dessa tendência à introspecção" (GAY, 1999, p.12). Isso denota uma importante transformação na mentalidade burguesa, já que introduz uma perspectiva de individualidade emocional tradicionalmente desprezada por essa classe.

Nessa época, a arte de ouvir música e poesia se desenvolveu em uma postura de ardor quase religioso; as idéias românticas sobre o amor garantiram um público numeroso, pouco crítico. Foi também uma época em que as autobiografias e os auto-retratos, biografias, romances e obras históricas sobre o caráter das pessoas adquiriram a força de consideráveis indústrias domésticas; em que os diários e a correspondência íntima se tornaram mais comuns e mais reveladoras do que nunca. E, ao mesmo tempo, uma época em que os que perturbavam a paz burguesa, como Marx, Nietzsche e Freud, complicavam o modo como o "eu" percebe o mundo e responde a seus estímulos (GAY, 1999, p.16). 
Nesse período já é possível identificar obras autobiográficas que se afastam dos modelos teológicos/filosóficos, se preocupando apenas na experiência vivida. Em 1821, por exemplo, é publicado na Inglaterra Confissões de um Comedor de Ópio (Confessions of an English Opium-Eater), de Thomas De Quincey, relato literário da vida de um homem atormentado pelo vício. De Quincey, embora mostre no título que segue a tradição das "Confissões", aborda suas experiências de forma completamente individualista, não se confessa a um Deus ou tenta construir um conto de alerta moral. O próprio mote da exploração de estados alterados de consciência aponta para uma tendência introspectiva onde a experiência não serve para outro fim senão o próprio relato.

As similaridades entre o desenvolvimento da autobiografia em quadrinhos e da autobiografia tradicional são extensas. Primeiramente, assim como o florescimento da autobiografia no século XIX possui uma relação direta com o desenvolvimento de uma nova concepção do "eu", a autobiografia nos quadrinhos surge como resposta a uma concepção de vida interior derivado das profundas mudanças culturais que aconteceram nos Estados Unidos a partir da década de 1960. É certo que durante o século XX relatos autobiográficos, de famosos ou anônimos, gozaram de grande popularidade e êxito comercial. O que o modelo da autobiografia em quadrinhos introduz nesse contexto é uma perspectiva única, centrada numa experiência de interioridade que responde a transformações sociais, como a revolução sexual, uso recreativo de drogas psicodélicas, o movimento pelos direitos civis, feminismo, etc. Além disso, identificamos também uma continuidade na relação autobiografia $\mathrm{x}$ religião encontrada nas "Confissões".

Crumb e Justin Green, particularmente, apresentam essa característica em boa parte de sua obra autobiográfica. Witek destaca que Brown Meets the Holy Virgin Mary é fundamentalmente o relato confessional das neuroses causadas por uma educação católica traumática (WITEK, 1989, p.128). Em Crumb também encontramos diversas alusões à sua criação católica, particularmente no que se refere à prática da confissão de pensamentos impuros (My Troubles with Women, Zap $\mathrm{n}^{\circ}$ 10, 1982) e à culpa decorrente de suas fantasias masturbatórias no início da adolescência (My Troubles with Woman part II, Hup nº1, 1986). Sintomaticamente, na história autoficcional The Adventure of R. Crumb Himself (1973, Tales From the Leather Num) Crumb escapa por pouco de ser castrado por uma freira com cutelo em riste. O mote das "Confissões" também é retomado textualmente no título da 
história The Confessions of R. Crumb (1972, The People Comics). Em um sentido mais amplo, o próprio impulso de Crumb em expor o lado mais sórdido de sua existência também remete à sua culpa católica. Gravett resume a questão da seguinte forma:

Crumb's Catholic roots seem to have instilled in him an appetite for guilt and a need to confess his sins regularly. But instead of finding forgiveness in the privacy of the confessional booth, Crumb feels compelled to mull over them again and again by putting them down on paper as commix all to read (GRAVETT, 2005, p.172).

Disso resulta a seleção feita por Crumb dos eventos da vida a serem abordados nas narrativas autobiográficas. É certo que a vida de qualquer ser humano é permeada por eventos agradáveis, momentos especiais que perduram na memória, mas Crumb parece se deleitar em chafurdar justamente sobre o lado sórdido da vida. $\mathrm{Na}$ história Memories are made of this (1988, Weirdo $\left.\mathrm{n}^{\circ} 22\right)$, por exemplo, encontramos um relato perturbador de como o autor se aproveita da embriaguez de uma amiga para abusar sexualmente dela (Figura 22). Na última vinheta desse quadrinho o autor novamente faz alusão a sua compulsão pela confissão: "Why do I have this compulsion to confess?! Guess it's my catholic upbringing...”.

Analisando as histórias de Crumb numa perspectiva mais ampla é possível perceber o quanto sua autobiografia aborda o sexo como mote central. Em seus enxertos autobiográficos em prosa, encontrados em diversas publicações, como na série The Complete Crumb (1987 - 2005) e The R. Crumb Coffee Table Art Book (1997), o autor comumente fala de sua infância, da experiência de desenhar exaustivamente quadrinhos com seus irmãos, de sua vida familiar, de suas leituras, etc. Esse tema é pouco explorado em sua obra quadrinhística que, de forma recorrente, aborda suas experiências sexuais reais ou imaginárias. Em muitos sentidos essas histórias são a autobiografia de sua vida sexual. Na autobiografia em quadrinhos, o autor acaba sempre fazendo um seleção entre um grande corpus de experiências em função do que mais o interessa, preocupa ou aflige: Green fala sobre seu distúrbio obsessivo-compulsivo não diagnosticado e culpa católica; Art Spiegelman sobre o espectro do Holocausto projetado numa geração de judeus 
criados nos Estados Unidos; Joe Sacco aborda principalmente sua relação particular com o jornalismo, a cobertura noticiosa, etc (nesse sentido, a história autobiográfica "Como amei a Guerra", publicada na revista Yahoo, é exemplar); Crumb, por sua vez, parece se interessar quase que exclusivamente por sexo.

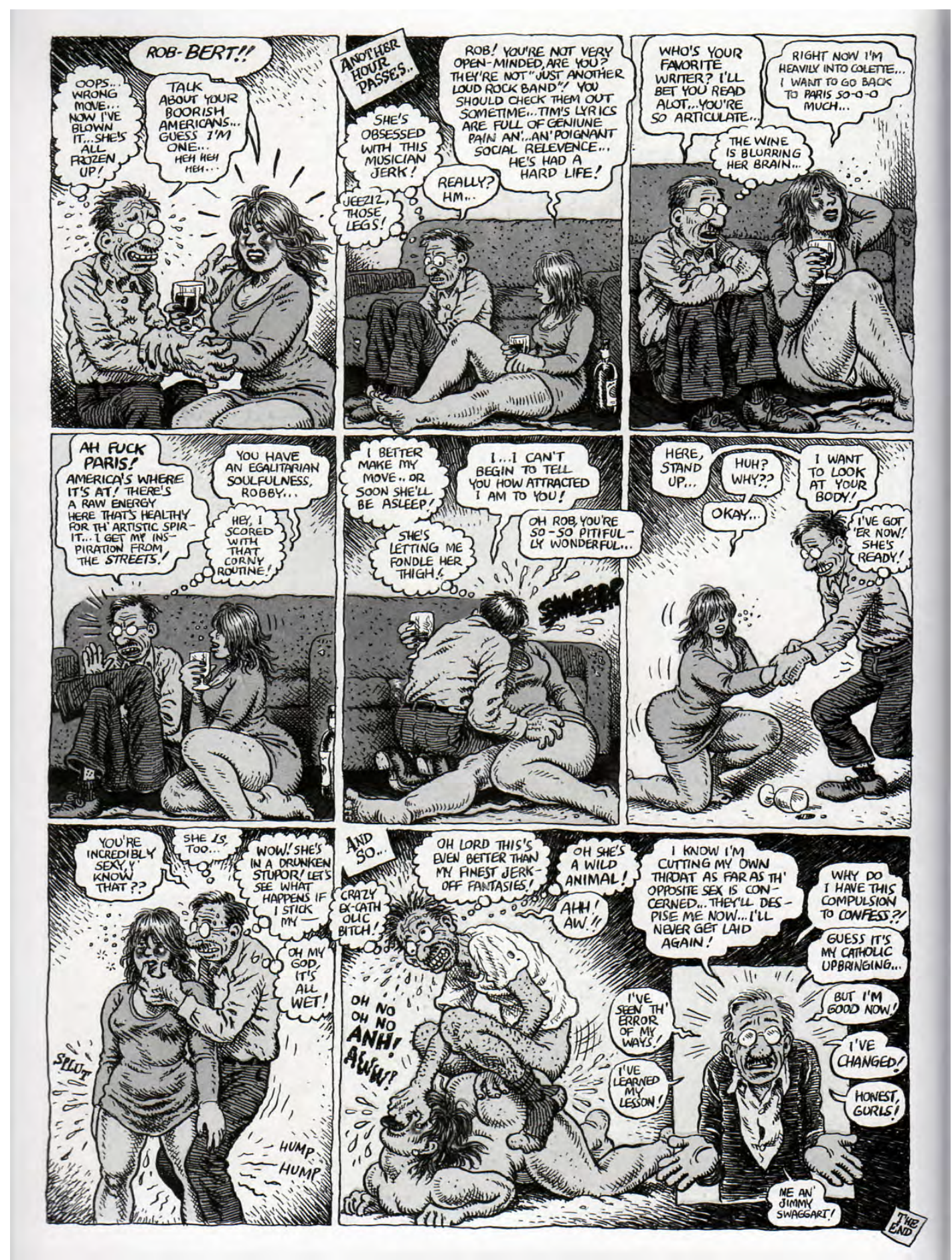

Figura 22 - Memories are made of this 
Outra característica marcante do modelo de autobiografia desenvolvido por Crumb diz respeito ao lapso temporal entre o acontecimento e o relato. Enquanto tradicionalmente a autobiografia é escrita por um indivíduo maduro, muitas vezes idoso, que confronta um "eu" jovem, Crumb utiliza-se frequentemente de experiências recentes como matéria para suas narrativas. Segundo Gay

Tornou-se uma obviedade dizer que a autobiografia é necessariamente o resultado de uma consciência dupla. Ao lembrar o passado, uma autobiógrafo já idoso, ou pelo menos próximo da velhice, confronta um "eu" mais jovem, e ambos, normalmente associados por um trégua instável, vão deixar sua marca na memória impressa". (Gay, 1999, p.153).

Essa falta de distanciamento que ora identificamos em Crumb denota um deslocamento interessante, de um modelo que tradicionalmente visa dar conta de toda uma experiência de vida para uma abordagem episódica de eventos. Mesmo que não enfraqueça o teor memorialístico, esse modelo episódico ressalta o quanto a autobiografia em quadrinhos possui uma função de expressão artística. Essa modalidade de expressão, antes de qualquer coisa, é uma manifestação que se põe a abordar a vida como matéria para arte. Esse estilo de abordagem o aproxima de outros escritores contemporâneos que utilizam-se de suas experiências como mote para narrativa. A semelhança entre o trabalho de Crumb e o do escritor Charles Bukowski, por exemplo, é um dado que deve ser devidamente problematizado. Conforme Howard Sounes, Crumb e Bukowski se conheceram por volta de 1972 e, aparentemente, se deram muito bem, fato impressionante se considerarmos que ambos eram pessoas difíceis no trato social (SOUNES, 2000, p.133). Desse contato iniciou-se uma breve colaboração, em que Crumb ilustrou dois livros autobiográficos de Bukowski: Bring Me Your Love (1983) e The Captain is Out to Lunch and the Sailors Have Over the Ship (1998) (SOUNES, 2000, p.325). É difícil verificar até que ponto essa foi uma influência concreta sobre o trabalho de Crumb, mas existem elementos que se repetem na autobiografia dos dois autores: abordagem episódica de eventos da vida; humor autodepreciativo; propensão a abordar o lado sórdido da vida; e obsessão pelo sexo oposto. O certo é que ambos estendem a noção de autobiografia 
para além da questão memorialística, utilizando-a como uma categoria que se constitui como uma forma de expressão artística.

Esse tipo de abordagem que privilegia experiências fragmentadas em detrimento da construção diegética do que propriamente se pode chamar de uma "vida" acaba por influenciar a construção de suas narrativas autobiográficas. Não encontramos em Crumb nenhuma narrativa longa que tente dar conta de algum período específico de sua vida, projeto levado a cabo por diversos outros quadrinhistas, como Harvey Pekar em Cleveland (2012) e The Quitter (2005), por exemplo. Na autobiografia de Crumb identificamos dois tipos de estruturas narrativas, sempre desenvolvidas em poucas páginas: episódica, onde o autor aborda um evento em particular e segue um orientação temporal rígida (Memories are made of this, All true story: my first LSD trip, Theasure Island days); e temática, onde o autor elege um tema específico e constrói a narrativa utilizando saltos temporais ( $M y$ troubles with women, I remember the sixties, I'm grateful, I'm grateful, Footsy). Em ambos os modelos encontramos um tipo bastante tradicional de narrativa, normalmente conduzida pelo textos dos recordatórios ou pelo fluxo de pensamento do autor. Assim como Crumb revisita os quadrinhos clássicos para construir seu estilo pictográfico, também sua narrativa remete a um tipo mais convencional de quadrinho, com uma orientação temporal rígida e um tema central a ser explorado. Ao contrário de alguns de seus companheiros do movimento comix, como Rick Griffin e Victor Moscoso, Crumb sempre conduz sua trama com clareza e objetividade, utilizando os recordatórios para situar o leitor e conduzir saltos temporais de forma suave. Novamente, entra em questão o quanto sua obra é acessível para o leitor não familiarizado com o universo dos quadrinhos, uma vez que, desconsiderando as temáticas extremas e o tratamento explícito, suas histórias simulam o mesmo tipo de histórias em quadrinhos lidas pelo autor durante a infância, destacando-se a influência de diversos autores de quadrinhos, como Carl Barks, Walt Kelly e Harvey Kurtzman.

A despeito do caráter convencional de suas narrativas, os quadrinhos de Crumb transmitem uma impressão geral de improviso quando comparados aos quadrinhos comerciais. Em termos de enredo, não existe uma preocupação em instruir uma intriga, nem um desfecho significativo: a trama é conduzida de forma intuitiva, com uma situação que leva a outra, até o termino da história (que muitas vezes não faz o menor sentido, nem possui uma gag identificável). Esse tipo de 
abordagem normalmente é associado a quadrinhos que são executados sem um roteiro prévio. De fato, Crumb corrobora essa proposição quando fala de seu processo criativo:

My approach to comics has always been somewhat spontaneous. I'm usually only a few panels ahead - I don't like to plan it out much. Otherwise the labor involved in the drawing becomes boring, tedious. I just can't do it. It's not in me... Maybe I'm lazy... So be it... I kind of resolve the story in my mind as I draw (CRUMB, 1997,p.247).

Esse falta de planejamento causa efeitos interessantes. Alguns deles são problemáticos, como na história Mr. Natural committed to a mental Institution!, que após meses sendo publicada serialmente no jornal Village Voice acaba repentinamente com o próprio autor aparecendo no quadrinho e explicando que a trama ficaria inconclusa. No caso da autobiografia, essa condução intuitiva torna-se benéfica, já que o autor consegue acessar suas recordações de forma orgânica. Além disso, a ausência de roteiro definido impede que Crumb omita dados que, após uma observação criteriosa que se valesse de um mínimo de bom-senso, ficariam de fora da trama. Disso decorre esse modelo de autobiografia tão sincera, visceral e patética. 


\section{CAPÍTULO III - AS HISTÓRIAS EM QUADRINHOS NO BRASIL}

\subsection{A formação do mercado editorial de quadrinhos no Brasil}

Os quadrinhos no Brasil possuem uma tradição que remete às revistas ilustradas do século XIX. Conforme Carlos Costa, ainda na primeira metade do século XIX periódicos como A Lanterna Mágica (1944-1945) começam a introduzir uma cultura da imagem junto ao leitor, "desenvolvendo uma forte demanda pela informação visual" (2012, p.111). Nas décadas seguintes, as revistas semanais de orientação humorísticas consolidam-se como modelo de publicação rentável, aumentando a demanda por caricaturistas, litógrafos e artistas gráficos. Nesse contexto, destaca-se o trabalho precursor do italiano radicado no Brasil Angelo Agostini. Ilustrador de traço refinado e particular, Agostini trabalhou numa série de publicações de destaque, como Diabo Coxo, O Cabrião e Revista Illustrada, onde introduziu uma forma de criação gráfica bastante semelhante aos quadrinhos contemporâneos, Agostini também foi responsável pela criação da primeira série de quadrinhos brasileiros com personagem fixo. As Aventuras de Nhô Quim, ou Impressões de uma viagem à Corte, publicado pela primeira vez no jornal Vida Fluminense, edição 57, de 30 de janeiro de 1869 (MOYA, 1993, p.16). Segundo Waldomiro Vergueiro, Agostini "foi um grande precursor dos quadrinhos no país e sua arte pode ser comparada, às vezes com vantagem, a outros que, como ele, viveram no século XIX, destacando-se artistas como Töpffer, Bush, Swinnerton ou Colomb" (2011, p.14). De fato, Agostini já demonstrava uma grande sofisticação no modo como construía a narrativa sequencial entre os quadros, bem como uma boa intuição do que se tornaria um formato mercadológico viável. Na primeira página de As Aventuras de Nhô Quim (Figura 23), próximo ao título, lê-se a frase "História em muitos capítulos", que já anunciava a projeto de construir uma narrativa seriada aos moldes dos folhetins publicados na época. Embora não utilizasse balões ou ângulos diversos (existe uma tendência a sempre representar as personagens de corpo inteiro, sem closes ou cortes, como era típico na ilustração e na caricatura da época), essa primeira página também demonstra a forma original com que o autor utilizava expedientes gráficos inéditos para construir a narrativa, como na vinheta catorze, 
onde a entrada do trem em um túnel é representada por um quadro completamente negro.

Agostini também esteve envolvido na criação do periódico O Tico-Tico, em 1905, considerada a primeira revista em quadrinhos do Brasil (MOYA; OLIVEIRA, 1977, p. 202; VERGUEIRO, 2011, p.14-16). Além de criar o logotipo (Figura 24), Agostine foi um colaborador regular nos primeiros anos da publicação. Segundo Gilberto Maringoni, Agostini havia sido responsável pela introdução de histórias em quadrinhos destinadas a crianças no Brasil, publicando no ano anterior a história Por Causa de um cachorro (Conto para crianças), no jornal O Malho (2011, p.226-227). A iniciativa era pioneira, já que na imprensa brasileira não existia tradição de publicações destinadas a crianças. Em seu estudo acerca das publicações do século XIX, Costa identificou apenas uma revista destinada a crianças, a didática A Infância, publicada em 1879 e que durou apenas um número (2012, p.266). Álvaro de Moya (1996, p.33) e Maringoni (2011, p.228) citam ainda o Jornal da Infância, publicada em 1898, também de curta duração. O Tico-Tico, por outro lado, foi um sucesso comercial imediato, alcançando a tiragem de 25 mil exemplares na primeira edição (MARINGONI, 2011, p.229), número bastante considerável para a época.

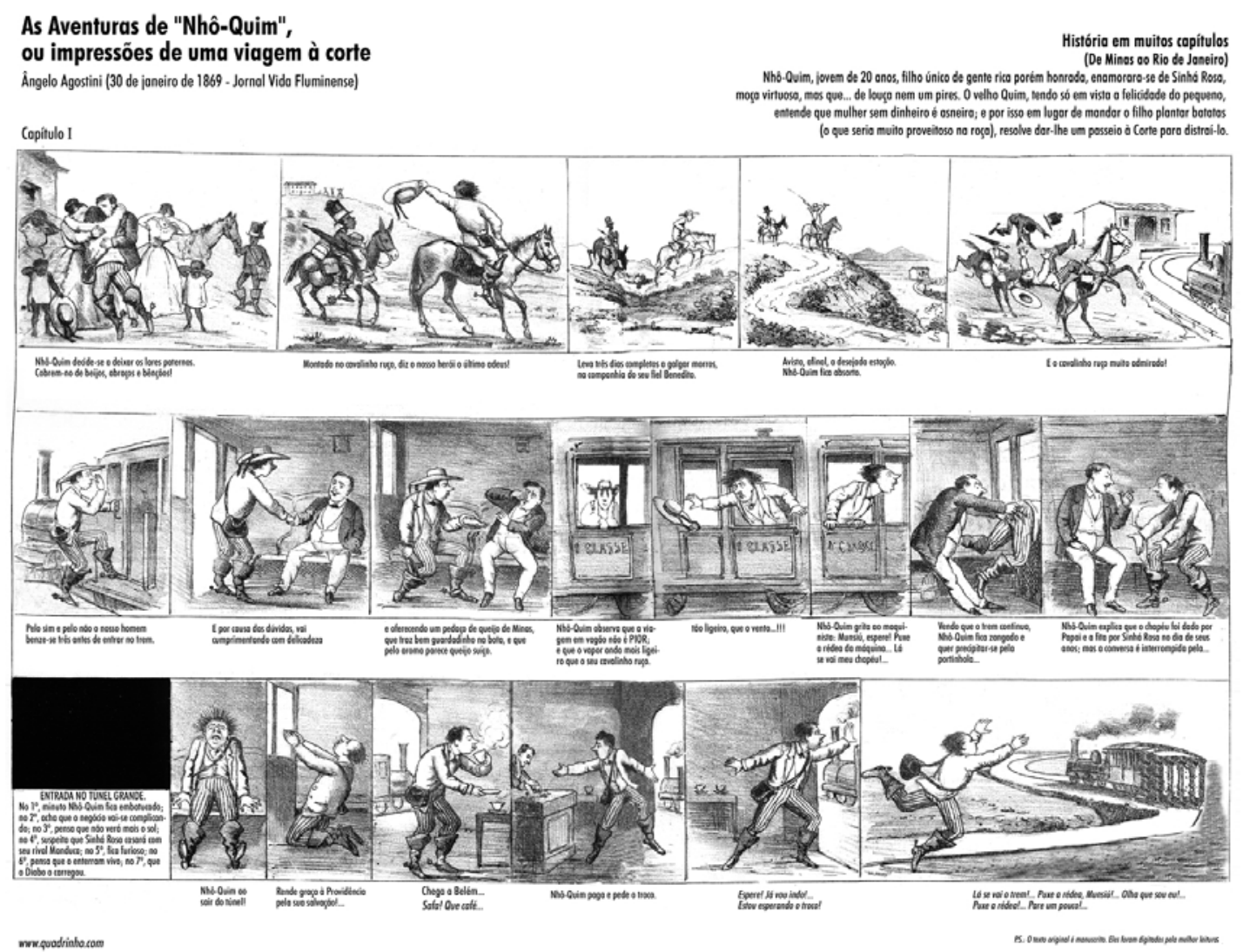

Figura 23 - As Aventuras de Nhô Quim 


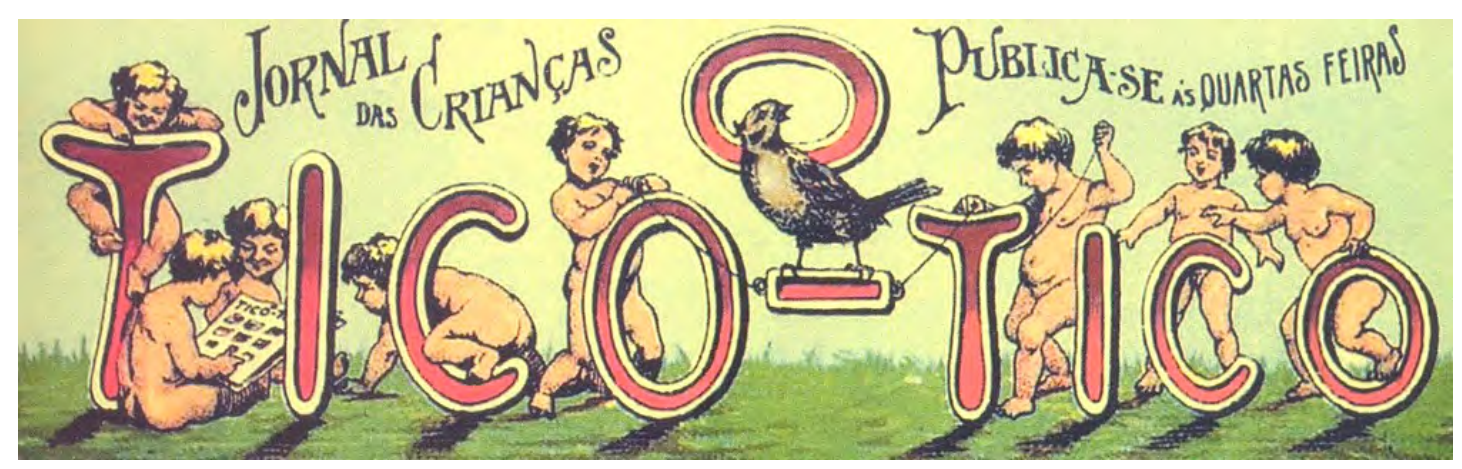

Figura 24 - Logotipo de O Tico-Tico

A revista $\mathbf{O}$ Tico-Tico também se mostrou longeva, sendo publicada até o início da década de 1960. Sua estrutura bastante diversificada, semelhante a um almanaque, investia em diversos gêneros para atrair a atenção do público. Conforme Vergueiro

Elaborada no estilo europeu, a revista $O$ Tico-Tico não era exclusivamente de quadrinhos, mas trazia também contos, passatempos, poesias, matérias sobre datas comemorativas, etc. Desde seu início, no entanto, inseriu a história em quadrinhos e suas páginas, possibilitando aos leitores brasileiros o contato com vários personagens dos comics norte-americanos do século XX [...] (VERGUEIRO, 2011, p.15).

A publicação de $\mathbf{O}$ Tico-Tico, portanto, dá início à relação entre os quadrinhos norte-americanos e o mercado brasileiro, que se fortaleceria com a introdução dos suplementos de jornais durante a década de 1930. Segundo Vergueiro, A Gazetinha, suplemento infantil do jornal A Gazeta lançado ainda em 1929, já trazia comics, como Little Nemo in Slumberland, Brick Bradford, The Phantom e Barney Baxter (2011, p.17). Gonçalo Junior cita também a experiência editorial do suplemento Mundo Infantil, da Editora Vecchi, lançada no mesmo ano (2004, p.48). Contudo, o marco na implementação do modelo mercadológico dos suplementos de jornais acontece em 1934, com o lançamento de Suplemento Infantil, do jornal A Nação (VERGUEIRO, 2011, p.18-19; OLIVEIRA; MOYA, 1977, p.202-203.). O Suplemento Infantil surgiu por iniciativa do jornalista Adolfo Aizen, figura que se tornaria central no mercado de quadrinhos do Brasil até o início da década de 1960. No ano anterior, Aizen havia feito uma viagem aos Estados Unidos, onde percebeu o 
enorme sucesso dos suplementos de quadrinhos no jornal. Voltando ao Brasil, decidiu iniciar uma empreitada semelhante, propondo ao seu ex-patrão Roberto Marinho a criação de um suplemento de quadrinhos para o jornal O Globo. Frente a falta de interesse de Marinho, acabou valendo-se de sua amizade com João Gilberto, então Interventor Federal nomeado pelo Presidente Getúlio Vargas, para concretizar o projeto no jornal A Nação.

O Suplemento Infantil publicava os comics mais populares na época, como Mandrake, Flash Gordon e Dick Tracy, alcançando grande sucesso junto ao público. Após alguns meses de publicação, o suplemento foi descontinuado, voltando como uma edição autônoma (que poderia ser encartada a qualquer jornal que se interessasse por agregar o conteúdo a sua publicação) e renomeado como Suplemento Juvenil. Segundo Gonçalo Junior, Aizen novamente utilizou-se da sua amizade com o influente João Gilberto para conseguir financiar essa nova empreitada, que se chamaria Grande Consorcio de Suplementos Nacionais (2004, p.33-34)

Frente à grande popularidade do suplemento de Aizen, nos anos seguintes surgiram várias publicações semelhantes, destacando-se a investida de Roberto Marinho, com a criação do Globo Juvenil. “A concorrência ficou muito acirrada. Cada publicação tentava apresentar personagens que agradassem aos leitores, criando campanhas de marketing bastante agressivas para a época" (VERGUEIRO, 2011, p.21). Em 1939, Aizen inova novamente, introduzindo o modelo do comic book no mercado, com a criação da revista Mirim, impressa no formato meio-tabloide (OLIVEIRA; MOYA, 1977, p.205; JUNIOR, 2004, p.67). A iniciativa também foi seguida por Marinho, que no mesmo ano lançou a Gibi, cujo título viraria um sinônimo para revista em quadrinhos.

Durante a década de 1930, o mercado de histórias em quadrinhos se consolida no Brasil e a grande popularidade dessa mídia entre crianças e adolescentes acaba por atrair a atenção de pais, professores e autoridades religiosas. Esse processo acabou por revelar a existência de um ambiente culturalmente hostil aos quadrinhos. As críticas destinadas aos quadrinhos no Brasil seguem um percurso semelhante ao identificado nos Estados Unidos, que vão dos malefícios no aprendizado das crianças ao incentivo à delinquência juvenil. O contexto brasileiro introduz ainda a acusação de que os comics produziam um efeito "desnacionalizante" sobre as crianças. Conforme Gonçalo Junior: 
No Brasil, os primeiros inimigos declarados dos quadrinhos foram os padres, que importaram da Itália a tese de que os comics americanos "desnacionalizavam" as crianças. Como muitos imigrantes italianos, eles acompanhavam preocupadamente pelos jornais que assinavam o esforço dos educadores em banir do território italiano os quadrinhos americanos (GONÇALO JUNIOR, 2004, p.77).

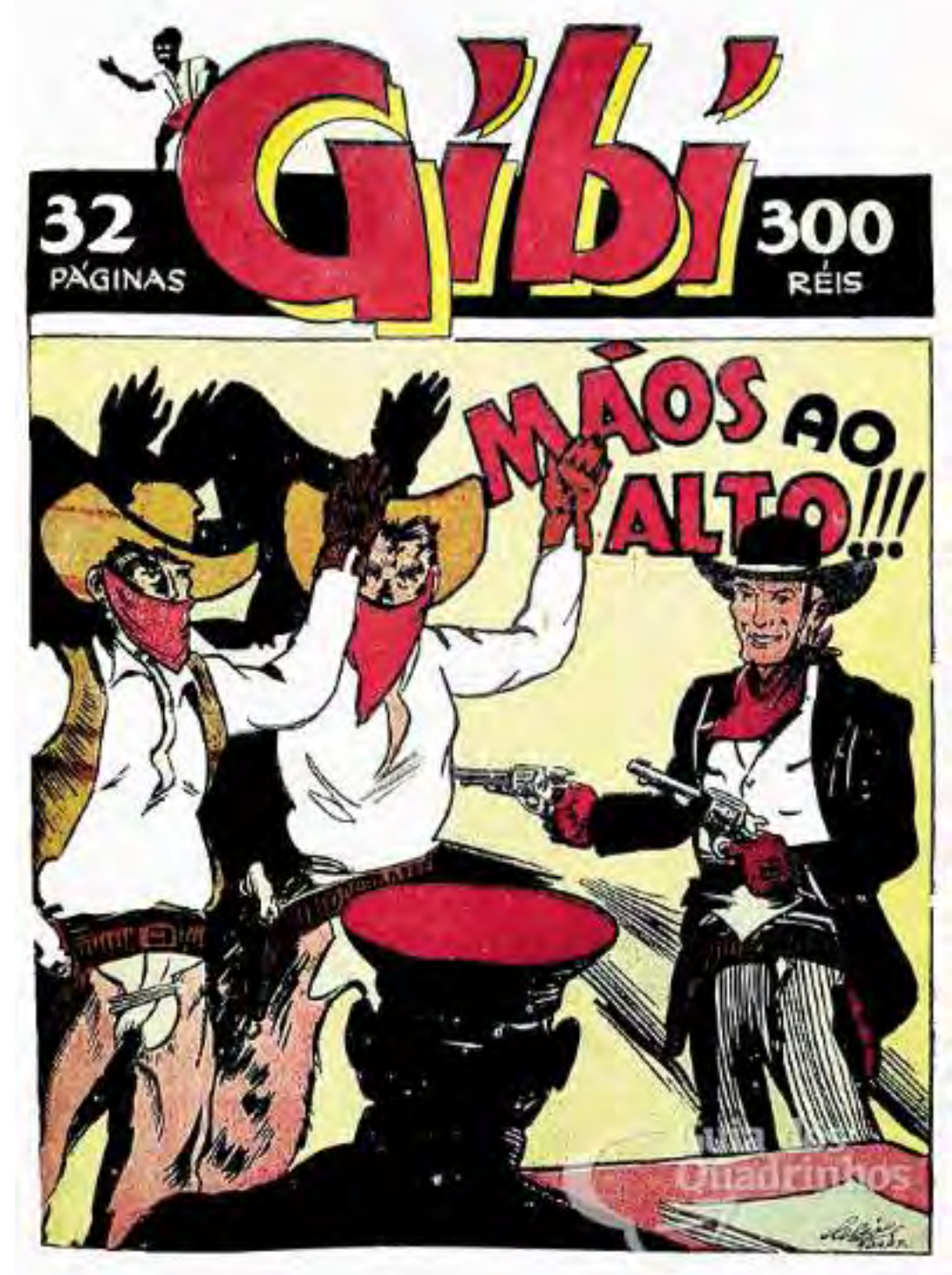

Figura 25 - Gibi n² (1939)

No que se refere à questão educacional, era comum encontrar na imprensa geral e nos jornais de orientação católica artigos acerca dos efeitos nefastos dos quadrinhos sobre a mente dos jovens. As acusações eram muitas, conforme sintetiza Vergueiro: 
Apesar de sua imensa popularidade junto ao público leitor composto principalmente por jovens e adolescentes - e das altíssimas tiragens das revistas, a leitura de histórias em quadrinhos passou a ser estigmatizada pelas camadas ditas "pensantes" da sociedade. Tinha-se como certo que sua leitura afastava as crianças de "objetivos mais nobres" - como o conhecimento do "mundo dos livros" e o estudo de "assuntos sérios" - que causava prejuízos ao rendimento escolar e poderia, inclusive, gerar consequiências ainda mais aterradoras, como o embotamento do raciocínio lógico, a dificuldade para apreensão de idéias abstratas e o mergulho em um ambiente prejudicial ao relacionamento social e afetivo dos leitores (VERGUEIRO, 2007, p.16).

Em grande medida, as próprias instituições educacionais ligadas a setores do governo corroboravam essa ideia. Gonçalo Junior (2004, p.114) faz um interessante relato nesse sentido: em 1944, Instituto Nacional de Estudos Pedagógicos (INEP), publica na Revista Brasileira de Estudos Pedagógicos uma pesquisa cujas principais conclusões diziam respeito à preguiça mental e aversão aos estudos que os quadrinhos proporcionariam nos estudantes. Uma análise das publicações efetuada também sugeria que muitos temas e representações eram impróprias para crianças e adolescentes, particularmente a forma "lasciva" como as mulheres eram desenhadas e a violência encontrada nas publicações. Em outra pesquisa realizada com estudantes, o INEP descobriu ainda que muitos jovens apontavam personagens dos quadrinhos como as figuras mais conhecidas da história brasileira. "Heróis 'inventados' como Flash Gordon, O Fantasma e Brucutu apareciam na frente de nomes reais como Osvaldo Cruz, barão do Rio Branco, Olavo Bilac, almirante Tamandaré e o pintor Pedro Américo" (GONÇALO JUNIOR, 2004, p.115).

Apesar das críticas severas e das diversas tentativas de criar leis que impedissem sua comercialização, durante o Estado Novo nunca aconteceu uma censura efetiva aos quadrinhos. Conforme Gonçalo Junior, a perseguição aos comics pelo governo estaria de acordo com os preceitos do Estado Novo, fortemente influenciado por nacionalismo de orientação fascista (2004, p.83). O projeto nunca se concretizou devido a amizade entre Aizen e João Gilberto, cuja posição de poder havia se consolidado. Posteriormente, Marinho também aproximou-se do presidente Vargas, ocupando lugar no Conselho Nacional de Imprensa (CNI) (GONÇALO JUNIOR, p.86). Além disso, Aizen sempre se preocupou "com a aceitação das 
histórias em quadrinhos pelo povo brasileiro, principalmente por pais e professores" (VERGUEIRO, 2011, p.22-23).

Após fundar a EBAL (Editora Brasil América Ltda.), em 1945, Aizen mostrou-se bastante ciente das críticas destinadas às histórias em quadrinhos, lançando uma série de publicações que, mesmo que muitas vezes não se mostrassem comercialmente viáveis, ajudavam a melhorar a opinião pública em relação aos quadrinhos. Esse projeto parece metodicamente tentar contrapor todas as acusações em voga: frente à desnacionalização, as séries História do Brasil e Grandes Figuras do Brasil; as séries Edição Maravilhosa (com adaptações de clássicos da literatura para os quadrinhos) e Ciência em Quadrinhos visavam mostrar o potencial educativo dos quadrinhos; enquanto a Série Sagrada (que a cada edição trazia a vida de um santo) e O Antigo Testamento em Quadrinhos, foram concebidos sob medida para acalmar os ânimos das autoridades religiosas. Gonçalo Junior (2004) relata que Aizen utilizava também uma estratégia bastante original para melhorar a imagem dos quadrinhos: oferecia semanalmente na sede da Ebal um almoço para políticos e personalidades do mundo cultural, aproveitando a ocasião para mostrar todo o zelo e cuidado com que seus quadrinhos eram editados.

Enquanto Aizen se empenhava em contornar as críticas aos quadrinhos, Roberto Marinho sempre atraía atenção indesejada, processo que se intensificou quando chegaram ao país as ideias de psiquiatra Fredric Wertham. Conforme Gonçalo Junior (2004, p.238), em 1954 a edição brasileira da Reader’s Digest já trazia a compilação do primeiro capítulo do livro Seduction of the Innocent, com o apelativo título "História em Quadrinhos - Roteiro Para a Delinquiência". Não demorou para que Marinho fosse acusado de construir um império à custa da exploração de crianças e jovens, que partiam para uma vida de crime após a escola dos gibis. As críticas contra Marinho chamam atenção porque entre os títulos de aventura e ficção policial que ele publicava não havia nada que se assemelhasse às produções de terror e ficção científica que chamaram atenção do público norteamericano. Durante a década de 1950, essas histórias eram publicadas por editoras paulistas, como a La Selva e Orbis Publicações (SANTOS, 2011, p.64). A perseguição a Marinho, na verdade, tinha conotações mercadológicas. Enquanto Aizen limitava-se ao universo dos quadrinhos e das publicações infantis, Marinho já era detentor de um pequeno império de comunicação, com jornal, rádio e a Rio Gráfica e Editora (RGE, posteriormente Editora Globo). Seus concorrentes na 
imprensa viam os quadrinhos como um calcanhar de Aquiles, utilizando-os sempre que precisavam ataca-lo. Gonçalo Junior relata que, ainda durante o início da década de 1940, o empresário Orlando Dantas, do Diário de Notícias, publicou uma série de artigos contrários aos quadrinhos no intuído de atacar seu concorrente, chegando a citar as publicações Globo Juvenil e Gibi como especialmente nocivas (2004, p.134137). A situação se repetiu em 1953, quando uma verdadeira cruzada contra os gibis foi encampada por Samuel Wainer, do jornal Última Hora. Novamente existia o interesse de atingir Marinho que, numa série de reportagens, chegou a ser responsabilizado por crimes cometidos por jovens leitores de gibis. Essa campanha difamatória ganhou grande repercussão, principalmente pelas fotos que mostravam crianças em reformatórios lendo atentamente os quadrinhos publicados por Marinho (GONÇALO JUNIOR, p.209-219).

Em 1954 aconteceu a implementação do Comic Code Authority nos Estados Unidos e Aizen, sempre atento aos dissabores do mercado de quadrinhos, implantou sua própria versão do código de ética na EBAL. As histórias importadas passavam por um processo nacionalizante, onde cenários e nomes de personagens eram modificados para remeter à realidade brasileira. Mulheres que fossem desenhadas de maneira vagamente sensual também ganhavam roupas mais compostas. "Em vez de usar um selo, como nos Estados Unidos, [Aizen] colocou no canto superior esquerdo da capa de seus gibis uma classificação em cinco faixas etárias: "para crianças”, "para maiores de treze anos", "para moças e rapazes", "para adultos e "para todas as idades" (GONÇALO JUNIOR, 2004, p.257-258). Mesmo com todas essas medidas, os ataques aos gibis continuaram. Numa atitude um tanto quanto controversa, os próprios editores chegavam a atacar os gibis de terror das editoras paulistas, conforme relata Gonçalo Junior:

Era preciso separar o que era bom do que era mau quando se discutia a censura aos quadrinhos no Brasil. Assim insistiam Aizen e Marinho quando faziam a defesa enfática de suas revistas. Para isso, valia até se pronunciar publicamente contra determinadas revistas em quadrinhos que, garantiam eles, pouco tinham a ver com as suas. Os gibis de terror da La Selva e de outras pequenas editoras de São Paulo se tornaram alvo freqüente de críticas porque traziam histórias de horror com violentas cenas de morte (GONÇALO JUNIOR, 2004, p.278). 
Muitos quadrinhistas brasileiros aproveitaram esse momento de hostilidade contra os comics como mote para regulamentação da profissão no Brasil. Desde de início dos anos 1950 havia um movimento de artistas e entidades de classe, como a Adesp (Associação de Desenhistas de São Paulo) e a ABD (Associação Brasileira de Desenho), em função de uma lei de reserva para quadrinhos nacionais. Contudo, a maior parte dos editores considerava a ideia comercialmente inviável, já que a compra de materiais importados, via representantes diretos de editores (a Editora Record se destacava no licenciamento de séries estrangeiras) ou pelo syndicates, possibilitavam que se adquirissem produtos por uma fração do preço que o produto nacional custaria. Além disso, o material importado já estava previamente respaldado como sucesso comercial no seu país de origem. A abertura para profissionais brasileiros era bastante reduzida, limitando-se a capas, letreramento e retoques no material importado. A produção realmente criativa estava restrita a umas poucas séries aos moldes norte-americanos e ao pequeno espaço para ocasionais adaptações de clássicos da literatura brasileira, narrativas religiosas (histórias de Santos, da Bíblia, etc) e eventos da história do Brasil. Nesse contexto, a profissionalização dos roteiristas e desenhistas brasileiros de quadrinhos aconteceu justamente devido ao fim dos quadrinhos de terror das editoras norte-americanas, ocorrido após a implementação do Comic Code Authority. No Brasil, o gênero de terror gozava de grande popularidade e, uma vez esgotada a fonte de quadrinhos oriundos dos Estados Unidos, surgiu a necessidade de continuar a produção utilizando artistas brasileiros (OLIVEIRA, MOYA, 1977, p.231).

Em 1959, pela iniciativa Miguel Penteado e Jayme Cortez, aconteceu a tentativa de criar uma editora que publicasse exclusivamente quadrinhos de autores nacionais, fossem brasileiros natos ou estrangeiros que residissem no Brasil (OLIVEIRA, MOYA, 1977, p.226). A Editora Continental (posteriormente Editora Outubro) agregava uma série de artistas que nas décadas seguintes ocupariam um papel central nas histórias em quadrinhos, como Flávio Colin, Gedeone Malagola, Júlio Shimamoto, Nico Rosso e Mauricio de Sousa. A Editora publicava principalmente histórias de terror (Histórias do Além, Terror, Histórias Macabras, Seleções de Terror), adaptações de sucessos da rádio e TV (Vigilante Rodoviário, Capitão 7), além da revista infantil Bidu, primeira publicação de Mauricio de Sousa. 
Outra iniciativa de fazer quadrinhos nacionais aconteceu em 1962, com a fundação da CETPA - Cooperativa Editora e Trabalho de Porto Alegre. Conforme Eloar Guazzelli, essa cooperativa de quadrinhistas estava fortemente influenciada pelo modelo argentino e "buscavam abrir espaço para publicações que valorizassem 'o herói nacional', em um período marcado pela enorme presença de material importado" (2011, p.121). A editora atraiu grandes nomes do quadrinho nacional, como Julio Shimamoto, Flavio Colin e Renato Canini mas, apesar da excelente qualidade de seus títulos, encerrou suas atividades em 1963, principalmente devido má administração.

Embora as experiências com quadrinhos nacionais não se mostrassem particularmente animadoras, a articulação de uma reserva de mercado continuava a tramitar. Em 1963, o presidente João Goulart criou o decreto-lei no 52.497, que institua cotas para a produção nacional. "Pela lei, as editoras deveriam publicar, no conjunto de suas edições, histórias em quadrinhos nacionais nas seguintes proporções mínimas: 30\% a partir de janeiro de 1964; 40\% a partir de janeiro de 1965; e, por último, 60\% a partir de janeiro de 1966" (GONÇALO JUNIOR, 2004, p.365). Os grandes editores de histórias em quadrinhos, encabeçados por Roberto Marinho, Adolfo Aizen, Victor Civita (Editora Abril) e Assis Chateaubriand (Edições O Cruzeiro), entraram com um mandato de segurança, argumentando o caráter anticonstitucional da lei e a impossibilidade de cumprir os percentuais, dada a suposta ausência de profissionais brasileiros capacitados para substituir as produções estrangeiras.

O processo legal adiou a implementação da lei até que golpe militar que depôs o presidente João Goulart, em 31 de março de 1964, desarticulou a militância das entidades de classe dos profissionais dos quadrinhos. Muitos autores ligados à Adesp sentiram-se acuados com os novos tempos de repressão. Flavio Colin e Julio Shimamoto, por exemplo, migraram para a publicidade e só retornaram aos quadrinhos na década seguinte (GONÇALO JUNIOR, 2010, p.343). Mauricio de Sousa foi um dos poucos criadores que prosperaram sem maiores dificuldade durante a ditadura militar. Em 1966, os ministros do STF decidiram que a lei de reserva dos quadrinhos nacionais decretada por João Goulart era constitucional. Mesmo assim, a medida nunca foi posta em prática (GONÇALO JUNIOR, 2004, p. 383). 


\subsection{Quadrinhos e censura}

A década de 1960 é marcada por uma transição bastante significativa no universo dos quadrinhos, caracterizada pela maior diversificação temática, experimentalismo, ampliação das possibilidades narrativas e maior aproximação com o público adulto. Embora o mercado mainstream se mantivesse relativamente indiferente a essas novas tendências, é possível identificar sua articulação em manifestações diversas, como movimento dos comix nos Estados Unidos, os quadrinhos underground da revista japonesa Garo e a renovação dos quadrinhos europeus promovido por autores como Hugo Pratt e Philippe Druillet (DANNER, MAZUR, 2014). No caso do Brasil, a censura instaurada pela Ditadura Militar (19641985) impediu, em grande media, que, durante muitos anos, essas renovações encontrassem eco de forma irrestrita. O principal ponto de atrito entre novo modelo de produção quadrinhística (encontrado particularmente no underground norteamericano) e a censura diz respeito à crítica social e de costumes, identificada como subversiva pelo regime; e à utilização do sexo como pauta recorrente, mesmo que esse recurso nem sempre tenha intenções eróticas, mas principalmente como elemento de choque ou registro da mudança comportamental advinda da chamada "revolução sexual".

Durante a ditadura, mesmo revistas em quadrinhos bastante inócuas foram apreendidas ou canceladas por decisão editorial. Em 1964, por exemplo, a editora O Cruzeiro cancelou a revista Pererê, de Ziraldo Alves Pinto, apesar das boas vendagens e das críticas positivas de intelectuais que identificavam em suas narrativas um tipo genuinamente brasileiro de fazer quadrinhos (CIRNE, 1974). Levando em conta as inclinações políticas de Ziraldo, a preocupação principal da editora era que a censura identificasse algum conteúdo subversivo na publicação. De fato, a censura era exercida em tantas instâncias que os editores precisavam tomar um cuidado redobrado para evitar apreensão e os prejuízos decorrentes. Além dos aparelhos oficiais de censura e repressão, os juízes de menores também podiam proibir e recolher qualquer publicação que considerassem prejudiciais às crianças e adolescentes. Gonçalo Junior exemplificar esse fenômeno com um acontecimento bastante pitoresco: 
Em fevereiro de 1966, na cidade mineira de Juiz de Fora, as revistas Bolinha e Luluzinha (O Cruzeiro) e O Pato Donald (Abril), entre outras, foram consideradas prejudiciais às crianças pelo juiz de menores da cidade, João Grinalson da Fonseca. Segundo ele, havia relatos de que a meninada adotava "práticas condenáveis" para comprar revistinhas e figurinhas. Por considerar os personagens "maus elementos de formação", ele baixou um ofício a censura podia ser municipal - que atingiu também os donos de bancas e livrarias, com multa progressiva que começava em 200 cruzeiros e dobraria a cada infração nova - e o fechamento e a cassação da licença do estabelecimento por até seis meses - se vendessem gibis e figurinhas para menores de 16 anos (GONÇALO JUNIOR, 2010, p.140).

Os quadrinhos que de alguma forma abordassem temáticas sexuais eram ainda mais severamente repreendidos. O caso dos catecismos de Carlos Zéfiro é exemplar nesse sentido. Publicados desde a segunda metade da década de 1950, os catecismos eram revistas pornográficas semelhantes às tijuana bibles, populares nos Estados Unidos entre as décadas de 1930 e 1950. A diferença é que, enquanto as Tijuana Bibles satirizavam celebridades, políticos e personagens de cartoons, os catecismo de Zéfiro tinham uma abordagem bem mais cotidiana da pornografia, trabalhando com personagens e situações que se tornariam lugar-comum em sua produção: secretárias, primas, viúvas, enfermeiras, empregadas domésticas, maridos traídos, etc. O termo "catecismo" também chama atenção pela sua conotação religiosa, cuja apropriação tematiza dois aspectos: a semelhança do formato das revistinhas de Zéfiro (uma folha de ofício dobrada duas vezes) com os livretos religiosos; e ao nada inocente pressuposto de que ambas as publicações se destinavam a instrução da juventude, no âmbito religioso e sexual. As bancas brasileiras não publicavam nenhum tipo de revista erótica, de forma que os catecismos, vendidos de forma clandestina, realmente eram utilizados para satisfazer a curiosidade dos jovens e avidez dos apreciadores desse tipo de leitura (GONÇALO JUNIOR, 2004, p.322-323). Isso em grande medida explica a popularidade de Zéfiro que, apesar das visíveis limitações como desenhista (Figura 26), colocou no mercado um número estimado de 600 catecismos ao longo das três décadas em que esteve em atividade.

No regime militar a identidade de Zéfiro foi investigada "por delegados de polícia, agentes da Polícia Federal e de órgãos ligados à repressão" (GONÇALO JUNIOR, 2004, p.319). Como os catecismos obviamente não possuíam dados referentes aos editores, nunca se comprovou a autoria, apesar dos inúmeros suspeitos 
investigados. O autor por trás do pseudônimo Zéfiro só seria revelado em 1991: o escriturário aposentado Alcides Caminha. No caso das editoras comerciais que tentavam produzir quadrinhos de cunho vagamente erótico, o anonimato não era uma opção. Editoras como Edrel, Grafipar, M\&C e GEP sofreram com a censura, apreensão de revistas e proibição de títulos, processo que, a longo prazo, acabou por minar a viabilidade comercial dessas publicações. É interessante destacar que, ao contrário da abordagem explícita dos catecismos, os títulos publicados por essas editoras eram bastante pudicos, com publicações de humor (Garotas \& Piadas), aventura (O Samurai, Estórias Adulta, Neuros) e terror (O Lobisomem, A Múmia, Estórias Negras) que utilizavam o erotismo apenas como elemento incidental para atrair mais público. Isso não impedia que a ação direta dos censores, que concebiam qualquer alusão ao sexo como um foco de subversão. Para a censura, o sexo era um questão de segurança nacional.

\section{CARLLS ZÉFIRO}
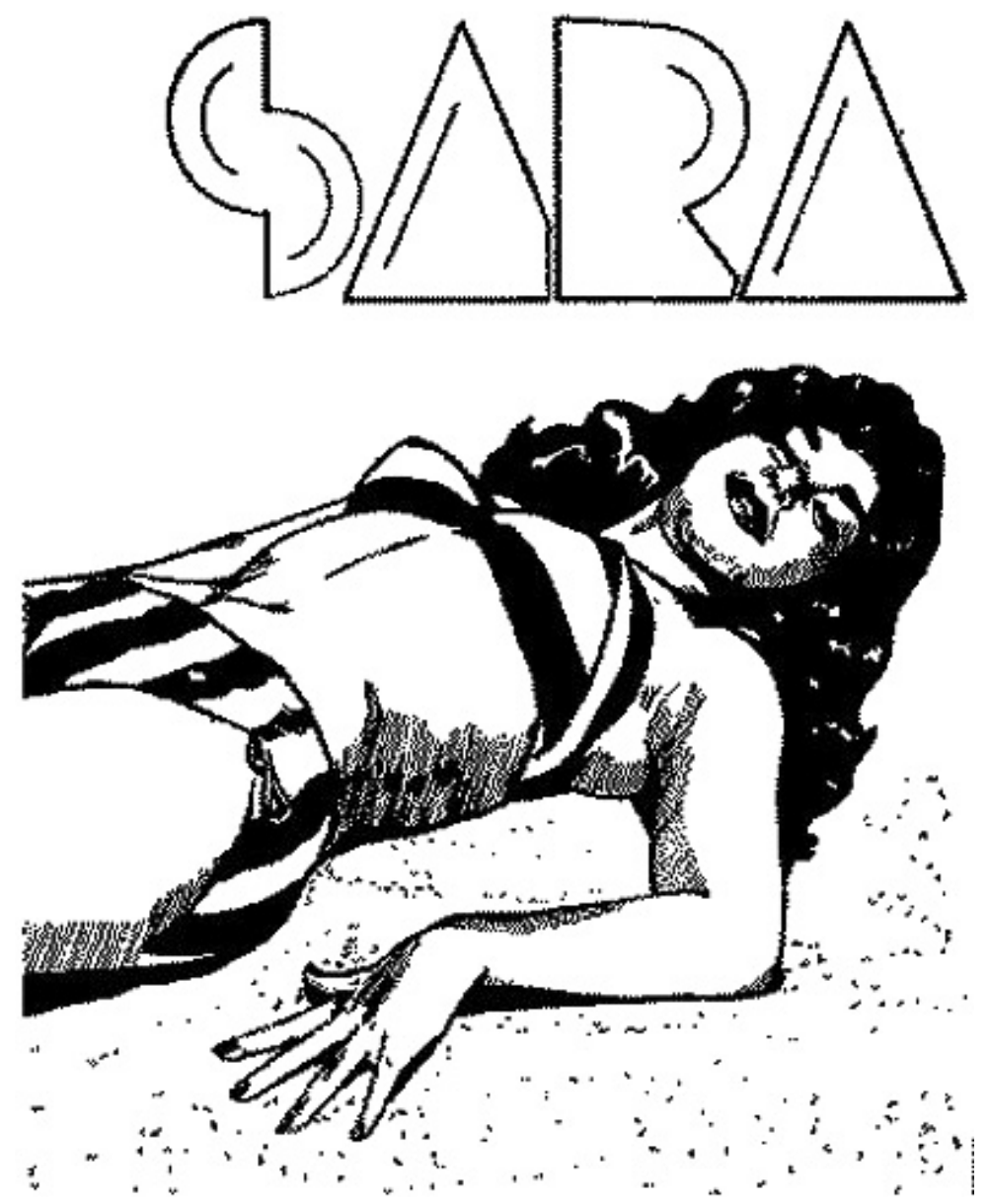

Figura 26 - Catecismo de Carlos Zéfiro 
A censura política nunca foi oficialmente admitida pelo regime. Existia, inclusive, uma preocupação clara por parte da censura em vetar qualquer menção a sua existência (1999, p.63). Decorre daí o expediente utilizados por alguns jornais de substituir os trechos excluídos por receitas de bolos ou poemas, uma forma velada de transmitir ao leitor os cortes efetuados. A ocultação do processo repressivo da censura também desempenhava um papel importante dentro da estratégia política do regime, conforme esclarece Aquino:

O Estado autoritário brasileiro pós-64 na mesma medida em que deseja um corpo social harmônico, escamoteando as diferenciações entre as camadas da sociedade e, particularmente, os conflitos derivados de posturas antagônicas, almeja também e, por isso, precisa ocultar divergências entre classes sociais, homogeneizando a diversidade e escondendo a dominação. Nestes termos, é relativamente fácil compreender a atuação censória impedindo a divulgação da existência dessas fraturas expostas no corpo social (AQUINO, p. 149-150).

A censura moral, por outro lado, sempre foi uma prática conduzida às claras (KUCINSKI, 2003, p.79). No final de 1969, a polêmica entrevista com Leila Diniz, veiculada no jornal O Pasquim (Figura 27), despertou reações negativas pela forma franca como a atriz abordou sua vida sexual. Além disso, os palavrões não foram cortados da edição final, como era prática comum, sendo substituídos por símbolos gráficos que, pelo contexto das frases, podiam ser facilmente decodificados. A reação da censura veio com o decreto-lei 1077 de janeiro de 1970, apelidado pela imprensa de "Decreto Leila Diniz", que disciplinava "publicações e exteriorizações contrárias à moral e aos bons costumes". Conforme Aquino, o decreto "promove uma relação entre os atentados à moral e um eventual plano subversivo com os decorrentes riscos à segurança nacional" (1999, p.64). O decreto também institui a censura prévia, formulada nos seus dois primeiros artigos:

Art. $1^{\circ}$ - Não serão toleradas as publicações e exteriorizações contrárias à moral e aos bons costumes, qualquer que sejam os meios de comunicação.

Art. $2^{\circ}$ - Caberá ao Ministério da Justiça, através do Departamento de Polícia Federal, verificar, quando julgar necessário, antes da 
divulgação de livros e periódicos, a existência de matéria infringente da proibição enunciada no artigo anterior.
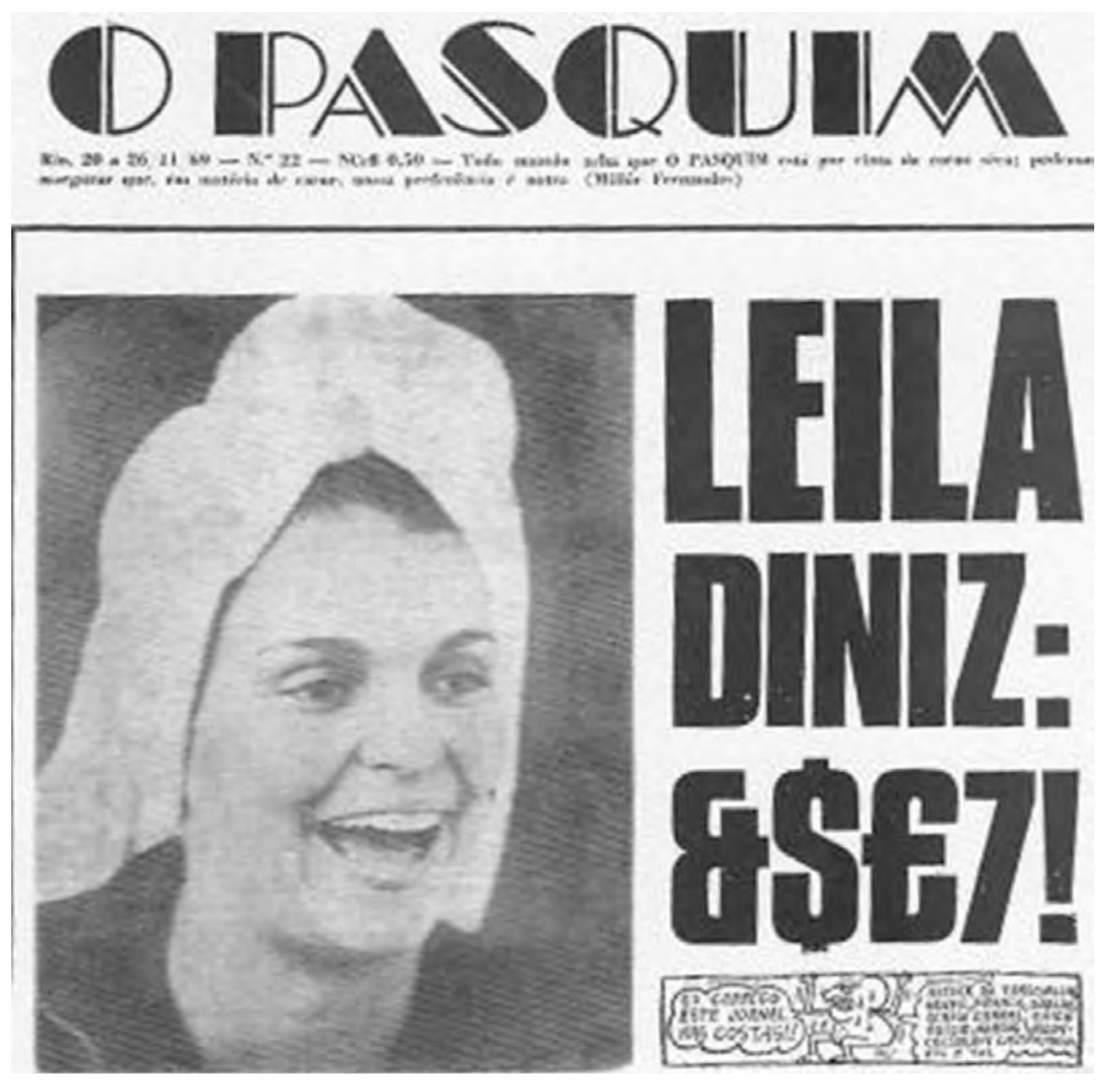

Figura 27 - O pasquim n²7, 1969

A política do regime e dos órgãos de repressão oficial identificava qualquer movimento que apontasse para uma maior liberação sexual como parte do projeto do comunismo internacional para minar as instituições tradicionais: família, casamento, religião, etc. Muito foi dito sobre o absurdo dessa proposição. Na edição 34 de $\mathbf{O}$ Pasquim, por exemplo, o editorial (não assinado, mas provavelmente de autoria de Millôr Fernandes) ironicamente lembrava que nos países da "cortina de ferro" a pornografia e o erotismo eram combatidos pelo Estado. Segundo Aquino, a relação entre sexo e segurança nacional tem uma raiz anterior ao próprio Regime Militar: 
Em 1949, foi fundada a Escola Superior de Guerra (ESG), um organismo que, por meio da promoção de cursos, palestras e conferências, formava militares e mesmo civis, afinados com as concepções assumidas pelas Forças Armadas Brasileiras. Estas, logo após a Segunda Guerra Mundial, foram influenciadas pela participação no evento, por curtas permanências de alguns oficiais nos Estados Unidos e pela filosofia desenvolvida naquele país nos anos iniciais da Guerra Fria. Dessas concepções, se origina a chamada Doutrina de Segurança Nacional que possui duas versões: no caso das nações economicamente mais avançadas, identifica o inimigo no comunismo externo, representado pelos países do Leste europeu; e no caso das nações menos desenvolvidas, o inimigo está alojado internamente, por intermédio da subversão à ordem visando sempre corroer os ideais democráticos e instaurar o socialismo (AQUINO, 1999, p.57).

Entre os editores de quadrinhos "eróticos" nacionais em atividade no período da ditadura militar, apenas Miguel Penteado, da editora GEP, poderia ser identificado como militante de esquerda. Não por acaso, sua primeira editora chama-se Outubro, em alusão à revolução bolchevique. Mesmo assim, é altamente improvável que a linha editorial de suas revistas utilizasse o erotismo como ferramenta para disseminação de uma agenda do comunismo internacional. Os demais editores, como Minami Keize da Edrel, Claudio Seto da Grafipar ou Octacílio Costa D’Assumpção Barros (Ota) da Vecchi, não tinham inclinações políticas claras. Na verdade, esses editores eram apenas empreendedores eficientes, que identificaram no mercado uma demanda a ser explorada. Desse período datam produções marcantes do quadrinho brasileiro, como o ciclo de histórias de terror conduzido pelos artistas Julio Shimamoto, Eugenio Colonesse, Flavio Colin, entre outros (SANTOS, 2011, p.66; OLIVEIRA, MOYA, 1977, p.231).

No campo da exploração de narrativas eróticas, publicadas pela Edrel e depois pela Grafipar, identificamos ainda uma interessante apropriação dos quadrinhos de vanguarda europeus e do mangá adulto, que pode ser encontrada de forma mais consistente na obra de Claudio Seto. Embora o autor trabalhasse num ritmo de produção massacrante, que muitas vezes prejudicava o produto final, Seto conseguiu construir algumas peças emblemáticas do quadrinho nacional do período, como Flores Manchadas de Sangue (1971) e O Sósia (1970), histórias curtas que apresentam uma diagramação experimental, com violência gráfica extrema (Figura 28) e uma noção muito particular de erotismo (Figura 29). Conforme Gonçalo Junior, 
durante a década de 1970 as narrativas de Seto eram bastante influenciadas pelo existencialismo de Jean-Paul Sartre e pela psicanálise (2010, p.186). O existencialismo se reflete em muitas de suas histórias de abordagem do cotidiano, onde desfilam jovens alienados lutando contra o vazio da existência. A psicanálise, por sua vez, sutilmente permeava sua narrativas eróticas e de terror, cujas personagens frequentemente são motivadas por impulsos profundos, primitivos e não devidamente esclarecidos. Gonçalo destaca ainda que Seto era leitor regular de revistas importadas, o que explicaria em parte sua aproximação com a abordagem psicanalítica do erotismo dos quadrinhos europeus.

O artista [Seto] parecia estar em sintonia também com o criador de Valentina, Guido Crepax (1931-2003), ainda inédito no Brasil na época, ao trazer os conceitos de Freud e o erotismo para os quadrinhos brasileiros. Sua ideia era consagrar a linha de pensamento do pai da psicanálise como pano de fundo para explicar as dúvidas existenciais dos personagens ou tratar de relacionamentos, sexo e até terror, de cunho psicológico também (GONÇALO JUNIOR, 2010, p.186).

Um problema frequente que se impõe quando da análise das histórias em quadrinhos eróticas do período diz respeito à autocensura a que se submetia toda a cadeia de produção. $\mathrm{O}$ editor sempre andava numa corda bamba, tentando equilibrar uma abordagem que pudesse ser reconhecida como erótica pelo leitor, com o conservadorismo que a censura exigia. Se um dos quadrinhistas apresentasse um produto mais ousado, seria cortado para evitar apreensão. Os artistas, por sua vez, evitavam se afastar da linha editorial, já que que não seriam pagos caso a história fosse rejeitada. Esse clima de paranoia era potencializado pela atuação da censura, bem mais incisiva contra os editores de quadrinhos. Enquanto as publicações de orientação erótica das grandes editoras, como as revistas masculinas Status, Ele \& Ela e Revista do Homem (atual Playboy), conseguiam articular uma trégua negociada com os órgãos de repressão, baseada principalmente no retoque de fotos para disfarçar mamilos e pelos pubianos (o nu frontal só seria liberado em 1980), os editores de quadrinhos tinham suas publicações completamente censuradas e muitas vezes eram impedidos de lançar novos títulos. Conforme a Portaria 219, de 16 de abril de 1973, todas as publicações "prejudiciais à moral e aos bons costumes" só 
poderiam circular após registro no Departamento da Polícia Federal. Caso não existisse uma pressão sobre os órgãos da censura, os novos títulos não eram liberados. Obviamente as grandes editoras (Abril, Bloch, Editora 3), que não se dedicavam unicamente a publicações eróticas, detinham um maior poder simbólico para barganha e conseguiam lançar seus títulos, enquanto os projetos das editoras de quadrinhos, cujos editores eram identificados como pornógrafos, se perdiam na burocracia.
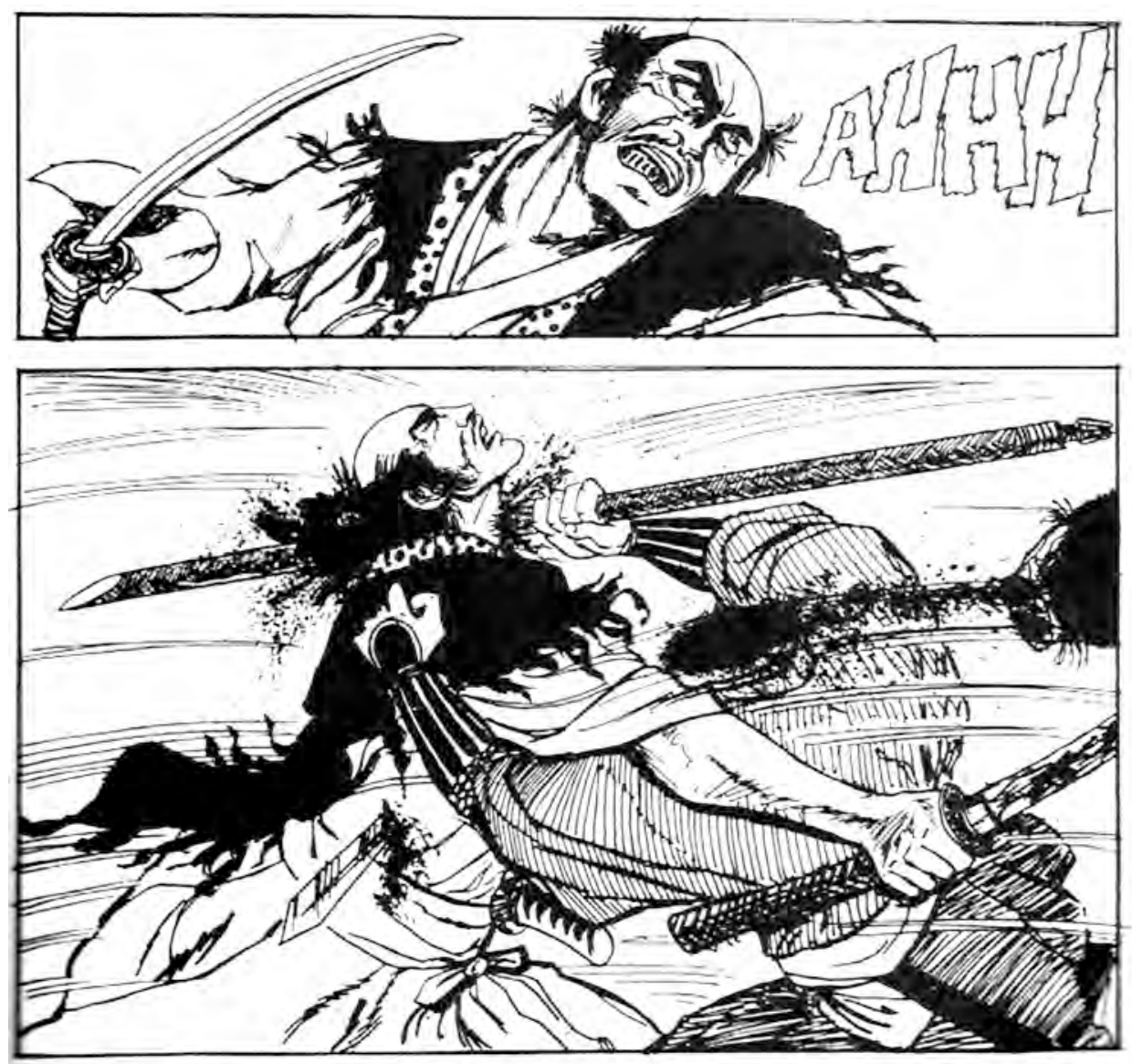

Figura 28 - O Sósia, de Claudio Seto

Assim, no caso dos quadrinhos eróticos, o desempenho dos órgãos de repressão corrobora a tese da arbitrariedade da censura, defendida por Aquino (1999). Em sua pesquisa, Aquino comparou a censura em dois jornais, Movimento e $\mathbf{O}$ Estado de São Paulo, identificando uma repressão mais intensa ao jornal alternativo, mesmo quando ambos tratavam do mesmo tema/acontecimento. Sandra Reimão também percebe essa atuação diferenciada no caso da peça $O$ berço dos heróis (1963), de Dias Gomes, cuja encenação foi proibida em 1965, ao mesmo tempo em 
que o livro se tornava sucesso de vendas. Dez anos depois, o enredo foi adaptado para a telenovela Roque Santeiro, novamente proibida (2011, p.34). Por esses indícios, é possível perceber que a censura atuava de formas diferentes, pautando-se em função da mídia e do impacto estimado junto ao público. Dessa forma, os quadrinhos, sempre associados à infância, sofriam uma atuação censória mais intensa que nas publicações de nus fotográficos, supostamente destinados a adultos.
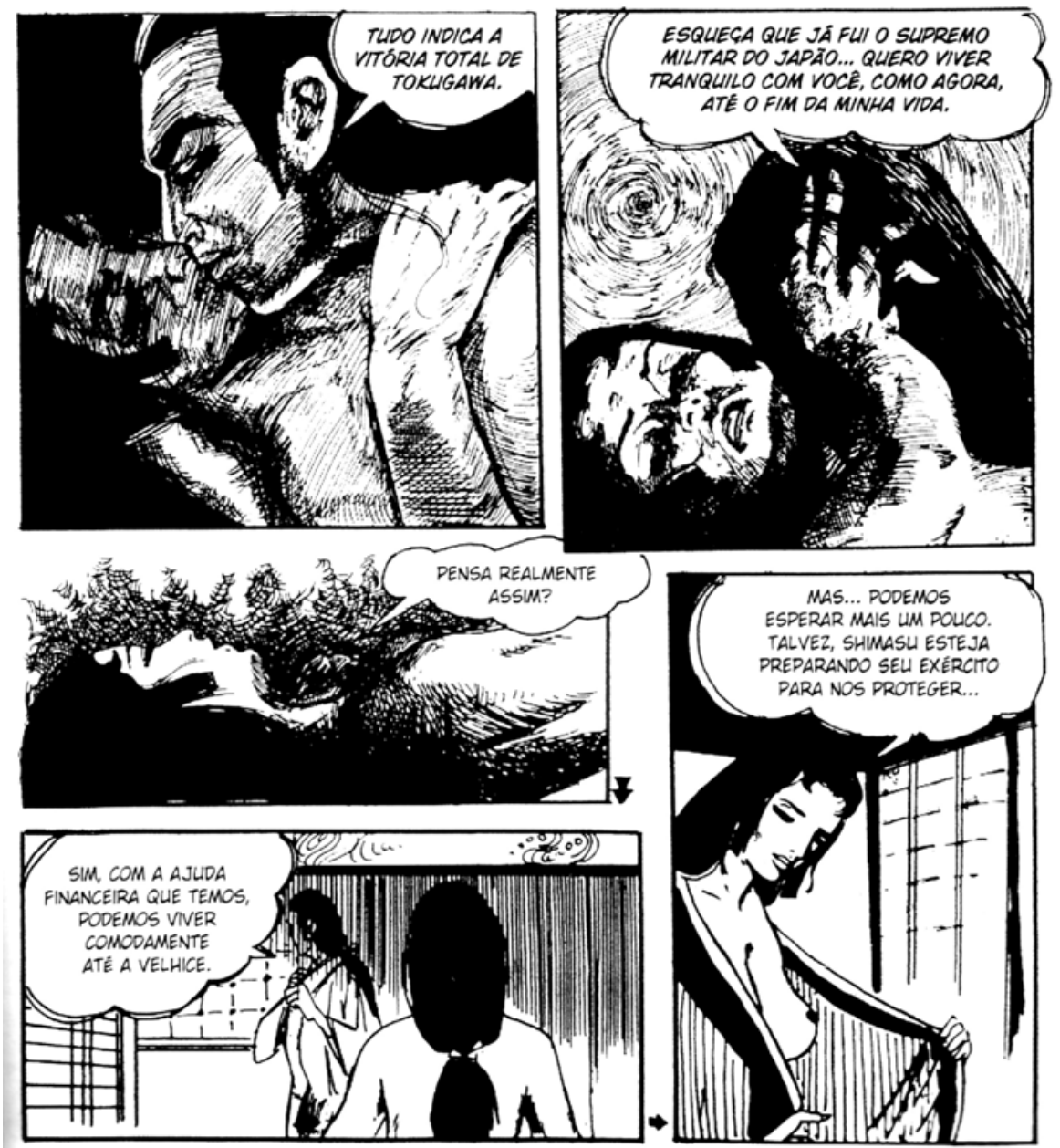

Figura 29 - O Sósia, de Claudio Seto

Embora a maior parte dos quadrinhos de orientação erótica publicados pelas editoras Edrel e Grafipar apresente um nível de qualidade contestável, com roteiros banais e desenhos pouco inspirados, em algumas passagens é possível perceber um movimento que aproxima o estilo de produção nacional da vanguarda dos quadrinhos que despontava no resto do mundo. Nos raros momentos em que conseguiam driblar a censura, as obras de criadores como Fernando Ikoma, Marco Araújo Liesenfeld e Claúdio Seto, por exemplo, apresentam um nível de inventividade e excelência 
gráfica comparável ao de artistas europeus. Nesse sentido, é sempre interessante especular acerca do tipo de quadrinho que esses autores poderiam ter produzido, caso tivessem se deparado com um ambiente culturalmente favorável. No caso específico do mercado editorial brasileiro, apenas com a abertura política iniciada durante a década de 1980 foram criadas condições favoráveis ao desenvolvimento de um modelo de produção quadrinhística que incorporasse as inovações que se faziam presentes no contexto europeu, japonês e norte-americano desde o final da década de 1960. Contudo, o percurso para essa nova fase da produção brasileira, em grande medida articulado nas revistas da Circo Editorial, afasta-se do contexto das editoras de quadrinhos eróticos em direção ao espaço de experimentação encontrado na imprensa alternativa. 


\title{
3.3 Da imprensa alternativa aos quadrinhos da Circo Editorial
}

A imprensa alternativa é uma modalidade de mídia que subverte os princípios e procedimentos do jornalismo tradicional, particularmente a chamada "ideologia da objetividade", em função de um posicionamento filosófico/ideológico particular. Muitas vezes tocados por "empreendedores" individuais, que acumulam diversas funções da cadeia produtiva, esses periódicos se caracterizam como um modelo de produção contra-hegemônico, um espaço para ideias e temas excluídos da imprensa tradicional. Segundo Henrique Magalhães, durante a década de 1960, a imprensa alternativa caracterizou-se como um fenômeno comum a vários países do mundo. "Na América Latina, ela teve um perfil de resistência política, impulsionada pela realidade autoritária que se impunha ao continente" (2003, p.11). No caso específico da realidade brasileira, essa modalidade de jornalismo radical possui uma tradição de "surtos esporádicos", como os pasquins dos tempos da Regência (cujo auge deu-se em 1830) e os jornais anarquistas operários (1880-1920) (KUCINSKI, 2003, p.21), mas adquire contornos nítidos após o golpe militar.

\begin{abstract}
Durante os quinze anos de ditadura militar no Brasil, entre 1964 e 1980, nasceram e morreram cerca de 150 periódicos que tinham como traço comum a oposição ao intransigente ao regime militar. Ficariam conhecidos como imprensa alternativa ou imprensa nanica. A palavra nanica, inspirada no formato tablóide adotado pela maioria dos jornais alternativos, foi disseminada principalmente por publicitários, num curto período em que eles se deixaram cativar por esses jornais. Enfatizava uma pequenez atribuída pelo sistema a partir de sua escala de valores e não dos valores intrínsecos à imprensa alternativa. Ainda sugeria imaturidade e promessas de tratamento paternal. Já o radical de alternativa contém quatro dos significados essenciais dessa imprensa: o de algo que não está ligado a políticas dominantes; o de uma opção entre duas coisas reciprocamente excludentes; o de única saída para uma situação difícil e, finalmente, o do desejo de gerações dos anos de 1960 e 1970, de protagonizar as transformações sociais que pregavam (KUCINSKI, 2003, p.13).
\end{abstract}

Ao contrário dos jornais underground norte-americanos que desempenharam uma função central no fortalecimento do movimento do comix, a imprensa alternativa no Brasil não era um espaço que privilegiasse os quadrinhos. Por outro lado, havia 
uma forte demanda por humor gráfico (cartuns) e pelos gêneros pictográficos do jornalismo (charge, caricatura). O sucesso do jornal O Pasquim, por exemplo, está diretamente atrelado à atuação do grupo de talentosos criadores gráficos que reunia: Henfil, Ziraldo, Jaguar, Claudius e Millôr Fernandes. Essa maior participação dos gêneros pictográficos do jornalismo pode ser facilmente explicada quando se considera "a contingência do combate político-ideológico à ditadura" encampado pela imprensa alternativa (KUCINSKI, 2003, p.16). Frente a esse embate muito concreto e iminente, o espaço para a experimentação formal e desenvolvimento das histórias em quadrinhos propriamente ditas ficava bastante limitado. Mesmo assim, algumas publicações alternativas inspiradas nos movimentos contraculturais da década de 1960 ensaiaram uma aproximação mais consistente com os quadrinhos.

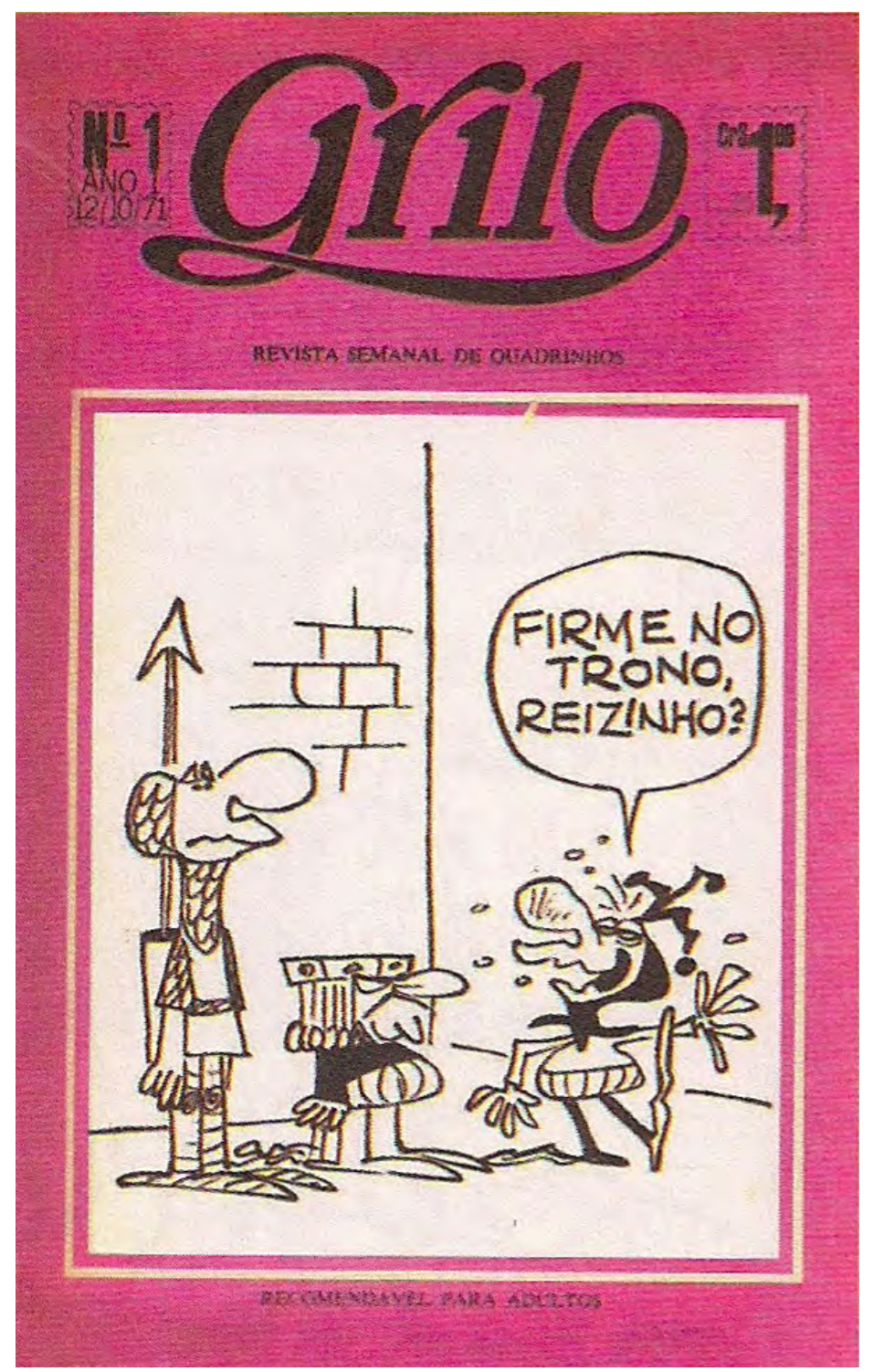

Figura 30 - Revista Grilo ${ }^{\circ} 1$ 
Conforme a classificação proposta por Kucinski, existiram basicamente duas classes de jornais alternativos no Brasil, ambas igualmente engajadas na luta contra o regime: os políticos, cujas raízes remetem aos "ideais de valorização do nacional e do popular dos anos de 1950 e no marxismo vulgarizado dos meios estudantis nos anos de 1960" (KUCINSKI, 2003, p.14); e os inspirados "nos movimentos de contracultura norte-americana e, através deles, no orientalismo, no anarquismo e no existencialismo de Jean-Paul Sartre” (KUCINSKI, 2003, p.15). Enquanto os jornais políticos se preocupavam em seguir uma orientação política rígida (maoísmo, trotskismo, etc), muitas vezes funcionado como veículos oficiais de partidos e organizações políticas clandestinas, as publicações ligadas à contracultura estavam menos preocupadas com os discursos ideológicos, constituindo-se com um espaço voltado à experimentação, “à crítica de costumes e à ruptura cultural” (KUCINSKI, 2003, p.15).

É importante destacar que a penetração da contracultura norte-americana na sociedade brasileira foi um processo que aconteceu de forma muito gradual e com um atraso de alguns anos. Na imprensa tradicional, por exemplo, a contracultura era uma pauta pouco abordada. Uma das raras exceções era a revista Realidade, bastante sintonizada com essas novas tendências, como atesta a reportagem em profundidade acerca do movimento hippie, publicada na edição de fevereiro de 1968. Influenciada pelo new journalism, movimento norte-americano de renovação da prática da reportagem encabeçado por Tom Wolf, Norman Mailer e Gay Talese, Realidade se destacou durante sua primeira fase (1966-1968) pelas várias inovações formais que incorporavam às técnicas jornalísticas elementos da literatura, como a narrativa em primeira pessoa, descrições elaboradas, fluxo de consciência e diálogos precisos. A linha editorial da revista privilegiava um modelo de jornalismo aprofundado e de investigação, que resultou em várias reportagens antológicas, como o dossiê sobre a sexualidade da mulher brasileira publicado na edição 29 de dezembro de 1966 (metade da tiragem foi apreendida por ordem do juizado de menores). Conforme Goncalo Junior,

Desde o começo, [Realidade] falou abertamente em revolução sexual, virgindade e mãe solteira. Destacou também o casamento de padres, o divórcio e o sexo antes e fora do casamento, além do homossexualismo. Nos dois primeiros anos, "Realidade" fez jus ao 
seu título, com atualidades polêmicas como a Guerra do Vietnã, a pílula anticoncepcional e o amor livre. Na música, mostrou a revolução promovida pelos grupos britânicos The Beatles e Rolling Stones, além do americano Bob Dylan (GONÇALO JUNIOR, 2012, p.37).

No final do ano de 1968, após uma disputa interna entre a redação e Roberto Civita, boa parte da equipe abandonou a revista, incluindo o editor Paulo Patarra. Entre os dissidentes da Realidade estavam os jornalistas Sérgio de Souza e José Carlos Marão, que posteriormente editariam Grilo, revista nacional responsável por introduzir os quadrinhos do underground norte-americano e da vanguarda europeia no mercado brasileiro. Publicada a partir de 1971 pela Editora A\&C, Grilo foi uma das poucas publicações alternativas unicamente dedicada aos quadrinhos. A revista italiana Linus era sua principal inspiração mas, estranhamente, seu formato tabloide e a periodicidade semanal remetiam diretamente aos suplementos de jornais que fizeram sucesso no mercado brasileiro nas décadas anteriores (a partir da edição 25 a revista assume um formato semelhante ao americano).

Nas primeiras edições, Grilo apresenta uma linha editorial mais branda, publicando os quadrinhos políticos de Jules Feiffer e séries de humor sofisticado, como Charlie Brown (Peanuts), de Charles M. Schulz, Reizinho (Little King), de Otto Soglow e Pogo, de Walt Kelly. Mesmo assim, a revista apresentava toques bastante subversivos já na sua edição de estreia (Figura 30), que estampava o bobo da corte perguntando: “Firme no trono, Reizinho?". Esse tipo provocação era típico do jogo de desvios de sentidos perpetrados pelos veículos de comunicação alternativos contra a censura, já que esse cartum inocente também pode ser lido como uma crítica ao Presidente Emílio Garrastazu Médici. A edição número 6 de Grilo é marcada pela estreia da série Valentina, de Guido Crepax, em sua primeira publicação no país. Conforme Gonçalo Junior, foram necessários alguns malabarismos por parte do editor José Carlos Marão para driblar a censura e publicar essa série de forte conteúdo erótico, o que exigiu uma "rigorosa seleção das histórias em que a nudez e o sexo não apareciam de modo explícito ou que tivessem abordagem política mais direta" (GONÇALO JUNIOR, 2012, p.134). Na edição número 26 (maio de 1972) a história de quatro páginas intitulada Whiteman marca o início da publicação da obra de Robert Crumb no Brasil. Assim como aconteceu com a série Valentina, a participação de Crumb na revista Grilo também se mostrou problemática. 
Robert Crumb foi um alvo implacável da censura durante todo o tempo em que saiu na revista. A pressão contra a nudez dos personagens do artista, por exemplo, levou a que boa parte de suas histórias publicadas na revista fosse mutilada e houve até casos de cenas retiradas. Do número 26 ao 30, o veto do artista se deu de duas formas: na cuidadosa seleção das histórias por Ferraz, com a exclusão das que tivessem alguma conotação sexual; e pelo abrandamento dos diálogos e dos palavrões. Com o estrondoso sucesso do desenhista nas páginas da revista, no entanto, tornou-se imprescindível publicá-lo em todos os números. Como havia necessidade de material inédito, surgiu um problema porque nem sempre o autor desvinculava crítica social, política e de comportamento aos tabus sexuais da América (GONÇALO JUNIOR, 2012, p.216-217).

Na edição número 32 acontece um ato censório ainda mais concreto: em dois quadros de uma história do Mr. Natural o pênis da personagem Flakey Foont é escondido por tarjas com propagandas da Editora A\&C (Figura 31): na página 36 a primeira tarja recomenda que se "Leia o Jornalivro"; e na página 30 lê-se num balão o complemento "Nas Bancas" e logo abaixo "Cr 2". Esse mecanismo era duplamente subversivo, já que pouco amenizava o conteúdo "pornográfico" da cena (em nenhum dos casos é difícil imaginar do que se tratava a imagem) e ainda conseguia explicitar a atuação da censura. Esse embate constante com os órgãos de repressão finalmente levou à proibição da revista Grilo, que encerrou suas atividades no número 48.

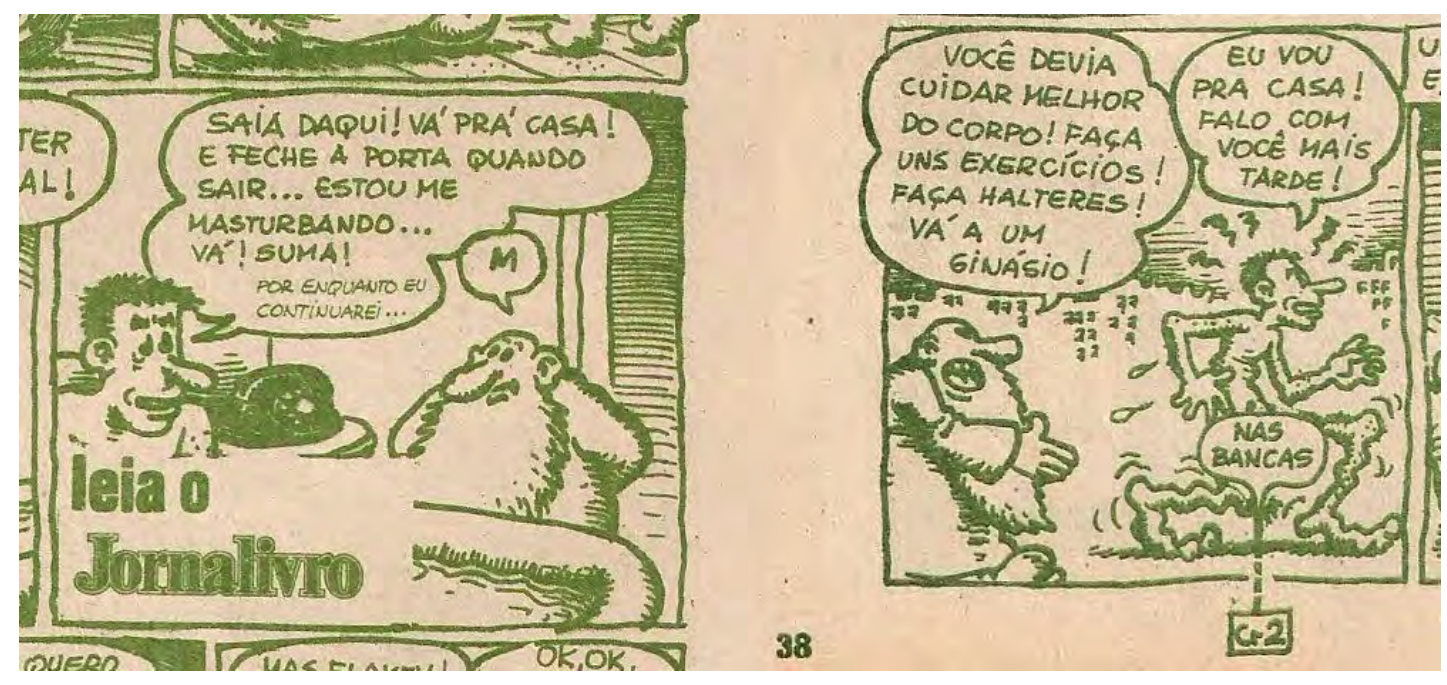

Figura 31 - Censura a Crumb na revista Grilo ${ }^{0} 32$ 


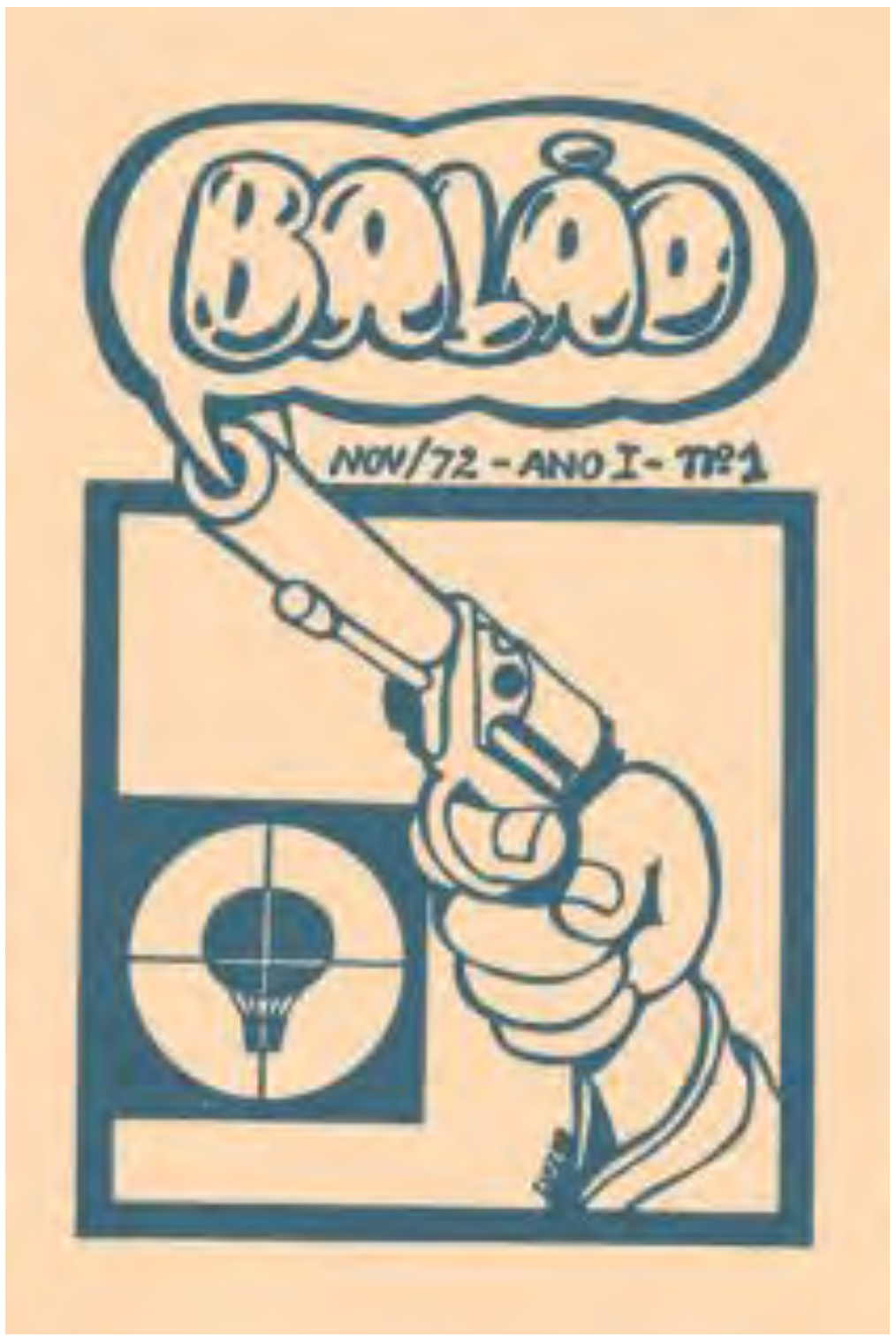

Figura 32 - Revista Balão ${ }^{\circ} 1$

A revista Grilo desempenhou um papel importante na divulgação das principais tendências das quadrinhos norte-americanos e europeus (publicando muitas histórias pirateadas, vale salientar), além de manter o leitor informado com colunas fixas sobre atualidades do mundo das histórias em quadrinhos e dos fanzines. Além disso, a seção de cartas era um espaço bastante interessante e subversivo, onde os editores utilizavam-se de estratagemas diversos para mostrar ao leitor as pressões da censura sobre o andamento da publicação. Contudo, nenhuma das edições apresentou artistas nacionais. Na mesma seção de cartas, os editores argumentavam que não existia no país quadrinhistas que produzissem um trabalho que se enquadrasse na linha editorial da revista. Outras revistas do período seriam responsáveis por 
introduzir autores nacionais no universo das publicações alternativas, conforme destaca Kucinski:

Entre 1971 e 1972, surge uma quinta fase de jornais, como Grilo e Balão, que se caracterizavam pelo humor pesado, às vezes escatológico, e pelo experimentalismo em linguagem. Ambos, influenciados pelo cartunista americano Robert Crumb e pelo europeu Wolinski. Grilo reproduz diretamente cartoons estrangeiros, inclusive os mais tradicionais, de Charles Shultz. Mas Balão expressa, ao contrário, um reação dos jovens contra a dominação estrangeira no mercado de cartoons e dá origem a uma explosão criativa de humor nacional por uma nova geração de cartunistas iniciantes, entre os quais Luis Gê, Laerte, Angeli e os irmãos Chico e Paulo Caruso. Cerca de setenta novos desenhistas passaram pelas dez edições de $O$ Balão. Por influência de Balão e Grilo surgiram novos "gibis", de crítica pesada aos costumes, autodenominados "udigrudi" (do inglês underground), entre os quais Patota, Vaca Amarela e Klik (KUCINSKI, 2003, p.34).

Embora tenha ganhado notoriedade pelo grupo de talentosos criadores que reunia, Balão foi uma revista de pouco impacto junto ao público. Na verdade, tratavase de um fanzine (Figura 32), feito artesanalmente e vendido de mão em mão, principalmente entre os alunos da Universidade de São Paulo. O jornal Versus, lançado em 1975, seria o responsável por divulgar esse mesmo grupo de autores para um público mais amplo (KUCINSKI, 2003, p.255). Embora não fosse uma publicação especialidade em quadrinhos, como Grilo e Balão, Versus privilegiava todo tipo de informação gráfica, publicando inclusive dois especiais de quadrinhos onde já é possível identificar um direcionamento para o estilo que Angeli e Luiz Gê (Luiz Geraldo Ferrari Martins) desenvolveriam na década posterior. Entre os funcionários do jornal Versus estava Toninho Mendes (Antônio de Souza Mendes Neto), que atuava como diagramador (past up) e assistente de arte. Durante a década de 1980, no contexto da abertura política, Toninho seria responsável por colocar nas bancas uma série de revistas icônicas que, livres das amarras da censura oficial, conseguiram trabalhar livremente as tendências dos quadrinhos alternativos, perpetrando diversas "inovações temáticas, narrativas e estéticas” (SANTOS, 2010, p.148). Essa renovação criativa dos quadrinhos nacionais, ocorrida durante a década de 1980, segue um padrão semelhante ao de outros países que sofreram com a 
censura de regimes ditatoriais. Na Espanha, por exemplo, ocorre uma grande transformação no mercado dos quadrinhos após a queda do ditador Francisco Franco Bahamonde, processo que se articula principalmente em torno das revistas underground El Víbora e Cairo (DANNER; MAZUR, 2014, p.161).

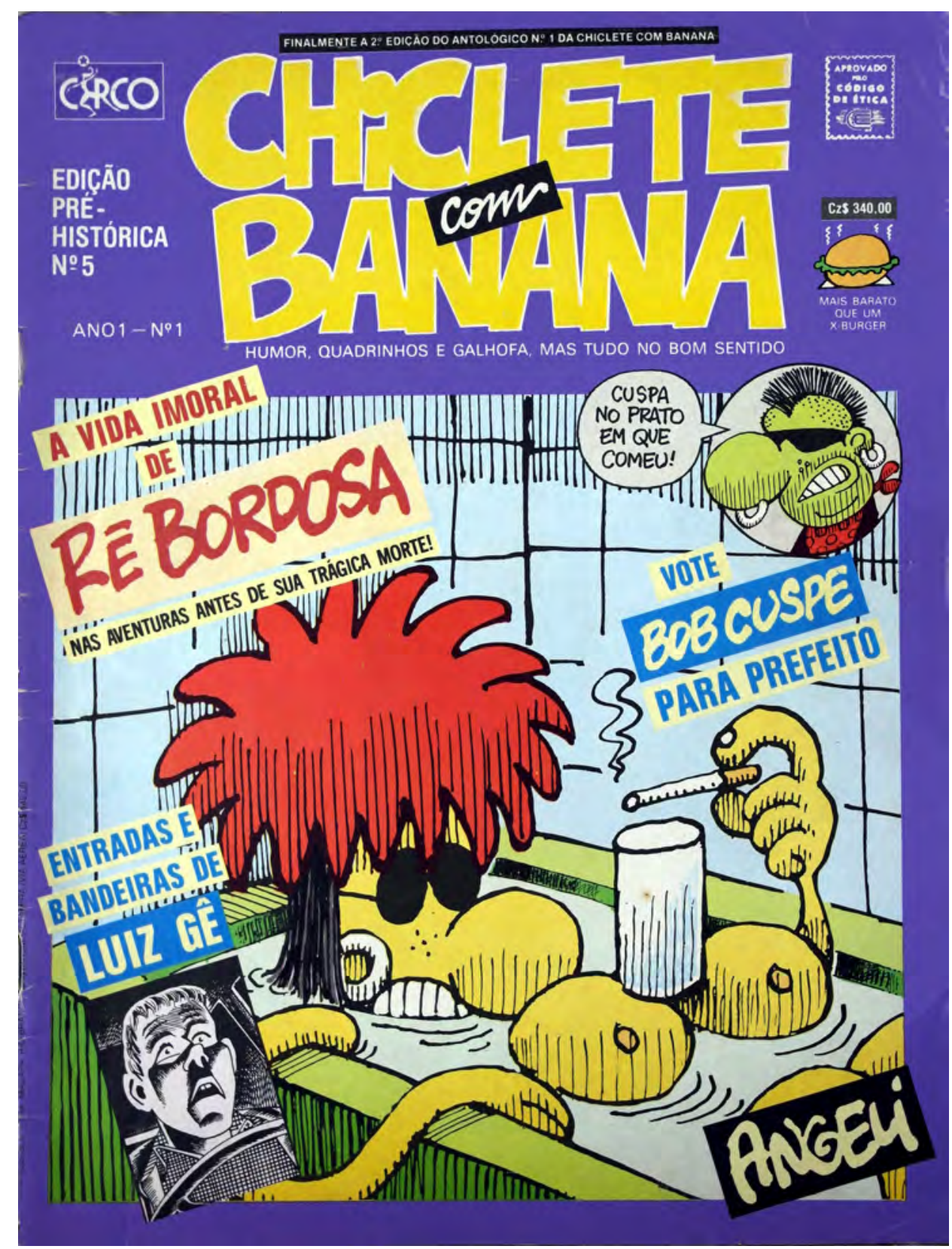

Figura 33 - Chiclete com Banana ${ }^{\circ} 1$

A primeira aventura de Toninho no mundo editorial acontece ainda em 1980, com a criação da Marco Zero. A editora não foi bem sucedida comercialmente e lançou apenas três títulos: A Confissão para o Rio Tietê, longo poema do próprio Toninho; Coisas da Negra Sarará, livro do poeta Roque de Souza com edição 
bancada pelo próprio autor; e Natureza Morta, que reunia charges de Chico Caruso para o Jornal do Brasil. Em 1984, Toninho criou a Circo Editorial, lançando os livros Chiclete com Banana, Bob Cuspe e Outros Inúteis, de Angeli, e Não Tenho Palavras, como novas charges de Chico Caruso. Segundo Ivan Finnotti, as duas publicações venderam muito bem em livrarias e o livro de Angeli chegou a ser impresso oito vezes, vendendo 30 mil exemplares no total (2014, p.23). Frente ao sucesso comercial de suas publicações, Toninho concebeu a ideia de lançar duas revistas, a Chiclete com Banana, que reuniria o trabalho de Angeli, e a Circo, que agregaria os autores Luiz Gê, Laerte, Glauco, Alcy e Paulo Caruso. Chiclete com Banana foi lançada primeiro, em outubro de 1985 (Figura 33). A revista mostrou-se um sucesso imediato, com vendagem de 28 mil exemplares na primeira edição. A edição 3 já vendia 40 mil; a partir da edição 11, o número se estabilizou em torno de 100 mil exemplares. Chiclete com Banana tinha periodicidade bimestral e, ao todo, foram publicados 24 números da série regular (1985 a 1990), 10 números da Série Tipinhos Inúteis (1991 a 1994), 3 números de The Best of Chiclete com Banana (1995), além de diversos especiais, como Rê Bordosa - A morte da porralouca (1987), Chiclete com Banana Remix (1988), Bob Cuspe - O nervo exposto (1988), Abaixo a direita! (1990) e Lovestórias. Conforme Vergueiro,

\begin{abstract}
As razões do sucesso da Chiclete com Banana podem estar em um tripé: o autor, os personagens e o momento político e social. Um autor forte, com um fiel público leitor. Um grupo de personagens que encontrava eco em camadas expressivas da juventude, sedentas de figuras que pudessem expressar seu descontentamento com o status, sua revolta em relação aos costumes e suas inquietações quanto ao presente e ao futuro. Um momento especialmente permeável a esse tipo de agitações, marcado por uma liberdade recentemente adquirida, que possibilitava audácias antes jamais imagináveis (VERGUEIRO, 2014, p. 54-55).
\end{abstract}

Em 1987, Toninho Mendes dá início à expansão da editora, com o lançamento da revista Circo (8 números). No ano seguinte são lançadas as revistas Geraldão, com as personagens do cartunista Glauco e Níquel Náusea, focada no trabalho de Fernando Gonsales. Em 1990, Laerte também ganha uma revista própria, a Piratas do Tietê, publicada até 1992 (14 números). Em 1993, lança uma nova revista de 
Laerte, Striptiras. Ao mesmo tempo, Toninho editava a Coleção Circo, uma série de livretos de quadrinhos ou charges publicados em parceria com a Editora Sampa.

O modus operanti do editor Toninho Mendes consistia em escolher artistas que já tivessem uma carreira consolidada dentro da grande imprensa para encabeçar as revistas. Entravam na equação também critérios subjetivos, como a relação de amizade que desenvolvia com diversos cartunistas. Toninho e Angeli, por exemplo, se conheciam desde a adolescência, quando ambos moravam no bairro Casa Verde, na periferia de São Paulo às margens do Rio Tietê. A fato da maior parte dos colaboradores da Circo Editorial possuírem raízes anteriores como criadores gráficos da imprensa tradicional, em grande medida explica a orientação fundamentalmente humorística de suas publicações. Obviamente existiam grandes diferenças entre o estilo de humor conduzido em cada revista: Chiclete como Banana era mais política; Piratas do Tietê mais experimental; e Geraldão mais nonsense. Contudo, todas tinham em comum o humor ácido e a crítica social e de costumes. A única exceção era a revista Circo que, apesar de também publicar histórias humorísticas, era fundamentalmente dedicada à experimentação.

Essa diferença na concepção e na linha editorial da revista Circo aconteceu principalmente devido à influência de seu editor de arte, Luiz Gê. No expediente da revista é possível perceber que Toninho Mendes ocupava oficialmente a posição de editor. Na prática, Luiz Gê era o principal responsável pelo andamento da revista. Em suas 8 edições, Circo mostrou-se uma das experiências editoriais mais originais conduzidas no mercado brasileiro. Histórias antológicas de Laerte (como Piratas do Tietê - O Poeta, Palhaços Mudos, Fadas e Bruxas e A insustentável Leveza do Ser) e Luis Gê (Perdidos no Espaço, Futboil, Uma história de Amor) apontavam para um modelo de experimentação cuja plasticidade é equiparável, senão superior, aos trabalhos mais proeminentes da vanguarda norte-americana e europeia.

Em 1995 a Circo editorial encerra suas atividades. Durante todo o período em que esteve em atividade a editora sofreu com "dificuldades internas para gestão da editora, a inflação galopante, o atraso na periodicidade e o consequente recebimento das vendas efetuadas [...]" (VERGUEIRO, 2014, p.55). A inflação desenfreada é provavelmente o problema que mais minou o equilíbrio financeiro da editora. Devido à periodicidade bimestral, a cada número que enviava para as bancas Toninho precisava fazer uma previsão do preço de capa que compensasse a desvalorização. Apesar das boas vendas, muitas vezes o valor recebido não era suficiente para bancar 
a próxima edição. Segundo Ivan Finnotti, a falta de traquejo de Toninho Mendes também contribuía bastante para o descontrole financeiro da editora (2014, p.26).

A venda de espaços publicitários na revista também era deficiente, principalmente se considerarmos a tiragem e o público alvo que a publicação atingia. A maior parte de anúncios era de produtos da própria Circo Editorial, como revistas, livros e camisetas das personagens. Além disso, esporadicamente eram anunciados livros da editora Brasiliense, vendidos por reembolso postal. Em todos os números da Chiclete com Banana só foram veiculadas duas publicidades de destaque: Jeans Levi's, na edição 12; e uma propaganda da FM 97.7, na edição 15. Em certo sentido, as deficiências de Toninho na administração da empresa reforçam seu papel como editor talentoso e profundamente sintonizado com as demandas do público, já que, frente ao contexto de instabilidade econômica e aos problemas internos na administração da editora, a qualidade de suas revistas permitiram que a Circo Editorial se mantivesse em atividade por 10 anos. 


\section{CAPÍTULO IV - A ESTRUTURA DA AUTOBIOGRAFIA EM ANGELI}

\subsection{Angeli em crise}

Arnaldo Angeli Filho estreou na imprensa bastante precocemente, publicando aos 14 anos um desenho na revista Senhor, em 1970. Seguindo a tradição dos humoristas gráficos brasileiros que, normalmente, assinam suas produções com apenas um nome, em seus primeiros trabalhos já se identifica apenas como Angeli. Nos anos seguintes, o autor colaborou com diversos fanzines (Balão) e revistas alternativas (Versus, Movimento), até que em 1973 inicia sua participação como chargista e cartunista na Folha de S. Paulo, função que ocupa até o presente. Conforme Vergueiro (2014, p.36), a carreira de Angeli se consolida em definitivo na virada dos anos 1970 para os 1980. Esse período também marca uma transição, na qual o autor se afasta gradativamente dos cartuns políticos em direção às tiras diárias. Em entrevista concedida em 2012 para a revista Brasileiros, Angeli relembra o período:

Eu tinha verdadeira adoração pelo Crumb e ele foi decisivo para me convencer de que eu teria de fazer algo autoral, falar da minha vida, das coisas que eu gostava, das raivas que eu tinha, do meu desprezo à burguesia, mas eu estava fazendo charge política na Folha em uma época que não se podia apontar o dedo ou desenhar generais. Foi, então, que falei que queria sair da charge e comecei a produzir tiras. Só havia tiras americanas na Folha e os embriões da Chiclete com Banana surgiram nesse novo espaço que defendi.

Assim, em 15 de março de 1981 é iniciada a publicação da série Chiclete com Banana na Folha de S. Paulo, onde o autor introduz suas primeiras personagens fixas: Meiaoito, Ritapop, Tudoblu, AI-5 e Moçamba. Nessa fase inicial da série, Chiclete com Banana era publicada aos domingos, na seção Vira-Lata do caderno Folhetim. Essa seção, que ocupava apenas uma página, era editada pelo próprio Angeli, que acabou sendo o responsável por introduzir criadores como Laerte e Glauco na imprensa diária. A identidade visual da Vira-Lata era bastante acentuada, remetendo mais a produções da imprensa alternativa do que propriamente a um jornal 
diário. Nesse contexto menos rígido de editoração gráfica, a série Chiclete com Banana variava muito de tamanho, mas sempre seguindo uma estrutura semelhante ao modelo de página inteira (Figura 34), utilizada por cartunistas como Henfil, por exemplo. A publicação da série segue na seção Vira-Lata por quase dois anos, até que em 6 de Janeiro de 1983 Chiclete com Banana se transforma em uma tira diária, publicada no caderno Ilustrada (Figura 35).

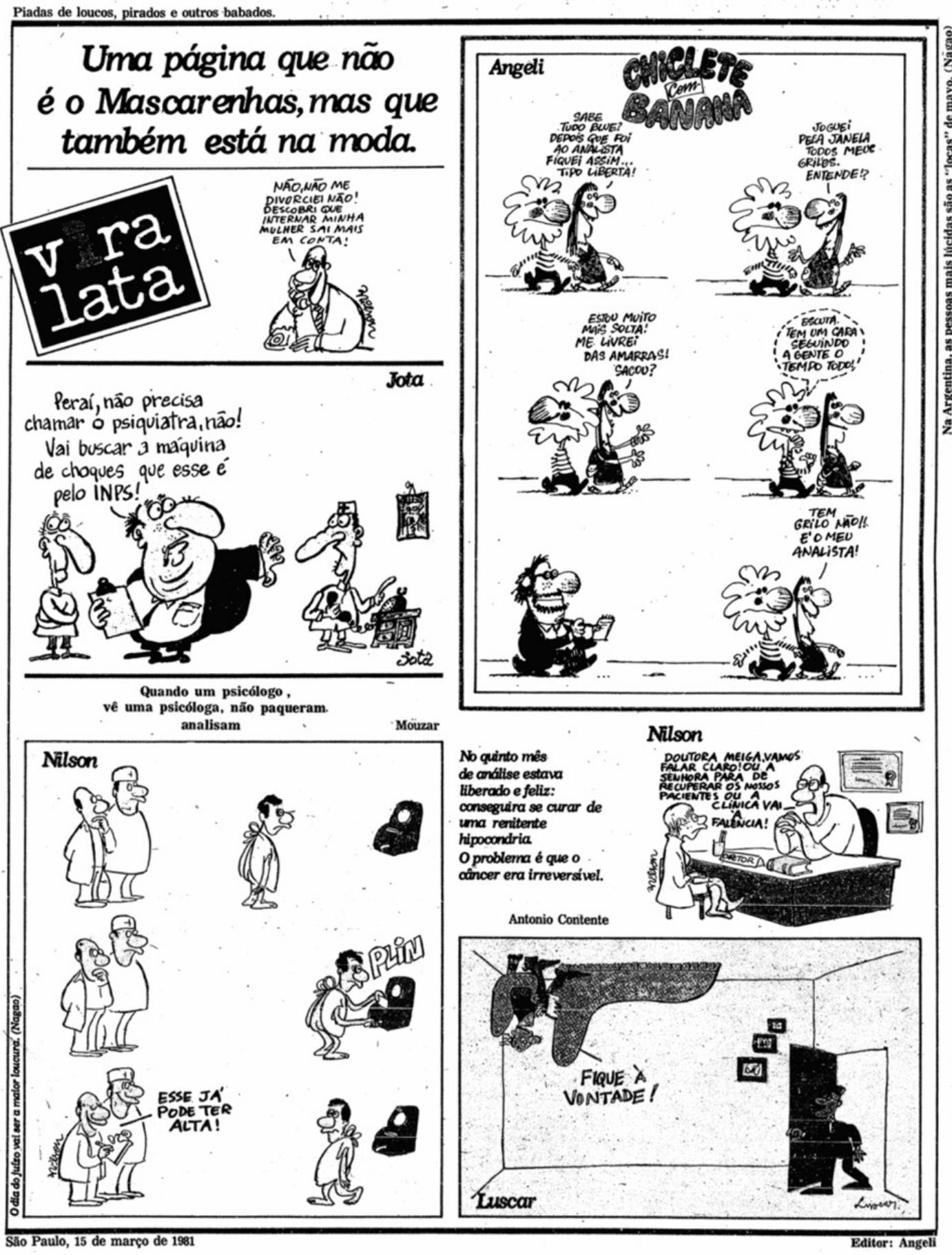

Figura 34 - Primeira versão da Chiclete com Banana 


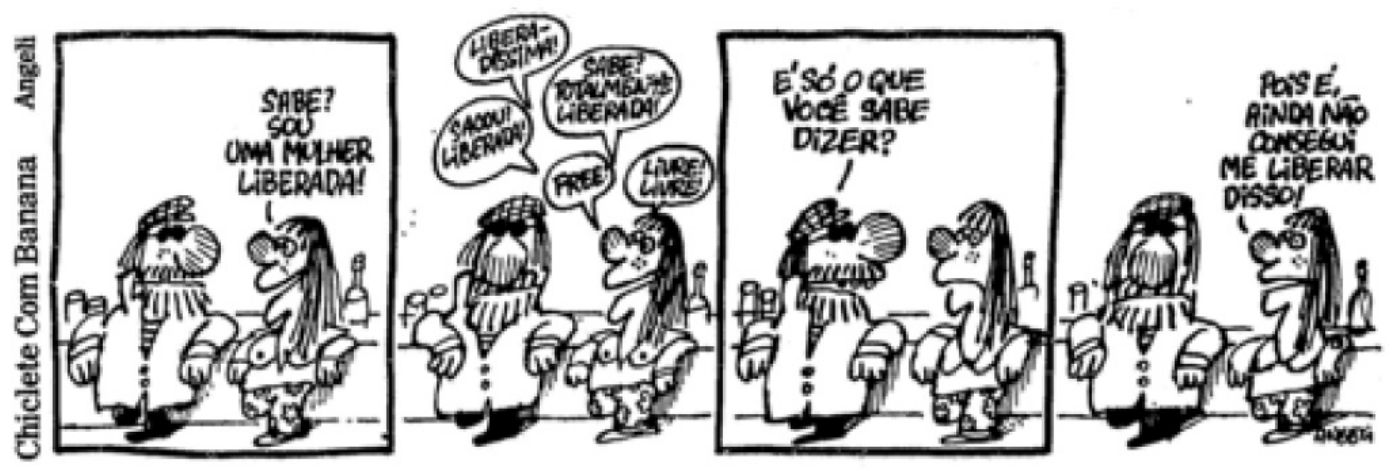

Figura 35 - Primeira tira Chiclete com Banana

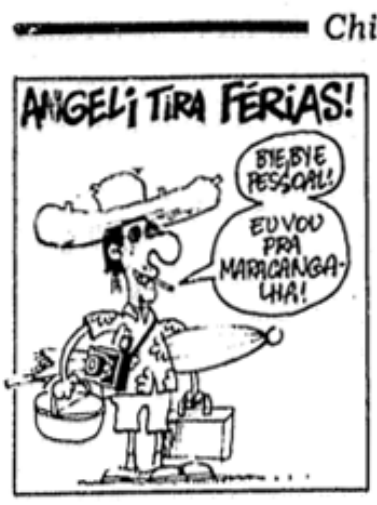

Chiclete com Banana

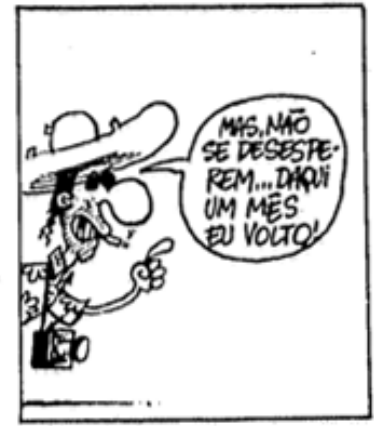

ANGELI
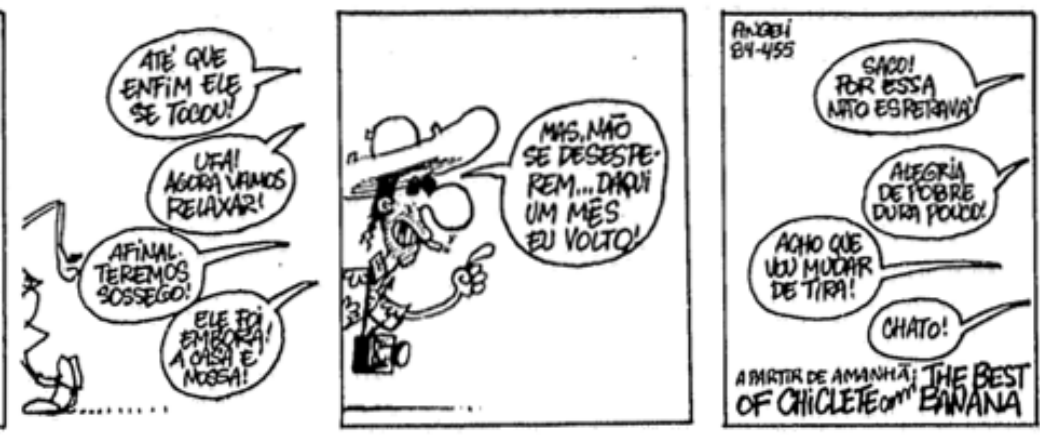

Figura 36 - Primeira aparição de Angeli na Chiclete com Banana

O início da tira Chiclete com Banana é marcada pela participação prioritária de Meiaoito, o revolucionário decadente, militante de bares e botequins. As demais personagens da encarnação anterior da série (Ritapop, Moçamba e Tudoblu) gradativamente perdem espaço paras as novas e icônicas criações de Angeli. O ano de 1983 foi particularmente prolífico, com a estreia de diversas personagens: Nanico (10 de janeiro), um baixinho gay idêntico ao militante Meiaoito; Bob Cuspe (23 de abril), um punk do subúrbio de São Paulo que se diverte disparando cusparadas; Bibelô (26 de julho), um machão à moda antiga, de bigodinho, costeletas, corrente de ouro e comportamento de cafajeste; Benevides Paixão (que embora já aparecesse numa coluna ficcional, estreia como personagem em 18 de agosto), um jornalista decadente obcecado pelo Paulo Francis; Rhalah Rikhota (20 de setembro), um guru de grande apetite sexual, aos moldes do Mr. Natural, de Robert Crumb; e Ritchi Pareide (14 de dezembro), um idiotizado astro de música pop. Essa grande profusão de personagens exemplifica um aspecto bastante particular da série, já que, enquanto as tiras diárias 
normalmente se utilizam de uma personagem (ou um pequeno núcleo) fixo e recorrente, a Chiclete com Banana apresentava um grande número de personagens que revezavam o protagonismo da série. Na verdade, Chiclete com Banana é apenas o título que agrega diversas tiras diferentes num mesmo universo compartilhado, visto o intercambio recorrente entre as personagens. Isso é ressaltado após algum tempo de publicação, quando Angeli começa a identificar qual o protagonista da tira, colocando seu nome no primeiro quadro.

Chiclete com Banana

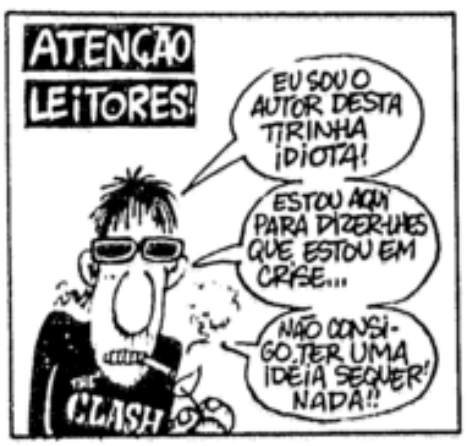

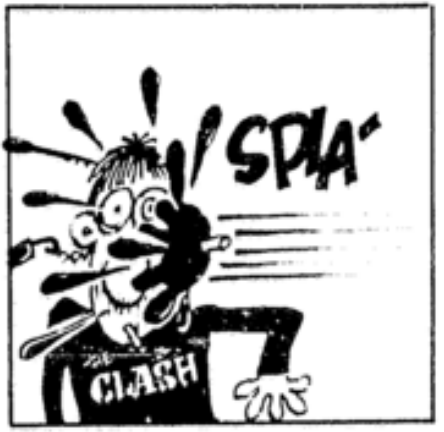

ANGELI

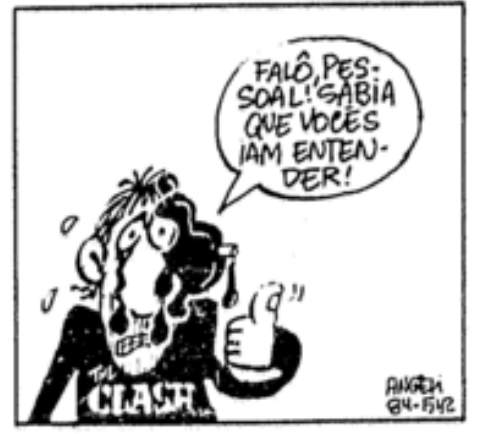

Figura 37 - Tira autobiográfica de Angeli

Em 1984 Angeli cria mais duas personagens de destaque: Rigapov (1 de fevereiro), um enlouquecido senhor da guerra cujo nome remete dos políticos Ronald Reagan e Yuri Andropov; e Rê Bordosa (4 de abril), uma moça boêmia, alcoolista e emancipada, provavelmente sua criação de maior sucesso. Em 17 de abril do mesmo ano, Angeli aparece pela primeira vez como uma personagem de sua tira, anunciando que estava saindo de férias (Figura 36). Embora o caráter de "comunicado" dessa tira a afaste da autobiografia per si em função de efeitos metalinguísticos, essa é a primeira amostra de autorepresentação encontrada em sua obra. Um mês depois, no dia 17 de maio, o retorno de Angeli também é anunciado com uma tira. Nos dois dias seguintes são publicadas duas tiras que, finalmente, podem ser identificadas como autobiográficas. Nesssa narrativas, o autor aborda aspectos de sua experiência diária, representando-se na cama com sua esposa, onde discutem a preguiça e a necessidade de voltar ao trabalho. Em 12 de setembro, Angeli volta à autobiografia, dessa vez introduzindo a temática da "crise", que se tornaria um topoi em sua obra (Figura 37). É interessante destacar que, embora essa tira tenha uma estrutura semelhante aos comunicados de saída e retorno de férias publicados anteriormente, ela se configura 
de forma diferente, abordando aspectos íntimos que ultrapassam o caráter oficial do comunicado. Também não deixa de ser curioso que um autor no auge de seu vigor criativo admita que está tendo problemas em encontrar novas ideias.

O bloqueio criativo anunciado por Angeli parece não ser pura figura de retórica, já que se segue um hiato de dois dias sem tiras publicadas, fato bastante peculiar, considerando que normalmente se republicavam histórias antigas nos dias em que o autor não apresentava novas criações. Em 15 de setembro de 1984 a Chiclete com Banana voltar a ser publicada e apresenta justamente a primeira tira identificada como Angeli em Crise, imediatamente seguida por mais três tiras autobiográficas. Essas quatro tiras (Figura 38) merecem uma análise mais cuidadosa, já que apresentam diversos elementos que seriam desenvolvidos e repetidos à exaustão no desenvolvimento posterior da série Angeli em Crise.
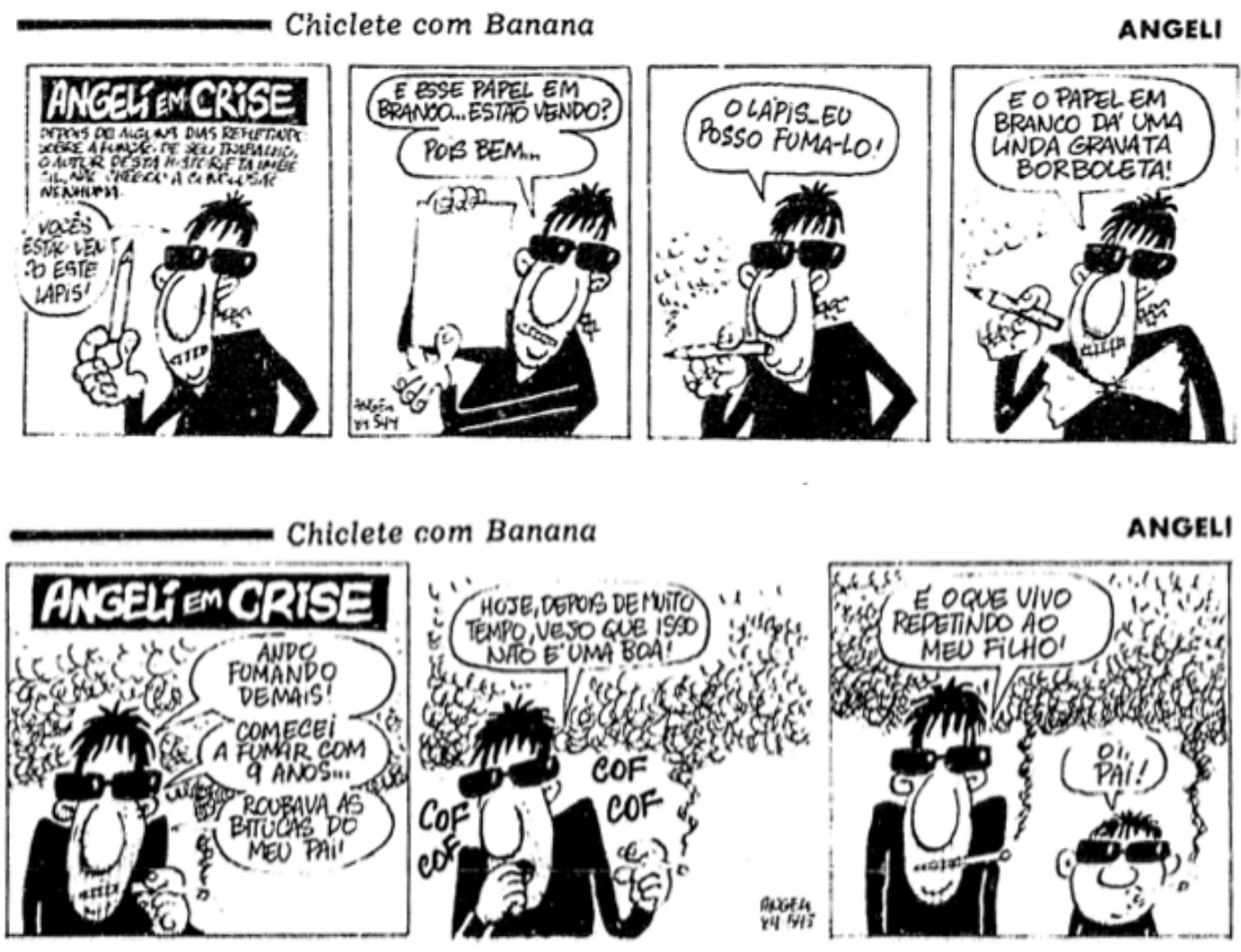

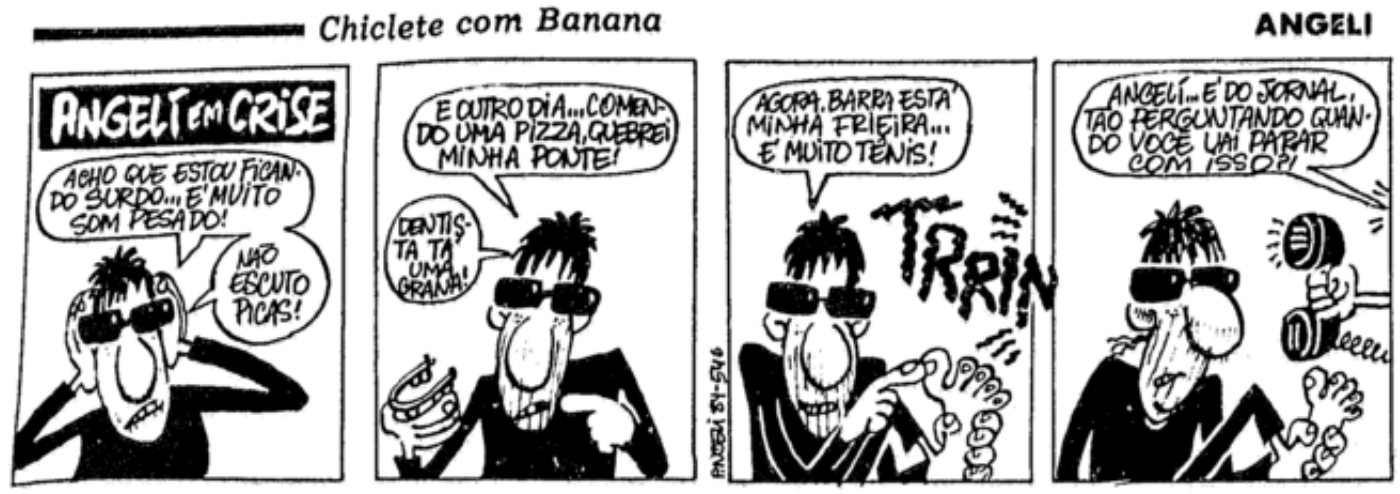

Chiclete com Banana
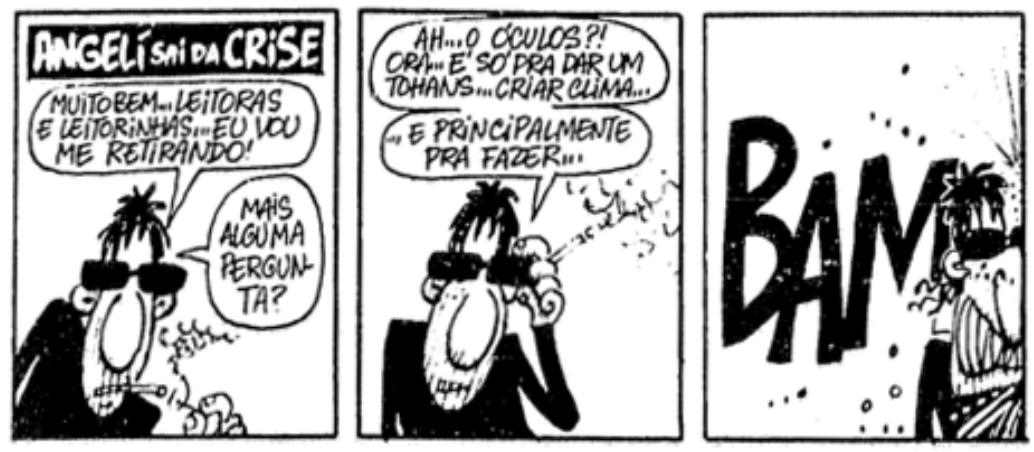

ANGELI

Figura 38 - Primeiras tiras da série Angeli em Crise

Um dos primeiros aspectos que se destacam nessas quatro tiras é a delimitação de uma identidade visual clara para o autor: óculos escuros, nariz proeminente e roupas pretas. Nas tiras autobiográficas anteriores sua aparência mudava bruscamente, mas é fácil perceber que, a partir desse ponto, existe a preocupação em construir um modelo de representação que seja facilmente identificável. É nesse momento, portanto, que Angeli se torna uma “personagem”. O caráter humorístico dessas narrativas também é bastante acentuado. Mesmo que esteja falando de experiências reais de sua vida, o objetivo principal dessas tiras é serem engraçadas, assim como as demais criações do autor (Rê Bordosa, Bob Cuspe, etc). Dessa abordagem humorística decorrem dois recursos narrativos que se tornariam recorrentes: emprego de motes completamente irrelevantes, como na tira onde se fala sobre seus pequenos problemas de saúde; e a utilização de dados biográficos que são extrapolados até se tornarem cômicos, como na tira sobre o hábito de fumar. A última dessas tiras exemplifica ainda o elemento metalinguístico utilizado ocasionalmente. Obviamente, todos esses monólogos da série Angeli em Crise são destinados ao leitor, mas em alguns momentos esse contrato de leitura é 
modificado e o autor/personagem interpela diretamente o leitor. Além disso, o mote da "crise" provoca deslizamentos interessantes de sentido já que, conforme posto pelo autor, essas tiras autobiográficas seriam uma alternativa para os momentos em que não conseguiria fazer seu trabalho costumeiro. Partindo dessa concepção, Angeli em Crise seria uma espécie de trabalho "não criativo", um momento em sua vida comum ocupa o espaço da ficção. A elaboração prática da tira demonstra exatamente o contrário, já que Angeli prossegue com o mesmo estilo humorísticos de suas tiras ficcionais. Em certo sentido, a própria existência desses quadrinhos autobiográficos desfaz o sentido da "crise", já que a produção continua e novos produtos são apresentados ao público.

Outro aspecto interessante dessa manifestação inicial é que na última dessas quatro tiras o autor anuncia que está saindo da "crise". Com efeito, na edição seguinte do caderno Ilustrada a Chiclete com Banana apresenta uma história da personagem Meiaoito. É difícil precisar se o otimismo presente no título "Angeli sai da crise" se refere apenas ao momento imediato ou se autor realmente pensava em abandonar esses exercícios autobiográficos. O certo é que a série Angeli em Crise tornou-se sua criação mais recorrente e longeva. Observando, mesmo que superficialmente, a carreira de Angeli é possível perceber o quanto o autor respeita o ciclo natural de vida das suas personagens. Enquanto séries cômicas tradicionalmente se apegam a suas personagem por décadas (como Peanuts, Garfield, Hagar, etc), as criações de Angeli têm vida curta. Em determinados casos, o autor se encarrega de dar um fim tragicômico às suas personagens: Rê Bordosa morre de tédio após se casar com Juvenal, o garçom do bar frequentado por ela; e Meiaoito é atropelado por um caminhão da Coca-Cola. Mas, normalmente, suas personagens são substituídas por outras sem grande estardalhaço, conforme os motes cômicos começam a apresentar desgaste. A única criação que se mantem constante em sua produção são justamente as histórias autobiográficas, seja na série Angeli em Crise ou encarnações mais recentes, como $O$ Velho Cartunista.

Quando é iniciada a revista Chiclete com Banana, em 1985, o projeto de exploração autobiográfica desenvolvido por Angeli ganha contornos mais nítidos. A liberdade editorial e o espaço mais amplo permitiram que o autor se aventurasse em narrativas mais longas. De início, essas histórias eram protagonizadas por seus personagens mais populares e, posteriormente, também são publicadas narrativas autobiográficas de maior duração. No que se refere à natureza do material veiculado 
na revista Chiclete com Banana faz-se necessário alguns esclarecimentos. Quando se compara o material da revista e as tiras publicadas no jornal Folha de S. Paulo fica claro que Angeli utilizava três procedimentos distintos para reaproveitar o conteúdo de sua produção diária: algumas vezes a tira era redesenhada para a revista, sem modificação de conteúdo, medida provavelmente tomada para evitar grandes diferenças no estilo; a ideia de uma tira também poderia ser utilizada como base para uma história mais longa (normalmente de uma página), onde se dilatava o mote da piada sem se distanciar do conteúdo original; e, finalmente, as tiras que eram reaproveitadas sem modificações, exceto a aplicação ocasional de retícula.

Nos 12 primeiros números da Chiclete com Banana a presença dessas tiras reaproveitadas é bastante pontual, já que quase todo conteúdo dessas edições era inédito. A própria disposição solta e experimental das vinhetas dos quadrinhos denota que o material foi concebido para as páginas da revista. Esse design orgânico contrasta com o esquematismo da diagramação em bloco necessário para dispor as tiras na página da revista, procedimento que ficaria mais comum nas últimas edições, conforme esclarece Vergueiro:

Pode-se dizer que os onze primeiros números da Chiclete com Banana representaram uma primeira fase da revista, na qual Angeli reinou de forma praticamente absoluta. A partir do número 12, sutis modificações foram iniciadas, e a revista começou a mudar de cara. Angeli passou a produzir menos, o reaproveitamento de tiras já publicadas em jornais se tornou mais frequente e o espaço de outros colaboradores foi ampliado (VERGUEIRO, 2014, p.50).

A introdução de novos colaboradores mostrou-se muito benéfica para a revista, que já apresentava sinais de cansaço. Nas primeiras edições Angeli era responsável pelos quadrinhos, textos humorísticos diversos e pelas colunas de Benevides Paixão e Edi Campana, limitando as colaborações de outros artistas a uma história por edição. Essa centralização em torno da figura de Angeli, ao mesmo tempo em que estipulava uma identidade muito forte, transmitia também um tom monocromático à publicação. O processo de abertura e diversificação da Chiclete com Banana, iniciado na edição 12, se intensifica a partir do número 18 , quando o número de quadrinhos, textos e fotonovelas de autoria de Angeli diminui 
consideravelmente. Essa variação é bastante significativa: na primeira edição, Angeli é responsável por $73 \%$ do número total de páginas; na edição 18, a porcentagem cai para 44\%; e na edição 24, apenas $30 \%$ das páginas são de autoria de Angeli.

A maior abertura para outros quadrinhistas, como Marcatti e Luiz Gustavo, além das novas colunas, como Banana Purgativa, de Glauco Mattoso e Rancor, de Furio Lonza, introduziam novas vozes na Chiclete com Banana. A polifonia estaria completa com o lançamento do suplemento JAM na edição 16. Inspirado no encarte MAU, que estreou na revista Animal dois meses antes, JAM foi uma das mais interessantes criações da revista. Sua diagramação, completamente caótica, (Figura 39) diferia completamente do resto da revista, aproximando-se da estética dos fanzines, Essa impressão é reforçada pelo grande número de colaboradores que recebia por edição (em alguns casos, chegava a 18), numa profusão de pequenos textos, colunas, fotomontagens, desenhos, críticas musicais, quadrinhos e até mesmo uma seção onde se fazia uma análise comparativa dos produtos mais incomuns, como absorventes íntimos, chicletes, banheiros de bares e caixas de fósforo.

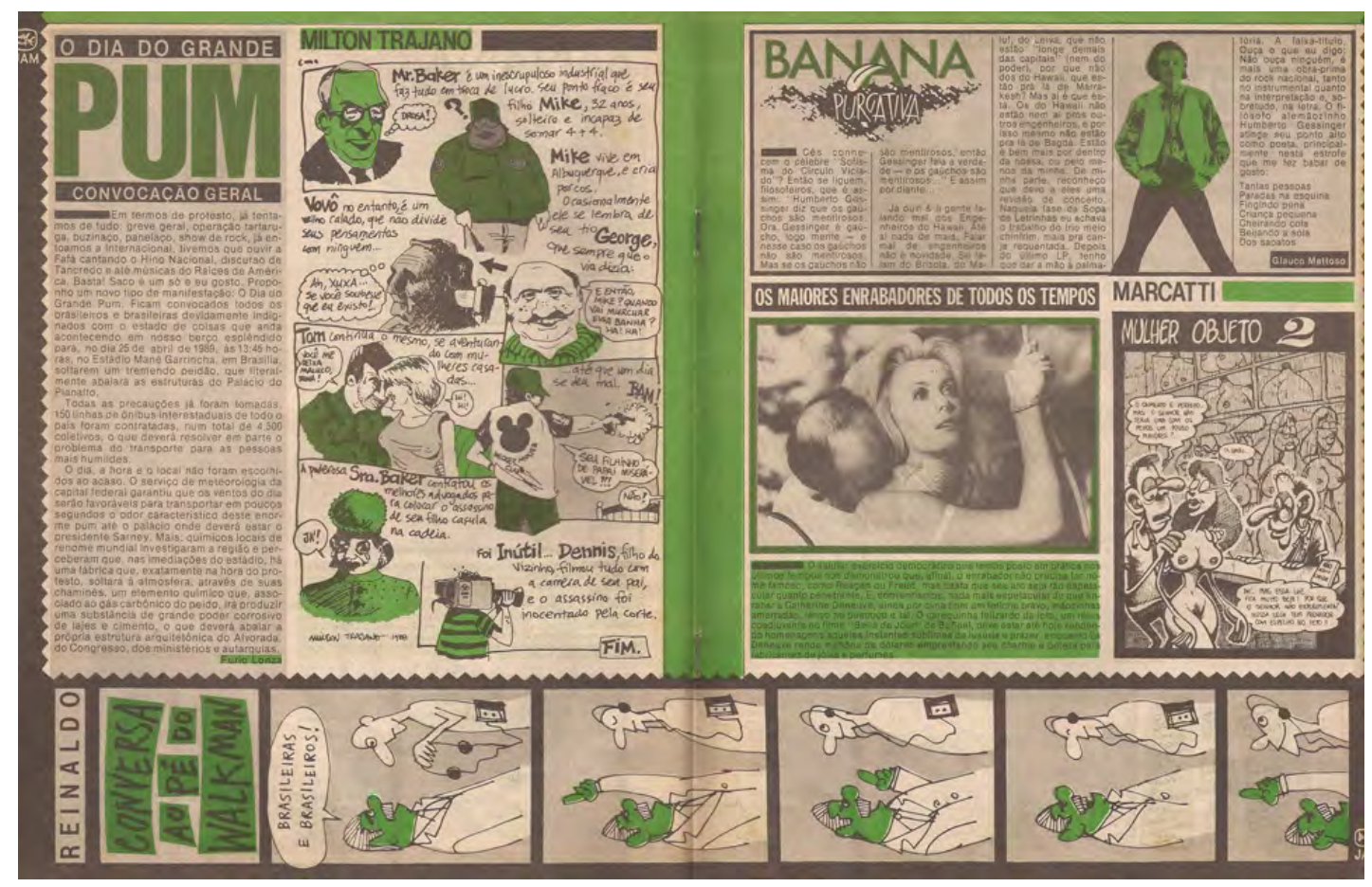

Figura 39 - Suplemento JAM da Chiclete com Banana nº 18

Conforme a participação de Angeli diminui na revista, as manifestações de autorepresentação também se tornam menos frequentes. Na primeira fase da Chiclete com Banana, a figura do autor estava por toda parte: fotos no editorial, 
protagonizando fotonovelas, tiras autobiográficas e autorretratos diversos. É interessante destacar que nas outras revistas de autor da Circo Editorial, como Geraldão, Piratas do Tietê e Niquel Náusea, não havia essa representação constante dos autores Glauco, Laerte e Fernando Gonsales. Este parece ser um traço bastante característico do estilo de Angeli. Vejamos, a título de exemplo, o quanto a figura de Angeli se mostra presente na edição $n^{\circ} 1$ da Chiclete com Banana. $\mathrm{Na}$ página de expediente o autor aparece travestido de vampiro, prestes a morder o pescoço de uma moça. Na primeira história da revista (desconsiderando o "editorial em quadrinhos" Hit Hit Hurra! O Melhor do Rock), intitulada Bob Cuspe é a Salvação, encontramos um interessante exercício de metalinguagem, onde o autor se introduz como um narrador que parodia um estilo infantil: "Muito bem, amiguinhos... Para vocês não votarem no escuro, veja nas páginas seguintes, quem é e o que é Bob Cuspe! Sigam o Titio”. Das nove páginas que essa história ocupa, Angeli está presente em seis, inclusive no último quadro da história, sentado em sua prancheta (Figura 40). Na página 26 também há um pequeno autorretrato do autor com uma chupeta na boca, referência à sequência de tiras sobre a mãe e o pai da personagem Rê Bordosa. Na página 40 acontece a primeira publicação da série Angeli em Crise na revista (Figura 41): uma tira solitária sobre a dificuldade para criar um novo personagem, posicionada entre as mensagens dos leitores na seção Uppercut - $a$ porrada do leitor (como essa era a primeira edição da revista, Angeli utilizou cartas que recebeu de leitores da Folha de S. Paulo).

Nas edições seguintes, seria comum a presença de Angeli nas fotonovelas e em fotos do índice ou editorial. No que se refere aos quadrinhos autobiográficos propriamente ditos, ocorre uma dispersão curiosa, já que embora essas histórias fossem mais comuns na primeira fase da revista, as narrativas mais consistentes aparecem nas edições finais. Assim, na página 4 da Chiclete com Banana n², sob o título "A voz do dono", são reunidas três tiras da série Angeli em Crise. Ao contrário das outras tiras publicadas na revista, onde o espaço entre os quadros é maior na horizontal (o que reforça a estrutura individual da tira), nessa página a diagramação se mantem regular, transmitindo uma sensação da unidade, como se fosse uma história de 9 quadros. Esse recurso editorial de reunir tiras de temática semelhante, na tentativa de simular uma narrativa longa, seria recorrente em boa parte das suas histórias autobiográficas publicadas na revista. 


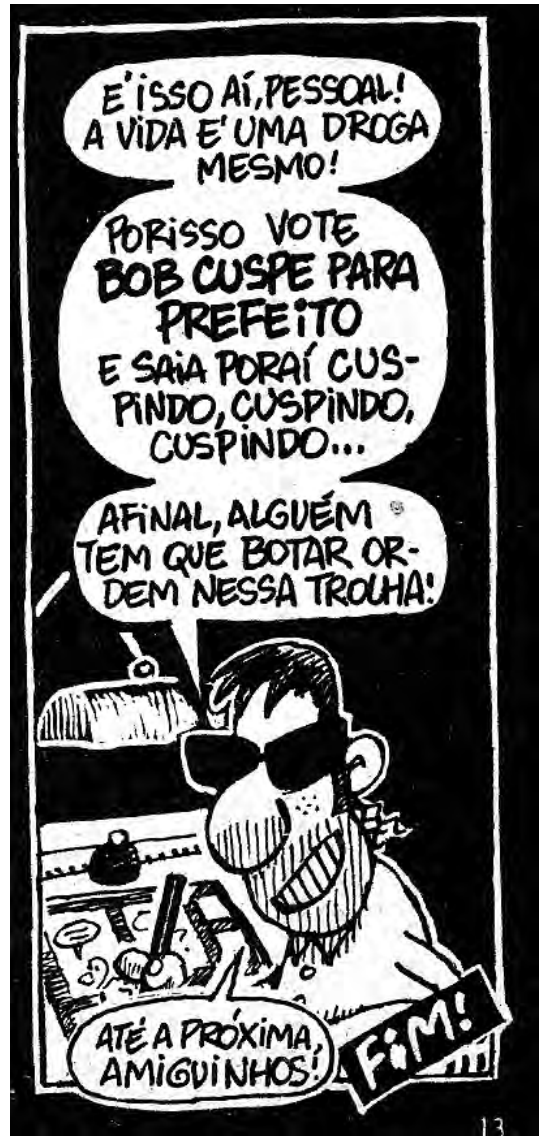

Figura 40 - Autorepresentação de Angeli amigos de uma certa forma,
estão sem fé nem espe-
rança.

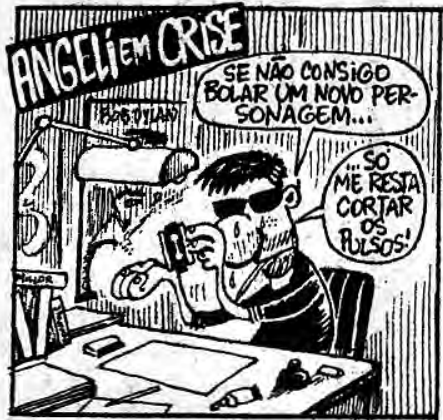

\section{CRISE? QUE CRISE?}

gosto e porque hoje à noite ao pegar meu carro, no vidro da janela havia uma

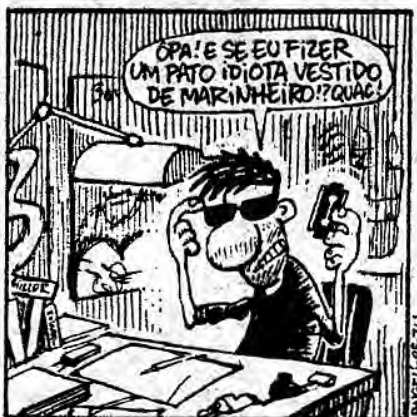

Aderbal Brasil somos todos nós. janela do seu carro, não tenho culpa. Quem mandou ter um carro tão imponente

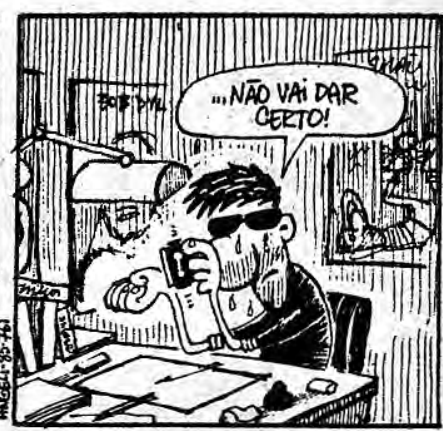

todo coração que da próxima vez que entrar numa

Figura 41 - Primeira publicação da série Angeli em Crise na revista

Na Chiclete como Banana n 3 , "A voz do dono" trás uma história original, de nove quadros, onde o autor tenta resolver uma crise criativa da madrugada ligando para a modelo Luiza Brunet. Na edição 4, a diagramação do expediente muda para a vertical. Do lado inverso, uma história de 3 quadros da série Angeli em Crise (Figura 
42) Na página 21, Angeli e Glauco desenham Swing, uma surpreendente história de troca de casais. Essa edição traz ainda "Os broncos também amam", pequena peça de autobiografia em prosa onde Angeli relembra sua vida escolar de forma bem humorada. Depois de explanar acerca de suas travessuras e da péssima formação escolar que obteve, justifica:

O motivo dessas linhas é o fato de um leitor ter enviado uma carta a Folha de São Paulo, apontando bondosamente um dos meus erros crasso. Fiquei sem ter onde enfiar a cara. O certo seria enfiá-la num bom livro de gramática ou então nos seios de uma bela revisora que, na certa, falaria: seios é com 'esse' e não com 'cê-cedilha" (ANGELI, 1985, p.25).

Apesar da edição mais cuidadosa de Toninho Mendes, a revista Chiclete com Banana ainda publicou alguns erros ortográficos bastante chamativos, como a palavra "passoca" na coluna o Edi Campanha, escrita por Angeli (edição 9, p.33).

A Chiclete com Banana $n^{\circ} 5$ é particularmente rica em histórias autobiográficas e exercícios metalinguísticos. A recorrente história autobiográfica curta publicada no editorial é substituída pela primeira história mais longa (5 páginas) da série Angeli em Crise (Figura 43). Chama atenção essa história não ter um título particular ou ao menos um subtítulo, assumindo apenas o nome geral da série. Apesar do tamanho mais extenso, essa história é pouco consistente, concentrando-se em um suposto encontro de Angeli com uma moça em um bar. Primeiro a moça o assedia, é rejeitada e ameaça se matar; depois, já no apartamento de Angeli, a situação se inverte. De modo geral, a impressão que essa história transmite é de uma gag simples que é estendida por um número desproporcional de páginas. Nas páginas 23 e 24 , mais uma história feita a quatro mãos com o Glauco, uma estranha narrativa protagonizada pelos pênis dos cartunistas. Na página 33, outra narrativa autobiográfica em prosa: "E agora são Cinzas", onde relembra, desde a infância, sua trajetória de fumante inveterado.

Na edição 6 é publicada uma página (5 quadros) da série Angeli em Crise junto ao expediente. Na página seguinte a história "A vaca vai pro brejo" mostra o autor recebendo em casa a visita da desiludida vaca do título. A edição 7, novamente trás Angeli em Crise na página do expediente. O autor aparece ainda na última página 
da história "O sexo das bactérias", alegando ter passado uma noite com Mara Tara, e na história "Bob Cuspe em Leite com Nescau", onde acalma os leitores com a frase: "Não se aflijam: o mundo ainda é dos idiotas". Curiosamente, não é publicada nenhuma história autobiográfica na Chiclete com Banana n ${ }^{\circ} 8$.
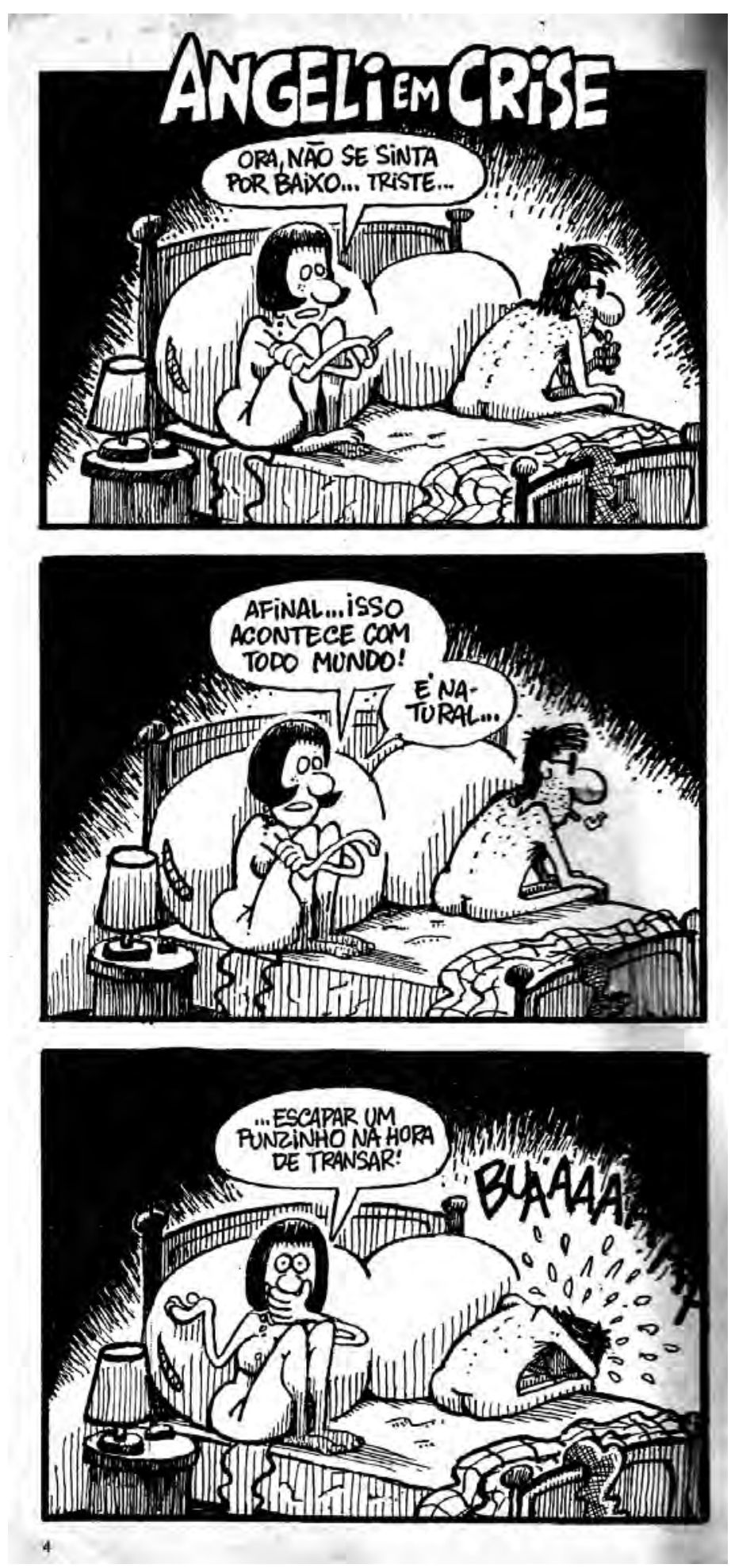

Figura 42 - Angeli em Crise na Chiclete com Banana ${ }^{\circ} 4$ 

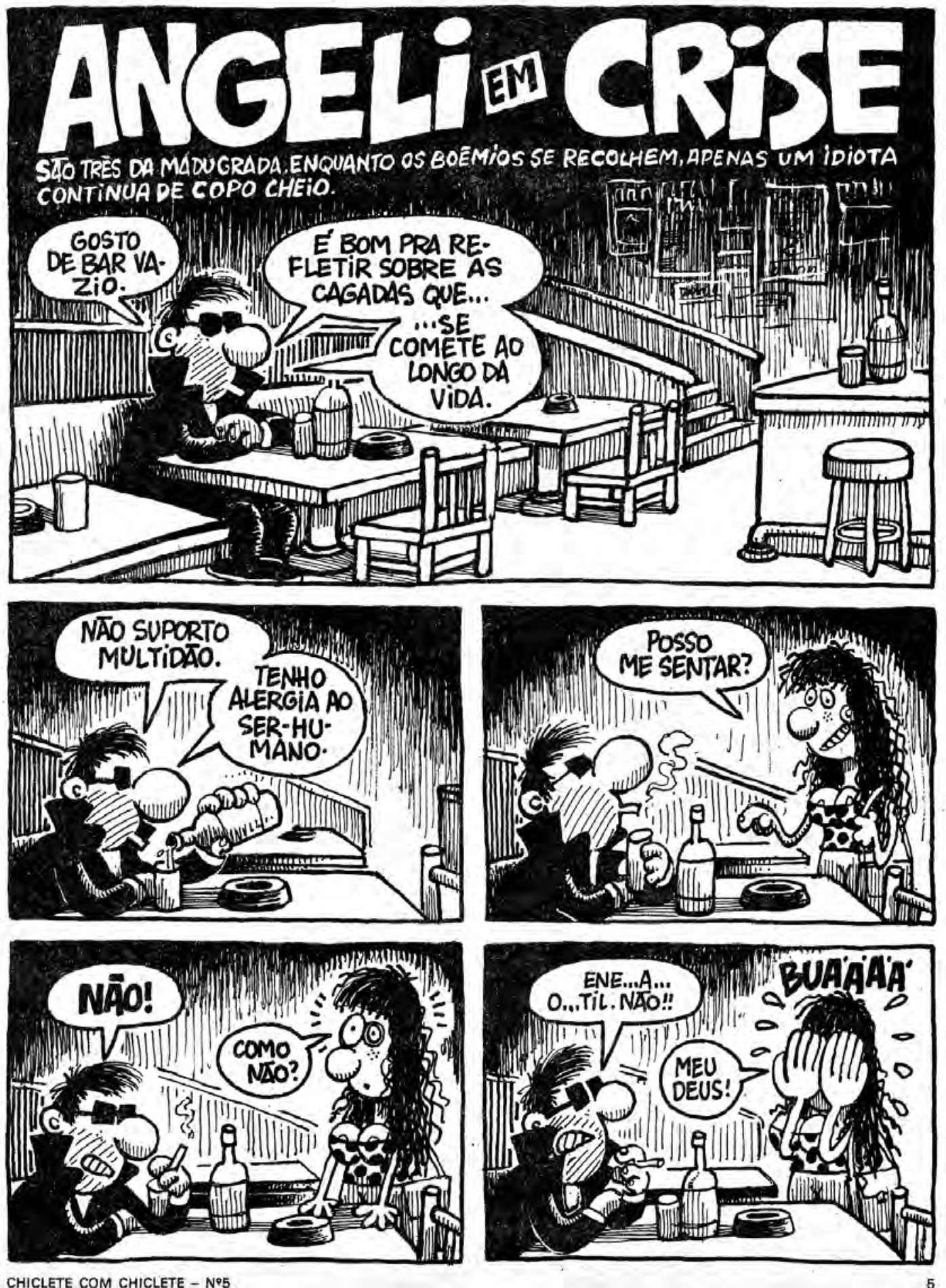

Figura 43 - Primeira história longa da série Angeli em Crise

Angeli anda na rua sob uma chuva de mulheres desenhadas por Laerte no editorial da edição 9. O autor aparece ainda no encerramento da história "Psicoburguês", travestido de Che Guevara, e faz uma pequena figuração na história "Os anos 90 vão ser sodinha", acorrentado e nu em um calabouço. Na edição 10, o 
editorial traz "A mente suja de um autor imundo", uma ilustração onde a cada parte do cérebro é ligada um aspecto mnemônico: "As pernas da dona Cidinha, minha professora de primário", "As veias de Jimmy Hendrix", "O traço de Crumb”, etc (Figura 44). Na edição 11 não constam histórias autobiográficas e nas edições 12, 13, 14 e 15 constam apenas as criativas histórias da série Los Tres Amigos. As histórias autobiográficas são retomadas na edição 16, com "As sete libélulas", uma história de 5 páginas que curiosamente não carrega o título Angeli em Crise. "As Sete Libélulas" é provavelmente a história autobiográfica mais consistente produzida por Angeli para a Chiclete com Banana. Nessa breve narrativa o autor se afasta da piada fácil, concentrando-se em elementos de grande potencial simbólico. Em certo sentido, a história representa o casamento: no início as libélulas garantem que vão atender todos os desejos de Angeli; depois começam a fazer exigências e reclamar do tratamento pouco atencioso; e finalmente, o aprisionam na cama. Nesse ponto, o instinto selvagem leva ao desenlace cômico, quando Angeli se transforma em uma "besta fera" e devora as libélulas (Figura 44).

$\mathrm{Na}$ Chiclete com Banana $\mathrm{n}^{\circ} 17$ estreia no editorial um novo tipo de narrativa autobiográfica, intitulada Listen to the music, onde o autor brinca de disc jockey (Figura 45). Nas edições 18, 19 e 21 não constam histórias autobiográficas. Nos números 20 e 22, novamente é publicada uma tira da série Listen to the music. A edição 23 marca a volta da narrativas autobiográficas, com "Que tudo mais vá pro inferno", história de 4 páginas que dá continuidade ao modelo de autoficção iniciado em "As Sete Libélulas". Nesse quadrinho, o autor ainda está muito preocupado em seguir as diretrizes do humor (ou da piada, melhor dizendo), mas pela primeira vez aborda as questões as concretas que lhe afligem. Como o próprio título já deixa entrever, essa narrativa mostra a peregrinação de um autor cansado da fama, da profissão de desenhista, dos patrulhamentos morais e ideológicos, dos problemas decorrentes dos relacionamento afetivos e das convenções sociais. Podemos afirmar que esse é o único momento onde a personagem "Angeli em Crise" abre um pouco o espaço para o indivíduo Angeli. Mesmo sob o eterno verniz do humor, é possível perceber o desencanto o autor perante a vida. A penetração de dados biográficos concretos ante a idealização da narrativa cômica também é muito clara: pela leitura das sessões de cartas é possível perceber que Angeli havia se separado há pouco e, na última página, sua ex-esposa leva os filhos para visitá-lo na jaula onde ele está em exposição (Figura 45). De determinada maneira, essa é a narrativa performática e 
humorística da vida desregrada e sem alicerces que o autor encontra após sua separação. Nessa mesma edição também é publicada uma história da série Listen to the Music, onde Angeli entrevista John Lennon. Finalmente, na última edição da Chiclete com Banana, é publicada uma página com quatro tiras da série Angeli em Crise. Por coincidência, essa foi a última história em quadrinhos publicada na revista (Figura 46).
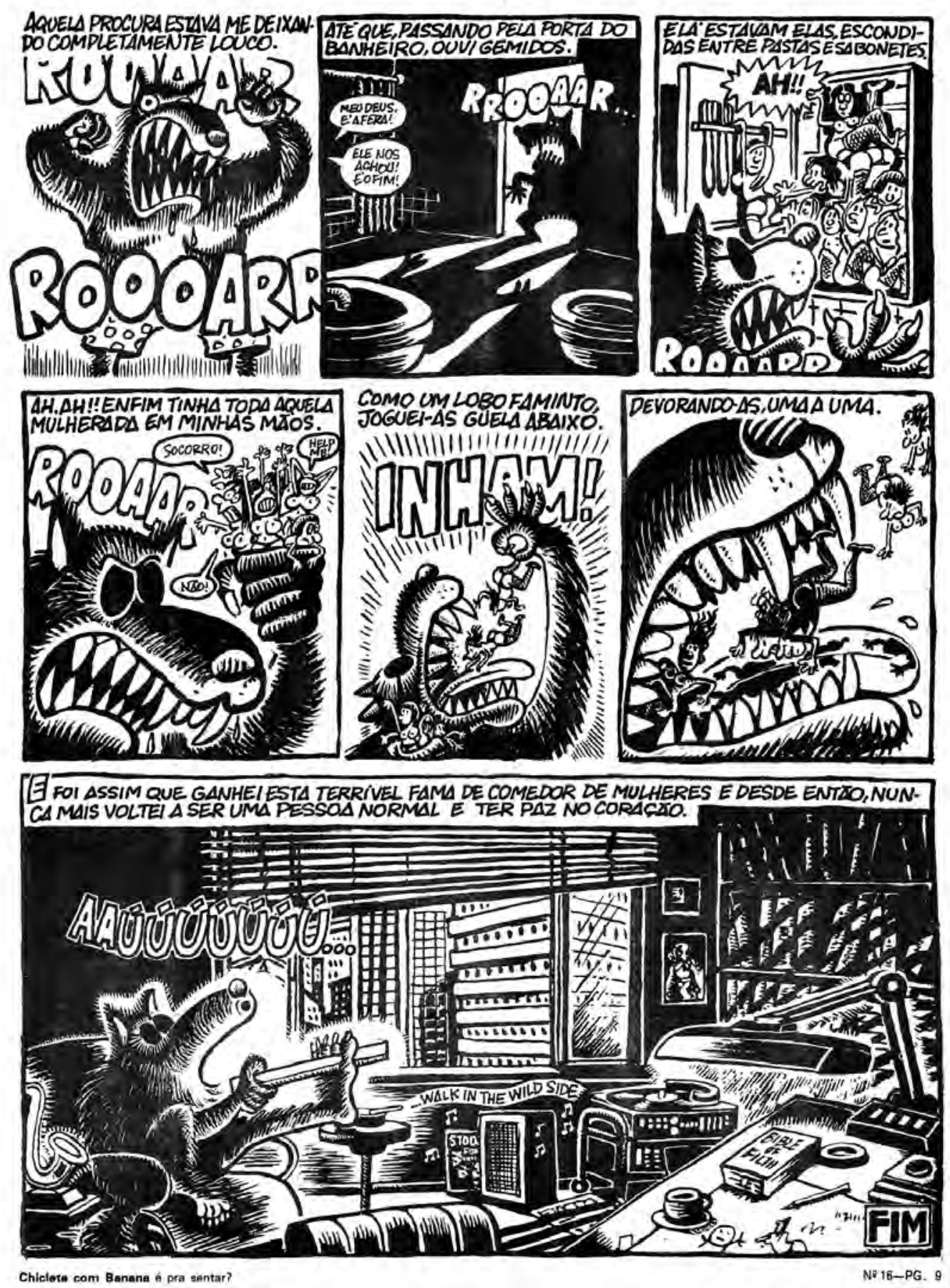

Figura 44 - As sete libélulas 

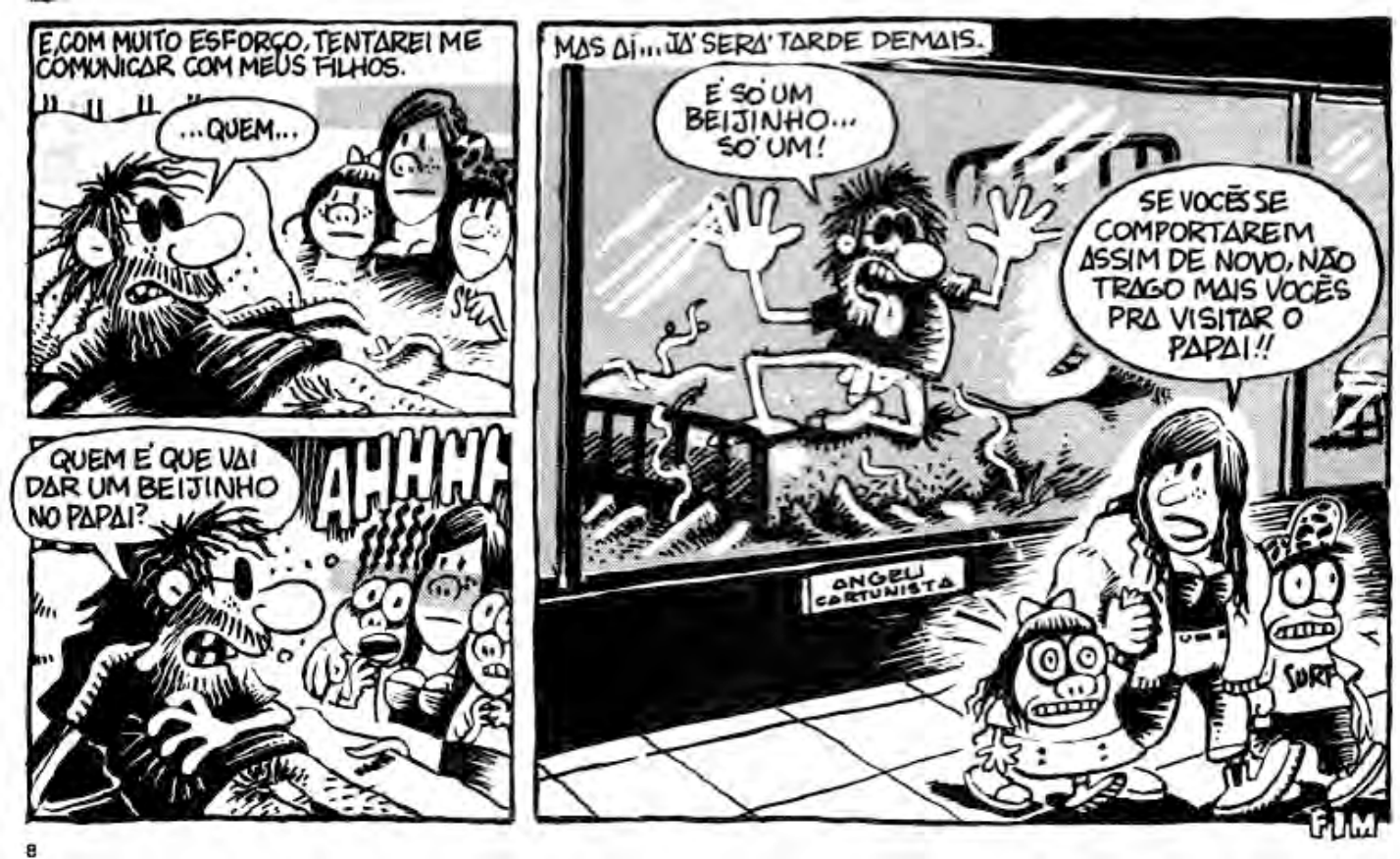

Figura 45 - "Que tudo mais vá pro inferno", de Angeli

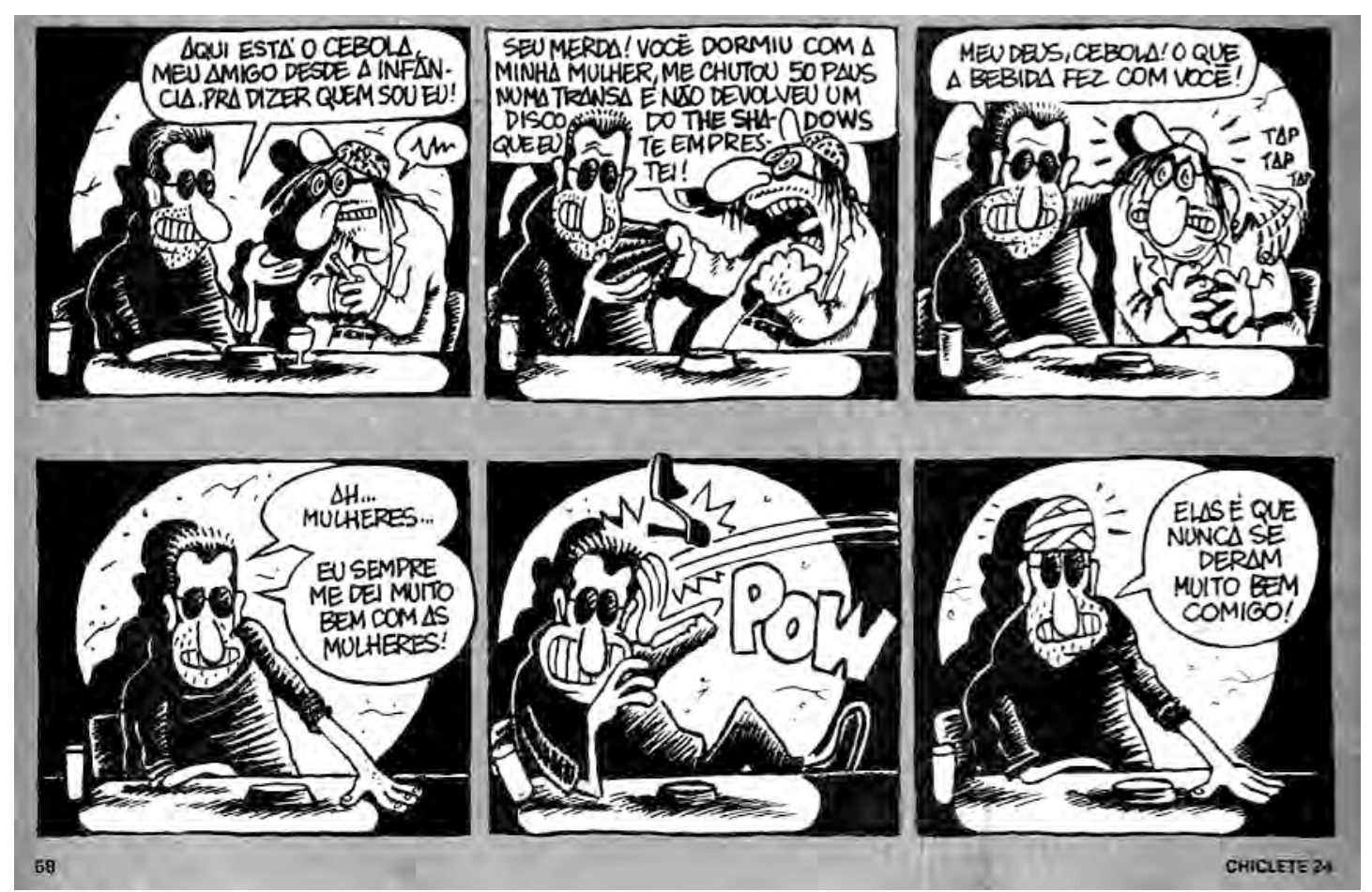

Figura 46 - Últimas tiras da série Angeli em Crise na Chiclete com Banana 


\subsection{Pictografia e humor gráfico}

Durante da década de 1980, Angeli consolidou um estilo gráfico icônico e facilmente reconhecível: linhas de contorno bem definidas, com hachuras ocasionais; personagens cartunizados, de narizes proeminentes e quase sempre usando óculos escuros; uma abordagem cômica e distorcida das expressões faciais; e a construção de cenários simplificados, minimalistas ou mesmo inexistentes. Quando o autor inicia suas primeiras produções autobiográficas, em 1984, utiliza-se dessas mesmas convenções estilísticas típicas das produções ficcionais e jornalísticas. Esse é um dado bastante significativo, por dois aspectos. Primeiramente, identificamos entre os criadores responsáveis pelo desenvolvimento da autobiografia nos Estados Unidos, como Robert Crumb, Art Spiegelman e Justin Green, a tentativa concreta de construir modelos de representação eficientes, que reforcem a relação de referencialidade entre seus estilos pictográficos e a realidade visual. Angeli, por sua vez, não se preocupa em reproduzir com algum nível de fidelidade a aparência de objetos, pessoas, paisagens, etc. Em segundo lugar, normalmente existe uma tendência entre os quadrinhistas a construir representações mais realistas na autobiografia, quando comparadas a suas produções ficcionais (conforme demonstramos na análise da pictografia na obra de Crumb). Novamente, Angeli não faz qualquer distinção entre o estilo de suas histórias autobiográficas ou ficcionais. As mudanças observadas na sua configuração pictográfica dizem respeito apenas à evolução natural de seu estilo gráfico, de modo que não são encontradas variações significativas dentro de um mesmo espaço de tempo.

O comprometimento da autobiografia de Angeli com as convenções do humor gráfico torna-se ainda mais curioso quando consideramos a grande influência dos quadrinhistas do underground norte-americano, particularmente Crumb, sobre seu estilo (VERGUEIRO, 2014, p.35). Embora a relação entre os comix e os quadrinhos desenvolvidos por Angeli e demais artistas da Circo Editorial seja bastante palpável, existem determinadas características que extrapolam a relação desse feixe de influências. Conforme esclarecemos anteriormente, o contexto do desenvolvimento dos quadrinhos adultos, underground ou de vanguarda no Brasil diferem bastante da matriz norte-americana, principalmente em decorrência da censura implantada durante o Regime Militar. Devido a esse hiato de quase 20 anos, a relação entre os comix e o "udigrudi" brasileiro acorre mais por um processo de ressonância que de 
influência direta. Quando as inovações formais e temáticas do underground norteamericano começam a encontrar eco na produção nacional, encontram um ambiente cultural completamente diverso do contexto norte-americano em que os comix foram desenvolvidos. A contracultura dos 1980 no Brasil era mais agressiva, pessimista e sombria: carecas, punks e darks substituíam os hippies; as drogas se tornavam mais pesadas; e a apatia tomava o lugar dos sonhos utópicos de uma sociedade mais livre e justa. Além desse contexto cultural, aspectos formais também incidem sobre apropriação dos comix perpetrada pelos artistas brasileiros, já que todas inovações acabaram sendo resignificadas a partir da forte tradição do humor gráfico brasileiro.

$\mathrm{Na}$ seção Uppertcut da revista Chiclete com Banana $\mathrm{n}^{\circ} 1$, Angeli, respondendo a uma carta do cartunista Iotti, faz um declaração bastante esclarecedora: "Basta olhar essa revista para ter uma lista de minhas influências: Robert Crumb, Jaguar, Wolinski, Millôr, Reiser, Ivan Lessa, Barão do Itararé... e muitos outros". Como se pode perceber, além do onipresente Crumb, são citados vários criadores gráficos brasileiros. Santos (2011, p.158) destaca ainda "o humor satírico e político do cartunista Henfil" como influência marcante. Em grande medida, essa proximidade de obra de Angeli com o humor gráfico está atrelada a sua atividade profissional na Folha de S. Paulo e, se considerarmos um contexto mais amplo, uma parcela considerável da produção mais criativa dos quadrinhos no Brasil é destinada a jornais e revistas. Essa ligação entre os quadrinhistas e a imprensa ocorre principalmente devido à fragilidade do mercado de histórias em quadrinhos nacionais, cuja precariedade muitas vezes impossibilita que o artista sobreviva apenas dos direitos autorais de suas criações. A imprensa com viés humorístico, por outro lado, já se mostrava um empreendimento viável desde o século XIX (COSTA, 2012; SALIBA, 2002, p.47), criando uma forte demanda por criações gráficas. Com o tempo, esse processo seria intensificado, conforme elucida Santos:

O lançamento de vários títulos de revistas ilustradas, no início do século XX, contribuiu para a difusão da caricautura [sic.], da charge política e do cartum humorístico. Ilustradores como J. Carlos, Belmonte e Péricles tornaram artistas consagrados e figuras importantes da cultura brasileira (SANTOS, 2004, p.3). 
Quando observamos o trabalho de Angeli, particularmente o início de sua carreira, é possível perceber o quando da tradição gráfica brasileira está presente no seu estilo. Segundo Santos (2004, p.2), essa relação é bastante natural, já que "a charge política, a caricatura e o cartum humorístico influenciaram o quadrinho de humor". Contudo, observamos que apesar da atuação de Angeli na imprensa diária, essa influência ocorre muito mais pela via das convenções do cartum que da caricatura política propriamente dita. De certa forma, a simplicidade do estilo gráfico de Angeli pode ser explicada a partir dessa proximidade, tendo em vista que a caricatura tende para um maior realismo quando comparada ao cartum.

A própria natureza da caricatura a aproxima da experiência da realidade visual. Seu procedimento consiste em observar a aparência de um indivíduo e distorce-lo até um ponto em que ainda possa ser reconhecido, processo normalmente desenvolvido com intenções cômicas. Segundo Jacques Aumont (1993, p.82), o caricaturista capta as invariâncias do rosto, que não necessariamente são notadas a princípio, mas que, a partir de então, poderão desempenhar papel de índice de reconhecimento. Antes de constituir-se como um gênero do jornalismo, a caricatura era principalmente um recurso artístico utilizado para construir figuras grotescas. Conforme Gombrich (2007, p. 290), os irmão Carracci foram os responsáveis pela criação desse estilo de retrato satírico, ainda durante o século XVI. George Minois (2003, p.299), por sua vez, destaca que os Carracci foram responsáveis pelo processo de "civilização" da caricatura, já que esses retratos irreverentes seriam comuns desde as pichações romanas. A popularização da caricatura como gênero jornalístico e arma política só iria ocorrer no século XVIII, particularmente a partir do trabalho seminal de Honoré Daumier (MINOIS, 2003, p.471; GOMBRICH, 2007, p.290-291). Segundo José Marques de Melo,

Foi justamente na década de 1830 que surgiu na França o jornal $L a$ Caricature, publicando a imagem como desenhada, como complemento do registro verbal dos fatos da atualidade. No segundo caso, observamos que o recurso da caricatura representou uma necessidade social de um jornalismo que ampliava seu raio de ação, ganhando novos leitores. O novo público da imprensa continha segmentos que não haviam tido o privilégio da educação formal continuada e cuja percepção dos acontecimentos exigia processos descritivos mais eficazes e motivadores (MELO, 2003, p.164). 


\section{LES POIRES,

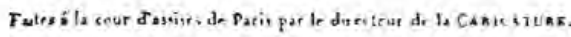

Vendues pour payer les $6,000 \mathrm{fr}$. d'amende du journal le Charivari.

(CHEZ ALBERT, GALERIE VERO-NONIT)

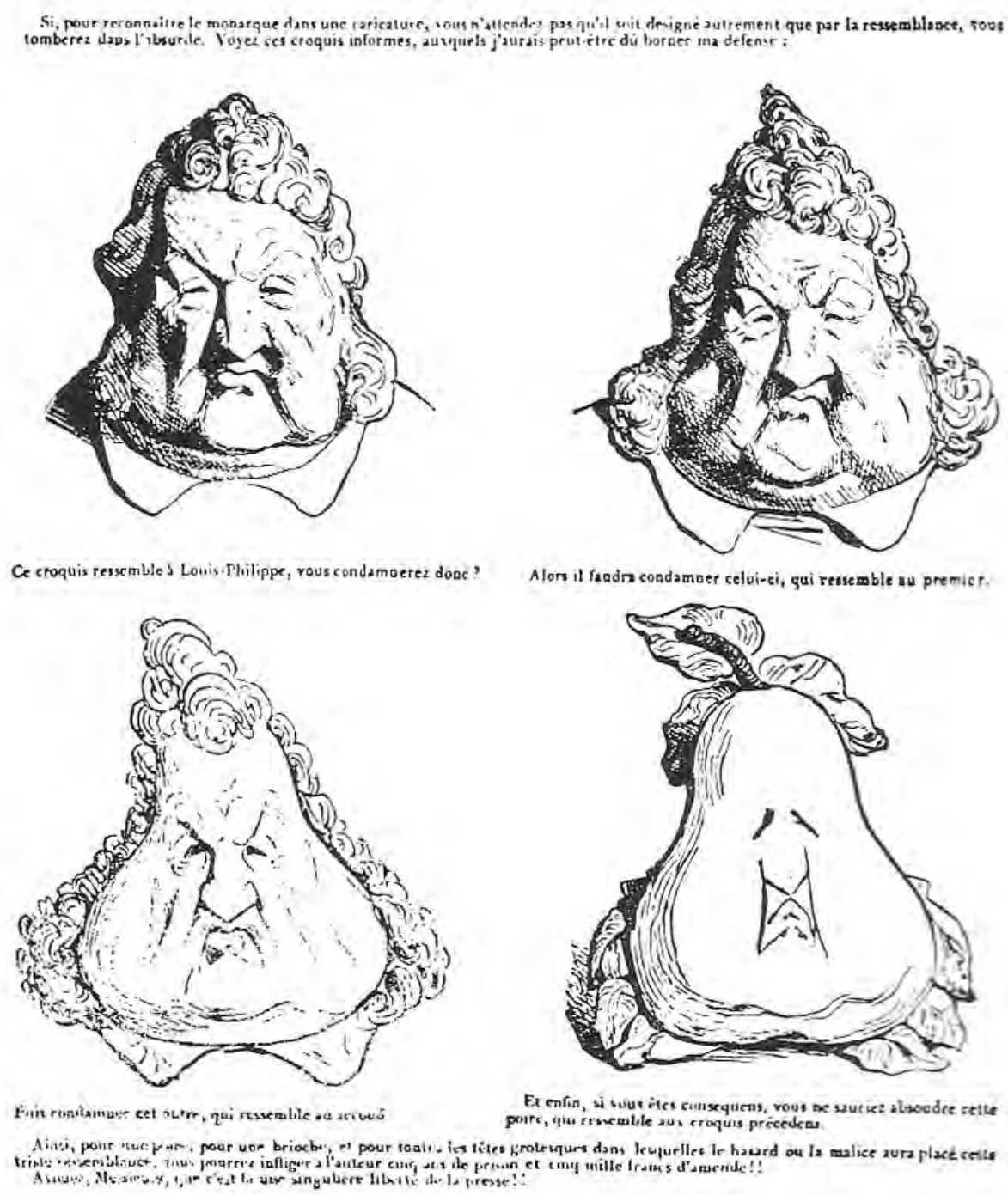

Figura 47 - Les poires, de Charles Philipon

Nesse contexto, tornaram-se célebres as caricaturas do Rei Luís Filipe, desenhado como uma pera, veiculadas jornal La Charivari (1834). Em francês, a palavra pera (poire) possui um dupla conotação, designando a fruta ou uma pessoa "palerma", "tola”, “imbecil”. Existem algumas dúvidas quanto à autoria dessas caricaturas, que são atribuídas tanto a Daumier, quanto ao editor do jornal e também 
caricaturista Charles Philipon. O certo é que, após ser condenado judicialmente pelas caricaturas subversivas, Philipon defendeu-se de forma brilhante: numa série de quatro desenhos, demonstrou a real semelhança entre o rei e a pera (Figura 47), tentando provar ironicamente que a "culpada era a natureza e não o autor das caricaturas" (SILVEIRA, 2009, p.30). Acerca dessa transformação fisionômica, Gombrich complementa:

$\mathrm{Na}$ verdade, sentimos que, a despeito da alteração de cada traço individual, o conjunto permanece notavelmente parecido. Aceitamos isso como uma maneira alternativa possível de ver o rosto do rei. Pois esse é o segredo de uma boa caricatura - oferecer uma interpretação visual de uma fisionomia que desde então não conseguimos esquecer e que a vítima sempre carregará consigo como um homem enfeitiçado (GOMBRICH, 2007, p.291-292).

Conforme se pode perceber por essa breve explanação, a caricatura é uma forma de criação gráfica cuja própria natureza está atrelada à construção de um modelo eficiente de representação da realidade visual. Por mais distorcida ou simplificada que seja a caricatura, ela perde sua razão de ser caso não consiga criar um vínculo com a pessoa retratada. Na sua atividade profissional, é comum que Angeli desenhe caricaturas que, surpreendentemente, não se preocupam em reproduzir a aparência física dos indivíduos. $\mathrm{O}$ autor aborda a caricatura de um forma muito particular, a partir do seu estilo gráfico cartunizado. Vejamos, por exemplo, uma caricatura do então presidente José Sarney publicadas na Chiclete com Banana $n^{\circ} 17$ (Figura 48). Caso essa imagem fosse retirada do contexto, dificilmente seria possível reconhecer que essa personagem cartunizada, de bigodes e sombrancelhas unidas é na verdade uma caricatura do presidente Sarney. É comum e bastante acertada a afirmação de que as charges só podem ser compreendidas dentro de um contexto específico, mas não deixa de ser curioso que uma caricatura dependa de dados exteriores à informação gráfica para que possa ser reconhecida. De fato, a configuração pictográfica dessa caricatura em nada difere da encontrada nas demais personagens de Angeli. Quanto mais se observa a obra de Angeli, em especial a executada durante o período em que a revista Chiclete com Banana esteve nas bancas, mais o autor parece preso a um estilo simples de cartum. Esse estilo gráfico é 
reproduzido em qualquer modalidade de expressão, seja a caricatura, narrativas ficcionais ou autobiografia.

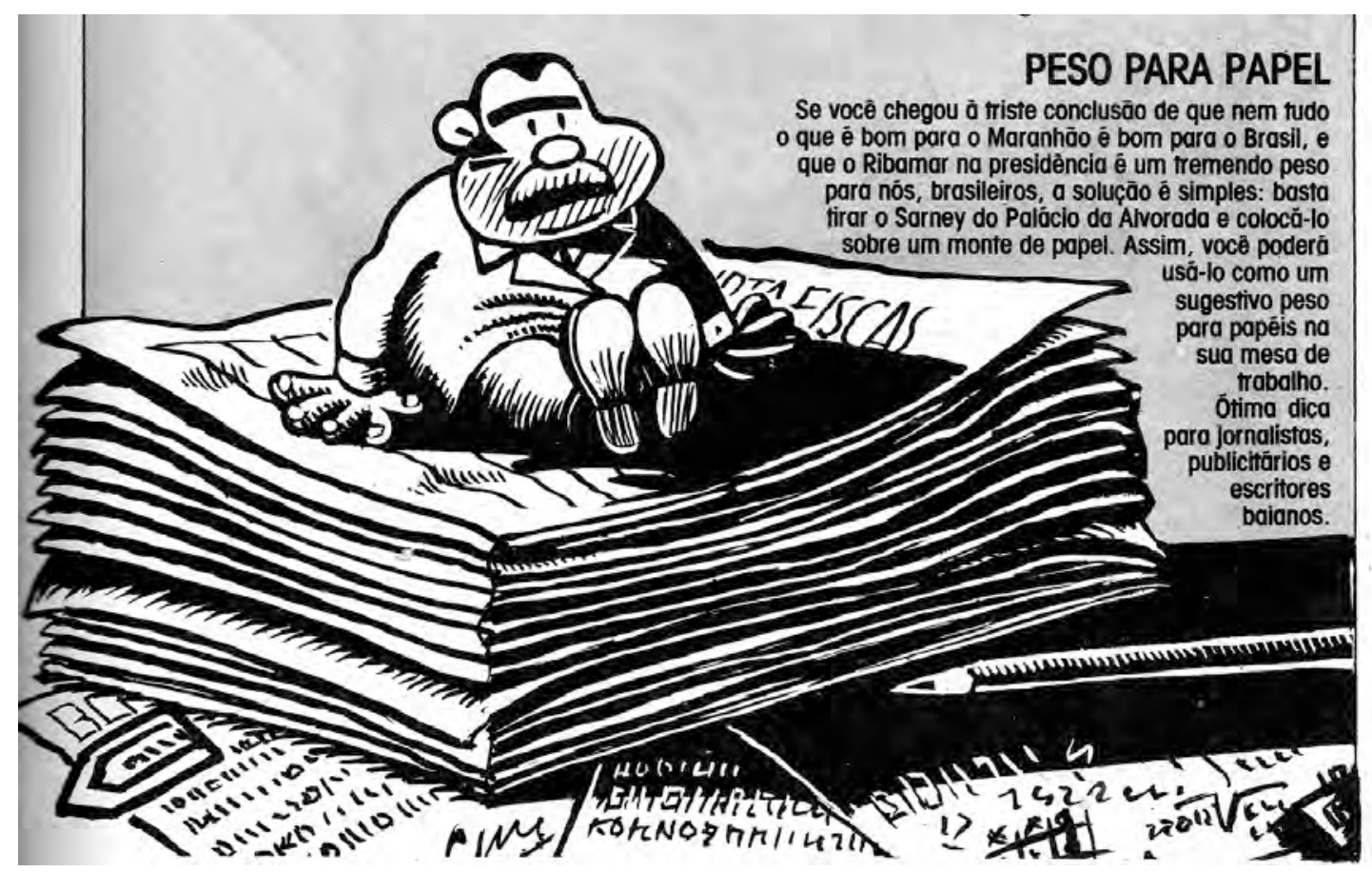

Figura 48 - Caricatura do presidente Sarney

Ao contrário da caricatura, o cartum é uma forma de criação gráfica completamente livre da necessidade de reproduzir minimamente a realidade visual, do que decorre o grande número de estilos diferentes que podem ser identificados como "cartunizados". O processo de cartunização pode ser descrito com uma simplificação das características de um objeto até suas unidades mínimas que, por sua vez, são convertidas a partir de uma schemata, as convenções definidas pelo trabalho acumulado dos artista e por cada artista individualmente. Assim, um olho pode ser convertido em um simples ponto, numa combinação de círculos, pontos e círculos, pontos e linhas, ou o que quer que seja. Em todos esses casos subsiste a afastamento com a aparência real do olho. Conforme Gombrich (2007, p.284), essa capacidade de “criar a ilusão de vida, sem qualquer ilusão de realidade" está associada aos efeitos pictóricos desenvolvidos na pintura e na "disposição de parte do público de aceitar o grotesco e o simplificado". Rudolphe Töpffer, precursor das histórias em quadrinhos, é apontado por Gombrich como o primeiro artista a desenvolver e sistematizar um estilo de cartunização. Na obra de Töpffer já é possível perceber a tentativa de 
sistematizar o modo como as expressões faciais podem ser simplificadas sem perder seu potencial informativo.

Töpffer busca aquilo que os psicólogos chamariam de "chaves mínimas" da expressão, às quais reagimos, quer as encontremos na realidade, quer na arte. Tentando descobrir o que acontece, não com o boneco de desenho, mas com ele mesmo, quando essas chaves são variadas sistematicamente, Töpffer as utiliza como um instrumento para sondar os segredos da percepção fisionômica (GOMBRICH, 2007, p.288).

Esse aspecto da percepção humana, que sempre tende a preencher uma imagem incompleta (ARNHEIM, 2000, p.47), possibilita a leitura da imagem cartunizada. Contudo, o vínculo dessa imagem com a realidade visual sempre permanece distante e indireto. No caso específico da autobiografia de Angeli, o estilo cartunizado funciona como um índice de reconhecimento bastante tênue. A imagem do autor, por exemplo, dificilmente pode ser reconhecida como um retrato, mesmo entre os leitores que reconhecem sua aparência (o que não acontece no caso dos autorretratos de Crumb). Inicialmente, a relação de identidade entre a representação cartunizada e a do autor é estabelecida pelo título Angeli em Crise. Após um certo período de publicação, esse vínculo se fortalece pela utilização recorrente dessa imagem. Outros aspectos da configuração pictográfica das histórias autobiográficas de Angeli também permanecem num nível de representação bastante vago. Essas narrativas são ambientadas na cidade de São Paulo, como se pode perceber pelo contexto, mas não são apresentados indícios que permitam fazer um reconhecimento efetivo. A cidade permanece como uma metrópole genérica, assim como bares, ruas e até mesmo o estúdio do autor.

Embora a utilização de um estilo cartunizado seja constante na obra de Angeli, existem diferenças significativas entre os seus primeiros trabalhos e os encontrados na série Chiclete com Banana. No início da carreira, os desenhos de Angeli eram mais soltos, com traços imprecisos, contornos maleáveis e sem hachuras, conforme se pode perceber por esse cartum publicado na Folha de S. Paulo em 18 de setembro de 1977 (Figura 49). De fato, esse imagem se assemelha mais ao trabalho de outros artistas brasileiros, como Henfil e Millôr, que propriamente ao estilo pelo 

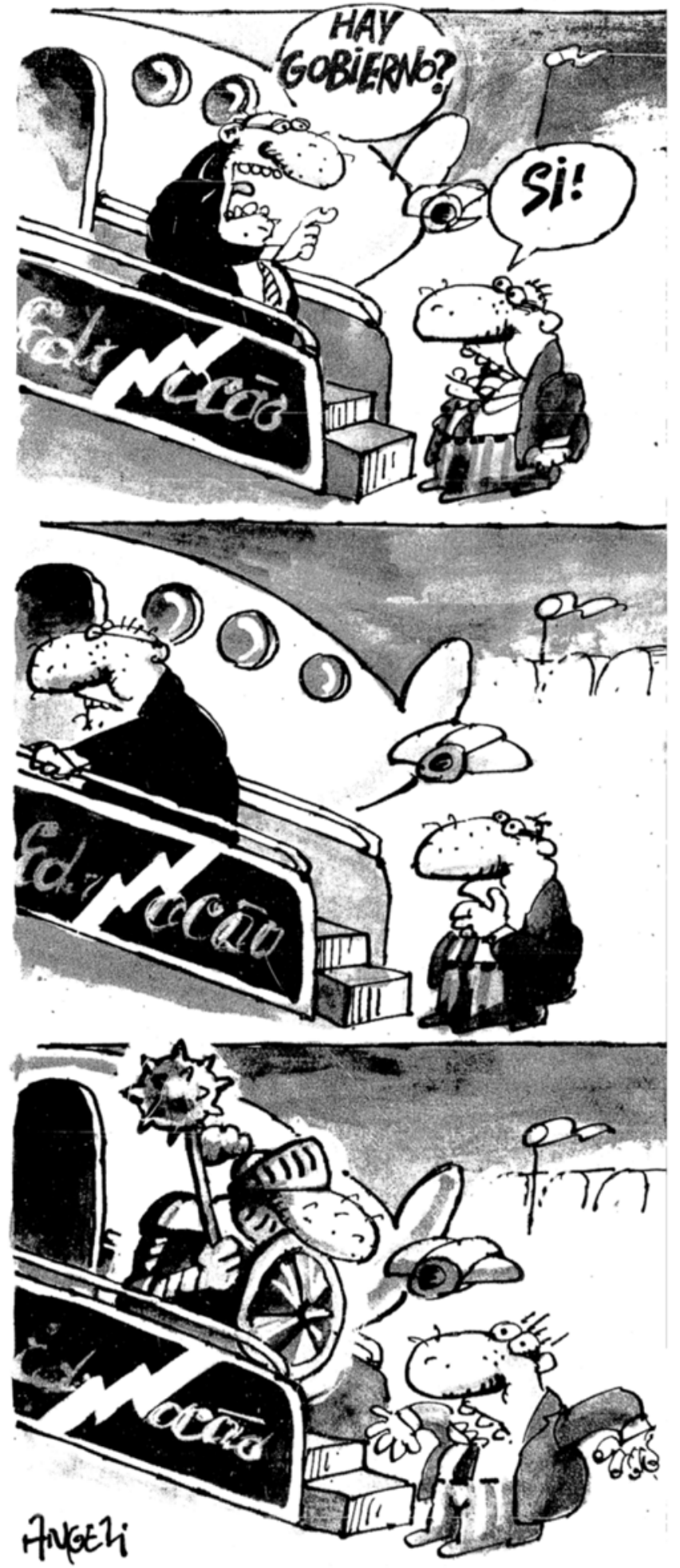

Figura 49 - Cartum de Angeli (1977)

qual Angeli ficou conhecido. Após o início da tira Chiclete com Banana, a configuração gráfica lentamente torna-se mais rígida. As silhuetas ganham definição, o traço torna-se mais uniforme, as formas mais arredondadas e inicia-se o uso de 
hachuras, provavelmente a maior influência de Crumb sobre seu estilo gráfico. Essa transformação ajuda a explicar porque o estilo de Angeli parece tão icônico e original. De início, o autor estava mais ligado à tradição gráfica do humor brasileiro que, desde o trabalho de artistas como Belmonte e J. Carlos no início do século XX, construiu uma identidade mais limpa, baseada quase que exclusivamente na expressividade da linha. Posteriormente, sob influência do trabalho de Crumb, que revisita o estilo gráfico hachurado encontrado na imprensa norte-americana durante a década de 1920, Angeli incorpora elementos novos elementos ao seu grafismo. Seu estilo é, portanto, fruto da mistura original de duas tradições gráfica diversas.

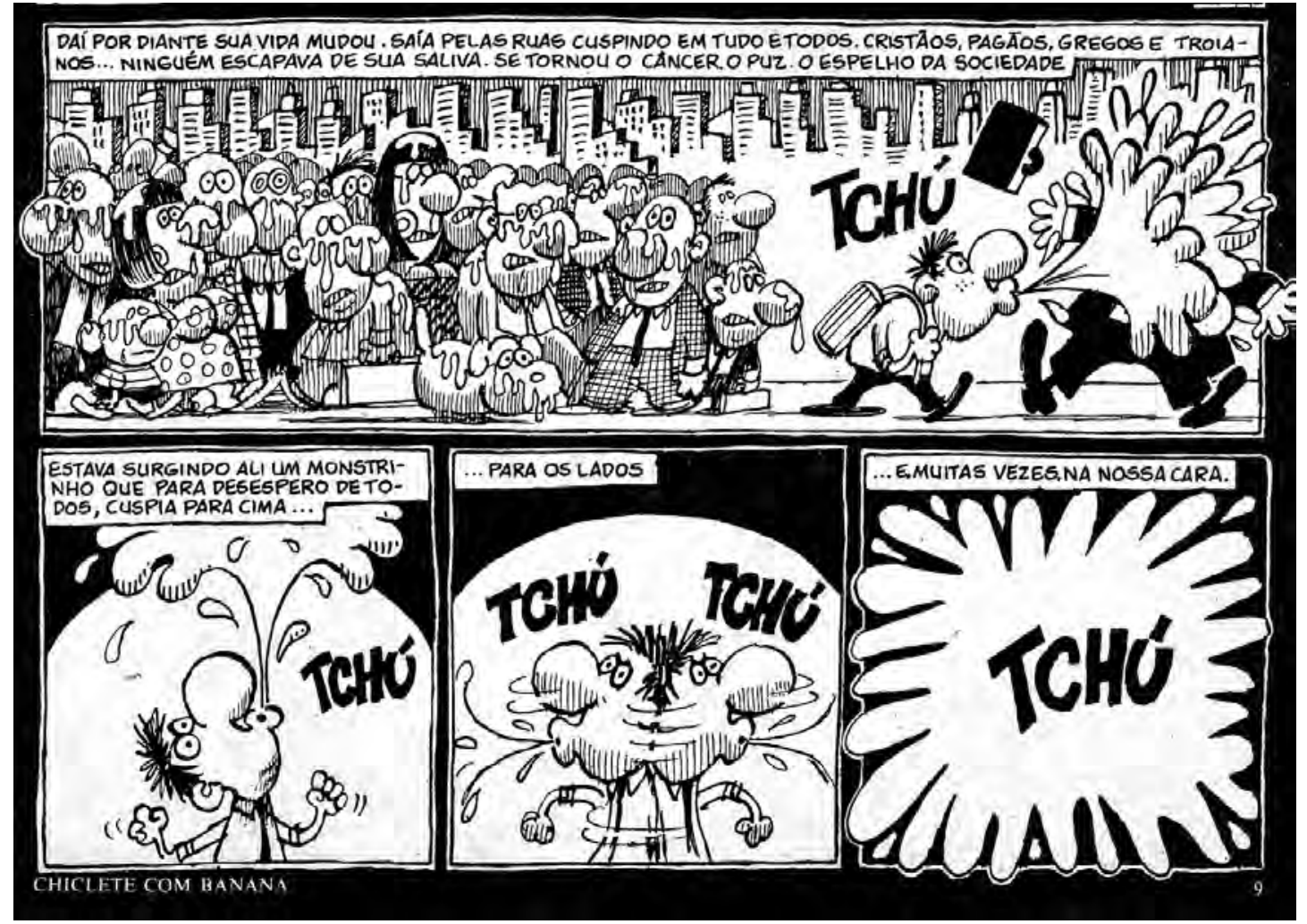

Figura 50 - Enquadramento nas primeiras obras de Angeli

No que se refere propriamente ao estilo das narrativas gráficas de Angeli, também podem ser apontadas diferenças consideráveis entre as tiras da série Chiclete com Banana e as histórias mais longas publicadas na revista. De início, podemos inferir que a tira diária, conforme desenvolvida no Brasil durante a década de 1980, não era um espaço que privilegiasse a experimentação gráfica. Disso decorre uma configuração gráfica muito estática, que tende à centralidade e onde as personagens são representadas seguindo o mesmo enquadramento em todas as vinhetas. Nas 
primeiras histórias da revista Chiclete com Banana (Figura 50), Angeli mantem essas características, utilizando apenas dois enquadramentos: plano médio (personagens de corpo inteiro) e meio primeiro plano (corte à altura do umbigo), os mesmos encontrados nas tiras. Conforme a produção dessas histórias curtas evoluem, Angeli começa a usar ângulos mais inusitados, com closes diversos e quadros mais amplos (Figura 51).
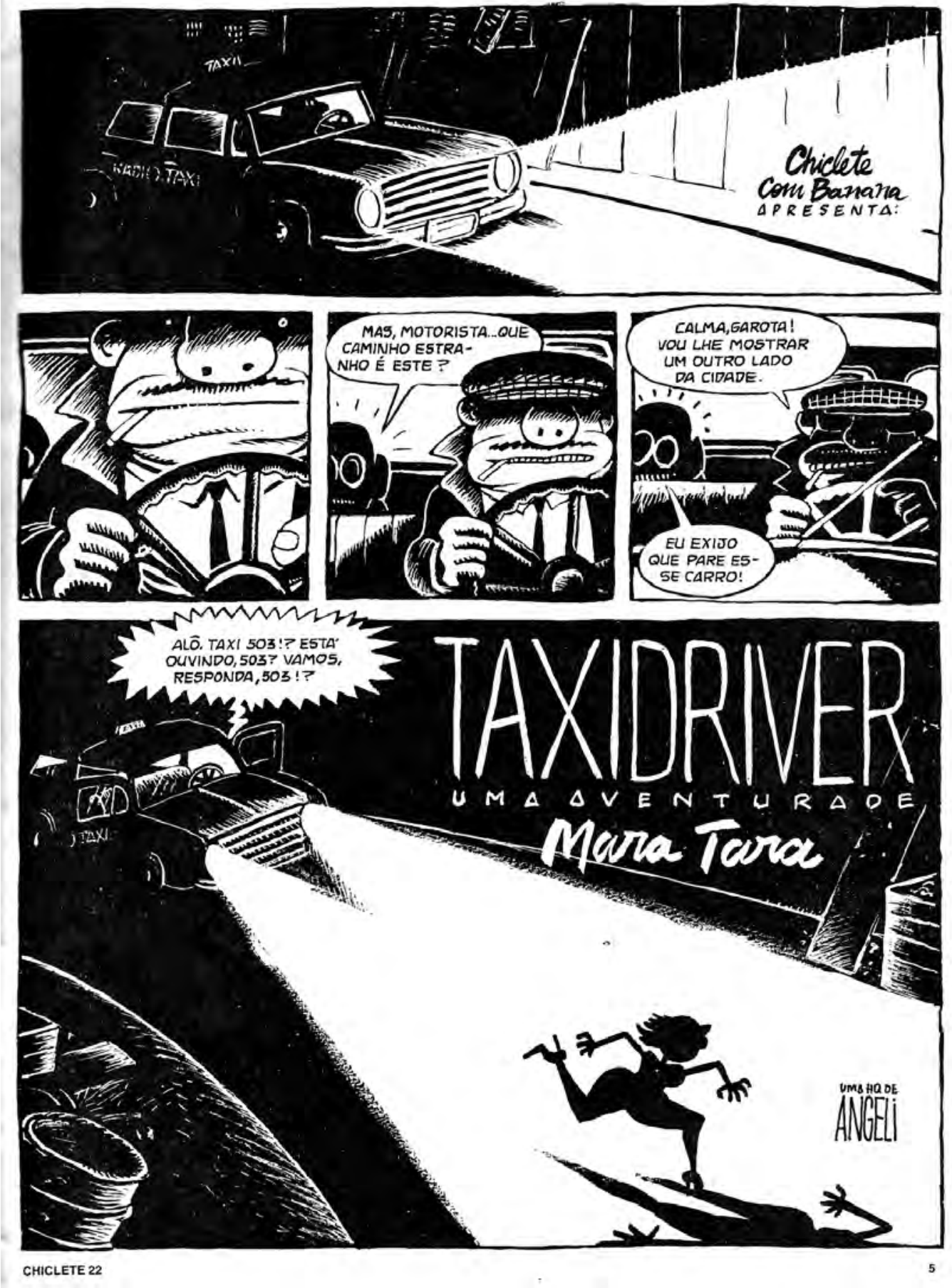

Figura 51 - Enquadramentos da fase final da Chiclete com Banana 
Um último aspecto dessa transição da tira para a revista Chiclete com Banana diz respeito à maior liberdade com que Angeli podia abordar temas sexuais. É certo que na Folha de S. Paulo já existia certa abertura, com cenas de nudez sendo representadas nas tiras nacionais. Em 10 de abril de 1984, a tira de Glauco já mostrava os seios da mãe do Geraldão e a personagem Rê Bordosa também exibia seus dotes em 21 de maio do mesmo ano. Aparentemente a Ilustrada era bastante livre no que diz respeito à representação do corpo feminino, já que até a tira do Pelezinho, de Mauricio de Sousa, mostrava uma moça nua em 7 de agosto. Contudo, na Chiclete com Banana, a abordagem das temáticas e imagens sexuais acontecia de maneira que seria impensável alguns anos antes: a revista trazia uma grande quantidade de fotografias de mulheres nuas, normalmente ilustrando a coluna do Edi Campana; Angeli e demais colaboradores reproduziam sem ressalva todos os detalhes anatômicos das personagens; e havia um grande número de imagens fortes nas histórias em quadrinhos, como relações sexuais explícitas, fetiches, estupros, orgias, escatologia e cenas de violências extrema. A brutalidade gráfica dessas imagens remete à produção dos comix mais extremos, como os do autor Victor Moscoso. Assim como aconteceu nos Estados Unidos na década de 1960, Angeli e os demais criadores brasileiros ligados à Circo Editorial buscavam ampliar as possibilidades formais da linguagem dos quadrinhos, extrapolando também o limite do bom senso. Contudo, no contexto brasileiro essas transgressões parecem mais subversivas, como se a sombra recente de repressão e censura oficial justificasse todas as grosserias. 


\subsection{0 cômico na narrativa autobiográfica}

Um aspecto que se destaca quando observamos os quadrinhos autobiográficos de Angeli, sejam tiras ou histórias mais longas, é a utilização recorrente do cômico como mote central da narrativa. No que se refere ao material publicado na Folha de S. Paulo, essa inclinação é justificada pelas imposições editoriais; afinal, durante a década de 1980 a Ilustrada publicava apenas tira cômicas. Essa proximidade da obra de Angeli com o humor, novamente, pode ser explicada a partir da sua atuação profissional como chargista e cartunista, atividades relacionadas diretamente com o humor desde a gênese das revistas ilustradas.

O século XIX foi aquele que viu nascer as revistas humorísticas, estimuladas pelos avanços nas técnicas de impressão e reprodução que possibilitaram o aumento das tiragens e o consequente aumento do público leitor. Esta associação entre humor e imprensa, especialmente destacada nos países europeus, também ocorreu nos principais centros urbanos brasileiros, embora tenham sido um pouco mais tardia, já que os processos de modernização da imprensa no Brasil foram mais lentos e concentravam-se nas três últimas décadas do século XIX (SALIBA, 2002, p. 38).

Do mesmo modo, o desenvolvimento das histórias em quadrinhos, da "literatura em estampas" até as primeiras séries americanas do início do século XX, foi marcado pela presença do humor (SANTOS, 2004, p.2). Além disso, as próprias necessidades narrativas do estilo de tira desenvolvido por Angeli também reforçam essa inclinação ao cômico, conforme esclarece Santos:

De maneira diferente dos quadrinhos editados em revistas e álbuns, as tiras cômicas - normalmente publicadas em jornais diários possuem uma estrutura diferenciada e uma narrativa que obedece a regras específicas. Se a tira de aventura precisa conter um "gancho" para que o leitor volte a procurar no dia seguinte a página de quadrinhos, a tira cômica é autocontida, pois apresenta uma piada (gag) que precisa ser contada em apenas algumas vinhetas (SANTOS, 2004, p.47). 

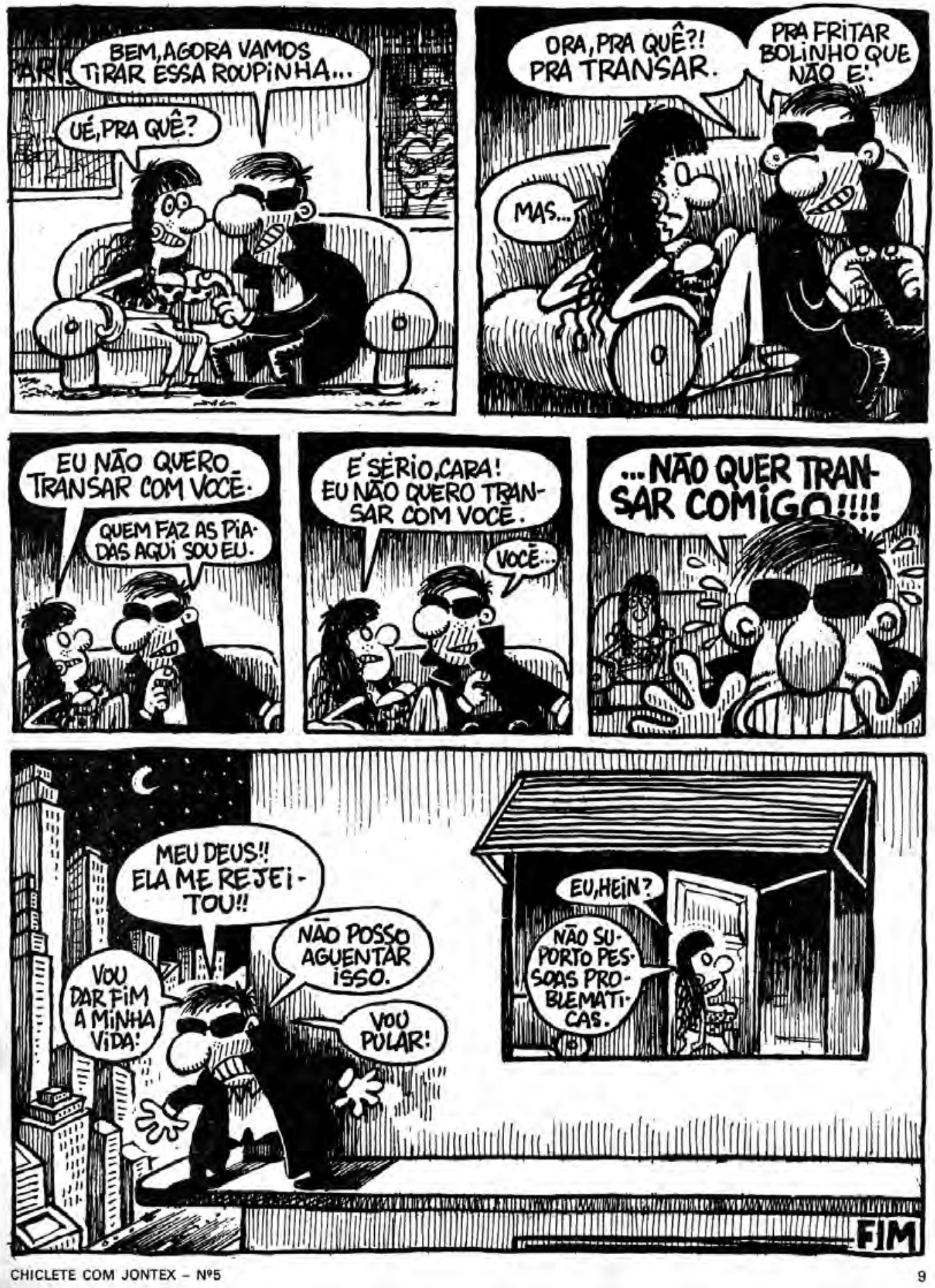

Figura 52 - Angeli em Crise

Quanto aos quadrinhos produzidos exclusivamente para a revista Chiclete com Banana, não existia essa amarra editorial em produzir narrativas de humor, já que publicação trazia frequentemente histórias de aventura (como "Entradas e Bandeiras", de Luiz Gê, publicada na edição 1), escatológicas (“Grande Merda”, de Marcatti, edição 7) ou experimentais ("Viagem ao centro do universo", de Luiz Gê, 
edição 23). Pode-se argumentar que os leitores da revista procuravam o mesmo estilo de humor que Angeli apresentava nos jornais, mas a abertura para tipos diferentes de narrativas permanece como uma possibilidade. De qualquer forma, o certo é que, quando Angeli faz histórias em quadrinhos de várias páginas, mantém-se apegado às convenções utilizadas na sua produção destinada à imprensa diária. Tanto que não identificamos, nos 24 números da Chiclete com Banana, não identificamos uma única história de sua autoria que não possa ser considerada como cômica. É interessante destacar que outros autores ligados à Circo Editorial, como Laerte e Luiz Gê, também produziam tiras cômicas para jornais e, mesmo assim, apresentavam um tipo de material mais experimental e sofisticado quando se aventuravam em histórias maiores.

Essa vinculação do trabalho de Angeli às diretrizes do estilo de humor encontrado em suas tiras é um aspecto importante para a compreensão de suas narrativas mais longas. Conforme já destacamos anteriormente, a impressão geral que essas histórias transmitem é de uma gag simples estendida artificialmente por um número inadequado de páginas. Vejamos, por exemplo, a primeiro quadrinho autobiográfico longo publicado na Chiclete com Banana. Essa história de cinco páginas (Figuras 43 e 52) tem um mote bastante simples: Angeli está bebendo num bar e é assediado por uma moça; inicialmente a rejeita mas acaba levando-a pra casa; quando propõe fazerem sexo a moça o rejeita, invertendo a situação e levando ao efeito cômico. Essa história poderia facilmente converter-se numa tira: no primeiro quadro, a moça o assedia e é rejeitada; no segundo ele acaba sendo convencido e propõe que façam sexo; e, no último quadro, ele é rejeitado e tenta se matar. A maior parte das histórias com mais de duas páginas produzidas por Angeli para a revista Chiclete com Banana seguem esse mesmo princípio. Contudo, o que aparentemente pode parecer uma inconsistência no trabalho do autor mostra-se muito eficiente quando percebido sob a ótica do humor. Dilatando a gag, o autor consegue construir de forma mais eficiente o clima adequado para o desfecho. Além disso, o decorrer da narrativa é permeado por pequenos chistes que tornam a leitura mais interessante.

A forma como Angeli consegue conduzir suas narrativas e atingir o objetivo de "fazer rir" decorrem de sua capacidade de mesclar habilmente categorias do cômico e do humor. Embora esses dois termos sejam comumente utilizados como sinônimos, existem diferenças significativas entre os dois. O cômico é uma categoria mais espontânea de riso que trabalha temas infantis, "baixos" ou grosseiros, como as 
funções excretoras, a mecânica sexual, a violência estilizada, defeitos e deformidades físicas e mentais, etc. Conforme Minois (2003), o cômico tem uma grande importância em processos sociais complexos, como o carnaval da Idade Média e as festas dos bobos do renascimento, além de fomentarem explosões esporádicas de subversão e escárnio contra as autoridades. Essa modalidade de riso espontâneo se modifica ao longo do história (MINOIS, 2003, p.194), passando de manifestações mais violentas e agressivas até o processo de domesticação iniciado no século XVIII. "Transformando-se em ironia e humor, o riso bruto perde a naturalidade, civiliza-se, intelectualiza-se e refina-se" (MINOIS, 2003, p.366).

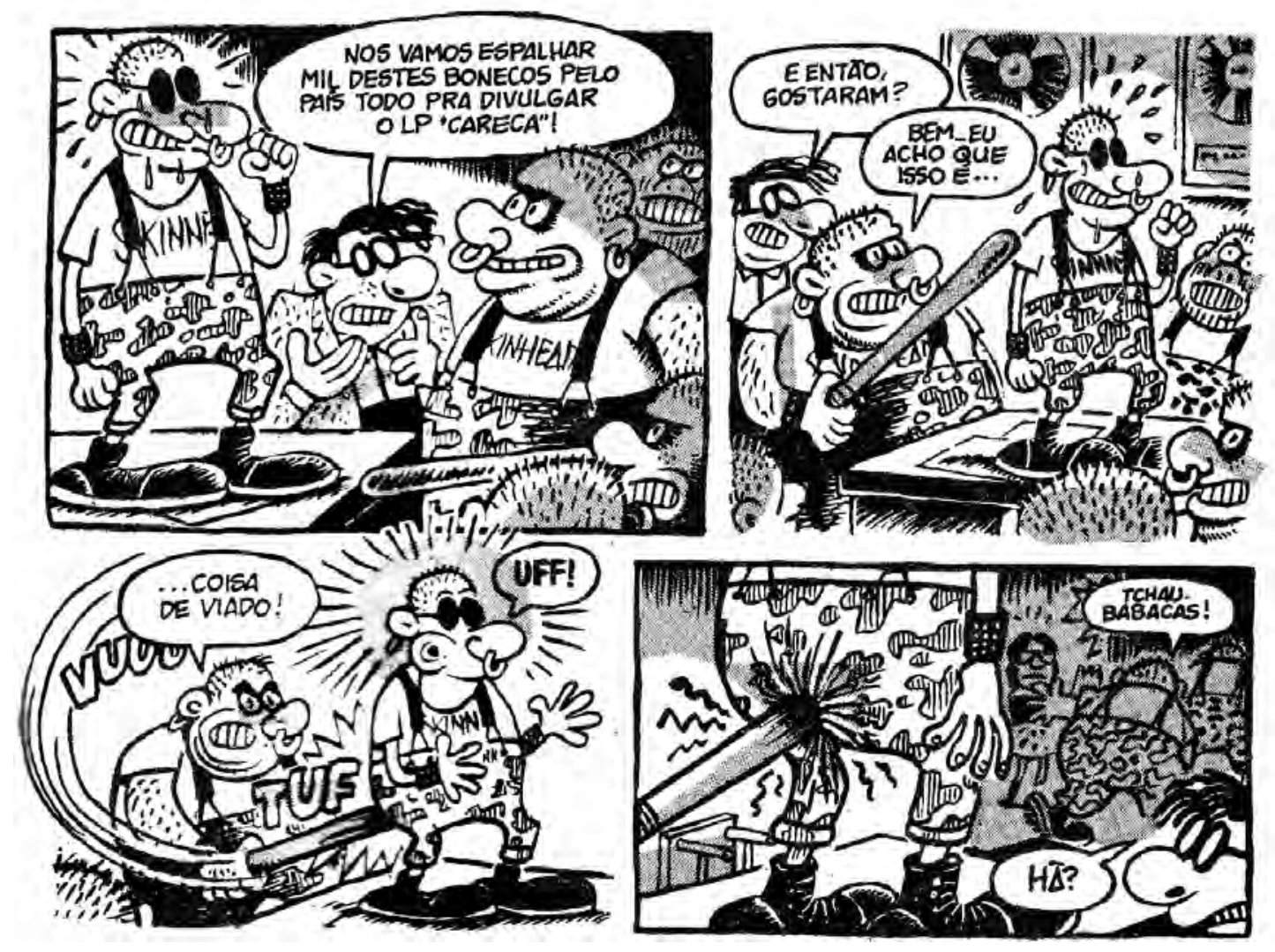

Figura 53 - Oliveira Junky

Nos quadrinhos de Angeli, a modalidade do cômico faz-se presente de modo pontual e bem dosado, na forma de alusões a funções excretoras, relações sexuais distorcidas e em figuras humanas nuas e, frequentemente, em situações ridículas e constrangedoras (Figura 53). Muitas vezes essas imagens cômicas são sobrepostas a chistes e piadas sofisticadas que se aproximam do tipo elaborado de riso encontrado no humorismo. Nesse ponto, as personagens de Angeli tornam-se risíveis pelos 
problemas inerentes à condição humana, sejam existenciais ou referentes à vida em sociedade. A oposição é clara: o humor se constitui como uma construção intelectual que se afasta do ridículo do corpo em função do ridículo da existência. Embora o humorismo seja uma modalidade que, de certa forma, pode ser mais facilmente identificável em torno de produtos culturais, como as comédias gregas ou as obras de Françoise Rabelais e Jonathan Swift, subsiste o estigma de uma modalidade de expressão inferior, como atesta a classificação do gêneros proposta por Aristóteles (1999, p.39). Conforme Minois,

O teatro antigo grego não hesita em misturar gêneros: comédias e tragédias alternam-se nas grandes competições. Nas leneanas (de lenai, ou bacantes, companheiras de Dioniso), a comédia aparece, pela primeira vez, em 440 a.C., e a tragédia, em 432 a.C. Mais revelador ainda: certos temas são tratados tanto como comédia quanto sob a forma de tragédia, como as leneanas e as danaides. Tragédia ou comédia humana? Às vezes basta deslocar ligeiramente o acento para passar de uma a outra. Os gregos antigos sabiam-no bem. Foi somente com a intelectualização crescente e a preocupação de classificação que os gêneros se apartaram pouco a pouco. Já para Aristóteles, é estrita a separação entre tragédia, que apresenta os homens como melhores do que são, e a comédia, que exagera seus defeitos (MINOIS, 2003, p. 37-38).

O estigma sobre o humor e o riso subsiste na contenda medieval e renascentista que especula acerca do riso de Jesus, bem como no espírito racionalista da Idade Clássica (MINOIS, 2003). Rir, historicamente, sempre se constituiu como uma atividade relacionada às classes inferiores, pessoas mais simples e "pobres de espírito" que não poderiam encarar a seriedade das grandes questões da existência. Apenas na virada do século XIXI para o século XX, com as obras de Henry Bergson, Sigmund Freud e Luigi Pirandello, a importância do humor como processo social e modalidade de expressão artísticas é destacada. Conforme Saliba

Foi também um momento histórico no qual a reflexão sobre o riso, revelando o desafio que impregnava toda a cultura fin-desiècle, transformou-se, a rigor, numa reflexão sobre a linguagem, sobre seus limites, suas funções cognitivas e sua destinação pública. Sintomas de uma crise da racionalidade cognitiva e, num aspecto mais extenso, das próprias formas subjetiva de representação, as concepções de Bergson, Freud e Pirandello não 
mais buscavam a "essência" do riso humorístico. Opondo-se aos "sistemas" e às grandes "teorias" do riso, as três concepções associaram o cômico ao inconsciente coletivo e revelaram, cada uma à sua maneira, o lado recôndito, obscuro e ambivalente do humor acabando, afinal, por relativizar e historicizar todas as inúmeras formas de representação humorística (SALIBA, 2002, p. 301-302).

Dentre esses três estudiosos do riso, Pirandello, também autor de peças de teatro que trabalham o humor, é provavelmente o que melhor descreveu a maneira como o humorismo pode constituir-se como uma modalidade de expressão artística séria. Pirandello inicia sua reflexão opondo-se à concepção em voga de que o humor seria uma manifestação tipicamente inglesa. $\mathrm{O}$ autor destaca a origem latina da palavra "humor", "corpo fluído, umidade ou vapor, e também com o sentido de fantasia, capricho ou vigor" (PIRANDELLO, 1999, p.44), que seria anterior ao humour inglês. Em seguida, Pirandello analisa a forma como diversos autores não necessariamente identificados como humorísticos, como Charles Dickens e Mark Twain, utilizavam de forma recorrente o humor em suas obras. Finalmente, Pirandello apresenta sua teoria sobre o humor, fundada na percepção do contrário.

Vejo uma velha senhora, com os cabelos retintos, untados de não se sabe qual pomada horrível, e depois toda ela torpemente pintada e vestida de roupas juvenis. Ponho-me a rir. Advirto que aquela velha senhora é o contrário do que uma velha senhora e respeitável senhora deveria ser. Assim posso, à primeira vista e superficialmente, deter-me nessa impressão cômica. O cômico é precisamente um advertimento do contrário. Mas se agora em mim intervém a reflexão e me sugere que aquela velha senhora não sente talvez nenhum prazer em vestir-se como um papagaio, mas que talvez sofra por isso e o faz somente porque se engana piamente e pensa que, assim vestida, escondendo as rugas e as cãs, consegue reter o amor do marido, muito mais moço do que ela, eis que já não posso mais rir disso como antes, porque precisamente a reflexão, trabalhando dentro de mim, me leva a ultrapassar aquela primeira advertência, ou antes, a entrar mais em seu interior: daquele primeiro advertimento do contrário ela me fez passar a esse sentimento do contrário. E aqui está toda a diferença entre cômico e o humorístico (PIRANDELLO, 1999, p.147). 
Esse já célebre exemplo da velha senhora, ao mesmo tempo em que reforça as diferenças entre o cômico e o humorístico, exemplifica o modo como o humor, escancarando o ridículo da condição humana, consegue ultrapassar o limites da diversão frugal e irrelevante.

Afastando-se do humorismo como categoria de expressão artística, o estudo de Freud se preocupa mais em determinar as relações entre o chiste e o funcionamento do inconsciente. Publicado originalmente em 1905, apenas cinco anos após a sistematização da teoria do inconsciente perpetrada em A interpretação dos sonhos, Os chistes e sua relação com o inconsciente parece um objeto um tanto deslocado dentro da obra de Freud. De fato, o autor nunca voltou ao tema, mas a série de histórias cômicas (muitas de origem judaica) presentes nesse volume retornam em obras posteriores para exemplificar os mecanismos pelos quais o inconsciente se insere na linguagem comum. A investigação principal que Freud desenvolve nesse volume diz respeito ao prazer advindo do ato de ouvir ou contar chistes e piadas. Sua hipótese central diz respeito à sensação de economia mental que o chistes proporcionam. Isto é, os chistes funcionam como um atalho que condensa uma série de processos mentais num único ato de compreensão súbita e o riso decorreria, justamente, dessa constatação. $\mathrm{O}$ autor também estabelece as bases entre o ato social do riso e o funcionamento da psique humana:

\begin{abstract}
Assim uma explicação uniforme é fornecida pelo fato de que uma pessoa nos parece cômica, em comparação com nós mesmos, se gasta energia demais em suas funções corporais e energia de menos em suas funções mentais; não se pode negar que em ambos os casos nosso riso exprime uma gratificante sensação de superioridade com relação à pessoa (que achamos cômica). Se a relação nos dois casos é revertida - se a despesa física da pessoa é considerada menor que a nossa ou se sua despesa mental é maior - não mais rimos e sim, somos possuídos de assombro e admiração (FREUD, 2006, p.183).
\end{abstract}

Bergson, por sua vez, amplia a noção do riso como "gesto social”. De início, o autor destaca que não existe "comicidade fora do que é propriamente humano" (BERGSON, 1983, p.12) e que riso ocorreria, justamente, quando identificamos em um ser humano alguma coisa de um comportamento mecânico (BERGSON, 1983, p.14). Conforme Saliba (2002, p.21), essa teoria do cômico, fundada na antítese entre 
elementos mecânicos e elementos vivos, é bastante influenciada pela forma como o recém-nascido cinema trabalhava a comédia física para despertar o riso nas audiências. Com efeito, Bergson utiliza como exemplo a queda de um transeunte, performance que se tornaria lugar-comum do cinema, para descrever essa relação entre orgânico e mecânico.

\begin{abstract}
Alguém, ao correr pela rua, tropeça e cai: os transeuntes riem. Não se riria dele, acho eu, caso se pudesse supor que de repente veio a vontade de sentar-se no chão. Ri-se porque a pessoa sentou-se sem querer. Não é, pois, a mudança brusca de atitude que causa o riso, mas o que há de involuntário na mudança, é o desajeitamento. Talvez houvesse uma pedra no caminho. Era preciso mudar o passo ou contornar o obstáculo. Mas por falta de agilidade, por desvio ou obstinação do corpo, por certo efeito de rigidez ou de velocidades adquiridas, os músculos continuaram realizando o mesmo movimento, quando as circunstâncias exigiam coisa diferente. Por isso a pessoa caiu, e disso é que os passantes riem (BERGSON, 1983, p.14).
\end{abstract}

A queda também exemplifica outro ponto central de sua teoria, a "insensibilidade que naturalmente acompanha o riso" (BERGSON, 1983, p.12). Ora, se por um momento o espectador do tombo se preocupa com o fato de que a pessoa possa ter se machucado, o riso imediatamente cede lugar a uma apreensão. Para Bergson, o riso "exige algo como certa anestesia momentânea do coração para produzir todo o seu efeito. Ele se destina à inteligência pura” (BERGSON, 1983, p.13). Esse aspecto cruel do riso seria responsável pelo seu aspecto de controle social.

Pelo temor que o riso inspira, reprime as excentricidades, mantém constantemente despertas e em contato mútuo certas atividades de ordem acessória que correriam o risco de isolar-se e adormecer; suaviza, enfim, tudo o que puder restar de rigidez mecânica na superfície do corpo social (BERGSON, 1983, p.19).

No que se refere ao tipo de humor encontrado na Chiclete com Banana e demais revistas publicadas pela Circo Editorial, Santos destaca que ele contraria a 
teoria elaborada por Bergson, já que não visa controlar o comportamento para adequá-los a normas ou condutas sociais, "mas pretende denunciar como ridículas as atitudes consideradas aceitáveis por uma sociedade que cultua a aparência, a hipocrisia e o consumismo alienado" (SANTOS, 2004, p. 61). Essa análise se aplica à maior parte da produção de Angeli, mas sua proximidade com movimentos contraculturais, particularmente o punk, permite uma leitura diferenciada. Angeli sempre teve uma tendência a criticar ideologias, tanto que criou a personagem Meiaoito como "uma gozação em cima dos comunistas ortodoxos" (ANGELI, 2008, p.205). O caso da gênese da personagem Bob Cuspe foi diferente, conforme relata o próprio autor:

Eu ainda estava um pouco contaminado pelo esquerdismo quando ganhei um livro do Antonio Bivar, "O Que É Punk". Eu olhei aquele livro e achei que era mais uma modinha importada. Joguei de lado. Fiz o Bob Cuspe para criticar os punks. Aí eu resolvi ler o livro e vi que punk era legal [...]. Comecei, então, a dar uma guinada no Bob Cuspe, para ele ser o herói da história, não o idiota. E a partir daí eu acho que minhas tiras começaram a ter uma pegada punk, porque eu comecei a me influenciar pelo punk, comecei a escutar coisas punk (ANGELI, 2008, p.205).

Essa proximidade de Angeli com o punk se reflete até mesmo na Uppercut, que trazia uma pequena seção intitulada Suburbanos, espaço onde os diversos grupos de punks e carecas debatiam questões diversas. Quando Angeli critica os modismos e as tribos urbanas pré-fabricadas acaba utilizando o punk como uma âncora, um tipo de subcultura que, na sua concepção, é realmente autêntica. Assim, estranhamente, em determinados casos o humor de Angeli não tenta controlar o comportamento em função de condutas sociais, mas, sim, a partir da ideologia específica do punk, que é, por definição, extremamente antissocial. Contudo, especificamente dentro da série Angeli em Crise, o estilo de humor que identificamos segue à risca as proposições da hipótese de Santos, já que o autor se engaja unicamente em uma autocrítica. Mesmo assim, elementos dessa influência punk se fazem presentes no mote das narrativas, na personalidade, no visual do autor/personagem e em alusões a um universo musical específico. A página do editorial da Chiclete com Banana ${ }^{\circ} 6$ exemplifica bem esse fenômeno (Figura 54). 

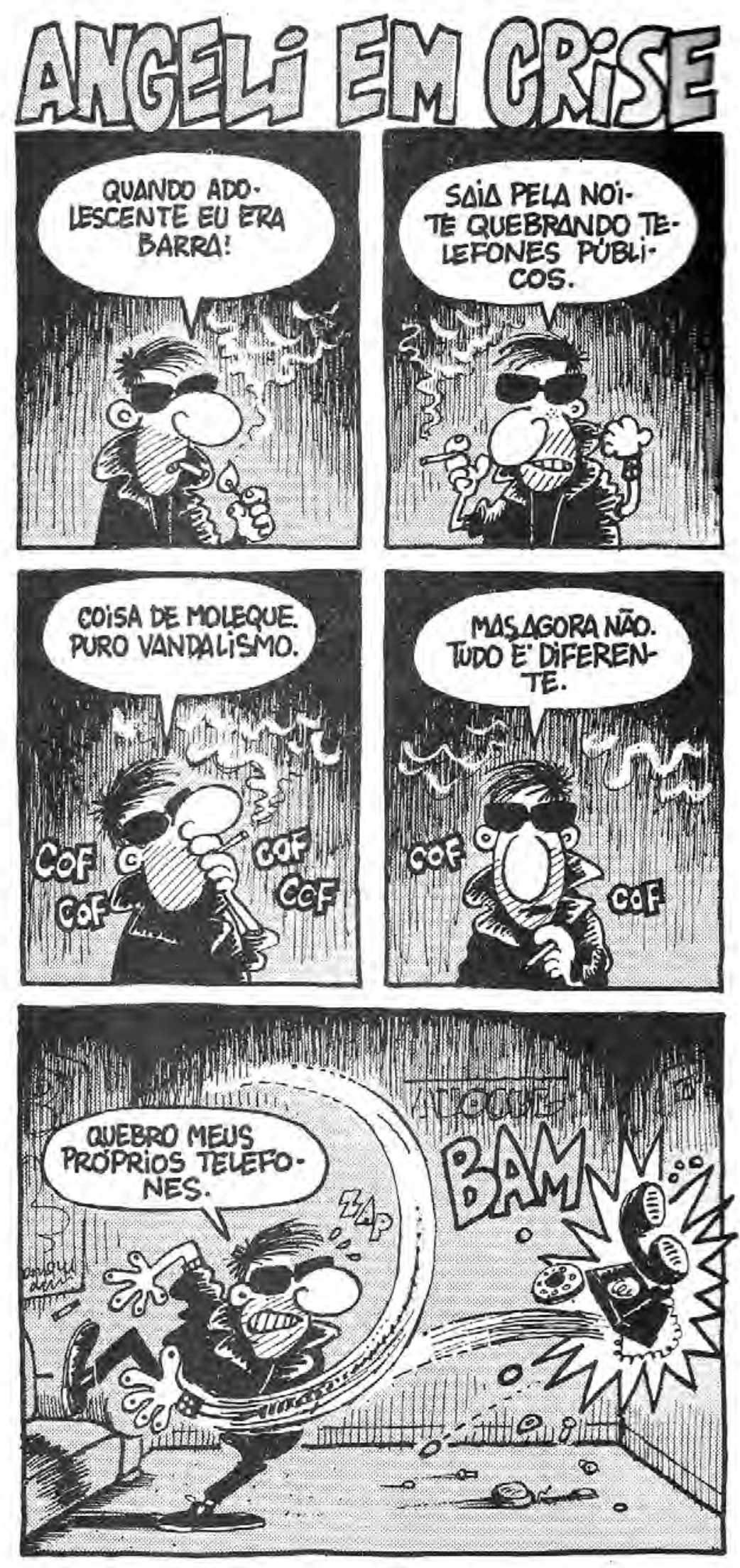

Figura 54 - Angeli em Crise 
A noção do humor como percepção do contrário, proposta por Pirandello, é provavelmente a teoria que consegue descrever com mais exatidão a obra de Angeli. Por um lado, suas tiras se baseiam nessa percepção, onde a graça advém justamente do fato de que as coisas não acontecem como deveriam. Em outro nível, as próprias personagens do autor são construídas em torno de contradições: Rê Bordosa é a mulher que se emancipou dos homens mas não consegue se resolver emocionalmente; Meiaoito é um revolucionário que perdeu o bonde da própria revolução; e Bibelô é o machão deslocado num mundo que exige mais sensibilidade do homem. A própria autorepresentação construída em Angeli em Crise também funda-se na contradição, nessa percepção do contrário: o autor que não consegue criar; ou, quando a crise ganha contornos mais existências, o homem moderno inseguro e acuado pela liberação feminina.

Além da inclinação ao cômico, outro aspecto que se destaca na série Angeli em Crise é que nenhuma história pode ser considerada como estritamente autobiográfica. Embora a relação de identidade e o pacto autobiográfico faça-se presente, essas narrativas não se utilizam da memória ou tentam remeter a acontecimentos reais da biografia do autor. Mesmo trabalhando com uma categoria que podemos considerar como "personalidade", boa parte das tramas poderiam ser protagonizadas por outras personagens, sem maiores perdas. Em muitos sentidos, Angeli em Crise é a simulação do modelo de autobiografia desenvolvido no Estados Unidos a partir da tradição dos quadrinhos de humor brasileiros. O autor não explora suas pulsões internas (como faz Crumb nas suas narrativas autoficcionais), se preocupando antes em construir um modelo de narrativa onde o cômico possa ser facilmente fruído. Assim, na obra autobiográfica, memória e comicidade parecem ser mutualmente excludentes. A piada é mais importante que qualquer projeto memorialístico e, em última análise, que qualquer semelhança com os acontecimentos. É interessante que quando autor se propõe a fazer experimentos autobiográficos em prosa - como, por exemplo, em "E Agora são Cinzas" e "Os broncos também amam" -, essa estrutura centrada no humor se desfaz. Esses enxertos configuram-se como autobiografias no sentido clássico, onde o autor aborda experiências reais de sua vida e problematiza como esses eventos contribuíram para a formação da sua personalidade.

Essa modalidade de escrita de si, centrada quase que exclusivamente no humor é a contribuição original de Angeli ao universo da autobiografia em 
quadrinhos, já que não encontramos dentro da matriz norte-americana equivalentes a esse estilo de tira cômica. Por considerarmos que o termo autoficcionalidade não dá conta da especificidade dessa manifestação, propomos a noção de autocomicidade para designa-la. A autocomicidade seria um tipo de escrita que mantém as relações de identidade entre autor e personagem mas, ao contrário da autoficção, não se preocupa em trabalhar de trabalhar as pulsões e fantasias do indivíduo; sua intenção é utilizarse dos dados biográficos e da personalidade do autor com a única finalidade de fazer graça. Esse conceito de autocomicidade pode ser mostrar útil para a análise de uma série de manifestações, como as comédias stand-up, os filmes de Wood Allen ou a obra jornalística de Hunter S. Thompson. No caso específico do estilo de autobiografia em quadrinhos desenvolvida no Brasil, primeiramente por Angeli e depois por autores como Laerte, Adão Iturrusgarai, Allan Sieber, Ricardo Coimbra e André Dahmer, a autocomicidade consegue descrever a forma como as relações de identidade e os dados biográficos são trabalhados como projeto humorístico. 


\section{CAPÍTULO V - A MATRIZ AUTOBIOGRÁFICA}

\subsection{Experiência e autocomicidade}

Em 1995, o diretor Terry Zwigoff lançou o documentário Crumb. Valendo-se de uma amizade de longa data, Zwigoff conseguiu adentrar profundamente na vida íntima e familiar do artista, pouco afeito a entrevistas e ao culto às celebridades (como se pode perceber na história autobiográfica R. Crumb, 'The Old Outsider', Goes To The Academy Awards). O filme constrói um retrato muito interessante, tematizando o método de trabalho, visão de mundo e a contraditória personalidade de Crumb. Em um dos momentos mais significativos, Crumb mostra seu ambiente de trabalho, um galpão com inúmeros objetos que colecionou durante a vida: quadrinhos antigos, discos, objetos de arte com alguma ligação com sua carreira, relíquias do início do século XX, brinquedos e uma grande diversidade de quinquilharias. Essa imagem é bastante significativa para entender o modo como Crumb desenvolve seus projetos autobiográficos, já que o seu passado e, em certo sentido, parte da memória da cultura norte-americana, está exposta permanentemente em seu estúdio/galpão. Durante a juventude, Crumb foi um colecionador compulsivo e a importância que ele dá a esses objetos pode ser dimensionada pelo fato dele tê-los levado quando se mudou para a França em 1991. O pesadelo logístico de transportar inúmeras caixas numa viagem transatlântica é a metáfora perfeita para descrever um homem que carrega consigo o passado e que dele não consegue se desvincular.

A autobiografia desenvolvida por Crumb, mesmo em suas modalidades mais delirantes e autoficcionais, é sempre mais retrato do que invenção. Seu método é semelhante ao do colecionador que revisita os objetos de seu arquivo: o autor elenca um tema ou um acontecimento específico de sua vida e constrói uma narrativa em torno dessa experiência. Parte dessas histórias baseia-se quase que exclusivamente na memória, engajando-se em reproduzir os eventos da forma mais ou menos fiel. Em outros momentos, Crumb utiliza-se de sua experiência interior. Pulsões, fantasias sexuais de dominação feminina, o desespero existencial, o ódio frente ao establishment e sentimentos de inadequação social assumem formas alegóricas nessas histórias em quadrinhos. Ou seja, embora as ações presentes nessas narrativas autoficcionais não correspondam a eventos vividos, elas reproduzem um certo tipo de 
experiência psicologicamente real. Nesse ponto, o conceito de autoficcionalidade mostra-se bastante útil para descrever essa dualidade entre vida interior $\mathrm{e}$ ficcionalizacão. Conforme Eneida Maria de Souza, a autoficção "teve o mérito não só de rever a relação complexa entre ficção e realidade, como de reforçar a incapacidade do sujeito de se manter íntegro e onipotente" (2011, p.21-22). O modelo de autobiografia episódica perpetrado por Crumb denota, justamente, essa personalidade fragmentada, que se define e se contradiz com a mesma facilidade. Acerca da veracidade dessas narrativas, Souza esclarece:

$\mathrm{O}$ autor tem a liberdade de utilizar o mesmo nome para sua personagem ou narrador, sem que tal gesto interfira no grau de fidelidade/infidelidade narrativa, em posição distinta daquela defendida por Phillippe Lejeune quanto ao pacto autobiográfico. Essa estratégia referencial às avessas reveste-se ainda da antiga poética narrativa, marcada pelo gesto de "mentir-vrai", "mentirverdadeiramente", operação que reúne princípios enunciativos ligados ao teatro e ao romance, construindo uma cenografia da enunciação. A desestabilização do referencial produz, com efeito, a invenção e a estetização da memória, esta não mais subordinada à prova de veracidade (SOUZA, 2011, p.23).

Essa noção de veracidade mediada da autobiografia também é formulada, em outros termos, por Gay, quando afirma "que as distorções inconscientes dos autobiógrafos ou suas falsidades deliberadas são partes da verdade, a verdade da autobiografia - não simples obstáculos, porém indícios de importantes realidades interiores" (1999, p.121). Assim, as fantasias elaboradas que identificamos em histórias como R. Crumb Versus The Sisterhood ou If I Were a King conseguem delinear a personalidade do artista de forma tão eficiente quando histórias propriamente autobiográficas, como My troubles with Women ou Memories are Made of This. A vida interior e os eventos cotidianos se complementam e delineiam um mesmo retrato complexo e multifacetado: o artista extremamente comprometido com o trabalho mas que não consegue levar a sério os quadrinhos como forma de expressão; o conquistador desajeitado, tímido e adulador que maltrata e se aproveita das mulheres em qualquer oportunidade; o dissoluto lascivo que não se desprende do complexo de culpa oriundo da criação católica; o ícone da contracultura dos anos 1960 que detesta hippies. Independentemente do grau de ficcionalização dessas 
narrativas, a tentativa de autodefinição permanece, bem como o "resíduo" da experiência concreta, conforme esclarece Manuel Alberca:

La autoficcón se presenta como una historia autobiográfica con tanta transparencia y claridad que el lector puede sospechar que se trata de una pseudo-autobiografía, o lo que es lo mismo, que aquel relato tiene "gato encerrado". Su transparencia autobiográfica proviene de la identidad nominal, explícita, del narrador y/o protagonista con el autor de la obra, cuya firma preside la portada (ALBERCA, 2013, p. 37).

No que se refere às contrapartes literárias de autoficção, Souza (2011, p.1922) destaca que elas se constituem principalmente como uma aventura teórica, levada a cabo em obras como Roland Barthes por Roland Barthes (1975) e Fills, de Serge Doubrovsky (1977). Esses exercícios intelectuais que tematizam concepções diversas, como as teorias psicanalíticas ou o conceito de "cuidado de si" formulado por Michel Foucault, contrastam vividamente como o modelo de autoficcionalidade espontânea e intuitiva desenvolvida por Crumb. Contudo, não deixa de ser curioso que todos esses projetos tenham surgido na segunda metade da década de 1970, período em que se renovou o interesse pela autobiografia (SOUZA, 2011, p.21).

Em Malditos Cartunistas, um documentário de 2011, também é possível ter uma visão do ambiente de trabalho de Angeli. O filme, dirigido por Daniel Garcia e Daniel Paiva, compila depoimentos de cartunistas de diversas gerações, como Jaguar, Ziraldo, Laerte, Adão Iturrusgarai, André Dahmer e Daniel Lafayette. Nesse importante registro do humor gráfico brasileiro, Angeli ocupa um lugar de destaque. Toda a sua participação foi registrada em seu estúdio, um ambiente bem mais convencional que o estranho galpão de Robert Crumb. O estúdio de Angeli é bastante funcional, com gabinetes de escritório que guardam os originais, alguns pôsteres com seu trabalho nas paredes, pilhas de livros avulsas e uma grande prancheta regiamente abastecida com materiais artísticos. Chama atenção também alguns recortes de jornais e revistas com matérias sobre o autor. Esses recortes formam um mosaico peculiar, em que pequenos retratos perscrutam o seu outro que trabalha na prancheta. De modo geral, podemos afirmar que esse é um ambiente de trabalho por excelência, tanto que corresponde perfeitamente à imagem mental que o senso comum faz do 
estúdio de um cartunista. Assim como ocorre no caso de Crumb, o ambiente de trabalho de Angeli é revelador quando ao modelo de autobiografia desenvolvido por ele.

Angeli é um autor que está inserido numa rotina produtiva bastante semelhante à pratica jornalística. Todos os dias é preciso produzir uma nova tira, além das charges e ilustrações editoriais ocasionais. Essa rotina é, ao mesmo tempo, responsável pela imensa produtividade e pela sedimentação do seu estilo. O ritmo de produção inibe o experimentalismo e impede que as narrativas autobiográficas da série Angeli em Crise possam ser desenvolvidas de forma diversa da sua produção propriamente ficcional. Nesse ponto, o conceito de autocomicidade mostra-se bastante adequado para descrever uma modalidade de narrativa de si que, a priori, está destinada a se constituir enquanto uma tira ou história em quadrinhos cômica. Não é incomum encontrar nas autobiografias em quadrinhos indícios de humor autodepreciativo. Crumb constantemente relembra o leitor de que não deve levar aquelas narrativas a sério, já que o próprio autor não se tem em alta conta. Contudo, a autocomicidade diverge bastante desse estilo de mock-autobiography (HATFIELD, 2005, p.x). Conforme Charles Hatfield:

Regarding autobiographical comics, hindsight reveals an ironic, self-reflexive impulse at work in many of the genre's urtexts. The ironies may not always be as bald, or as cynical, as in the key instances from our previous chapter, but nonetheless they are crucial, often contributing to a sense of distance between the "naïve" self depicted in the autobiography and the older, more sophisticated self responsible for the depiction (HATFIELD, 2005, p.128).

Hatfield complementa ainda que a ironia contribui para a autenticidade do relato, já que a perspectiva dual do autor que expõe sua vida e, ao mesmo tempo, ironiza esse relato constitui-se como uma "authentication through artifice, or more simply ironic authentication: the implicit reinforcement of the truth claims through their explicit rejection" (2005, p.125). Para além da questão da autenticidade do relato, o humor, autodepreciativo ou não, é fundamentalmente um recurso estilístico. Analisados objetivamente, os acontecimentos da vida cotidiana de qualquer pessoa não podem ser considerados como cômicos ou trágicos. O humor, como nos lembra 
Minois (2003, p.37), é um questão de tom, de acento. Assim, nas narrativas autobiográficas ou autoficcionais, os eventos externos ou "vida interior" podem ser tratados com o intuito de alcançar de efeitos cômicos. Na autocomicidade acontece o processo inverso já que, a priori, essas narrativas devem ser humorísticas, não prescindindo de qualquer relação com experiências reais. Nesse sentido, a autocomicidade baseia-se unicamente em um aspecto da realidade exterior: a personalidade do artista.

A série Angeli em Crise demonstra de forma exemplar esse desapego a eventos e experiências reais. Essas narrativas concentram-se exclusivamente na gag, no mote cômico, negando inclusive a realidade psicológica do autor/personagem. Se consideramos que a autobiografia foi uma das modalidades de expressão que acrescentou sutileza e profundidade psicológica aos quadrinhos, chama atenção que nessas narrativas autocômicas a personagem Angeli se mantenha tão plana, mais próxima de seus criações ficcionais que da persona real do autor. Com exceção das histórias longas "E que tudo mais vá pro inferno" e "As Sete Libélulas", que constituem-se em exercícios de autoficção, não é possível encontrar indícios que apontem para uma a tentativa concreta de construir uma "escrita de si" em sua obra. Assim, podemos afirmar que a autoficção se baseia em um "pacto ambíguo" (ALBERCA, 2013, p. 23), em algum ponto entre a modalidade autobiográfica (ou autoficcional) e os exercícios metalinguísticos.

O formato da tira diária mostrou-se bastante propício para essas narrativas autocômicas, já que seu caráter breve e episódico permite abordar pequenos motes sem nunca se aprofundar realmente na vida do autor. Além disso, o estilo de humor presente na série Angeli em Crise adequa-se perfeitamente à estrutura repetitiva da tira cômica. Conforme Santos:

A graça [da tira cômica diária] advém da engenhosidade do autor de repetir a mesma situação, mas de maneira diferente. O que leva o leitor a rir não é o que faz o personagem ou o que ele fala, mas a maneira nova como o autor vai fazer a personagem repetir o gesto cômico ou a fala engraçada (SANTOS, 2004, p.50).

Além disso, esses quadrinhos autocômicos de Angeli estão integrados à tradição do humor gráfico brasileiro. Enquanto em outros países a tira se desenvolveu 
em formatos diversos, apresentando histórias de aventuras com continuidade (como Dick Tracy, Terry and the Pirates, etc), no Brasil a popularidade da tira está diretamente ligada ao humor, embora algumas tentativas de emular esse formato de tira de aventura tenham sido levadas a cabo, sem muito sucesso. Esse caráter proeminente da tira cômica no Brasil é tão marcante que Paulo Ramos (2010, p.11) cunhou o termo "tiras livres" para designar a produção mais livre e experimental de quadrinhistas como Laerte. Conforme Ramos:

Outro gênero de tira que ganhou força no Brasil na primeira década desse século e foi bastante influenciado por trabalhos de Laerte Coutinho na série Piratas do Tietê, publicados na Folha de São Paulo. O diferencial dessas tiras é que elas se pautam numa liberdade temática, na ausência do humor e em tentativas nítidas de experimentação gráfica. Por isso, distinguem-se dos demais e se consolidam num gênero novo, autônomo, peculiar da produção nacional de histórias em quadrinhos. Por se centrar na liberdade de produção, propusemos, em artigo sobre o assunto, que o termo tira livre fosse o mais apropriado para se referir ao novo gênero (RAMOS, 2011, p.96).

Ainda segundo Ramos (2011), existe uma relação direta entre o estilo de tiras desenvolvido pelos artistas brasileiros e a piada. Essa proximidade pode ser identificada na série Angeli em Crise, cujas gags e pequenos motes cômicos poderiam facilmente ser convertidos em piadas, aforismos irônicos ou ditos espirituosos. Em certo sentido, Angeli faz piadas sobre si mesmo da mesma forma como algumas pessoas se auto ironizam na conversação cotidiana.

Tanto o modelo de narrativa autobiográfica/autoficcional encontrado na obra de Crumb, quanto o estilo de autocomicidade desenvolvido por Angeli ocupam um lugar central em suas respectivas matrizes autobiográficas. A partir da obra desses dois autores é possível identificar uma dispersão de quadrinhistas que revisitam seu estilo e convenções narrativas. Na matriz autobiográfica norte-americana que, na nossa leitura, engloba também os quadrinhos alternativos de língua inglesa produzidos no Canadá por artistas como Chester Brown, Seth (pseudônimo de Gregory Gallant) e Joe Matt, identificamos movimentos antagônicos que apontam, ao mesmo tempo, para um tipo mais intimista de autobiografia e para histórias mais 
preocupadas com a relação do indivíduo com a realidade histórica e social que o cerca. Essa segunda categoria pode ser exemplificada pelo modelo de biografismo desenvolvido por Art Spiegelman em Maus e pelas reportagens em quadrinhos de Joe Sacco, das quais trataremos no próximo tópico. Não é incomum que um mesmo quadrinhista circule livremente por essas duas tendências, mas encontramos os melhores exemplos da vertente mais intimista da autobiografia na obra de Harvey Pekar, Chester Brown e Alison Bechdel. Ao contrário de Crumb e Angeli, esses autores praticam a autobiografia como modalidade preferencial de expressão, construindo histórias que valorizam o cotidiano e a experiência interior do indivíduo, muitas vezes abordando temas dolorosos ou constrangedores. Na obra de Pekar, em grande parte publicada na sua revista independente American Splendor (posteriormente compiladas no livro American Splendor - The life and Times of Harvey Pekar, publicado pela Ballantine Books em 2003), encontramos um modelo de autobiografia baseada nas experiências mais banais do cotidiano, como o hábito de colecionar discos (Hustlin' Sides, desenhada por Robert Crumb), um sonho angustiante (Working man's nightmare, desenhada por Gerry Shawray), uma convocação para ser jurado (Jury Duty, desenhada por S. Cavey) ou esperar na fila do supermercado (Standind Behind Old Jewish Ladies in Supermarket Lines, também desenhada por Crumb). Frequentemente as histórias de Pekar são apenas longos monólogos acerca de questões que lhe afligem, uma exposição sincera da sua psique e personalidade. Conforme Witek:

Pekar too sometimes writes stories in which an autobiographical persona addresses the reader, but when Crumb cannot resist transforming his personal stories into self-parodies and shameless fantasies, Pekar's commitment to straightforward candor and direct rendering of experience keeps his stories serious in tone and realistic in style (WITEK, 1989, p.129).

Brown, por sua vez, construiu um estilo extremamente particular e contraditório de autobiografia, que relata da forma mais fria e objetiva possível os eventos mais íntimos e constrangedores da sua vida. Em The Playboy (1992), o autor relembra sua adolescência, detalhando suas práticas masturbatórias e o hábito de colecionar revistas masculinas. I never like you (1994) é relato detalhado da sua 
infância, concentrada principalmente nas suas primeiras paixões juvenis e no seu relacionamento com sua mãe, diagnosticada como esquizofrênica. Em seu trabalho mais recente, Paying for It (2011), Brown expõe sua decisão de evitar relacionamentos românticos, construindo uma espécie de relatório sobre todas as garotas de programa com que se relacionou. Como se pode perceber, todos os temas tratados são bastante íntimos, o que contrasta com a abordagem distanciada que Brown impõe a suas narrativas autobiográficas. O autor tenta expor apenas os fatos, a realidade externa dos acontecimentos. Mesmo assim, o leitor tem acesso aos complexos processos psicológicos e emocionais que acompanham o relato. Essa abordagem distanciada corrobora, inclusive, para compor um panorama da personalidade do artista, sempre muito frio e racional, características s até mesmo nas suas expressões faciais indiferentes e estáticas (Figura 55).

Finalmente, Bechdel é a autora que leva a autobiografia em quadrinhos para um novo nível de intimidade, explorando principalmente as nuances de suas experiências emocionais e vida interior. Em Fun Home (2006), a autora aborda seu relacionamento com o pai, detalhando como sua percepção dele como homem gay contribuiu para sua própria identificação como lésbica. Em Are You My Mother, seu livro mais recente, publicado em 2011, a artista volta-se para sua relação conturbada com a mãe. Esse livro é, provavelmente, a autobiografia em quadrinhos que melhor tematiza o mote da autodefinição. Ao contrário de Crumb, Pekar e Brown, Bechdel apresenta um tipo de narrativa bem pouco palatável. Influenciada principalmente pelas teorias psicanalíticas, a autora expõe de forma fragmentada pequenos incidentes da infância, seus relacionamentos, a descoberta da sua sexualidade, sonhos, sessões com diversos analistas e suas próprias investigações no campo da psicologia infantil. O relato é, fundamentalmente, sua jornada de autodescoberta, abordada num nível de detalhamento que dificulta o envolvimento do leitor. 

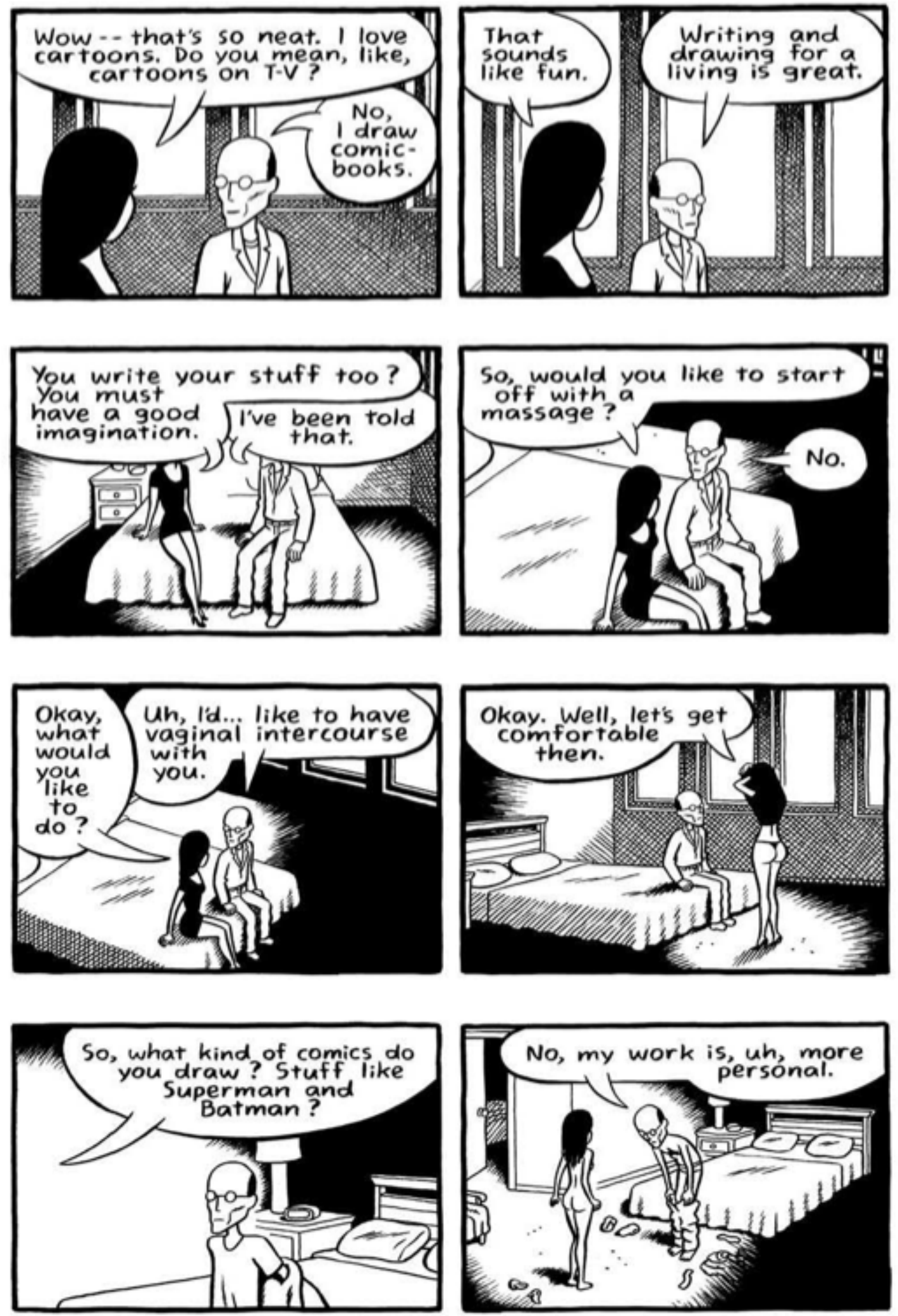

Figura 55 - Paying for it, de Chester Brown 


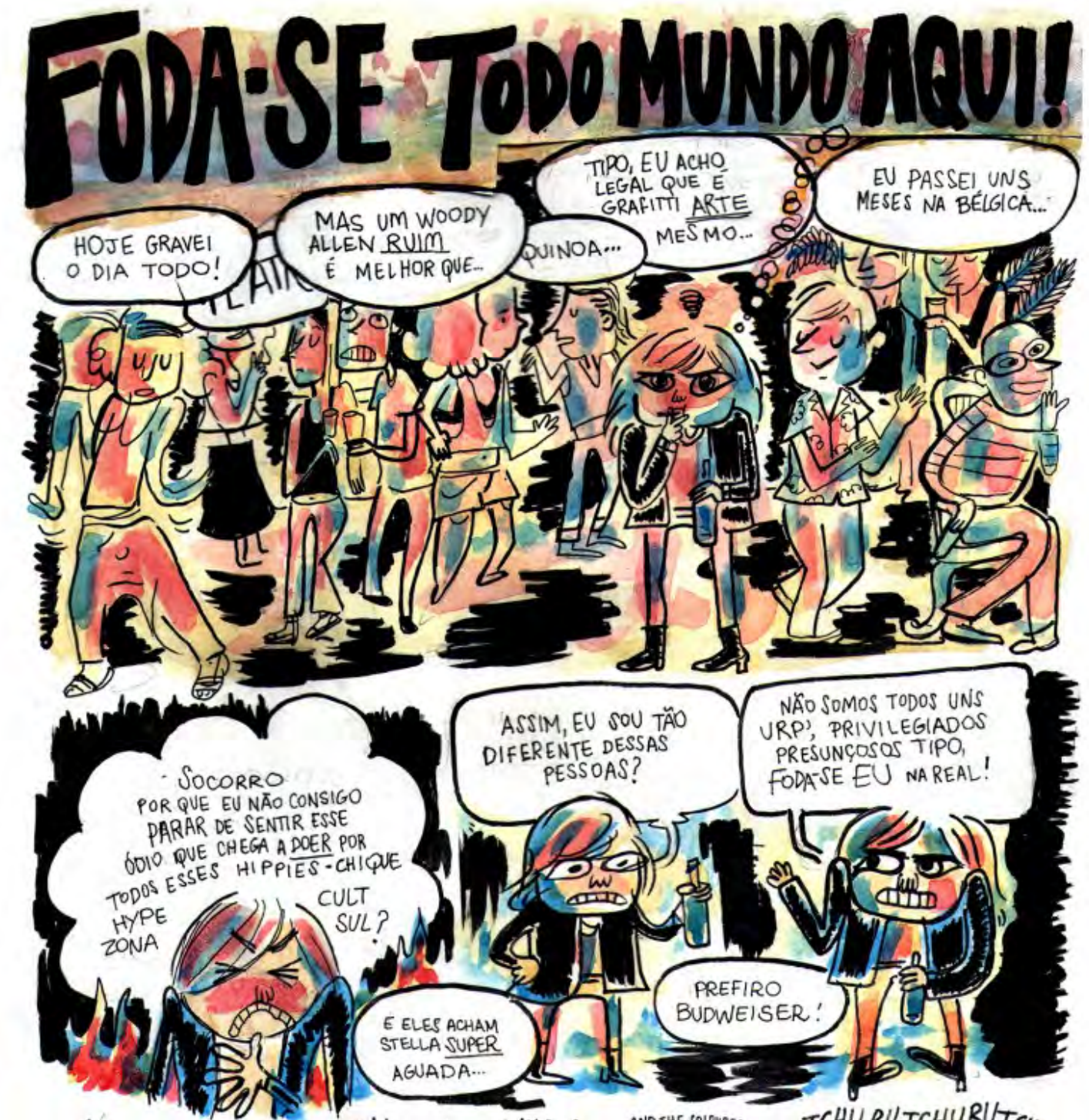

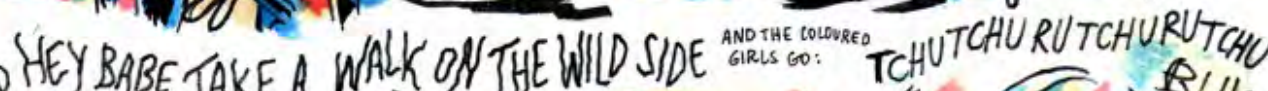

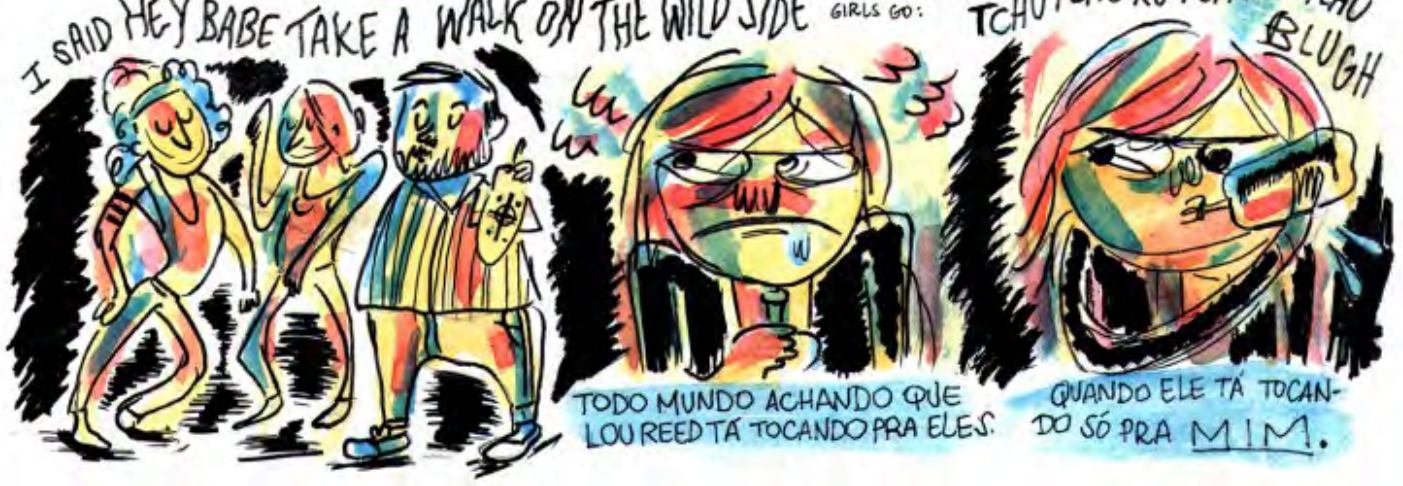

Figura 56 - Foda-se todo mundo aqui, de Cynthia B.

No que refere especificamente à matriz da autobiografia em quadrinhos brasileira, identificamos dois fenômenos. Primeiro, existe uma influência direta e contínua das produções norte-americanas sobre os artistas brasileiros, como Caeto, Cynthia B. e o casal Paulo Crumbim e Cristina Eiko. No álbum Memória de 
Elefante (2010), Caeto desenvolve um projeto de autobiografia longo e consistente, algo bastante raro no âmbito nacional, onde as narrativas curtas são mais comuns. $\mathrm{O}$ modelo é bastante semelhante à obra de Brown, mais baseado na exterioridade da ação, que aborda sua passagem para a vida adulta e seu relacionamento com seu pai portador do vírus da aids. Cynthia B., que publica principalmente em seu blog e em revistas alternativas (Golden Showen, Bananas), concentra-se num estilo fragmentado de autobiografia, mais concentrado nas suas percepções e experiências pessoais que na exterioridade da ação (Figura 56). Crumbim e Eiko, por sua vez, apresentam histórias bem mais humorísticas, mesmo quando se concentram em experiências reais. A série Quadrinhos A2 já consta com três volumes publicados, todas compilando histórias curtas, muitas publicadas previamente no blog mantido pela dupla. A despeito dessas tentativas pontuais de emular o estilo de autobiografia da matriz norte-americana, o mais comum é que os cartunistas brasileiros sigam o modelo de autocomicidade desenvolvido na série Angeli em Crise, utilizando, inclusive, a tira como formato preferencial para suas obras.
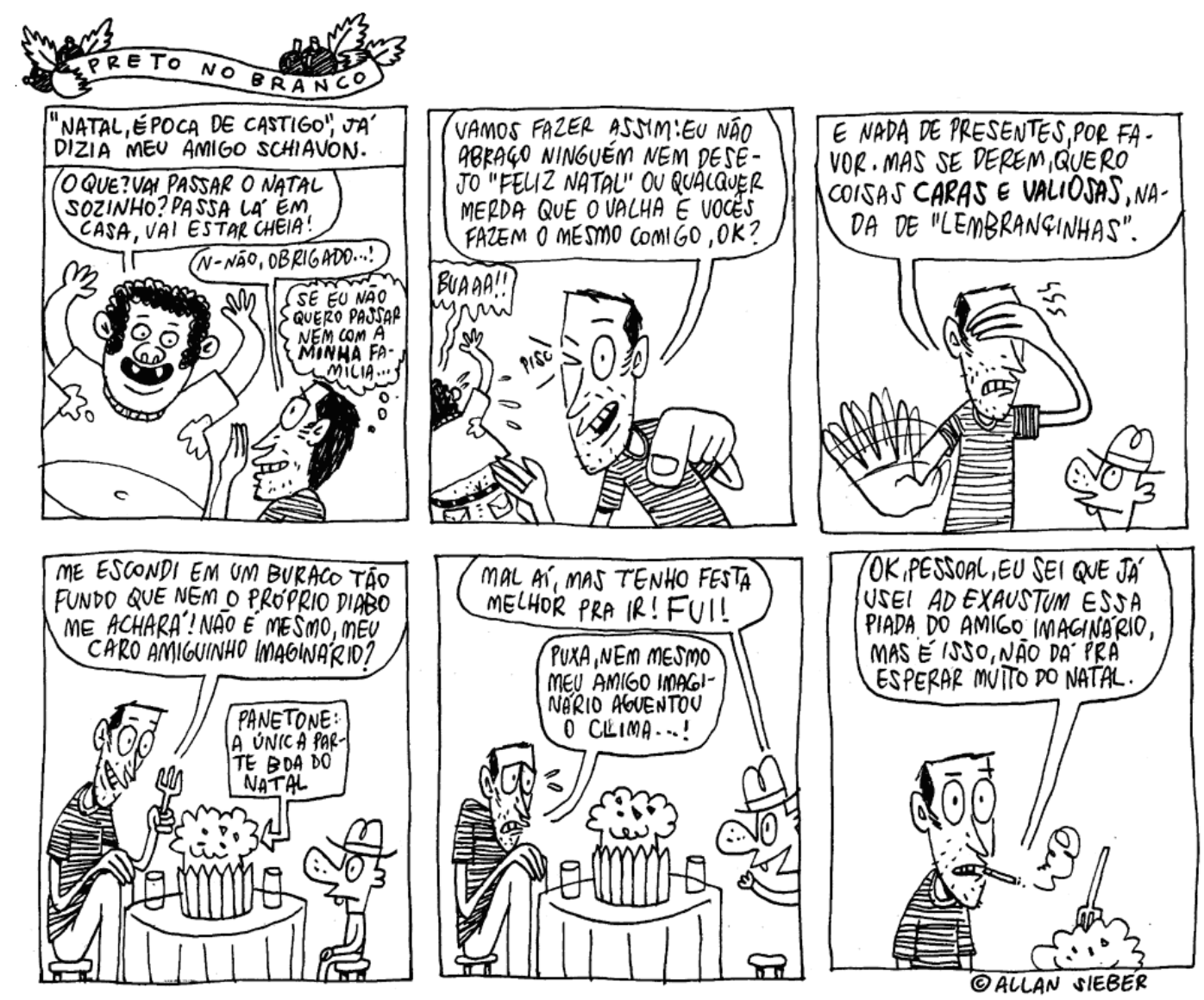

Figura 57 - Preto no Branco, de Allan Sieber 
A popularização da internet teve uma influência marcante sobre os quadrinhos desenvolvidos no Brasil a partir da primeira década do presente século. Essa modalidade de publicação independente permitiu que um grande número de novos autores apresentasse seu trabalho. Alguns, após conquistarem certa popularidade na $w e b$, acabam por migrar para os jornais. É interessante que muitos desses cartunistas surgidos na web utilizam-se de forma recorrente de histórias autocômicas, destacando-se o trabalho de Allan Sieber, André Dahmer, Ricardo Coimbra, Chiquinha (pseudônimo de Fabiane Bento Lagone), Caio Gomez, Daniel Lafayette. Além disso, veteranos como Adão Iturrusgarai e Laerte também frequentemente apresentam histórias que se enquadram nessa modalidade. Embora alguns desses quadrinhistas possuam um estilo muito particular e construam abordagens autocômicas mais reflexivas (Dahmer) e experimentais (Laerte), a influência da série Angeli em Crise ainda se faz presente. Em outros casos, como Sieber, Iturrusgarai e Chiquinha, o modelo encontrado é bastante semelhante ado desenvolvido por Angeli. A abordagem autodepreciativa, irônica e exagerada da obra de Sieber (Figura 57), por exemplo, emula o mesmo tipo de narrativa que identificamos no trabalho de Angeli. Assim, embora as obras autobiográficas norte-americanas sejam conhecidas pelo público, o estilo de tira cômica autobiográfica surgido nos anos 1980 ainda se mantém como influência principal para os cartunistas que se aventuram a utilizar a vida como matéria para a arte. 


\subsection{Autobiografia, biografia e jornalismo: derivação e resiliência}

Na década de 1980 Art Spiegelman inicia seu projeto biográfico Maus, publicado inicialmente em fascículos na revista de histórias em quadrinhos e artes gráficas de vanguarda Raw e depois em formato de livro. A narrativa desenvolvida nessa obra difere bastante das tradicionais biografias em quadrinhos. Conforme Santiago García (2012, p.94), a biografia surge nos quadrinhos ainda durante a década de 1930, com a publicação de dois livretos de litogravuras: Abraham Lincoln (1933) e Benjamin Franklin (1935), ambos de Charles Turzak. Embora não exista um consenso em classificar a obra de Turzak como quadrinhos, essas duas publicações já demonstram algumas das tendências que a biografia em quadrinhos seguiria nas décadas seguintes, como a concentração em torno de figuras ilustres e o tom heroico da narrativa. A maior parte das biografias em quadrinhos publicadas nos Estados Unidos vincula-se a projetos de construção de modalidades narrativas mais culturalmente aceitas, um projeto educacional que também engloba as adaptações de clássicos da literatura.

Nesse contexto, Maus apresenta importantes inovações temáticas, de conteúdo e de forma. No que se refere à temática, acontece um deslocamento na natureza da personagem biografada. Se a biografia nos quadrinhos sempre se ocupou das grandes personalidades e seus feitos extraordinários, Maus ocupa-se de um homem comum envolvido numa situação excepcional. O conteúdo dessa obra também difere bastante das biografias tradicionais, já que se ocupa em representar uma experiência de vida e não em construir um modelo de vida exemplar, ou uma representação heroica da personalidade do biografado.

No que se refere a questões formais, a modelo biográfico desenvolvido por Spiegelman mostra-se ainda mais iconoclasta. As biografias em quadrinhos normalmente seguem uma estrutura fixa, com uma narrativa em terceira pessoa que se inicia na infância e, episodicamente, dá conta de toda a existência do indivíduo até sua morte. Em Maus, temos um modelo de biografia completamente relacionado com as convenções da autobiografia. A autobiografia serve primeiramente como um estruturante da narrativa, onde acompanhamos a vida do autor Art Spiegelman, que visita o pai, faz as entrevistas, conversa com a esposa, vai ao psicanalista, etc. Em um segundo nível da narrativa, temos um dispositivo que transforma o depoimento do pai numa narrativa em quadrinhos em primeira pessoa que, em muitos sentidos, constitui- 
se também como uma autobiografia. Esse jogo formal entre categorias e posições narrativas relaciona-se com a fluidez que o gênero biográfico adquire na contemporaneidade. Conforme Lejeune

Quanto à palavra "biografia", ela designa hoje, dependendo de quem a emprega: 1) a história de um homem (em geral célebre) escrita por outrem (é o sentido antigo e mais comum); 2) a história de um homem (em geral obscuro) contada oralmente por ele próprio a outra pessoa que o levou a empreender essa narrativa para estudá-la (é o método biográfico das ciências sociais); 3) a história de um homem contada por ele próprio a outra ou outras pessoas que o ajudam, com sua escuta, a se orientar na vida (é a (auto)biografia feita no âmbito da formação) (LEJEUNE, 2008, p.53).

Nesse sentido, o trabalho de biógrafo executado por Spiegelman diz respeito à seleção e encadeamento de pequenos eventos narrativos que constroem um retrato vívido da personalidade do biografado; a tensão clássica entre os fatos e a esfera imaginativa do biógrafo. É interessante inclusive perceber a escolha narrativa que Art executa em Maus: em nenhum momento vemos cenas da infância e adolescência de seu pai, tudo se inicia nos momentos imediatamente anteriores ao casamento de Anja (a mãe de Art Spiegelman) e concentra-se basicamente em sua experiência durante o holocausto, como se essa parte de sua vida pudesse equivaler a todo o resto. $\mathrm{O}$ choque entre esse homem idealizado e o idoso avarento, controlador e neurótico é um dos pontos mais significativos e reveladores dessa narrativa. Em um primeiro nível, Maus configura-se como uma autobiografia; e, em um segundo nível, como um modelo de biografismo modal que se utiliza também das convenções e estrutura da aubiografia. Assim, apesar de seu caráter biográfico, Maus se estrutura em um âmbito formal e discursivo como autobiografia.

Quando comparada a outras autobiografias em quadrinhos, Maus chama atenção pela utilização de animais como metáfora para as relações de poder entre judeus, alemães e norte-americanos, recurso que elimina o vínculo entre a pictografia e a aparência das pessoas a que remetem. Mesmo assim, existem dispositivos que desenvolvem relações de referencialidade com a realidade visual, que podem ser mascarados pela apropriação que Spiegelman faz dos funny animals. Em primeiro lugar, as personagens de Maus (Figura 58) seguem a risca a anatomia do corpo 
humano, assemelhando-se a pessoas comuns com cabeças ou máscaras de animais, enquanto que os funny animals tradicionalmente reproduzem toda a aparência do animal (Donald tem pés de pato, Mickey tem rabo, etc). Essa decisão aproxima as personagens de seus equivalentes em carne e osso, por respeitarem formas naturais de percepção. Outro aspecto de referencialidade é a forma obsessiva com que Spiegelman procura reproduzir ambientes, paisagens e objetos, particularmente quando reconstitui alguma cena passada durante a Segunda Guerra Mundial, processo detalhado no livro Metamaus (SPIEGELMAN, 2011). Além de tentar reproduzir em termos visuais as descrições feitas pelo seu pai, Spiegelman em diversos momentos da narrativa faz referência à pesquisa paralela que vem desenvolvendo sobre o Holocausto. Assim, apesar da configuração simples, é possível perceber em Maus índices de reconhecimento que remetem a uma experiência real e historicamente delimitada.
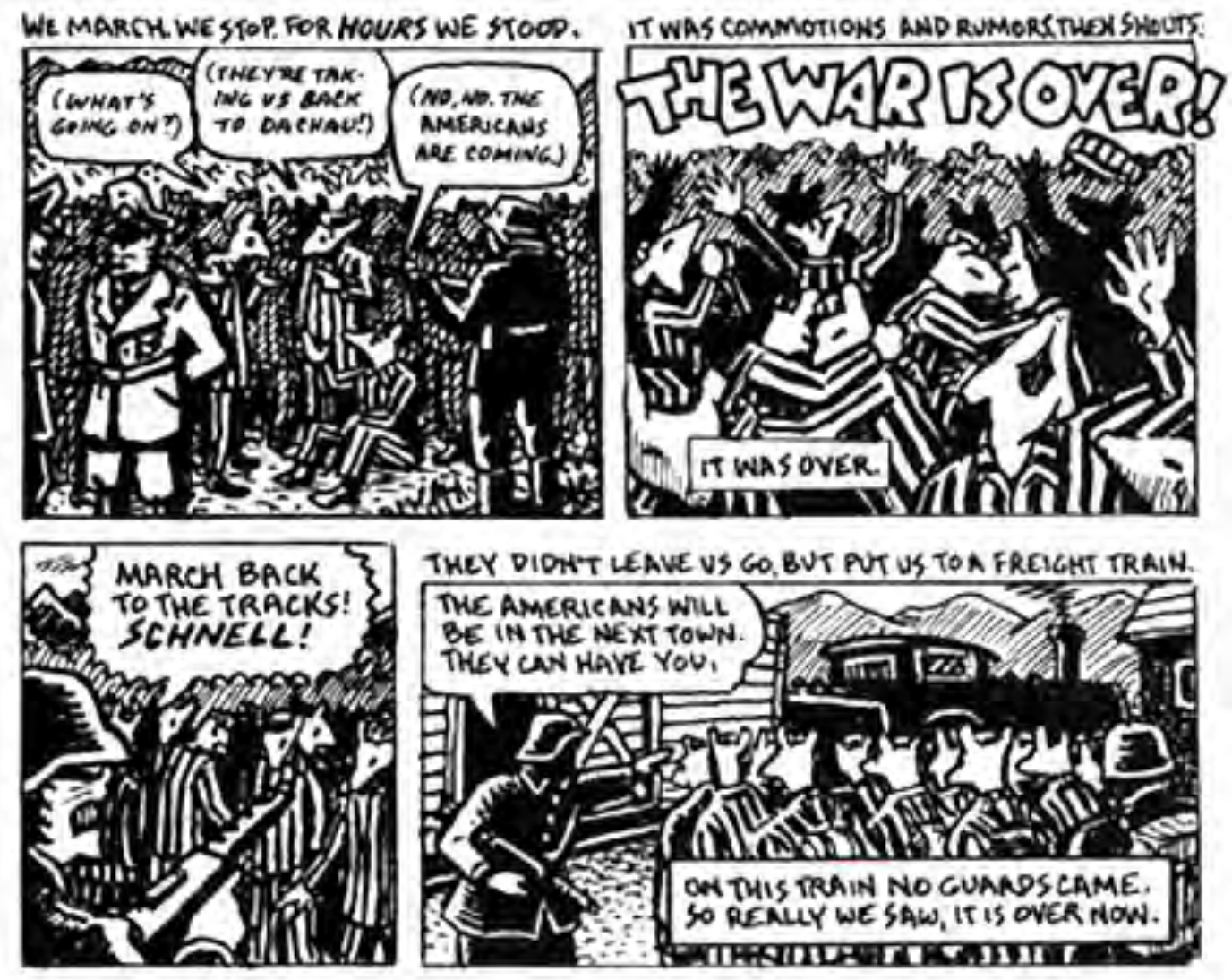

Figura 58 - Maus, de Art Spiegelman

Assim como estilo de biografia encontrado em Maus, a reportagem em quadrinhos desenvolvida por Joe Sacco também se assenta sobre a estrutura e as 
convenções narrativas da autobiografia. Quando consideramos o percurso do trabalho de Sacco, esse papel eminente da autobiografia como modalidade delimitadora de um modelo narrativo fica ainda mais evidente. $\mathrm{O}$ autor inicia-se na autobiografia com histórias curtas como Gênio dos quadrinhos, Carne, Na companhia do cabelo comprido, Uma experiência nojenta e Viagem o fundo da biblioteca, publicadas na revista Yahoo! entre 1988 e 1991 (SOUZA JÚNIOR, 2010). Essas narrativas seguem o modelo tradicional desenvolvido por Crumb, abordando experiências de vida sob a perspectiva neurótica de Sacco. Essas histórias em quadrinhos normalmente abordam eventos banais, como suas preferências alimentares ou experiências estressantes de trabalho, mas na história Como amei a Guerra (2006) (Figura 59) acontece um interessante deslocamento, onde o autor começa e enfatizar sua relação particular com o jornalismo.

Em Como amei a Guerra, vemos o autor/personagem Sacco assistindo obsessivamente à cobertura televisiva da Guerra do Golfo. Embora a história em quadrinhos também mostre outros aspectos do cotidiano, como uma conversa de bar com os amigos ou uma aula de alemão, o ponto central da trama é a relação que o autor desenvolve com a cobertura falaciosa que está sendo veiculada na TV. Como amei a Guerra é uma autobiografia que tem o jornalismo como tema. Se considerarmos que os autobiógrafos normalmente abordam temas que possuem uma importância marcante na formação de sua personalidade (Crumb aborda o sexo, Spiegelman sua vida familiar) é bastante sintomático que Sacco escreva sobre o jornalismo.

Esse projeto de aproximação entre a linguagem dos quadrinhos e o jornalismo é concretizado por Sacco em 1993, com a publicação da reportagem Palestina. Nessa obra, pela primeira vez acontece a apropriação de uma prática ligada ao núcleo duro do jornalismo pela linguagem dos quadrinhos, dando origem ao chamado jornalismo em quadrinhos. Segundo o próprio autor, o mote dessa reportagem seria "dar voz a árabes anônimos", já que a cobertura jornalística tradicional tomava claramente o lado dos Israelenses no que se refere à ocupação dos territórios palestinos. Para dar cabo desse intento, Sacco se engaja numa viagem de dois meses pela Cisjordânia, Israel e Faixa de Gaza, colhendo depoimentos e registrando condições de vida nos territórios ocupados. Nesse sentido, Sacco constrói uma reportagem muito tradicional, baseado em pesquisa de campo, entrevistas e utilização de dispositivos técnicos de registro de som e imagem. A forma, contudo, possui uma configuração 
menos ortodoxa, já que incorpora a estrutura e as convenções narrativas da autobiografia.

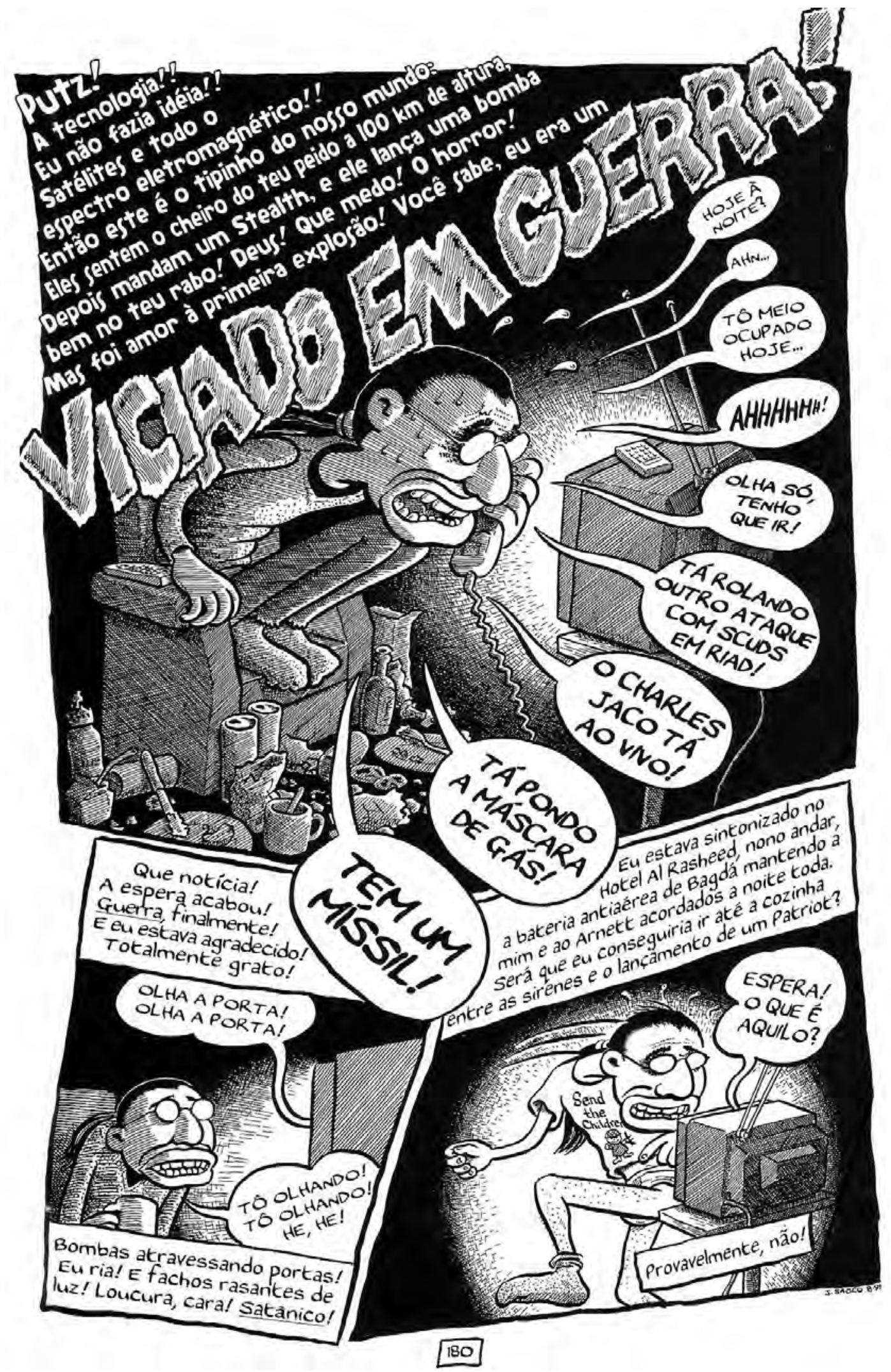

Figura 59 - Como amei a Guerra, de Joe Sacco 
O caráter autobiográfico das reportagens de Sacco normalmente é explicado considerando uma suposta influência de movimentos do jornalismo literário, como o new journalism e o gonzo journalism (DUTRA, 2003, p.56; MACIEL 2007, p. 26). Embora certamente Sacco conheça o trabalho de autores com Tom Wolfe e Hunter Thompson, essa hipótese apresenta muitas falhas. Se nos concentrarmos apenas na questão do jornalismo literário, podemos perceber o quanto essa aproximação com a reportagem em quadrinhos ou com o jornalismo em quadrinhos como um todo é inadequada. O jornalismo literário consiste basicamente na utilização de expedientes e recursos próprios da literatura na construção do texto jornalístico. Essa aproximação entre o jornalismo e a literatura acontece de maneira bastante natural, seja pela proximidade entre as duas formas de manifestação ou pela notória quantidade de profissionais que exercem as duas profissões. Segundo Edvaldo Pereira Lima

Entre o jornalismo e literatura existia em comum, nesses tempos pioneiros da era moderna [última metade do século XIX], o ato da escrita. À medida que o texto jornalístico evolui da notícia para a reportagem, surge a necessidade de aperfeiçoamento das técnicas de tratamento da mensagem. Por uma condição de proximidade, estabelecida pelo elo comum da escrita, é natural compreender que, mesmo intuitivamente ou sem maior rigor metodológico, os jornalistas sentiam-se então inclinados a se inspirar na arte literária para encontrar os seus próprios caminhos de narrar o real (LIMA, 1993, p.135).

Além da influência da literatura na constituição inicial de um modelo de reportagem, ainda podemos perceber uma tradição bastante consolidada de livros que aproximam um modelo de grande reportagem com recursos e um estilo advindos da literatura. Lima (1999) e Felipe Pena (2009) traçam um percurso das obras mais influentes desses jornalistas-escritores que se inicia com Daniel Defoe, considerado o primeiro jornalista literário moderno (PENA, 2009, p.53), passa por George Orwell (Na pior em Paris e Londres, Dias da Birmânia), Jonh Reed (10 dias que abalaram o mundo), Jonh Hersey (Hiroshima), Truman Capote (A Sangue Frio), os membros vinculados ao new journalism (como Tom Wolfe, Norman Mailer e Gay Talese), o gonzo journalism de Hunter Thopson e os brasileiros Euclides da Cunha (Os sertões) e João do Rio (A alma encantadora das ruas). 
Considerando a natureza autônoma dos quadrinhos como mídia, isto é, sua independência como modalidade expressiva que não pode ser subsumida a categorias literárias (ou subliterárias, como é mais comum), defendida por diversos teóricos como Scott McCloud (2005), Waldomiro Vergueiro (2004), Moacy Cirne (2000) e Paul Gravett (2005), podemos inferir que o trabalho de Sacco não poderia se inserir nessa tradição de jornalistas literários. A única semelhança entre o jornalismo literário e o jornalismo em quadrinhos é que os dois se originam de aproximações entre o jornalismo e outras linguagens. Contudo, essa relação de aproximação é completamente diferente em cada caso. Se considerarmos o jornalismo como um eixo horizontal, a literatura e os quadrinhos seriam representados como dois eixos verticais independentes que em algum ponto estabelecem uma relação de transversalidade com o eixo do jornalismo. Assim, o jornalismo literário surge da aproximação jornalismoliteratura e o jornalismo em quadrinhos, por sua vez, da relação jornalismoquadrinhos. A única semelhança entre as duas é a aproximação entre o jornalismo e outras formas de expressão.

As supostas influências do new journalism e do gonzo journalism sobre a reportagem em quadrinhos são ainda mais difíceis de estabelecer. O movimento de new journalism surge nos Estados Unidos, durante a década de 1960, em decorrência da insatisfação de alguns jornalistas com as rotinas produtivas das redações que impediam o desenvolvimento de reportagens em profundidade. Os principais expoentes desse movimento, Tom Wolfe, Gay Talese e Norman Mailer, tentavam revigorar o modelo de grande reportagem investigativa, agregando elementos da narrativa literária com uma maior ênfase no estilo e na experimentação. Segundo Jorge Pedro Sousa

O movimento do Novo Jornalismo surge como uma tentativa de retomada do jornalismo aprofundado e de investigação por parte dos jornalistas e escritores que desconfiavam das fontes informativas tradicionais e se sentiam descontentes com as rotinas do jornalismo, mormente com suas limitações estilísticas e formais (SOUSA, 2002, p.203).

Percebe-se ainda no new journalism uma ampliação do conceito de pauta, a construção aprofundada de perfis humanos, a incorporação de temas que 
tradicionalmente não são abordados pela imprensa, tendência à esquerda política e uma ênfase no papel do autor. Desse modo, sua vinculação à reportagem em quadrinhos geralmente é estabelecida pelo caráter de originalidade das duas manifestações. O new journalism, e principalmente seu membro fundador Tom Wolfe, cuidadosamente cultivam a imagem de um movimento revolucionário, que trouxe frescor e inventividade ao jornalismo tradicional. No entanto, suas características principais são as mesmas do jornalismo literário, com inovações ligadas principalmente à temática esquerdista, que durante os anos 1960 despertava o interesse de determinados setores da elite estadunidense, como aquelas referentes aos Panteras Negras, à psicodelia e ao movimento pelos direitos civis. Na verdade, as inovações estilísticas e formais do new journalism são bastante discretas e pontuais, como esclarece Lima

Enquanto Wolfe também renovou trazendo para o jornalismo o recurso do fluxo de consciência - a reprodução do pensamento do personagem, geralmente na forma desorganizada como várias coisas simultâneas nos vêm à mente -, até então privilégio da literatura, Norman Mailer criou o chamado ponto de vista autobiográfico. Trata-se do artifício em que o repórter faz referência a ele próprio, no texto narrativo, como se fosse um outro alguém qualquer (LIMA, 1998, p.50).

Considerando o fluxo de consciência e ponto de vista autobiográfico como as genuínas inovações do new journalism, impõe-se um distanciamento da reportagem em quadrinhos, já que no trabalho de Sacco não são encontrados indícios desses dois recursos. Não conseguimos encontrar em nenhuma obra de Sacco trechos em que ele tente reproduzir o pensamento de alguma personagem e a sua narrativa dá-se em primeira pessoa.

O suposto diálogo entre a reportagem em quadrinhos e o gonzo journalism é ainda mais obtuso. O gonzo journalism agrega tendências do new journalism e é fortemente associado à figura de seu criador, Hunter S. Thompson, que conseguiu construir em torno de si uma forte imagem de ícone da contracultura. Embora Thompson tenha sido alçado ao sucesso com sua reportagem quase que antropológica sobre uma gangue de motociclistas, o estilo que tem sido considerado como "gonzo" surge apenas em 1970 com a publicação de "The Kentucky Derby is Decadent and 
Depraved", na revista de esportes Scanlan's Montly. No ano seguinte, é publicado Medo e delírio em Las Vegas, obra que melhor condensa as características do gonzo: exploração de estados alterados de consciência; ficcionalização da realidade; tendência extremada à divagação e fuga do tema principal; referências à cultura pop e personalidades; exploração de temas como violência, consumo de drogas, sexo, política e esportes; narração em primeira pessoa; humor sarcástico e vulgar; e ênfase em um estilo próprio e no uso criativo da língua. Essas características particulares do gonzo não são encontradas no trabalho de Sacco, que desenvolve uma reportagem bastante tradicional no que se refere ao seu método de trabalho e à linguagem utilizada. Ao que podemos perceber, a vinculação da reportagem em quadrinhos ao new journalism ou ao gonzo acontece não por questões inerentes ao produto, e sim pela natureza de experimentação que a transposição de um gênero tradicional do jornalismo (grande reportagem) para a mídia quadrinhos supostamente comporta. Uma leitura atenta de qualquer trabalho jornalístico de Sacco desestimula qualquer aproximação com o jornalismo literário ou qualquer rótulo associado. O que encontramos é, justamente, uma forte influência das convenções da autobiografia, tematizadas em sua obra antes mesmo do início do projeto de reportagens em quadrinhos.

A presença da autobiografia na reportagem em quadrinhos atesta uma grande resiliência dessa modalidade de narrativa do eu na produção dos quadrinhistas underground. Existe, contudo, uma diferença significativa entre os modelos de autobiografias desenvolvidos nos Estado Unidos, onde é possível identificar pelo menos duas grandes correntes: centrípeta, onde a narrativa constantemente remete para a interioridade do indivíduo; e centrífuga, em que a história individual funciona como uma porta de acesso a uma realidade social mais ampla. O modelo centrípeto foca quase que exclusivamente nas experiências e percepção subjetiva do indivíduo, como nas narrativas de Robert Crumb, Harvey Pekar, Chester Brown e Alison Bechdel, que abordamos anteriormente. Já o modelo centrífugo, aproxima-se de Maus, cuja estrutura funciona como uma série de camadas que se expandem do indivíduo para a realidade social e histórica. Numa primeira camada temos um modelo de autobiografia introspectiva, onde o autor se detém em suas experiências pessoais como um judeu filho de sobreviventes de Auschwitz. Nesse ponto entram em cena suas inadequações sociais, sua relação tumultuada com seu pai e o suicídio de sua mãe. Em uma segunda e mais externa camada, o autor se concentra nas 
memórias de seu pai. O movimento centrífugo dessa narrativa expande essas camadas que se distanciam do frame individual para abarcar o espectro que cobre a geração de judeus subsequente a Auschwitz. Maus constitui-se, portanto, como uma autobiografia que parte do indivíduo para representar fenômenos sociais complexos, enquanto que o modelo de autobiografia centrípeta parte do indivíduo para explorar as camadas internas de sua psique.

$\mathrm{Na}$ obra de Sacco identificamos a transformação de um modelo de autobiografia centrípeta para um estilo de autobiografia centrífuga, já que quando o autor inicia o projeto da reportagem em quadrinhos em Palestina, acontece uma mudança significativa no estilo de autobiografia, que abandona o tom confessional e a exposição da intimidade para se concentrar em experiências que dizem respeito à atividade do repórter (SOUZA JÚNIOR, 2010). O caráter centrífugo dessa autobiografia afasta constantemente a narrativa das idiossincrasias do autor para se concentrar na exterioridade que forma propriamente o corpus da reportagem. Dessa forma, a presença da autobiografia no modelo de reportagem quadrinizada desenvolvido por Sacco desempenha funções importantes dentro da atividade jornalística proposta: atesta a presença do autor no ambiente e o contato direto com as fontes e entrevistados; demonstra o método de apuração da reportagem; e funciona como uma porta de entrada para uma realidade exótica. A autobiografia presente em Palestina constrói, portanto, um pacto de leitura que determina uma equivalência entre os fatos narrados e a exterioridade dos acontecimentos. Além de uma função estruturante na narrativa, a autobiografia acaba por desempenhar funções que reforçam e ressignificam a prática da reportagem. Assim, a presença de Sacco na reportagem em quadrinhos contorna um possível efeito de opacidade para servir como fio condutor na experiência jornalística. O que é experiência em outros tipos de autobiografia transforma-se em informação em Palestina.

No que se refere ao mercado de quadrinhos do Brasil, não identificamos modelos de biografismo que se assemelhem ao desenvolvido por Spiegelman. A reportagem em quadrinhos de Sacco, por outro lado, tem influenciado diversos autores. A partir do ano de 2007, é possível encontrar exemplos na grande imprensa: nesse ano o jornal $\boldsymbol{A}$ Tarde publicou um encarte especial de 30 páginas sobre o movimento estudantil; em 2009, o Correio Brasiliense publicou uma reportagem sobre usuários de crack; e, em 2010, o jornal Extra publicou uma história em quadrinhos especial com 16 páginas coloridas sobre a pacificação do Morro do 
Alemão, favela do Rio de Janeiro. Essa edição do jornal Extra, inclusive, inovou ao trazer uma capa totalmente em quadrinhos (Figura 60).

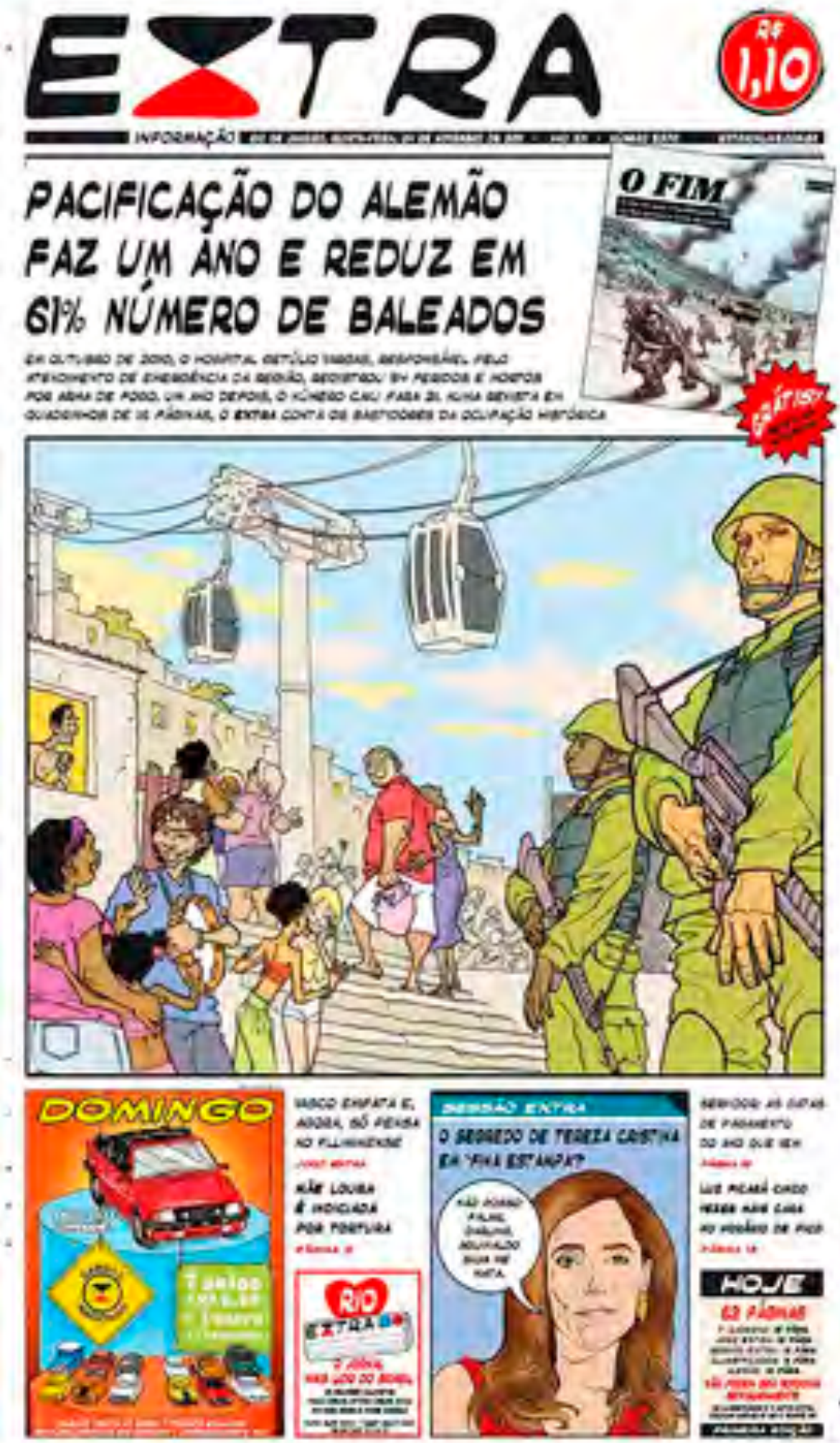

Figura 60 - Jornal Extra 
No circuito de publicação independente, também podem ser encontrados alguns autores que esporadicamente dedicam-se ao jornalismo em quadrinhos. Em 2010, o jornalista Beto Leite em parceria com o ilustrador Marcos Guerra produziram o quadrinho de 10 páginas $\mathbf{O}$ que vai ser derrubado com o Machadão, sobre a reforma do estádio de futebol da cidade de Natal para a Copa de 2016. No mesmo ano, a revista Continuum publicou reportagem sobre o clube de futebol Juventude, escrito por Augusto Paim e Ana Luiza Goulart. Em 2011, Paim em parceria com o ilustrador Maumau, produziram a reportagem Inside the Favelas, publicada no site Cartoon Movement. Além disso, o cartunista Daniel Gnattali frequentemente faz coberturas de eventos em quadrinhos, inclusive cobriu a participação de Joe Sacco na Flip, em 2011.

Contudo, no Brasil o autor mais frequentemente associado ao jornalismo em quadrinhos é Allan Sieber. Entre 2005 e 2007, Sieber produziu uma série de colunas e reportagens em quadrinhos, publicadas nas revistas Trip e Playboy. Esses quadrinhos, juntamente como outras obras autobiográficas e não-ficcionais do autor, foram posteriormente reunidas no livro É Tudo Mais ou Menos Verdade - O Jornalismo Investigativo, Tendencioso e Ficcional de Alan Sieber, publicado em 2009. O livro ganhou o prêmio HQ Mix de Melhor Publicação de Humor em 2010 e, até o momento, se mantém como a única obra nacional de jornalismo em quadrinhos publicada por uma editora comercial. 


\section{CONSIDERAÇÕES FINAIS}

A autobiografia em quadrinhos é uma modalidade de escrita de si que dialoga diretamente com sua contraparte literária, tanto que as proposições teóricas advindas desse campo mostraram-se bastante úteis para a análise da obra de Robert Crumb, Angeli e outros autores. Contudo, o aspecto visual encontrado nessas narrativas constitui-se como uma contribuição original da linguagem dos quadrinhos para o universo da autobiografia. Esse é um dado muito significativo, já que a relação entre memória e imagem sempre foi destacada pela filosofia ocidental, fenômeno que remete ainda à herança grega (RICOEUR, 2008, p.27). O polo imaginativo da prática da autobiografia também se relaciona diretamente com a cultura da imagem, já que durante o ato da leitura o receptor é levado a construir um certo tipo de imagem mental que corresponde, em maior ou menor grau, ao desenrolar das memórias (CALVINO, 1999, p.99). Na autobiografia em quadrinhos, por outro lado, as imagens existem como dados concretos e materiais. Não é preciso imaginar: as imagens dão conta de reproduzir, em maior ou menor grau, as memórias do autobiógrafo. Disso decorrem fenômenos interessantes, já que o leitor tem acesso às imagens da memória do artista de forma mais direta, sem depender de sua própria imaginação para construir essas imagens. Esse aspecto visual da autobiografia em quadrinhos também possui um maior potencial informativo decorrente da informação pictográfica. Justamente por isso, o modelo autobiográfico mostrou-se adequado como estruturante para as experiências da reportagem em quadrinhos de Joe Sacco. Finalmente, toda a informação gráfica construída pelos artistas carrega indícios importantes no que se refere à própria prática da autobiografia. $\mathrm{O}$ grafismo e a imagem encontrada nessas obras correspondem a um certo tipo de construção mais ampla da memória. Nesse sentido, o próprio estilo particular de cada artista é uma forma de escrita de si, ou "pictografia de si", para sermos mais precisos.

No outro espectro da relação "autobiografia - quadrinhos" temos as contribuições dessa modalidade de escrita de si para o desenvolvimento da mídia. Os aspectos formais desse processo já foram suficientemente abordados no decorrer deste estudo: ampliação temática; a noção da experiência vivida; aproximação com o cotidiano, os dramas humanos e a psicologia individual; e a construção de uma estrutura narrativa adequada para abordar a realidade social e histórica. Resta-nos um 
último ponto, que diz respeito à contribuição da autobiografia para a valorização dos quadrinhos como objeto artístico. Esse movimento contínuo e ainda não devidamente concretizado de aproximação entre os quadrinhos e a "instituição arte" (BÜRGER, 2012, p.38) acontece de forma complexa em várias frentes. Contudo, a autobiografia em quadrinhos ocupa um lugar central nesse processo, construindo um tipo de objeto material que pode ser mais facilmente aceito dentro dessa instituição arte, já bastante abalada pelos movimentos modernos de contestação (BÜRGER, 2012, p.56-57).

O processo de aproximação dos quadrinhos com o universo da arte remete diretamente ao período imediatamente posterior ao ocaso dos comix. Esse movimento artístico contribuiu imensamente para a expansão das possibilidades formais dos quadrinhos mas, no que se refere à sua aceitação social, os efeitos foram bastante negativos, dado seu apego a temáticas com sexo, drogas e subversão em geral. Nesse contexto, a autobiografia se destaca como uma modalidade de expressão mais socialmente aceitável e como tipo de publicação comercialmente viável para um público saturado dos excessos dos comix. Outra consequência do fim do movimento comix foi a desarticulação do modelo de distribuição baseado em headshops. Os quadrinhos mais underground migraram para as comic shops, lojas especializadas em quadrinhos e produtos nerd, que utilizavam um sistema de compra prévia, o chamado "mercado direto".

Assim, o material autoral inspirado nas inovações dos comix assume uma nova designação, sendo comumente chamado de quadrinhos alternativos ou independentes. Embora ambas as categorias sejam semelhantes, publicando quadrinhos que não se encaixam no modelo mercadológico vigente, existem diferenças significativas. Os quadrinhos alternativos se assemelham a um tipo de produção mais ligada ao underground, enquanto que os quadrinhos independentes utilizam-se das fórmulas do mercado mainstream (HATFIELD, 2005, p.26). As histórias em quadrinhos autobiográficas ocupam um lugar central no desenvolvimento desse mercado de quadrinhos alternativos (HATFIELD, 2005, p.x). Nesse contexto, são desenvolvidos os primeiros experimentos autobiográficos que tratam de assuntos socialmente relevantes. Maus é talvez o melhor exemplo desse fenômeno. A própria revista Raw, onde o trabalho de Spiegelman foi originalmente publicado, tinha claramente a intenção de ser um produto "artístico", de vanguarda (GÁRCIA, 2012, p.197). 
Nesse período, os quadrinhos autobiográficos já se adequavam, em termos de forma e conteúdo, a um estilo de narrativa socialmente relevante que os aproxima do universo da arte. Contudo, a questão do formato ainda impedia que o público não familiarizado com o universo dos quadrinhos tivesse acesso a essas produções. Até a década de 1980, os quadrinhos dos Estados Unidos eram publicados prioritariamente no formato comic book. A partir da década de 1980 esses tipo de publicação periódica migra das bancas de jornais comuns para as comic shops, atingindo apenas os fãs de quadrinhos, que frequentavam essas lojas e acompanham suas séries de interesse. As primeiras publicações da série American Splendor, por exemplo, eram comercializadas exclusivamente nesse sistema. O formato conhecido como graphic novel (novela gráfica) instituiu um tipo de publicação, auto contido na unidade do livro e comercializado em livrarias comuns. Conforme García, a origem do termo graphic novel remete a alguns fanzines norte-americanos dos anos 1960, que faziam alusão a um conceito hipotético, "quadrinhos de maiores ambições artísticas do que os produtos padronizados que as grandes editoras levavam às bancas" (GARCÍA, 2012, p.32). Entretanto, o grande responsável pela popularização do conceito da graphic novel foi o quadrinhista Will Eisner, que começou a utilizar o termo para designar seu livro Um Contrato com Deus, publicado em 1978 (HATFIELD, 2005, p.29).

Os problemas referentes ao conceito de graphic novel são muitos. Embora, teoricamente, o termo designe um tipo de narrativa longa e autocontida, a indústria dos quadrinhos tem usado esse rótulo para designar indistintamente uma vasta gama de produtos, como coletâneas de histórias curtas, republicação de arcos previamente publicados no formato comic book. O próprio Um Contrato com Deus, de Eisner, é na verdade composto por quatro histórias curtas e não relacionadas. A questão "literária" tematizada pela graphic novel também se mostrou bastante problemática, por negar a autonomia da mídia quadrinhos e facilitar "que fossem julgados utilizando-se os critérios próprios da literatura, em vez de seus critérios específicos (GARCÍA, 2005, p.25). Contudo, reivindicar um status literário para os quadrinhos, processo que aconteceu também no âmbito da pesquisa teórica, demonstra uma tentativa de aproximar os quadrinhos de uma forma de arte consolidada. Segundo Ramos, "chamar quadrinhos de literatura, a nosso ver, nada mais é do que uma forma de procurar rótulos socialmente aceitos ou academicamente prestigiados [...] como 
argumento para justificar os quadrinhos, historicamente vistos de maneira pejorativa, inclusive no meio universitário (2009, p.17).

De qualquer forma, é certo que o formato da graphic novel foi em grande medida responsável pela migração dos quadrinhos para as livrarias, ambiente onde as histórias em quadrinhos tornam-se acessíveis ao leitor comum. É nesse contexto que a autobiografia se destaca como uma porta de entrada para o universo dos quadrinhos. Os quadrinhos, tradicionalmente, são um objeto de culto destinado a um nicho específico aficionados. Não raramente faz-se necessário um considerável conhecimento prévio para a fruição de suas narrativas. Os comics de super-heróis, por exemplo, acumulam décadas de uma rocambolesca cronologia. É certo que os quadrinhos destinados a jovens leitores (como no caso das revistas da Disney, Mauricio de Sousa, a produção franco-belga, etc) são muito acessíveis ao público e também gozam de grande popularidade mas sua própria natureza dificulta sua aceitação enquanto objeto artístico sério por parte da cultura estabelecida, pelo menos no contexto norte-americano. A autobiografia, por outro lado, é imediatamente acessível ao leitor não-iniciado, já que a experiência de vida é uma categoria comum e compartilhada a que qualquer pessoa pode se relacionar. Hatfield (2005, p.29-30) destaca que três obras foram responsáveis pela popularização do conceito de graphic novel na segunda metade da década de 1980: o primeiro volume de Maus (1986); Batman - O cavaleiro das Trevas (1986), de Frank Miller; e Watchmen (1987), de Alan Moore e Dave Gibbons). As duas últimas alcançaram grande notoriedade justamente pela renovação que efetuaram nos quadrinhos de super-heróis, tornandose um objeto muito mais interessante para o fã de quadrinhos que para o leitor comum. Maus, por outro lado, apresenta um tipo de narrativa que pode ser imediatamente fruído por qualquer interessado, o que destaca seu papel de divulgação dos quadrinhos "sérios".

Além disso, as histórias autobiográficas se aproximam bastante de um estilo de narrativa introspectiva e memorialista encontrada no âmbito do romance desde, pelo menos, a publicação de Em Busca do Tempo Perdido (1913 - 1022), de Marcel Proust e Retrato do Artista quando jovem (1916), de James Joyce (MELLO, 2013, p.12). Assim, a natureza dos quadrinhos autobiográficos os aproxima de formas literárias mais reconhecidas culturalmente, ao mesmo tempo em que os distancia dos lugares-comuns associados aos quadrinhos, como a "fantasia, a aventura e o horror" (WITEK, 1989, p.4). Para o criador que almeja mais 
respeitabilidade e aceitação social, a autobiografia (e outras modalidades relacionadas, como a biografia e o jornalismo) apresenta-se como uma alternativa bastante viável.

Durante a década de 1980, inicia-se também um processo de sedimentação da autobiografia em quadrinhos. Suas convenções tornam-se cada vez mais reconhecidas e reproduzíveis, processo que resulta da derivação que identificamos na obra de Spiegelman e Sacco e na influência que sua estrutura narrativa exerce sobre produções não necessariamente autobiográficas. Boa parte das mais aclamadas graphic novels contemporâneas seguem à risca a estrutura da autobiografia, tanto que poderiam facilmente ser percebidas como memórias. García (2012, p.253 e p.256) destaca duas obras recentes que, na sua leitura, são em grande medida responsável pela consolidação do processo de aceitação dos quadrinhos como objeto de expressão séria: Jimmy Corrigan (2000), de Chris Ware; Retalhos (2003), de Craig Thompson. Embora ficcionais, ambas as histórias poderiam ser consideradas como autobiográficas, caso se institui-se um pacto de leitura. Em Retalhos, uma narrativa que acompanha a primeira relação romântica de um rapaz religioso, a personagem principal inclusive chama-se Craig. O autor, contudo, sempre negou o caráter memorialístico da história. No Brasil, embora a autobiografia em quadrinhos tenha se desenvolvido de forma bastante diversa, também é possível perceber sua influência sobre a obra ficcional de artistas como Lourenço Mutarelli, Fábio Moon e Gabriel Bá. A autobiografia mostrou um caminho para a expressão intima e pessoal nos quadrinhos e a maior parte dos autores, talvez involuntariamente, não consegue fugir da sua sombra.

As convenções da autobiografia tornaram-se gradualmente tão estabelecidas que alguns autores até mesmo "brincam" com esse lugar-comum. Na história "Just Another Day" (publicada em 1993 na revista Eightball n5), Daniel Clowes faz uma crítica ácida a essa cultura de autoexposição, ironizando a estilo de narrativa mais naturalista e a impossibilidade do autor se representar adequadamente na linguagem dos quadrinhos. O quadrinhista Seth dá continuidade a esse tipo de experimento formal em It's a Good Life, If You Don't Weaken (1993 - 1996), conforme descreve García: 
Seth criou uma das primeiras grandes novelas gráficas (serializada em formato comic book, é claro) sobre a impostura da realidade, aproveitando a febre pela autobiografia: It's a Good Life, If You Don't Weaken mostrava a busca, por parte do autor, de Kalo, um velho e desconhecido cartunista do The New Yorker. Só depois que a obra estava terminada o público soube que Kalo havia sido uma invenção de Seth. O artifício havia funcionado porque o público havia se acostumado à desavergonhada sinceridade dos desenhistas autobiográficos, cuja principal premissa era a autenticidade (GARCÍA, 2012, p.218).

Esse tipo de narrativa irônica demonstra, por um lado, que as histórias em quadrinhos autobiográficas são uma categoria consolidada dentro do mercado. Elas também denotam o quanto a autobiografia tornou-se uma fórmula convencionada em estruturas muitas vezes tão rígidas quanto as encontradas nos quadrinhos mainstream. Não deixa de ser curioso que uma manifestação que, contribuiu para introduzir no universo dos quadrinhos a perspectiva da expressão íntima e individual tenha tomado contornos tão fortemente engajado com modelos mercadológicos. Certamente essa é lógica da indústria cultural, produzir cópias dos produtos mais rentáveis, mas supostamente não deveria acontecer num tipo de manifestação que almeja um status artístico e que se fundamenta, justamente, na expressão individual. Os pioneiros dos quadrinhos autobiográficos, como Robert Crumb, Justin Green e Art Spiegelman, eram visionários que tentavam ampliar as possibilidades formais da mídia, buscando novas formas de expressão. Uma vez que esse modelo adquire um status cultural mais elevado, é cooptado por diversos criadores, que se utilizam de seu capital simbólico. Esse fenômeno frequentemente resulta numa série de autobiografias em quadrinhos inconsistentes e enfadonhas que entulham as livrarias todos os anos.

Nesse sentido, a autobiografia tornou-se uma amarra para muitos artistas, um espectro que ronda boa parte dos criadores sem que eles, muitas vezes, se deem conta disso. A maior aceitação cultural da autobiografia em quadrinhos mostrou-se bastante benéfica para a mídia mas, ao mesmo tempo, parece ter reduzido as possibilidades criativas para os artistas que buscam um modelo de expressão individual. Uma aventura de ficção científica em um planeta distante pode ter os mesmo contornos existenciais e a mesma profundidade psicológica que identificamos em algumas autobiografias em quadrinhos mas, aparentemente, apenas as histórias que reproduzam categorias da realidade social e histórica podem almejar uma aceitação 
mais ampla dentro da “instituição arte”. É provável que décadas de hostilidade cultural aos quadrinhos tenham empurrado muitos criadores com pretensões "artísticas" na direção oposta aos temas tradicionais dos quadrinhos (horror, ficção científica, humor, aventura, etc). A autobiografia se mostrou muito adequada para esse artistas que fazem quadrinhos como quem pede desculpa. Isso leva a outra questão importante, já que, na nossa leitura, uma das características mais interessantes dos quadrinhos é a sua capacidade de construir representações que se distanciam completamente da realidade. Essa plasticidade da mídia, que permite que universos particulares e fantasias extravagantes assumam uma aparência material, é precisamente o que torna tão instigante o universo dos quadrinhos. Frente a esse potencial criativo das histórias em quadrinhos, a obsessão de alguns autores em reproduzir nos mínimos detalhes as experiências de vida mais irrelevantes mostra-se bastante desinteressante. Em muitos casos, parece que os criadores estão convencidos de que o mote da confissão intimista pode substituir o talento.

Frente a esse estado de estagnação da autobiografia em quadrinhos norteamericana, o estilo de autocomicidade que identificamos na obra de Angeli e outros quadrinhistas brasileiros, mostra-se mais original e consistente. A vinculação desse modelo de autocomicidade à tradição gráfica do humor brasileiro acaba afasta essa manifestação do lugares comuns da autobiografia em quadrinhos contemporânea. Concentrado em fazer rir, os artistas que praticam essa modalidade de expressão apresentam um tipo interessante de material. A similaridade entre essas produções autocômicas e as tiras humorísticas tradicionais desestimulam a simples exposição da intimidade e a reconstituição de eventos insignificantes do cotidiano. O que conduz a narrativa é o mote cômico, a piada, reforçando o caráter de criação da autocomicidade frente o simples relato frequentemente encontrado na autobiografia em quadrinhos. Com efeito, enquanto a matriz dos quadrinhos autobiográficos norteamericanos apresenta obras cada vez mais repetitivas e banais, a autocomicidade brasileira não apresenta sinais de cansaço. Pelo contrário, os autores que iniciaram sua produção durante a primeira década do presente século (Ricardo Coimbra, André Dahmer, Chiquinha) conseguiram revitalizar o modelo introduzido por Angeli, introduzindo um aspecto de crítica social e de costumes que se configura como uma interessante crônica dos dias atuais.

Considerando o desenvolvimento da indústria das histórias em quadrinhos no Estados Unidos, é possível interpretar a autobiografia como uma fase, um período de 
transição entre um modelo de produção mais direcionado para o mercado e a abertura para novas possibilidades de expressão. Ao mesmo tempo, esse fenômeno seria acompanhado pelo processo de aceitação social dos quadrinhos como objeto artístico. Nesse ponto, acontece uma virada interessante, já que a autobiografia, manifestação que, em sua gênese, apontava para uma maior liberdade e diversificação dos quadrinhos, torna-se um gênero cujas convenções dificultam o desenvolvimento de novas modalidades narrativas. Mais preocupados com o prestígio do que com a expansão das possibilidades formais dos quadrinhos, muitos criadores seguem a autobiografia como único caminho possível. Nesse sentido, a autobiografia representa a domesticação dos quadrinhos, sua tentativa de adequação aos padrões estabelecidos por outras manifestações culturais, principalmente a literatura. Até que o público e os criadores se cansem dessa onde de exposição da intimidade, autobiografia em quadrinhos se mantem como uma forma de expressão complexa e contraditória como a própria vida. 


\section{REFERÊNCIAS}

ALBERCA, Manuel. El pacto ambíguo y La autoficción. In MELLO, Ana Maria Lisboa de Mello (Org.). Escritas do eu: introspecção e ficção. Rio de Janeiro: 7Letras, 2013.

ALVES-MAZZOTTI, Alda Judith; GEWANDSZNAJDER, Fernando. O método nas ciências naturais e sociais: pesquisa quantitativa e qualitativa. $2^{\circ}$ ed. São Paulo: Pioneira, 1999.

ANGELI FILHO, Arnaldo. Contra todos: Entrevista. São Paulo, Revista Trip nº191. p.1020.

Entrevista. Pós Tudo: 50 anos de cultura na Ilustrada. São Paulo: Publifolha, 2008. p.204 -207

.Confissões de um cartunista. Entrevista. Revista Brasileiros, 2012. http://brasileiros.com.br/2012/03/confissoes-de-um-cartunista/

AGOStinHO, Santo. Confissões. Rio de Janeiro: Nova Fronteira, 2012. [Ed. Especial Saraiva de Bolso].

AQUINO, Maria Aparecida de. Censura, Imprensa e Estado autoritário (1968-1978): o exercício cotidiano da dominação e da resistência: O Estado de São Paulo e Movimento. Bauru: EDUSC, 1999.

ARNHEIM, Rudolf. Arte e percepção visual: uma psicologia da visão criadora. São Paulo: Pioneira, 2000. $13^{\mathrm{a}}$ ed.

. Intuição e intelecto na arte. São Paulo: Martins Fontes, 2004. $2^{\mathrm{a}}$ ed.

AUMONT, Jacques. A imagem. Campinas: Papirus, 1993.

O olho interminável: cinema e pintura. São Paulo: Cosac Naify, 2004.

AZZI, Riolando. As confissões de Santo Agostinho in AGOSTINHO, Santo. Confissões. Rio de Janeiro: Nova Fronteira, 2012. [Ed. Especial Saraiva de Bolso]. p.17-44.

BAKHTIN, Mikhail M. Estética da Criação Verbal. $3^{\text {a }}$ ed. São Paulo: Martins Fontes, 2000. 3

BARTHES, Roland et. al. Análise estrutural da narrativa. Petrópolis: Vozes, 2008.

BAUDELAIRE, Charles. Sobre a modernidade: o pintor da vida moderna. $6^{\mathrm{a}}$ ed. Rio de Janeiro: Paz e Terra, 1996.

BELO, Eduardo. Livro-reportagem. São Paulo: Contexto, 2006.

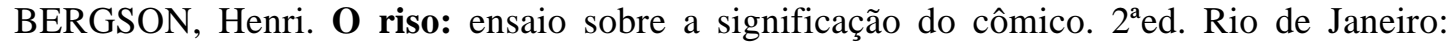
Zahar Editores, 1983.

BERNARDET, Jean-Claude. Cineastas e imagens do povo. São Paulo: Companhia das Letras, 2003. 
BEnjamin, Walter. Magia e Técnica, Arte e Política: ensaios sobre literatura e história da cultura. $8^{a}$ ed. São Paulo: Brasiliense, 2012.

BISKIND, Peter. Como a geração sexo-drogas-rock'n'roll salvou Hollywood: Easy Riders, Raging Bull. Rio de Janeiro: Intrínseca, 2009.

BRUNETTI, Ivan. A arte de quadrinizar: filosofia e prática. Tradução Marcelo Brandão Cipolla. São Paulo: Editora WMF Martins Fontes, 2013.

BÜRGER, Peter. Teoria da Vanguarda. São Paulo: Cosac e Naify, 2012.

CALVINO, Italo. Seis propostas para o próximo milênio: lições americanas. São Paulo: Companhia das letras, 1990.

CARRIÈRE, Jean-Claude. A linguagem secreta do cinema. Rio de Janeiro: Nova Fronteira, 1995.

CASTRO, Edgardo. Vocabulário de Foucault: Um percurso pelos seus temas, conceitos e autores. Belo Horizonte: Autêntica, 2009.

CHAPARRO, Manuel Carlos. Pragmática do Jornalismo: buscas práticas para uma teoria da ação jornalística. $3^{a}$ ed. São Paulo: Summus, 2007.

CHARAUDEAU, Patrick. Discurso das mídias. São Paulo: Contexto, 2009.

CHAUI, Marilena. Manifestações ideológicas do autoritarismo brasileiro. Belo Horizonte: Autêntica, 2013.

CIRNE, Moacy. A escrita dos quadrinhos. Natal: Sebo Vermelho, 2005.

Para ler os quadrinhos. $2^{\mathrm{a}}$ ed. Rio de Janeiro: Vozes, 1975.

Quadrinhos, sedução e paixão. Rio de Janeiro: Vozes, 2000.

COSTA, Carlos. A revista no Brasil do século XIX: a história da formação das publicações, do leitor e da identidade do brasileiro. São Paulo: Alameda, 2012.

CRAFTON, Donald. Before Mickey: The Animated Film 1898-1928. Cambridge: MIT Press, 1982.

CRUMB, Robert. Your vigor for life appalls me: Robert Crumb letters 1958-1977. Seattle: Fantagraphics, 2012.

DAMATTA, Roberto. Carnavais, malandros e heróis: para uma sociologia do dilema

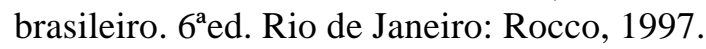

DEBRAY, Régis. Vida e morte da imagem: uma história do olhar no ocidente. Petrópolis: Vozes, 1993.

DONDIS, Donis A. Sintaxe da linguagem visual. São Paulo: Martins Fontes, 2007. $3^{\mathrm{a}}$ ed.

DORFMAN, Ariel; MARTTElaRT, Armand. $6^{\mathrm{a}}$ ed. Para ler o Pato Donald: comunicação de massa e colonialismo. Rio de Janeiro: Paz e Terra, 2010. 
DOSSE, François. O Desafio Biográfico: Escrever uma Vida. São Paulo: Editora da Universidade de São Paulo, 2009.

DUTRA, Antônio Aristides Corrêa. Jornalismo em quadrinhos: a linguagem jornalística como suporte para reportagem na obra de Joe Sacco e outros autores. 2003. 149 p. Dissertação. Escola de Comunicação da - ECO/UFRJ.

EAGLETON, Terry. Teoria da Literatura: Uma introdução. São Paulo: Martins Fontes, 2001.

ECO, Umberto. Apocalípticos e Integrados. 6ªd. São Paulo: Perspectiva, 2004. $6^{\text {a }}$ ed.

EISNER, Will. Narrativas gráficas. 2a ed. São Paulo: Devir, 2008.

ELIAS, Nobert. Mozart: sociologia de um gênio. Rio de Janeiro: Jorge Zahar, 1995.

FORTES, Leandro. Jornalismo investigativo. São Paulo: Contexto, 2007.

FORTY, Adrian. Objetos de desejo: designe e sociedade desde 1750. São Paulo: Cosac Naify, 2007.

FOUCAULT, Michel. A Arqueologia do Saber. 13ª ed.São Paulo: Loyola, 2006.

. Arqueologia das ciências e história dos sistemas de pensamento. Rio de Janeiro: Forense Universitária, 2008. $2^{\mathrm{a}}$ ed. Coleção Ditos e Escritos, vol. II.

As palavras e as coisas: uma arqueologia das ciências humanas. $9^{a}$ ed. São Paulo: Martin Fontes, 2007.

A ordem do discurso. 13 ${ }^{\text {a }}$ ed. São Paulo: Loyola, 2006.

Estética: Literatura e Pintura, Música e Cinema. Rio de Janeiro: Forense Universitária, 2009. $2^{\mathrm{a}}$ ed. Coleção Ditos e Escritos, vol. III.

História da loucura: na Idade clássica. $8^{\mathrm{a}}$ ed. São Paulo: Perspectiva, 2005.

Microfísica do Poder. 20ª ed. São Paulo: Paz e Terra, 2004.

. Vigiar e punir: nascimento da prisão. 35ª ed. Rio de Janeiro: Vozes, 2008.

FREUD, Sigmund. Os Chistes e a Sua Relação com o Inconsciente. Rio de Janeiro: Imago, 2006.

GAIR, Christopher. The American Counterculture. Edinburgh: Edinburgh University Press, 2007.

GARCÍA, Santiago. A novela gráfica. São Paulo: Martins Fontes, 2012.

GASCA, Luis; GUBERN, Roman. El discurso del comic. $2^{\text {a }}$ Ed. Madrid: Ediciones Cátedra, 1991.

GASPARI, Elio. A ditadura envergonhada. São Paulo: Companhia das Letras, 2002.

GAY, Peter. O coração desvelado: a experiência burguesa da Rainha Vitória a Freud. São Paulo: Cia das Letras, 1999. 
GIOVANNINI, Giovanni. Evolução na comunicação: do sílex a silício. $2^{\mathrm{a}}$ ed. Rio de Janeiro: Nova Fronteira, 1987.

GOFF, Jacques Le. São Luís. Rio de Janeiro: Record, 2010.

GOFFMAN, Ken; JOY, Dan. Contracultura através dos tempos: do mito de Prometeu à cultura digital. Rio de Janeiro: Ediouro, 2007.

GOMBRICH, E.H. A História da Arte. 15ª ed. Rio de Janeiro: Guanabara Koogan, 1993.

Arte e ilusão: um estudo da psicologia da representação pictórica. $4^{a}$ ed. São Paulo: Martins Fontes, 2007.

GONÇALO JÚNIOR. A Guerra dos Gibis. São Paulo: Cia das Letras, 2004.

A Morte do Grilo: A história da Editora A\&C e do gibi proibido pela ditadura militar em 1973. São Paulo: Peixe Grande, 2012.

Maria Erótica e o clamor do sexo: Imprensa, pornografia, comunismo e censura na ditadura militar 1964-1985. São Paulo: Peixe Grande, 2010.

GRAVETT, Paul. Mangá: Como o Japão Reinventou os Quadrinhos. São Paulo: Conrad, 2006.

Graphic Novels: Stories to change your life. London: Aurum Press, 2005.

GUAZZELLI, Eloar. A produção de quadrinhos no Rio Grande do Sul in SANTOS, Roberto Elísio dos; VERGUEIRO, Waldomiro (Orgs.). A história em quadrinhos no Brasil: Análise, Evolução e Mercado. São Paulo: Editora Laços, 2011. p. 113-147

HABERMAS, Jürgen. Mudança estrutural da Esfera Pública: investigações quanto a uma categoria da sociedade burguesa. $2^{\mathrm{a}}$ ed Rio de Janeiro: Tempo Brasileiro, 2003..

HANSON, Dian. The Big Butt Book. Los Angeles: Taschen, 2010.

HATFIELD, Charles. Alternative comics: an emerging literature. Mississippi: University Press of Mississippi, 2005.

HOME, Stewart. Assalto à cultura: utopia subversão guerrilha na (anti) arte do século XX. $2^{\mathrm{a}}$ ed.São Paulo: Conrad, 2004.

JACOBS, Dale. Graphics Encounters: Comics and the Sponsorship of Multimodal Literacy. New York: Bloomsbury, 2013.

JOLY, Martine. Introdução à análise da imagem. São Paulo: Papirus, 1996.

JENKINS, Henry. Cultura da convergência. São Paulo: Editora Aleph, 2008.

JONES, Gerard. Brincando de matar monstros: por que as crianças precisam de fantasia, videogames e violência de faz-de-conta. São Paulo: Conrad, 2004.

Conrad, 2006.

Homens do Amanhã: geeks, gângsteres e o nascimento dos gibis. São Paulo:

KING, Stephen. Dança macabra: O fenômeno do horror no cinema, literatura e na televisão dissecado pelo mestre do gênero. Rio de janeiro: Objetiva, 2003. 
LAGE, Nilson. A reportagem: teoria e técnica de entrevista e pesquisa jornalística. Rio de Janeiro: Record, 2001.

LEJEUNE, Philippe. O pacto autobiográfico: de Rousseau à Internet. Belo Horizonte: Editora UFMG, 2008

LIMA, Edvaldo Pereira. Páginas ampliadas: o livro-reportagem como extensão do jornalismo e da literatura. Campinas: Editora da Unicamp, 1993.

O que é livro-reportagem. São Paulo: Brasiliense, 1998.

LINS, Consuelo. O documentário de Eduardo Coutinho: televisão, cinema e vídeo. Rio de Janeiro: Jorge Zahar, 2007.

LOPES, Maria Immacolata Vassallo. Pesquisa em comunicação. $7^{\text {a }}$ ed. São Paulo: Loyola, 2003.

LOVECRAFT, H. P. O horror e sobrenatural em literatura. São Paulo: Iluminuras, 2007.

LUYTEN, Sonia Bibe. Mangá: O poder dos quadrinhos japoneses. São Paulo: Estação Liberdade, 1991.

MACHADO, Arlindo. Pré-cinemas \& pós-cinemas. $4^{\mathrm{a}}$ ed. Campinas: Papirus, 2007.

MARINGONI, Gilberto. Angelo Agostini: A imprensa ilustrada da Corte à Capital Federal 1864- 1910. São Paulo: Devir, 2010.

MARTINE, Joly. Introdução à análise da imagem. Campinas: Papirus, 1996.

MAZIÈRE, Francine. A análise do discurso: história e práticas. São Paulo: Parábola Editorial, 2007.

McCLOUD, Scott. Desvendando os quadrinhos. São Paulo: M. Books, 2005.

Reinventando os quadrinhos. São Paulo: M. Books, 2006.

MELLO, Ana Maria Lisboa de Mello (Org.). Escritas do eu: introspecção e ficção. Rio de Janeiro: 7Letras, 2013.

MELO, José Marques de. Jornalismo opinativo: gêneros opinativos no jornalismo brasileiro. $3^{\mathrm{a}}$ ed.Campos do Jordão: Mantiqueira, 2003.

Teoria do Jornalismo: Identidades Brasileiras. São Paulo: Paulus, 2006.

MINOIS, Georges. História do riso e do escárnio. São Paulo: Editora da UNESP, 2003

MOYA, Álvaro de. História da história em quadrinhos. $2^{\mathrm{a}}$ ed São Paulo: Brasiliense, 1996.

; OLIVEIRA, Reinaldo. História (dos quadrinhos) no Brasil in Shazan! $3^{\text {a }}$ ed São Paulo: Perspectiva, 1977.

Shazan! $3^{a}$ ed São Paulo: Perspectiva, 1977. 
NICHOLS, Bill. Introdução ao documentário. São Paulo: Papirus, 2005.

NICOLAU, Marcos. Tirinha: A síntese criativa de um gênero jornalístico. João Pessoa: Marca de Fantasia, 2007.

O'HARA, Craig. A filosofia do punk: mais que barulho. São Paulo: Radical Livros, 2005.

ORLANDI, Eni P. Análise de discurso: princípios e procedimentos. $7^{\mathrm{a}}$ ed Campinas: Pontes, 2007.

Discurso e leitura. $8^{\mathrm{a}}$ ed.São Paulo: Cortez, 2006.

ORWELL, George. Na pior em Paris e Londres. São Paulo: Companhia da Letras, 2006.

PAIM, Augusto Machado. Análise de estratégias discursivas na narrativa de jornalismo em quadrinhos 'Palestina: na Faixa de Gaza', de Joe Sacco. 2007. 70 p. Monografia. Centro de Ciências Sociais e Humanas, UFSM.

PATATI, Carlos; BRAGA, Carlos. Almanaque dos quadrinhos: 100 anos de mídia popular. Rio de Janeiro: Ediouro, 2006.

PÊCHEUX, Michel. Semântica e discurso: uma crítica à afirmação do óbvio. $3^{\mathrm{a}}$ ed. São Paulo: Editora da UNICAMP, 1997.

PENA, Felipe. Jornalismo literário. São Paulo: Contexto, 2009.

PIRANDELLO, Luigi. O Humorismo. In: Do teatro no teatro. São Paulo: Perspectiva, 1999. p.41-177.

PLUTARCO. Alexandre, o Grande. Rio de Janeiro: Ediouro, 2004.

.César in Vidas de César. São Paulo: Estação Liberdade, 2007.

RAMA, Angela; VERGUEIRO, Waldomiro (Org.). $3^{\text {a }}$ ed. Como usar as histórias em quadrinhos na sala de aula. São Paulo: Contexto, 2007.

RAMOS, Paulo. A leitura dos quadrinhos. São Paulo: Contexto, 2009.

2011

Faces do humor: uma aproximação entre piadas e tiras. Campinas: Zarabatana,

REIMÃO, Sandra. Repressão e Resistência: Censura a Livros na Ditadura Militar. São Paulo: Editora da Universidade de São Paulo, 2011.

RICOER, Paul. A memoria, a história, o esquecimento. Campinas: Editora da UNICAMP, 2007.

ROSENKRANZ, Patrick. Rebel Visions: The Underground Comics Revolution: 1963-1975. Seattle: Fantagraphics Books, 2002.

ROUSSEAU, Jean-Jacques. Textos autobiográficos \& outros escritos. São Paulo: Editora UNESP, 2009.

SAID, Edward W. Orientalismo: o Oriente como invenção o Ocidente. $9^{a}$ ed. São Paulo: Companhia das Letras, 2007. 
SALIBA, Elias Thomé. Raízes do Riso: a representação humorística na história brasileira da Belle Époque aos primeiros tempos do rádio. São Paulo: Companhia das Letras, 2002.

SANTAELLA, Lucia. Comunicação e pesquisa: projetos para mestrado e doutorado. São Paulo: Hacker Editores, 2001.

SANTOS, Roberto Elísio dos. Horror e cultura brasileira: a trajetória do quadrinho de terror no Brasil. In: SANTOS, Roberto Elísio dos; VERGUEIRO, Waldomiro (Orgs.). A história em quadrinhos no Brasil: Análise, Evolução e Mercado. São Paulo: Editora Laços, 2011.

Humor, crítica e erotismo nos quadrinhos dos anos 1980 e 1990 in SANTOS, Roberto Elísio dos; VERGUEIRO, Waldomiro (Orgs.). A história em quadrinhos no Brasil: Análise, Evolução e Mercado. São Paulo: Editora Laços, 2011. p.148 - 178

O humor na história em quadrinhos brasileira: Uma análise da Circo Editorial. 2004. 296 p. Tese de pós-doutorado. Escola do Comunicação e Artes - ECA-USP.

Para reler os quadrinhos Disney: linguagem, evolução e análise de HQs. São Paulo: Paulinas, 2002.

SARGEnTINI, Vanice; NAVARRO- BARBOSA, Pedro (Org). Michel Foucault e os domínios da linguagem. São Paulo: Claraluz, 2004.

SARTRE, Jean-Paul. A imaginação. Porto Alegre: L\&PM, 2008.

SATRAPI, Marjane. Persépolis. São Paulo: Companhia das Letras, 2007.

SAUSSURE, Ferdinand de. Curso de lingüística geral. $27^{\text {a }}$ ed. São Paulo: Cultrix, 2006.

SCHECHTER, Harold. Serial killers: anatomia do mal. Rio de Janeiro: DarkSide Books, 2013.

SILVEIRA, Mauro César. A batalha de Papel: A charge como arma na guerra contra o Paraguai. Florianópolis: Editora da UFSC, 2009.

SKINN, Dez. Comix: The Underground Revolution. New York: Thunder's Mouth, 2004.

STAROBINSKI, Jean. Jean-Jacques Rousseau: a transparência e o obstáculo. São Paulo: Companhia das Letras, 2011.

SOUNES, Howard. Charles Bukowski: Vida e loucuras de um velho safado. São Paulo: Editora Conrad, 2000.

SOUZA, Eneida Maria de. Janelas indiscretas: ensaios de crítica biográfica. Belo Horizonte: Editora UFMG, 2011.

SOUZA, Jorge Pedro. Teorias da notícia e do jornalismo. Chapecó: Argós, 2002.

Uma história crítica do fotojornalismo acidental. Chapecó: Grifos, 2000.

SOUZA JUNIOR. Juscelino Neco de. Imagem, narrativa e discurso da reportagem em quadrinhos de Joe Sacco. 2010. 158 p. Dissertação. Centro de Comunicação e Expressão UFSC.

SPIEGELMAN, Art. Metamaus. New York: Pantheon Books, 2011. 
STRÖMBERG, Fredrik. Black images in the comics: a visual history. Seattle: Fantagraphics Books, 2003.

THOMPSON, Hunter S.. A grande caçada aos tubarões. São Paulo: Conrad, 2004.

Hell's Angels: medo e delírio sobre duas rodas. São Paulo: Conrad, 2004.

. Medo e delírio em Las Vegas: uma jornada ao coração do sonho americano. São Paulo: Conrad, 2007.

Screwjack. São Paulo: Conrad, 2005.

TODOROV, Tzvetan. As estruturas narrativas. São Paulo: Perspectiva, 1970.

TRAQUINA, Nelson. O estudo do jornalismo no século XX. São Leopoldo: Editora Unisinos, 2001.

VERGUEIRO, Waldomiro. Chiclete com Banana de Angeli in MENDES, Toninho (Org.). Humor paulistano: a experiência da Circo Editorial 1984-1995. São Paulo: SESI-SP Editora, 2014. p. 31-59

Desenvolvimento e tendências do mercado de quadrinhos no Brasil in SANTOS, Roberto Elísio dos; VERGUEIRO, Waldomiro (Orgs.). A história em quadrinhos no Brasil: Análise, Evolução e Mercado. 3ª ed. São Paulo: Editora Laços, 2011. p.13-56

.; RAMOS, Paulo (Org.). Muito além dos quadrinhos: análise e reflexões sobre a $9^{\text {a }}$ arte. São Paulo: Devir, 2009.

Uso das HQs no ensino in RAMA, Angela; VERGUEIRO, Waldomiro. Como usas as histórias em quadrinhos na sala de aula. São Paulo: Contexto, 2012. p. 7-30.

WATT, Ian.. A ascensão do romance: estudos sobre Defoe, Richardson e Fielding. São Paulo: Companhia das Letras, 2010.

WITEK, Joseph. Comic book as history: the narrative art of Jack Jackson, Art Spiegelman, and Harvey Pekar. Mississippi: University Press of Mississippi, 1989.

WOLFE, Tom. A palavra pintada. Rio de Janeiro: Rocco, 2009. .

Os eleitos. Rio de Janeiro: Rocco, 1991.

Radical Chique e o Novo Jornalismo. São Paulo: Companhia das Letras, 2005.

XAVIER, Ismail (Org). A Experiência do cinema. Rio de Janeiro: Graal, 1984.

O Cinema brasileiro moderno. $3^{\text {a }}$ ed. São Paulo: Paz e Terra, 2001.

O discurso cinematográfico: a opacidade e a transparência. $4^{\mathrm{a}}$ ed.São Paulo: Paz e Terra, 2008.

\section{Histórias em quadrinhos}

B., Cynthia; CHIQUINHA. Bananas. Edição Independente, s/d. 24 p. 
B., David. Epiléptico. São Paulo: Conrad, 2007. Vol. 1.

Epiléptico. São Paulo: Conrad, 2008. Vol. 2.

BACKDERF, DERF. My friend Dahmer. New York: Abrams ComicArts, 2012.

BAGGE, Peter. Ódio. São Paulo: Via Lettera, 2001.

BECHDEL, Alison. Você é Minha Mãe?: Um drama em quadrinhos. São Paulo: Quadrinhos na Cia, 2013

BROWN, Chester. A Playboy. São Paulo: Conrad, 2001.

I Never Liked You. Montreal: Drawn \& Quartely, 1994.

Louis Riel: A comic-strip biography. Montreal: Drawn \& Quartely, 2011.

Pagando por sexo. São Paulo: WMF Martins Fontes, 2012.

The little man: shorts strips 1980 - 1995. Montreal: Drawn \& Quartely, 1998.

CAETO. Memória de Elefante. São Paulo: Cia das Letras, 2011.

CALLE, Ángel de la. Modotti: uma mulher do século XX. São Paulo: Conrad, 2005.

CLOWES, Daniel. Como uma Luva de Veludo moldada em Ferro. São Paulo: Conrad, 2002.

Eightball n5. Seattle: Fantagraphics Books, 1993.

COUTINHO, Laerte. Laertevisão: Coisas que não esqueci. São Paulo: Conrad, 2007.

CRUMB, Robert. A mente suja de Robert Crumb. São Paulo: Veneta, 2013.

.América. São Paulo: Conrad, 2004.

Blues. São Paulo: Conrad, 2004.

Fritz the cat. $2^{\text {a }}$ ed. São Paulo: Conrad, 2004.

Mr. Natural. São Paulo: Conrad, 2004.

Mr. Natural: vai para o hospício e outras histórias. São Paulo: Conrad, 2005.

Minha vida. São Paulo: Conrad, 2005.

Zap Comix. São Paulo: Conrad, 2003.

.The Complete Crumb Volume 1: The Early Years of Bitter Struggle. $4^{\text {a }}$ ed. Seattle: Fantagraphics Books, 2012.

.The Complete Crumb Volume 2: Some More Early Years of Bitter Struggle.. Seattle: Fantagraphics Books, 1988.

.The Complete Crumb Volume 3: Starring Fritz the Cat. $3^{\text {a }}$ ed. Seattle: Fantagraphics Books, 2004. 
.The Complete Crumb Volume 4: Mr. 1960s. Seattle: Fantagraphics Books, 1988.

.The Complete Crumb Volume 5: Happy Hippy Comix. $3^{\text {a }}$ ed. Seattle: Fantagraphics Books, 2004.

The Complete Crumb Volume 6: On the Crest of a Wave. $3^{\mathrm{a}}$ ed.Seattle: Fantagraphics Books, 2004. $\overline{1998.2^{a}}$ ed.

The Complete Crumb Volume 7: Hot'n'Heavy. Seattle: Fantagraphics Books,

. The Complete Crumb Volume 8: The Death of Fritz the Cat. Seattle: Fantagraphics Books, 1992.

The Complete Crumb Volume 9: R. Crumb versus the Sisterhood. Seattle: Fantagraphics Books, 1992.

. The Complete Crumb Volume 10: Crumb Advocates Violent Overthrow. 2 $2^{\mathrm{a}}$ ed.Seattle: Fantagraphics Books, 1997.

. The Complete Crumb Volume 11: Mr. Natural Committed to a Mental Institution. Seattle: Fantagraphics Books, 1995.

The Complete Crumb Volume 12: We're Livin;in the "Lap o' Luxury". .Seattle: Fantagraphics Books, 1997.

The Complete Crumb Volume 13: The Season of the Snoid. .Seattle: Fantagraphics Books, 1998.

The Complete Crumb Volume 14: The Early 1980s and Weirdo Magazine. Seattle: Fantagraphics Books, 2001.

. The Complete Crumb Volume 15: Featuring Mode O'Day and her Pals. Seattle: Fantagraphics Books, 2001.

. The Complete Crumb Volume 16: The Mid-1980s: More Years of Valiant Struggle.Seattle: Fantagraphics Books, 2002.

The Complete Crumb Volume 17: Cave Wimp, Mode O'Day, Aline 'N' Bob, R. Crumb Goes to the Academy Awards.. Seattle: Fantagraphics Books, 2005.

1997.

The R. Crumb Coffe Table Art Book. New York: Little, Brown and Company,

CRUMBIM, Paulo; EIKO, Cristina. Quadrinhos A2. Edição independente, s/d. 3 vol.

DELISLE, Guy. Crônicas Birmanesas. Campinas: Zarabatana Books, 2009.

Crônicas de Jesusalém. Campinas: Zarabatana Books, 2012.

. Pyongyang: Uma Viagem à Coreia do Norte. Campinas: Zarabatana Books, 2007.

. Shenzhen: Uma Viagem à China. Campinas: Zarabatana Books, 2009.

EISNER, Will. Avenida Dropsie: A Vizinhança. $2^{a}$ ed. São Paulo: Devir, 2009. 
Nova York: a vida na grande cidade. São Paulo: Companhia das Letras, 2009.

. O nome do Jogo. São Paulo: Devir, 2003.

Pequenos milagres. São Paulo: Devir, 2006.

. Um contrato com Deus \& Outras Histórias de Cortiço. São Paulo: Devir, 2007.

GREEN, Justin. Binky Brown Meets the Holy Virgin Mary. San Francisco: McSweney's Books, 2009.

GUIBERT, Emmanuel. A Guerra de Alan: as memórias do soldado Alan Igram Cope. Campinas: Zarabatana Books, 2010.

JORNAL FOLHA DE S. PAULO. São Paulo. 15 de março de 1981 a 1 de Outubro de 1984.

KLEIST, Reinhard. Castro. Porto Alegre: 8INVERSO, 2011.

. Johnny Cash: uma biografia. Porto Alegre: 8INVERSO, 2009.

MAWIL. Mas podemos continuar amigos... Campinas: Zarabatana Books, 2012.

. The band. London: Blank State Books, 2011.

PEKAR, Harvey; et al. American Splendor: The life and times of Harvey Pekar. New York: Ballantine Books, 2003.

; HASPIEL, Dean. The Quitter. New York: DC Comics, 2005.

; REMNART, JOSEPH. Harvey Pekar's Cleveland. New York: Zip Comics, 2012.

; BRABNER, Joyce. Our Cancer Year. Philadelphia: Running Press, 1994.

REVISTA CHIClETE COM BANANA. São Paulo: Circo Editorial, 1985 - 1990. 24 volumes.

REVISTA CIRCO. São Paulo, Circo Editorial, 1986 - 1988. 8 volumes.

SACCO, Joe. Derrotista. São Paulo: Conrad, 2005.

Natal com Karadzic, publicado no Brasil na coletânea Comic book: o novo quadrinho norte-americano. São Paulo: Conrad, 2000.

Palestina: na Faixa de Gaza. São Paulo: Conrad, 2003.

Palestina: uma nação ocupada. São Paulo: Conrad, 2003.

2005. Área de segurança Gorazde: a guerra na Bósnia Oriental. São Paulo: Conrad, Uma história de Sarajevo. São Paulo: Conrad, 2005.

SETH. It's a good life, if you don't weaken. Montreal: Drawn \& Quartely, 2011.

Winblendon Green: O maior colecionador de quadrinhos do mundo. Rio de Janeiro: A Bolha Editora, s/d. 
SETO, Claudio. Flores Manchadas de Sangue. São Paulo: Devir, 2009.

SIEBER, Allan. É tudo mais ou menos verdade: o jornalismo investigativo, tendencioso e ficcional de Allan Sieber. Rio de Janeiro: Desiderata, 2009. ; SIEBER, Jouralbo. Ninguém me Convidou. São Paulo: Conrad, 2010.

. Mais preto no branco. Rio de Janeiro: Desiderata, 2007.

Preto no branco. São Paulo: Conrad, 2004.

SPIEGELMAN, Art. À sombra das torres ausentes. São Paulo: Companhia das letras, 2004.

2009.

Breakdowns: Retrato do artista quando jovem! São Paulo: Companhia das letras,

Maus: a história de um sobrevivente. São Paulo: Companhia das Letras, 2005.

TOMINE, Adrian. 32 stories: The complete Optic Nerve mini-comics. Montreal: Drawn \& Quartely, 2009.

\section{Blogs e sites de cartunistas}

ANGELI FILHO, Arnaldo. http://www2.uol.com.br/angeli/

B., Cynthia. http://cynthiab.com.br/

CHIQUINHA. http://chiqsland.uol.com.br/home/

COIMBRA, Ricardo. http://vidaeobrademimmesmo.blogspot.com.br/

COUTINHO, Laerte. http://manualdominotauro.blogspot.com.br/

DAHMER, André. http://www.malvados.com.br/

ITURRUSGARAI, Adão. http://adao.blog.uol.com.br/

SIEBER, Allan. http://allansieber.blogosfera.uol.com.br/

\section{Filmes}

CRUMB. Direção: Terry Zwigoff. Produção: Terry Zwigoff e Lynn O'Donnell. Sony Pictures Classic - The Criterion Collection, 1985. Documentário, sonoro, colorido.

FRITZ THE CAT. Direção: Ralph Nakshi. Produção: Steve Krantz. Cinemation, 1972. Son, color. Animação, sonoro, colorido.

MALDITOS CARTUNISTAS. Direção: Daniel Garcia e Daniel Paiva. Produção: Daniel Garcia, Daniel Paiva, Cavi Borges e Sandra Maya. Daniéis Entretenimento, 2011. Documentário, sonoro, colorido. 